\author{
UNIVERSIDADE DE SÃO PAULO \\ INSTITUTO DE ESTUDOS BRASILEIROS \\ PROGRAMA DE PÓS-GRADUAÇÃO \\ CULTURAS E IDENTIDADES BRASILEIRAS
}

FILIPE AUGUSTO CHAMY AMORIM FERREIRA

O sonho americano de Monteiro Lobato:

relações Brasil-EUA na obra do escritor

São Paulo

2019 


\author{
UNIVERSIDADE DE SÃO PAULO \\ INSTITUTO DE ESTUDOS BRASILEIROS \\ PROGRAMA DE PÓS-GRADUAÇÃO \\ CULTURAS E IDENTIDADES BRASILEIRAS
}

\title{
O sonho americano de Monteiro Lobato: \\ relações Brasil-EUA na obra do escritor
}

\author{
Versão Corrigida \\ (Versão original encontra-se no \\ Instituto de Estudos Brasileiros)
}

FILIPE AUGUSTO CHAMY AMORIM FERREIRA

Dissertação apresentada ao Programa de Pós-Graduação Culturas e Identidades Brasileiras do Instituto de Estudos Brasileiros da Universidade de São Paulo, para a obtenção do título de Mestre em Filosofia

Área de concentração: Estudos Brasileiros

Orientador: Prof. Dr. Fernando Paixão

São Paulo 
DADOS DE CATALOGAÇÃO NA PUBLICAÇÃO (CIP)

Serviço de Biblioteca e Documentação do

Instituto de Estudos Brasileiros da Universidade de São Paulo

(c) reprodução total

F383

Ferreira, Filipe Augusto Chamy Amorim

O sonho americano de Monteiro Lobato : relações Brasil-EUA na obra do escritor / Filipe Augusto Chamy Amorim Ferreira ; Fernando Paixão, orientador -- São Paulo, 2019.

Dissertação (Mestrado) - Universidade de São Paulo. Instituto de Estudos Brasileiros. Programa de Pós-Graduação em Culturas e Identidades Brasileiras. Area de concentração: Estudos Brasileiros. Linha de pesquisa: Brasil: a realidade da criação, a criação da realidade.

Título em inglês: Monteiro Lobato's American dream : rapports BrazilAmerica on the writer's books - São Paulo, SP.

Descritores: 1. Lobato, Monteiro, 1882-1948 2. Literatura brasileira 3. Retórica 4. Literatura infantojuvenil 5. Desenvolvimento econômico 6. Eficiência industrial 7. Progresso I. Universidade de São Paulo. Instituto de Estudos Brasileiros. Programa de Pós-Graduação II. Paixão, Fernando, orient. III. Título. 
NOME: FERREIRA, Filipe Augusto Chamy Amorim (filipechamy@ yahoo.com.br)

Título: O sonho americano de Monteiro Lobato: relações Brasil-EUA na obra do escritor

Dissertação apresentada ao Programa de Pós-Graduação Culturas e Identidades Brasileiras do Instituto de Estudos Brasileiros da Universidade de São Paulo, para a obtenção do título de Mestre em Filosofia

Aprovado em:

Banca examinadora:

Prof. Dr. $\quad$ Fernando Paixão

Instituição: $\quad$ Universidade de São Paulo

Julgamento:

Profa. Dra. Marisa Philbert Lajolo

Instituição: Universidade Presbiteriana Mackenzie

Julgamento:

Prof. Dr. João Luís Cardoso Tápias Ceccantini

Instituição: $\quad \underline{\text { Universidade Estadual Paulista Júlio de Mesquita Filho }}$

Julgamento:

Prof. Dr. Luís Hellmeister de Camargo

Instituição: Universidade Estadual de Campinas

Julgamento: 


\section{ÍNDICE}

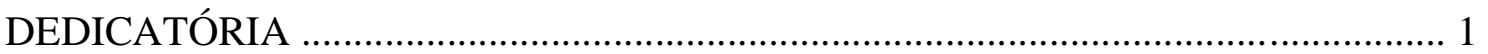

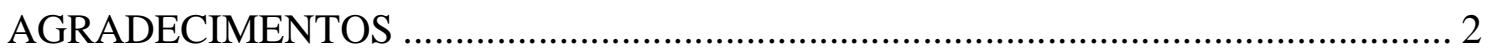

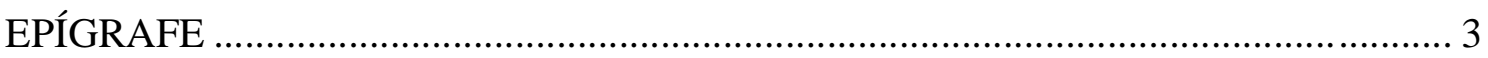

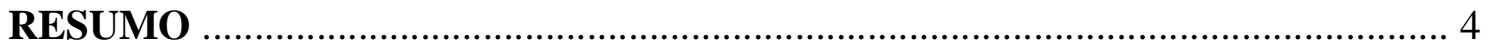

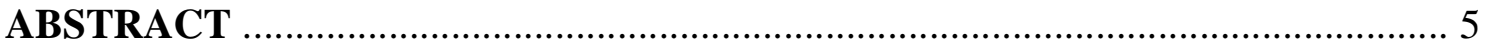

1. MONTEIRO LOBATO E OS ESTADOS UNIDOS ........................................ 6

1.1. A TRILOGIA AMERICANA DE MONTEIRO LOBATO: FEIÇÕES, LIMITES E

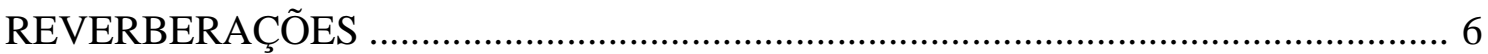

1.2. SURGIMENTO DA “AMERICANOFILIA": PENDORES FRANCESES X O

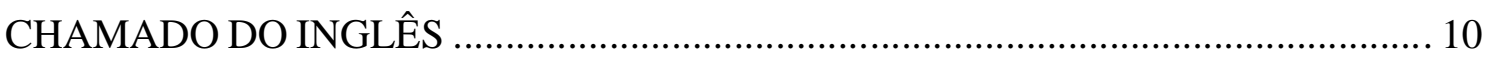

1.3. HENRY FORD, O MESSIAS DE UMA NOVA ERA …........................................ 17

2. O PRESIDENTE NEGRO OU LOBATO SONHA A AMÉRICA …................... 24

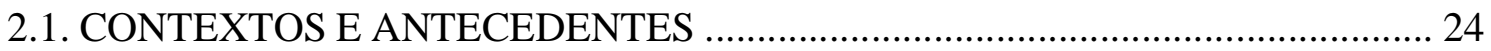

2.2. UM LIVRO BRASILEIRO PARA OS ESTADOS UNIDOS ................................. 27

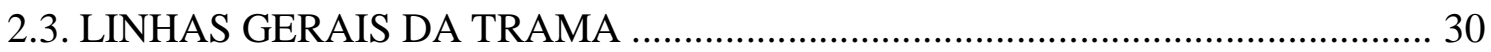

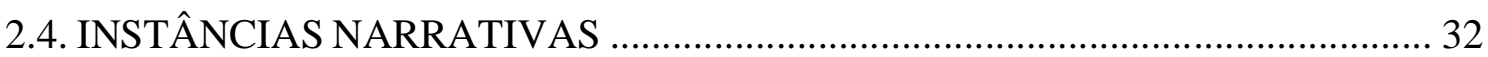

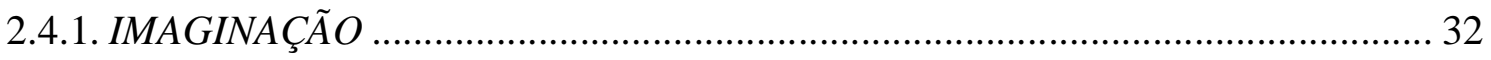

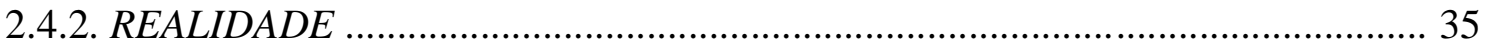

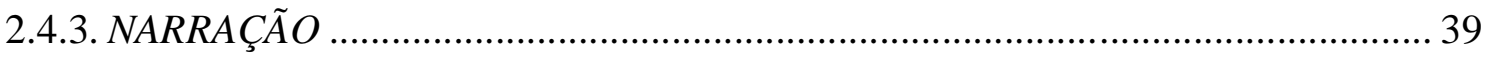

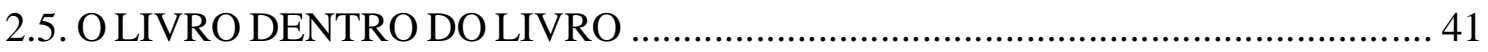

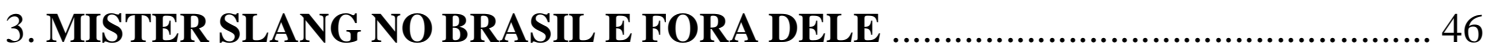

3.1. UM PAÍS A SER MUDADO DE DENTRO PARA FORA: MISTER SLANG E O

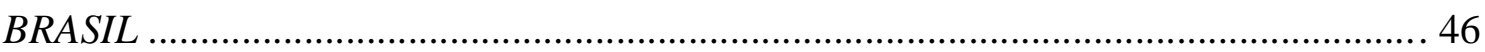

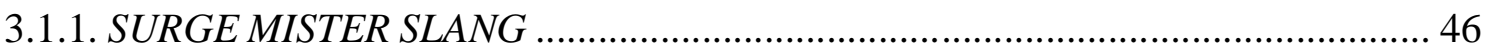

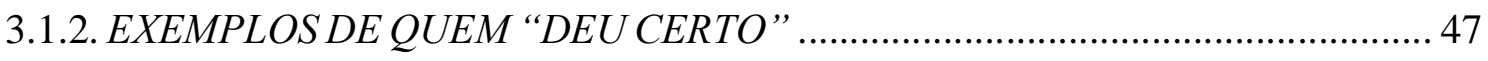

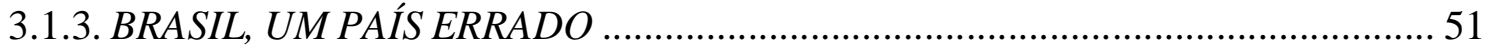

3.2. LOBATO TURISTA AMERICANO OU MR. SLANG ABROAD: AMÉRICA ...... 57

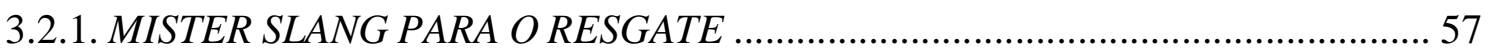

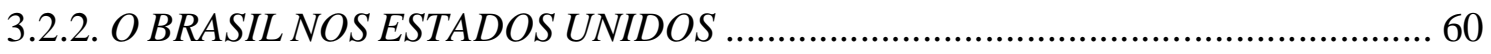

3.2.3. A AMÉRICA CRITICADA OU UMA CHECAGEM EMPÍRICA DOS ESTADOS

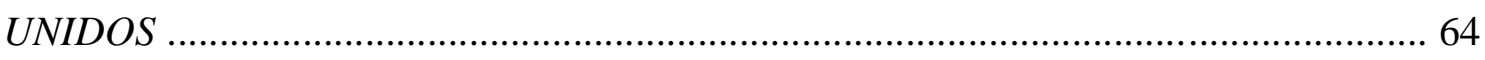

4. AS IDEIAS AMERICANAS RESSURGIDAS NOS LIVROS INFANTIS ......... 75 
4.1. AVENTURAS “COM O PÉ NO CHÃO”: OS PARADIDÁTICOS .75

4.2. PERSONAGENS, ABORDAGENS E RESULTADOS 81

4.3. COMPARATIVO ENTRE A RETÓRICA DAS PERSONAGENS ADULTAS E INFANTIS .90

Figura 1 91

5. PANORÂMICA DA TRILOGIA AMERICANA LOBATIANA .96

5.1. A RETÓRICA DO CONVENCIMENTO E AS INSTÂNCIAS DA TRILOGIA AMERICANA .96

5.2. O AVATAR LOBATIANO ADULTO, SEMELHANÇAS E ABORDAGENS .... 98

5.2.1. PERDA DA COLOQUIALIDADE . 99

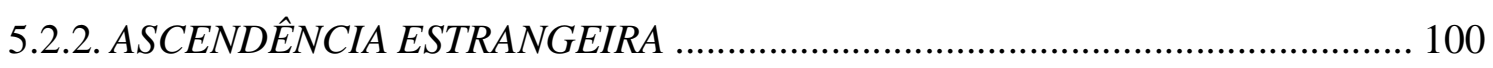

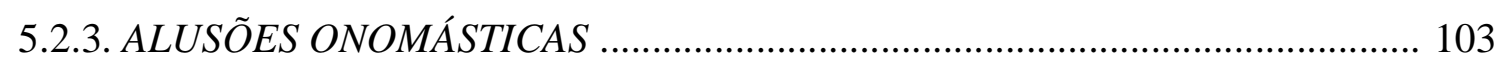

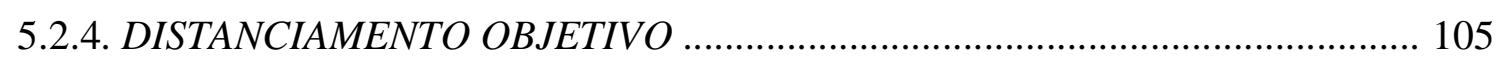

5.2.5. O FASCÍNIO DOS ESTRANGEIROS ……………………..................................... 109

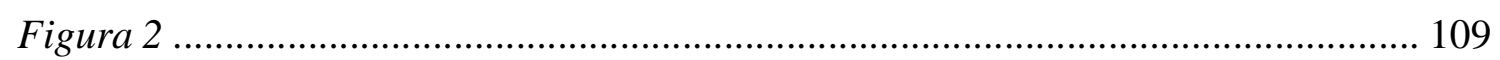

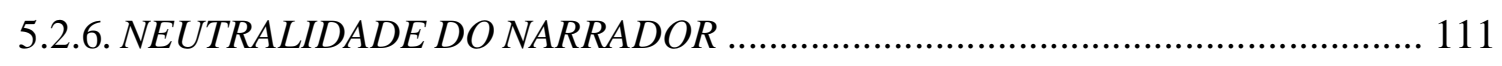

6. CONCluSÃO: ANÁliSE CRÍTICA DOS RESUltadoS DOS LIVROS

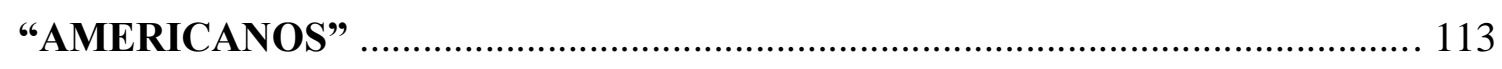

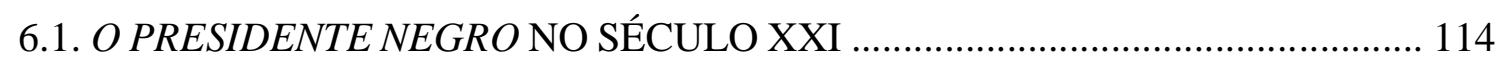

5.3.2. IMEDIATISMO E PERENIDADE EM MISTER SLANG E O BRASIL .............. 120

5.3.3. "NOVA DOUTRINA MONROE” OU AMÉRICA PARA OS BRASILEIROS . 122

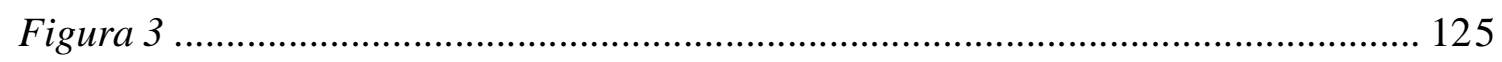

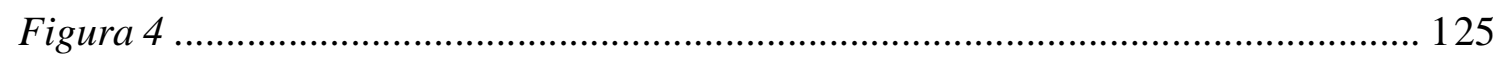

5.3.4. UMA IDEIA QUE "DEU CERTO”: OS LIVROS INFANTIS ……………….... 126

BIBLIOGRAFIA CONSULTADA E REFERENCIADA ...................................... 131

ANEXO 1. AS "IDEIAS AMERICANAS" NAS OBRAS ADULTAS E INFANTIS:

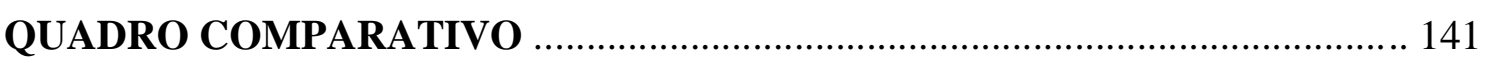

ANEXO 2. LOBATO, MÁRIO DE ANDRADE E O MODERNISMO: TENSÕES

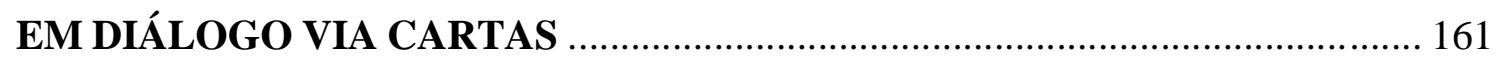
ANEXO 3. CARTAS E CORRESPONDÊNCIAS COLETADAS NOS ACERVOS DO IEB, UNICAMP E BIBLIOTECA MONTEIRO LOBATO 169 
Para Mozart, Paganini, Bach, Hilary Hahn e Jon Lord, principais e valiosas companhias durante as horas de redação.

E aos reformadores da natureza. 
Tenho muitos a quem agradecer. Aqui vão alguns deles; a lista é apenas exemplificativa:

Elisabete Marin Ribas, quem primeiro me direcionou ao material de Lobato no arquivo IEB-USP.

Fernando Paixão, meu orientador, que aprovou a mudança de rumo na minha pesquisa, originalmente sobre Rachel de Queiroz, e sugeriu o enfoque americano.

Patricia Tavares Raffaini, parceira lobatista, pelos avisos e conselhos. O solícito pessoal dos acervos de pesquisa: Aníbal, do CEDAE da Unicamp; Adriano, Mariana e Denise, do IEB; Antônio, da Biblioteca Monteiro Lobato.

Marcos Antonio de Moraes, Marisa Lajolo, João Luís Ceccantini e Luís Camargo, pelas gentis dicas de bibliografia.

Os colegas que me deram sugestões de leitura: Matheus, Lucas, Celbi, Marlon, Mariana, Luiz, Cristiane, Fábio.

Heitor, baluarte de Troia, pela confirmação das palavras de Píndaro.

A família, que de algum modo aceitou que eu precisava de tempo, espaço e concentração.

Os amigos, que me deram suporte emocional e momentos de alegria: Yuli, Fernando, George, Daniel, Lúcia, Gabriela, Lucas, André, Lais, Larissa, Carlos, Pâmella, Vinicius, Linara, Beatriz, Valério, Rômulo, entre outros.

A brava namorada Patricia, que testemunhou e serenou vários dos meus altos e baixos nesses atribulados dois anos.

E Monteiro Lobato, inesgotável fonte de inspiração e exemplo perservarante. 
Torna-te o que aprendeste que és.

Píndaro 


\section{RESUMO}

FERREIRA, Filipe Augusto Chamy Amorim. O sonho americano de Monteiro Lobato: relações Brasil-EUA na obra do escritor. 2019. 196 páginas. Dissertação (Mestrado em Filosofia) - Instituto de Estudos Brasileiros, Universidade de São Paulo, São Paulo, 2019.

José Bento Monteiro Lobato (1882-1948) notabilizou-se em muitas atividades. No governo de Washington Luís, foi nomeado Adido Comercial nos Estados Unidos e para lá se mudou com a família (1927-31). As ideias relacionadas ao "desenvolvimentismo" de Henry Ford corriam mundo. Lobato, tradutor e admirador de Ford, começa então um projeto de aproximação literário-ideológica com o fordismo e, mais amplamente, com a organização social e econômica dos Estados Unidos. Nessa conjuntura, escreve livros em que expõe suas ideias: $O$ choque das raças (ou $O$ presidente negro), romance, e duas obras acerca de um curioso personagem (Mister Slang), que têm por título Mister Slang e o Brasil, publicada em 1926-7, e América, de 1932. A passagem de Lobato pelos Estados Unidos é "emoldurada" pelas reflexões de Mister Slang. Do que observou e ponderou na viagem, Lobato arregimentou argumentos que o levariam a pregar o aperfeiçoamento da siderurgia brasileira e o aproveitamento dos recursos naturais por parte do governo, em obras como $O$ escândalo do petróleo e Ferro. Também em sua obra para crianças as "ideias americanas" se mostrariam fortes e presentes, muitas vezes aparecendo quase sob a mesma forma que nas obras para adultos, com uma peculiar utilização do discurso político remodelado para suas personagens infantis. Este trabalho pretende analisá-las com a devida contextualização e aprofundamento. O viés metodológico será internalista, com atenção fundamental aos textos lobatianos em suas duas dicções essenciais: aos adultos, em livros e jornais, e às crianças, por meio dos célebres personagens do Sítio do Picapau Amarelo. As hipóteses a analisar são concernentes à abordagem retórica, efeitos e estilo das duas dicções, comparativamente. Coincidências, disparidades e semelhanças serão dissecadas.

Palavras-chave: literatura brasileira; retórica; eficiência industrial; progresso; literatura infanto-juvenil; desenvolvimento econômico. 


\section{ABSTRACT}

FERREIRA, Filipe Augusto Chamy Amorim. Monteiro Lobato's American dream: rapports Brazil-America on the writer's books. 2019. 196 pages. Dissertation (Masters in Philosophy) - Brazilian Studies Institute, Universidade of São Paulo, São Paulo, 2019.

José Bento Monteiro Lobato (1882-1948) distinguished himself over many activities. On the Washington Luís administration, he was nominated Commercial Attaché to the United States of America and moved with his family (1927-31). Henry Ford's progress-related ideas ran worldwide. Lobato, a Ford translator and admirer, began, in literature as well as in ideology, to get close to fordism and to America's social and economic structures. On this context, he wrote books to share his thoughts: the novel The racial struggle (or The black president) and two volumes featuring a curious character (a Mister Slang), entitled Mister Slang and Brazil, published over 1926-7, and America, released in 1932. Lobato's stay over US is "framed" by Mister Slang's reflexions. From what he observed and considered throughout the travel, Lobato gathered arguments that would led him to claim for the improvement of Brazilian steel industry as well as for the adequate natural resources exploration by the government, in works such as The petroleum scandal and Iron. His books for children also featured strong and powerful "American ideas", that many times appeared almost on the same form of his adult works, with a peculiar utilization of a reshaped political discourse by his characters for children. This work intents to analyze it with due focus and depth. The methodological approach will be an internal one, with great care for the author's texts on two different records of speech: aiming the adult public, by means of vehiculation on newspapers and magazines, and the childish audience, with the aid of the famous Yellow Woodpecker Ranch characters. The hypothesis is to verify concern rethorical formulations, effects and style on diverse utterances, confronted. Coincidences, disparities and similarities shall be analyzed.

Keywords: Brazilian literature; rhetorics; industrial efficiency; progress; children literature; economical development. 


\section{MONTEIRO LOBATO E OS ESTADOS UNIDOS}

\subsection{A TRILOGIA AMERICANA DE MONTEIRO LOBATO: FEIÇÕES, LIMITES E REVERBERAÇÕES}

A relação de Monteiro Lobato com os Estados Unidos é assunto vasto e que pode gerar por si inúmeras considerações e especulações, ao longo de toda a vida e produção do escritor. Pode-se falar que uma "americanofilia" desenvolveu-se paralelamente a sua produção de escritor, ao longo de suas três décadas de atividade editorial - considerando de $O$ saci-pererê: resultado de um inquérito e Urupês, seus primeiros livros, publicados em 1918, a todas as demais obras até sua morte em 1948.

Tarefa titânica e algo inócua procurar "explicar" um homem por sua obra. O caso de Lobato, todavia, como o próprio homem, é paradoxalmente revelador. Se é verdade que organizar a produção de alguém e com isso tentar dimensionar todas as suas facetas é missão frustrante, que incorreria no que Pierre Bourdieu muito adequadamente chamou de ilusão biográfica - "Tentar compreender uma vida como uma série única e, por si só, suficiente de acontecimentos sucessivos, sem outra ligação que a vinculação a um "sujeito" (...), é quase tão absurdo quanto tentar explicar um trajeto no metrô sem levar em conta a estrutura da rede" (1997: 81) -, não é menos verdade que Monteiro Lobato usou sua obra essencialmente para falar dos problemas que diziam respeito a seu pensamento, seus credos e seus ideais.

Daí encontrarmos tanto de Lobato nela. Quando suas personagens clamam algo, o assunto lhe interessa; quando seus livros têm um mote específico (como divulgar tecnologia ou comentar a cena política), as idiossincrasias do escritor se fazem ver. $\mathrm{O}$ alerta de Bourdieu deve se fazer presente nos critérios de análise de um corpo de obra frente aos elementos da vida do autor. No entanto, não se deve pressupor que vida e obra jamais se interseccionam - imaginar uma situação assim seria quase retirar o que de orgânico há na produção do conhecimento humano e suas formas de expressão e veiculação.

Às vezes torna-se difícil separar o escritor e sua obra. Lobato frequentemente usava avatares ${ }^{1}$ bastante evidentes. Personagens que diziam as mesmas coisas que ele repetia em entrevistas e artigos. Relatos que tinham a ver com experiências que ele mesmo

\footnotetext{
${ }^{1}$ Como definido no Caldas Aulete: "Processo e resultado de transformação, metamorfose, transfiguração; o; TRANSFIGURAÇÃO: Aquele personagem de Shakespeare foi o avatar do ator” (2019).
} 
vivenciou. Discutiremos ao longo deste trabalho como se dão as operações para viabilizar tais avatares e o que isso representa no desenvolvimento do pensamento lobatiano.

Nem sempre o processo se dá de maneira tão cristalina, contudo. Pode-se indagar se aqui ou ali é Lobato quem prega ou uma sua personagem se rebela ao controle. Emília, por exemplo: a ex-boneca, que virou uma menina real nos livros tardios do escritor ${ }^{2}$ e que representa, na opinião de todos os estudiosos lobatianos e do próprio autor, sua maior expressão iconoclasta. "[Emília é] Tão independente que nem eu, seu pai, consigo dominá-la. (...) Cada vez mais, Emília é o que quer ser, e não o que eu quero que ela seja. Fez de mim um 'aparelho', como se diz em linguagem espírita” (2010a: 551). Porém o quanto do que Emília diz pode ser imputado a Lobato? E Dona Benta? E suas outras personagens?

A obra adulta lobatiana, ou "literatura geral" (como consta em suas Obras Completas, organizadas por Lobato a partir de 1946 para a Editora Brasiliense), apresenta diversos pontos importantes para a compreensão das matérias pertinentes ao projeto autoral-expressivo do escritor, ainda que sem dúvida seja hoje menos conhecida e lida que a infantil, e com bem menos edições e relançamentos - como aliás já o era na época de Lobato, que afirmou em 1944:

\begin{abstract}
"Meus livros saem muito mais nos meios infantis que nos adultos. No total das minhas tiragens até fim do ano passado o livro para crianças entrava por dois terços - oitocentos mil em 1,2 milhão. E este ano a porcentagem recresce mais ainda: dos 340 mil exemplares já saídos e a saírem aqui e na Argentina, só haverá uns vinte mil para adultos" (2009c: 185).
\end{abstract}

\footnotetext{
${ }^{2}$ Apesar de celebrizada na memória do público (sobretudo o da segunda metade do século XX em diante, por força das adaptações para outras mídias, como televisão e teatro) como uma eterna boneca de pano, Emília, no decorrer das histórias de Lobato, vira uma menina de verdade. A despeito de as histórias com a turma do Sítio não seguirem especificamente um plano rigidamente fixo nas Obras Completas organizadas por seu autor (exemplo: em A reforma da natureza é mencionada A chave do tamanho, aventura posterior), a partir de um certo ponto Emília passa a ser referenciada explicitamente como ex-boneca. Ela mesma explica a mudança em $A$ chave do tamanho: “(...) E eu sou a 'evolução gental' daquela bonequinha pernóstica. (...) Artes do mistério. Fui virando gentinha e gente sou; belisco-me e sinto a dor da carne. E também como" (1988a: 151). Não percamos de vista, contudo, que, ainda que tenha virado uma menina nas histórias, Emília constitui-se, importa notar e refletir, numa personagem, o que implica construções propostas e designadas por um autor. Curiosamente, é o Pequeno Polegar quem explica, numa das Histórias diversas (o último livro da série infantil de Lobato nas suas Obras Completas, com histórias organizadas postumamente), as particularidades de ser personagem e não ficar velho: "Pertenço à turma dos 'personagens'. Envelhecem vocês, gente; os 'personagens', não. Peter Pan, Emília, o Gato de Botas, Capinha Vermelha, a Gata Borralheira, todos nós não somos gente, somos 'personagens"' (1988e: 195). Ainda no mesmo livro, uma personagem não nomeada pergunta a diferença entre gente e personagem, $\mathrm{e}$ outra personagem, igualmente sem identificação, responde: "Gente é gente, você sabe, não preciso explicar. E personagem é uma coisa muito mais que gente, porque gente morre e os personagens não morrem, são imortais, eternos" (1988e: 242).
} 
Menos "centrada" que a infantil, que quase sempre era publicada já originariamente em forma de volumes (livros fechados), a obra adulta de Monteiro Lobato pulveriza-se em dezenas de contos, centenas de artigos, um romance, incontáveis críticas, cartas, entrevistas, panfletos, conferências, obras híbridas e de difícil rotulagem.

A análise dessa enorme massa bibliográfica não é simples e não pretendemos esgotá-la. Nosso recorte é específico: analisaremos essencialmente o que chamaremos doravante de "trilogia americana" de Monteiro Lobato, composta pelas obras $O$ presidente negro (1926), Mister Slang e o Brasil (1927) e América (1932), bem como os reflexos tardios dessas ideias em sua produção literária infantil, que Lobato tinha como sua obra definitiva: “Com as tiragens deste ano passo o milhão só de livros infantis. Esse número demonstra que meu caminho é esse - e é o caminho da salvação. (...) Estou nesse setor há já vinte anos, e o intenso grau da minha 'reeditabilidade' mostra que o meu verdadeiro setor é esse" (2010a: 554-5).

Explica-se o recorte proposto com as seguintes considerações: são os três livros da bibliografia lobatiana inteiramente (ou majoritariamente) dedicados aos problemas dos Estados Unidos da América. Comportam considerações sobre sua cultura, política e organização social - e, sobretudo, a apologia do progresso e da eficiência, noções caras ao povo americano, na visão de Lobato, e que igualmente o fascinavam.

De todas as suas Obras Completas, apenas essas três tratam, na totalidade, dos métodos e sistemas americanos. Publicadas entre o meio dos anos 1920 e o começo da década de 1930, representam um momento importante e crucial na biografia e na carreira do escritor e também na história política e socioeconômica do Brasil. São os anos que antecedem e testemunham sua ida aos Estados Unidos, como adido comercial do Brasil no país ianque, e durante os quais o escritor se aproxima da atividade empresarial, com vistas à exploração do ferro e do petróleo, o que depois traria reflexos importantes em suas campanhas em solo brasileiro.

Importante ressaltar que são anos de mudanças estruturais cruciais no cenário brasileiro: com os fluxos migratórios, temos uma população repleta de estrangeiros, trazendo diversidade de línguas, saberes, hábitos culturais, conflitos; a facilidade das novas comunicações (rádio, cinema) trazia modas, ditava comportamentos e tendências; a industrialização avançava virtualmente no mundo todo, com inspiração massiva num grande ídolo de Lobato: Henry Ford.

Lobato admirava Ford e pode-se imputar a ele, em boa parte, a chegada das ideias do industrial americano em terras brasileiras. Traduziu suas obras, difundiu seu 
pensamento nos livros veiculados ao público brasileiro e chegou a visitar suas indústrias sediadas no solo americano. Também faz parte do escopo deste trabalho analisar a influência de Ford sobre Lobato e o exemplo que o escritor brasileiro tirava dos "grandes homens" de ação, políticos americanos ou pioneiros que admirava e seguia.

Portanto, estamos diante de um recorte específico, compreendido entre 1926 (ano de $O$ presidente negro) e 1932 (publicação de América). Janela que merece destaque em qualquer estudo sobre Monteiro Lobato, pois trata de uma nova dinâmica na obra do escritor, com procedimentos e abordagens que visam a fins específicos, o que também discutiremos.

A trilogia americana comprova que Lobato queria chegar ao mercado consumidor americano e intentava importar para o Brasil os "bons exemplos" que enxergava na nação americana. Importante anotar o empirismo envolvido no método, pois o começo da trilogia se dá em uma obra ficcional, quando o escritor "sonhava" a América de um ponto de vista algo distante, e termina com um relato só possível por quem lá esteve, tomou parte na ação e tirou conclusões com mais facetas - inclusive negativas - do que uma pessoa que apenas “ouviu dizer".

Um ponto de destaque em nosso estudo é seu capítulo sobre os "ecos" da trilogia americana na obra infantil de Lobato. Como dissemos, o escopo mor do trabalho é a trilogia e seu contexto histórico-cultural para Lobato, o Brasil e o mundo; no entanto, poucos anos depois Lobato estaria dizendo as mesmas coisas nas obras destinadas a seus leitores mirins. Esse fenômeno suscita investigação, não sendo obviamente uma casualidade. O que dos americanos as crianças precisam saber? De que modo? Em que livros isso será veiculado, e sob que tratamento, com que intuitos?

Também de se notar que várias convicções que o escritor adquiriu nos Estados Unidos eventualmente virariam princípios relevantes em suas atividades de empresário, publicista e escritor. "O ferro para construir as máquinas, o petróleo para movimentá-las", base das campanhas famosas que lhe trariam divulgação, admiradores, prisões, desgostos e alegrias.

Seus livros Ferro, O escândalo do petróleo e $O$ poço do Visconde são posteriores a seus "anos americanos"; no entanto, devem à trilogia americana sua razão de existir, os germes de inconformismo que resultariam na confecção desses libelos contra a ineficácia do Estado brasileiro e a favor do aproveitamento dos recursos que engrandeceram os americanos, na visão fundamentada de Lobato. 
Fundamentada e empírica: ele lá esteve, observou e concluiu que os métodos dos americanos funcionavam, podendo ser importados por nós brasileiros. O escritor diria em Ferro, acerca de soluções para a problemática do aproveitamento de energia: "Serão tambem soluções americanas, porque é na America, não aqui, que as reais soluções dos nossos problemas estão sendo achadas" (1951c: 298). Oportuno esclarecer neste ponto que, por razões instrumentais e de fidelidade ao texto referenciado, optou-se por manter ao longo desta dissertação a ortografia original das edições consultadas.

Quando Lobato fala de novos métodos e procedimentos para produção de ferro, por exemplo, estabelece sem hesitação que esse novo ponto de observação se viabilizou porque "pude acompanhar a evolução desse processo durante os quatro anos que residi na America do Norte (...). [Os artigos que publicou sobre o assunto] Significam, pois, um testemunho muito sincero e muito ponderado do que vi, ouvi e aprendi” (1951c: 243).

A questão da "empolgação" lobatiana, que comporta ao mesmo tempo empreendedorismo e boa dose de ingenuidade, também será por nós comentada. Importa compreender que, com o distanciamento de que hoje dispomos, podemos entender os pontos controversos da pregação lobatiana: métodos que já foram testados e falharam, pontos concluídos de modo equivocado na argumentação do escritor e problemas equiparados.

A trilogia americana, destarte, apresenta ideias que Lobato experimentou e pensou por bem "fixar". Não todas; discutiremos o que da trilogia ficou e o que se perdeu. É imprescindível, contudo, estabelecer a coerência do "projeto americano" lobatiano - o que se verifica em toda sua produção daí em diante, com efeitos que exploraremos no decorrer deste trabalho.

\subsection{SURGIMENTO DA “AMERICANOFILIA": PENDORES FRANCESES X O CHAMADO DO INGLÊS}

Em suas obras, cartas e entrevistas, Lobato frequentemente demonstrou apreço pela organização político-social dos americanos, sua cultura e pensamento industrial. Como assenta Milena Ribeiro Martins,

\footnotetext{
"As experiências e impressões de Lobato sobre os Estados Unidos aparecem numa variedade de textos relativos a esse período: são cartas pessoais e profissionais, enviadas a familiares e amigos; relatórios e documentos profissionais, produzidos no âmbito do serviço consular; e por fim o texto híbrido de América" (2017: 25).
} 
O período ao qual a pesquisadora se refere, ainda que difícil de ser entendido como uma época exclusivamente específica da trajetória do autor, diz respeito ao que ora abarcamos: os anos de sua trilogia americana, que compreendem sua atuação como adido comercial nos Estados Unidos, sua viagem e estada naquela terra, a movimentação literária e ideológica correspondente.

No contexto dos primeiros anos da república brasileira, no final do século XIX e começos do XX, a influência anglófila ainda era incipiente em nossa literatura e os círculos eruditos voltavam-se mais intensamente aos valores franceses. Jeffrey D. Needell comenta em detalhes as causas, motivações e decorrências dessa francofilia nos círculos literários e eruditos brasileiros em seu aprofundado ensaio Belle Époque tropical, do qual retiramos um excerto elucidativo:

\footnotetext{
"É bom ter em mente o quanto a educação da elite era literária e francesa. Além disso (...), o peso cumulativo da tradição francófila no Rio só aumentou no decorrer do século [XIX para o XX]. Em 1900, a elite já incorporara ao cotidiano o uso do francês e a familiaridade com a cultura francesa. Muitas mulheres de elite liam a literatura francesa; muitos homens da elite também o faziam. Na verdade, vários literatos escreviam e alguns até pensavam naquela língua. Quando liam obras de autores ingleses e alemães, os brasileiros em geral o faziam em traduções francesas. (...)

Pode-se acrescentar à influência da educação, da tradição e da moda o impacto da imprensa e do comércio livreiro. Os editores, tipógrafos e livreiros cariocas eram em sua maioria franceses. Naturalmente, promoviam em suas lojas obras e periódicos franceses, da mesma forma que promoviam o estilo francês nos periódicos cariocas, no que se refere a formato, ilustrações e conteúdo. Tais locais, muito mais do que as viagens realizadas pelos membros da elite, também explicam como os brasileiros se mantinham a par das tendências literárias francesas: os estabelecimentos de Garnier e Briguiet eram a ligação vital com a Paris literária" (1993: 230-1).
}

Lobato estava nesse meio: neto de José Francisco Monteiro (1830-1911), tornado Visconde de Tremembé em 1887, cidadão de propriedades e influência política-Edgard Cavalheiro aponta que "uma das cenas de que [Lobato] guardou viva memória [da infância] foi a da última visita de Pedro II à Província de São Paulo, quando o Imperador se hospedou na casa do avô" (1955: 23) -, igualmente esteve o jovem exposto a uma educação "afrancesada", o que se pode verificar muito facilmente por suas cartas e leituras.

Tendo crescido nesse ambiente de livrarias abarrotadas de livros e autores franceses, inclusive indiretamente (via tradução), vemos o incipiente escritor às voltas, em sua juventude, com as marcas da influência francesa por todos os cantos do Brasil que 
habitava. Uma marca importante: em 1897, quando Lobato contava quinze anos, fundase a Academia Brasileira de Letras, de clara inspiração galicista ${ }^{3}$.

O próprio Lobato consumiu por então, e avidamente, livros franceses ou traduções para o francês. Alguns anos adiante, porém, o quadro seria revertido, e o escritor figuraria como um dos primeiros intelectuais do Brasil a denunciar no começo do século $\mathrm{XX}$ a passividade com que as ideias francesas eram acatadas em nossas letras ${ }^{4}$.

Observemos a distinção que Lobato faz entre duas tendências que, segundo ele, dividiam o Brasil em duas culturas:

\begin{abstract}
“(...) ficamos a imaginar que neste país de duas 'culturas' tão diversas, a letrada e a iletrada, talvez seja a iletrada a mais interessante, a mais original, a mais rica em poesia. Pelo menos a poesia que nela existe é local, inédita, nascida aqui mesmo como os musgos, as avencas, as orelhas-de-pau. A outra cultura é, e sempre foi, de importação. Importou no começo a arte e a poesia do 'reino'; depois importou-as da França; depois passou a recebê-las do mundo inteiro; e quando nasceu por lá a bobagem do Marinetti, nossa culturinha litorânea, bobinha, bobinha, começou a marinetizar - e até hoje anda nisso em vários setores, como no da pintura, sem jamais conseguir que ninguém se interesse pelo que o jeca chama "porcaria"' (2009c: 50).
\end{abstract}

Para Lobato, “importar” cultura da França configura-se um modismo, descartável e passageiro, que nada tem de substancioso para a afirmação de nossa identidade: nossa gente (os "jecas") nada entende dessa cultura "letrada" e se distancia assim das "porcarias" que identifica. Reparemos como os modismos são, por força de sua natureza, temporários: primeiro importamos a arte portuguesa, provida por nossos colonizadores; depois, voltamo-nos para a França, e depois abrimo-nos para receber influências de Marinetti e do mundo todo - menos do nosso país.

O depoimento ora transcrito encontra-se em prefácio escrito para um livro de José Bento de Oliveira publicado em 1947. Pela proximidade com sua data de falecimento, não se pode chamar de absurda a conclusão de que Lobato até o fim foi crítico aos valores "de importação" trazidos sem crítica e aprofundamento de terras estrangeiras, considerando usualmente a França a principal e mais pernóstica influência na

\footnotetext{
${ }^{3}$ Fundada por Machado de Assis (1839-1908), a ABL foi baseada em nítida influência francesa: no arranjo dos membros, na proposta organizacional e no espírito de clube a reunir a nata erudita dos campos de saber valorizados pela elite de então.

4 Ainda na geração posterior a Lobato a tendência francesa continuava presente num "inconsciente intelectual" fortemente enraizado em nosso país. Carlos Drummond de Andrade, em carta a Mário de Andrade em 1924, confessava-se "acidentalmente brasileiro (...). Detesto o Brasil como a um ambiente hostil à expansão do meu espírito. Sou hereditariamente europeu, ou antes: francês. Amo a França como um ambiente propício, etc" (2003: 59).
} 
intelectualidade brasileira e fazendo a apologia de quem se distanciava dessa cultura "letrada"5.

Também se torna pertinente, nesse contexto, complementar a visão crítica que Lobato faz dos valores franceses acrescentando este depoimento que o autor fez em um artigo sobre o britânico Rudyard Kipling, que grandemente admirava - Cavalheiro: "Kipling abrira-lhe o reino encantado da literatura inglêsa, numa época em que, enfarado dos livros francêses, descobrira que o mundo das emoções artísticas não se confinava a Paris" (1955: 539-40) - e de quem traduziu alguns livros, como Kim e O livro da jângal:

\begin{abstract}
"Há bem pouco tempo só quem conhecia alguma outra língua podia entre nós pôr-se em contato com a universalidade - e para isso veio a fúria de absorver francês na classe que chamamos alta, ou que se chama a si própria alta. Essa gente escapou de um mal: muramento em vida dentro de uma língua paupérrima em literatura e para a qual, de tudo quanto a humanidade produziu, desde Lucrécio até Henry Mencken, só foram vertidos uns trabucos lacrimogêneos de Escrich e aquela galopada sem-fim, para ganhar dinheiro, de Dumas. Escapou de um muramento para cair noutro: murou-se no francês. O fascínio da França foi tão forte nessas almas simples que não conseguiram ir além. Pararam em Paris e, a fim de justificar a parada, encamparam a sério, botocudamente, a altíssima ideia que o francês faz de si próprio, do seu esprit, da sua comida, das suas francesinhas de bem fazer a quem lhas paga, da sua civilização faisandée, da sua grivoiserie eterna etc. etc. E tivemos por cá essa geração, ou essas compridas gerações de basbaques mais realistas do que o rei - mais franceses que o francês, negadores do resto do mundo por puro amor à França"6 (2010b: 277-8).
\end{abstract}

O "muramento" é criticado como uma fé cega, sem consistência. E os francófilos têm-se em conta mais alta do que sua arrogância, no entender do crítico, possibilita. Critica-se a comercialidade das obras francesas ("galopada sem-fim, para ganhar dinheiro, de Dumas"), a autocondescendência em adotar modelos estrangeiros (“encamparam a sério, botocudamente, a altíssima ideia que o francês faz de si próprio") e a pura elevação da França a um modelo inalcançável sem qualquer base forte a justificar essa visão ("negadores do resto do mundo por puro amor à França").

Em seu livro infantil Geografia de Dona Benta (1935), Lobato acrescentaria:

“- Fale da França, vovó (...).

- Pois a França é um país privilegiado. Possui todos os climas, um sistema de rios de primeira ordem, terras excelentes para grande variedade de culturas. Vem daí o caráter caseiro do seu povo. O francês não sai de casa, isto é, não sai da França. Ignora o resto do mundo. Não quer saber. Não viaja. Não estuda Geografia. Para quê, se está bem em casa?

\footnotetext{
${ }^{5}$ Mais adiante veremos novos exemplos dessa crítica, sobretudo na exposição da crítica ao "refinamento" literário, encontrada por exemplo em $O$ presidente negro.

${ }^{6}$ A Editora Globo, que organizou esse volume de compilação de textos "esparsos" de Lobato, não informa a data do artigo. Originalmente publicado em Mundo da lua, volume dedicado a textos da juventude do autor, lançado em 1923.
} 
Ficou profundamente egoísta. O mundo lá fora pode estar pegando fogo: o francês não se mexe. Limita-se a 'fazer espírito'. Somítico até ali. Agarradíssimo. A avareza dos campônios da França é proverbial. Trabalham como mouros, sempre rotineiramente, como os pais e avós fizeram, e só gastam o que é em absoluto indispensável" (2013: 219).

O paralelo evidencia-se não apenas pela presença certeira do mesmo vocábulo a definir o lado reprovável dos franceses ("espírito") como pela natureza dúplice da apreciação dos valores do povo da França: trabalhador, porém avaro; esforçado, porém avarento; aperfeiçoador da terra, e daí acomodado e desconhecedor de outras culturas. É também um "muramento", portanto. Os franceses muralham-se em sua própria terra, ficando assim um povo egoísta, ignorante do resto do mundo.

A influência da França nos anos de formação do jovem Lobato, contudo, delineiase de maneira transparente. Ele e seus amigos mais próximos identificavam-se com as personagens de um célebre romance francês do século XIX - "Porque todos nós andávamos cheios do Tartarin de Tarascon de Daudet e cada um personalizava uma das personagens do romance. Ricardo era o Tartarin. Rangel, o Bezuquet. Cândido Negreiros, o Bompard. Artur Ramos, o espingardeiro Costacalde. Eu, Pascalon, o Engraçado" (2010a: 35) -; em suas cartas usa à profusão termos franceses ${ }^{7}$; e sua lista de leituras é eminentemente uma lista de livros franceses, conforme levantamento e observações de Sueli Tomazini Barros Cassal ${ }^{8}$ :

"Lobato lia em francês e em italiano. Comprava seus livros na Casa Garreaux, na Livraria Alves e na Livraria Gazeau, geralmente sob encomenda. Até 1906, lê basicamente em francês. A partir de 1907, para preencher a modorra da vida de funcionário público em Areias, começa a ler em inglês e assina o Weekly Times de Londres (...), do qual traduz alguns artigos para a imprensa. Até os vinte e cinco anos, confessa que lera apenas meia dúzia de livros em português. Quando, por volta de 1916, volta-se para o estudo da realidade nacional, constata que sua biblioteca é muito pobre em obras em português. 'Quasi tudo em francês. Uma vergonha', comenta com Rangel” (2002: 119).

Por vezes, e ao longo de toda a sua vida e carreira, Lobato continuaria a usar galicismos, denúncia evidente de sua formação 9 . Em 1943, por exemplo, descreve o

\footnotetext{
${ }^{7}$ Exemplos ilustrativos da última edição da correspondência entre Lobato e Godofredo Rangel intitulada $A$ barca de Gleyre (2010), localizados nas cartas do ano de 1906: malsain (p. 118), tout passe (119), affaires (120), troupe (124), d'après nature (125). Na carta do dia 10 de setembro de 1906, Lobato chega inclusive a escrever sobre Flaubert em francês, bem como fala de suas novas leituras, entre as quais autores anglógrafos, com uma ressalva sintomática: Charles Dickens ele lê em francês.

${ }^{8}$ A pesquisadora compilou a lista exaustiva de autores e obras citados por Lobato em sua correspondência com Godofredo Rangel em A barca de Gleyre. O levantamento aponta cômoda vitória aos franceses, quantitativamente em número bem superior aos demais citados nas cartas: russos, ingleses, portugueses etc. ${ }^{9}$ Curiosamente, o escritor também pareceu seguir a vertente neologista quando voltou-se para Inglaterra e Estados Unidos: em texto de 1941, contraposto justamente ao valor do trabalho, um dos ícones que Lobato associava ao espírito americano e desenvolvimentista (ligado a "eficiência"), aparece o vocábulo "estarvar" (2009c: 83) advindo do inglês to starve: "passar fome".
} 
Visconde de Sabugosa como "um raté. Tentou várias evoluções e sempre 'regrediu' ao que substancialmente é: um sábio" (2010a: 552).

Num Brasil ainda de poucos livros, bibliófilos como o jovem Monteiro Lobato valiam-se de tudo que lhes caísse nas mãos, e os depoimentos dos leitores da época e a pesquisa das publicações que havia e circulavam $^{10}$ dão conta, ao menos em parte, de explicar a predominância francesa no espírito intelectual brasileiro - ao deixar exposta a exiguidade de material mais variado, fundamentalmente.

Anos depois Lobato voltar-se-ia para os textos infantis; em carta a Godofredo Rangel, alega que havia pouquíssimos livros à disposição das crianças brasileiras:

\begin{abstract}
"Não ficarei muito tempo nesta terra [Rio de Janeiro]. O calor!... já te disse que não tenho o trópico no sangue. Detesto os verdes eternos, o calor quase eterno, a tal primavera eterna que não passa da mais eterna e desesperante monotonia. Verde, verde, o ano inteiro! Tudo verde, como o Menino verde, um álbum colorido com que me diverti em criança, companheiro do João Felpudo: lembra-te disso? Pobres das crianças daquele tempo! Nada tinham para ler. Ando com ideias de entrar por esse caminho: livros para crianças. De escrever para marmanjos já me enjoei. Bichos sem graça. Mas para as crianças, um livro é todo um mundo. Lembro-me de como vivi dentro do Robinson Crusoe do Laemmert. Ainda acabo fazendo livros onde as nossas crianças possam morar. Não ler e jogar fora; sim morar, como morei no Robinson e n'Os filhos do Capitão Grant" (2010a: 513).
\end{abstract}

O pensamento aqui é equivalente: para os leitores em geral, oferecia-se muita Europa (Robinson Crusoe editado pelos irmãos alemães Laemmert), muita França (Os filhos do Capitão Grant, de Jules Verne) e pouco do restante do mundo ("Pobres das crianças daquele tempo! Nada tinham para ler"). Lobato começa a conscientizar-se e inquietar-se; há poucas traduções para outros idiomas, obras importantes que permanecem sem pisar solo brasileiro, correntes de pensamento novas que, por tradição, costume e comodismo, continuam inéditas para as gentes do Brasil.

Ao longo de sua trajetória, o inquieto Lobato tentou incessantemente dar sua contribuição para resolver a situação. Ele próprio trará para o país obras importantes, sobretudo em inglês, traduzirá dezenas de livros, mudará a feição de boa parte do que se

\footnotetext{
${ }^{10}$ Aludindo aos hábitos de leitura do cidadão médio que habitava a capital do país, Jeffrey D. Needell comenta que "o resultado [de tanta influência e importação de obras e hábitos franceses] foi um gosto carioca fin-de-siècle, formado e alimentado por obras francesas de uma forma cumulativa e discriminatória. A primeira geração romântica inspirou-se em Chateaubriand, Musset, Lamartine, Balzac, Sue e Hugo; a segunda incluiu Cherbuliez, Feydeau, Feuillet, Dumas filho, Sandeau e Scribe. Os leitores da década de 1880 fixaram-se em Hugo, Balzac e Flaubert, e apreciavam Zola, os Goncourt, Taine, Renan e Maupassant. Em 1900, fossem antigos membros da geração de setenta, boêmios da década de 1880 ou novos homens, os leitores continuavam apreciando Hugo, Balzac, Flaubert, Zola, Renan e Taine... e acrescentaram a eles os nomes então em voga de Anatole France, Paul Bourget, Pierre Loti, J.-K. Huysmans e Marcel Prévost” (1993: 231).
} 
discutia e se tinha por certo. Não é pouco: hoje contextualizamos a influência francesa nas letras e pensares brasileiros, porque os valores anglófilos parecem, curiosamente, estabelecidos com mais firmeza e evidência. Lobato foi um dos vetores de força que modificaram essa aparência do pensamento social-político-cultural do Brasil.

Um parênteses: não se trata de valorar negativamente a influência francesa ou de fazer a apologia irrestrita dos valores americanos e ingleses; a questão que se desnuda é a maior abrangência de visões, em meio aos planos de maior democratização da leitura e do conhecimento em meados do século $\mathrm{XX}$, quando Lobato e outros pensadores entenderam por bem alargar o campo de consumo e redefinir a logística da cultura de livros no Brasil: agora as novidades do mundo chegavam (ou chegavam mais rápido) e o país podia conhecer aquilo de que só ouvia falar - seja um fenômeno midiático como as Pollyannas de Eleanor H. Porter, seja os livros sobre empreendedorismo escritos por Henry Ford. Não é nosso objetivo deter-se nesse tópico, mas fique registrado que a verdadeira revolução na distribuição e recepção dos livros mudou definitivamente os rumos da cultura brasileira a partir de então.

Lobato pôde desenvolver seus projetos em uma miríade de empreendimentos: como tradutor, já o dissemos, trouxe obras inglesas e americanas que faltavam nas livrarias brasileiras.

Como editor, revolucionou a relação público-livro por meio de diversas abordagens: maiores tiragens dos livros, facilidades para adquiri-los, vendas em consignação para outros estabelecimentos além de livrarias (farmácias, armazéns, bancas de jornal), publicidade intensificada - Fernando Jorge escreve que "o autor de Cidades mortas causou escândalo quando resolveu anunciar as suas edições pelos jornais, porque como salientou Nelson Palma Travassos, ninguém acreditava que o livro também fosse 'mercadoria anunciável' (2008: 113).

Como autor, expôs em seus escritos suas ideias de progresso, civilização e avanço, entre as quais a gradativa mecanização dos primitivos trabalhos braçais, a desburocratização das esferas políticas e públicas, o uso massivo de ferro para o maquinário das empresas e do petróleo para movê-lo.

Assim, com as influências-base da França internalizadas, Lobato detém-se em analisar as benesses de outro sistema, qual seja, o dos países de língua inglesa. Aproximando-se peu à peu da língua inglesa, com a qual em verdade se bateria até o fim da vida - a neta Joyce disse em depoimento a Márcia Camargos: "meu avô falava um inglês horrível, com fortíssimo sotaque brasileiro. (...) Ele podia usar a gramática de modo 
correto, mas não fazia a mínima questão de melhorar a pronúncia. Fora isso, dominava um vocabulário magnífico, pois inclusive traduzia" (2007: 83); enxergamos também um pouco de ressentimento pela experiência frustrada que teve como "escritor internacional"11 -, deixa-se paulatinamente conquistar pela euforia propagada pelos exemplos dos países mais desenvolvidos economicamente, que dominam os meios de comunicação e a cena política.

Sua principal atração vira-se para o país que é o maior exemplo da autopropaganda no século XX: os Estados Unidos. Fascinado pelas notícias acerca de seus avanços científicos, seu sistema político particular e funcional e os valores (até morais) dos empreendedores e homens de visão americanos, Lobato vira uma espécie de "cabo eleitoral" da América no Brasil.

O American way of life captura-o e encanta-o pela eficiência, pela grandiosidade, por ser representar o paroxismo de um povo: o máximo, o melhor que se pode oferecer. Extrair as riquezas do solo do país, refiná-las e desenvolvê-las, alardeá-las, gestar um sistema cultural massivo que torne as pessoas conscientes e orgulhosas de fazer parte dessa nação, ter essas vantagens e benefícios, torná-las inquestionáveis a todos.

O americano, como Lobato o enxerga, é um povo que sabe de sua grandeza e se vale dela. $\mathrm{O}$ escritor começa a pensar que poderíamos transpor os métodos de sucesso para nossa terra e prosperar tanto como o país ianque. Em sua última década de vida, persistente em seus ideais, chegaria a sumarizar os Estados Unidos como "o país que todos nós sabemos o que pesa e o que vale" (2009c: 168).

É um ponto deveras discutível, reconheçamos; em parte correto e em parte completamente anatópico (fora de seu lugar), a ideia de Lobato tem seus acertos e falhas, que discutiremos oportunamente.

\subsection{HENRY FORD, O MESSIAS DE UMA NOVA ERA}

O guia para esse novo mundo tecnológico e social, em que a mecanização, a adequada exploração em larga escala das riquezas naturais e a busca da eficiência firmamse como os componentes de sua constituição, é, para Lobato, Henry Ford.

Exemplos abundam em sua obra, confundindo autor e expressão. Inegável constatar, não obstante, que Lobato não permanecia incólume ao fenômeno Ford.

\footnotetext{
${ }^{11}$ Veremos adiante como seus planos de "estourar" com o romance O presidente negro foram frustrados.
} 
Admirava sua audácia, o empreendedorismo que o enriqueceu, o exemplo de "possibilidades" que Ford legou à América e ao mundo: as linhas de produção, o trabalho ininterrupto, a não especialização dos trabalhadores (todo trabalho é relevante e deve ser realizado). A relação de deferência do autor brasileiro para com o empreendedor americano era manifesta. É ela que o faz lançar no Brasil, com sua própria tradução, dois livros de Ford (Minha vida e obra e Hoje e amanhã) em 1927, bem como How Henry Ford is regarded in Brazil, uma série de artigos originalmente publicados em 'O Jornal' e compilada, em inglês, no Brasil um ano antes ${ }^{12}$.

Cabe assinalar que no primeiro quarto do século XX a industrialização brasileira era incipiente, começando a se fazer notar, e não sem suas contradições. Caio Prado Júnior sentencia que "o ajustamento do Brasil à nova ordem imperialista se processou sem modificação substancial do caráter fundamental da economia do país, isto é, a produção precípua de gêneros destinados ao comércio exterior" (2002: 287).

Com um Brasil ainda em boa medida ruralizado, sem parques industriais e empresas de monta, sem relevância na economia internacional além do papel de exportador de commodities, arriscado diagnosticar hoje, no primeiro quarto do século seguinte, os impactos e mudanças que esse ajustamento, na expressão de Prado Júnior, representou.

Com relação especificamente a Ford e sua influência, o historiador repara que, já a partir da Primeira Guerra Mundial (1914-18), empresas como a General Motors e a Ford Motor Company "instalaram em São Paulo oficinas para montagem de veículos motores com peças importadas de suas fábricas norte-americanas; aos poucos, algumas destas peças ou partes dos veículos foram sendo fabricadas nessas oficinas" (2002: 267).

Isso leva a uma importante constatação, que talvez pareça evidente hoje e, contudo, traz em si considerações não vulgares: o fordismo era "importado". Quando Lobato se alinha a ele, quer "trazer ao Brasil" valores que não verificava aqui, ou que não existiam aqui ou eram praticados do jeito que entendia adequado. Uma revolução de fora do país para dentro dele. Seguindo o exemplo de "quem deu certo"13.

Ainda que fundamentada em consultas a jornais, livros e, num ponto de sua vida, em observações empíricas (em sua estada americana o escritor visitou as indústrias Ford), a euforia que Lobato sentia por Ford tem algo de infantil, no que vemos curiosa

\footnotetext{
12 Trata-se da mesma época em que Lobato publicou os primeiros colóquios de Mister Slang, assunto de nosso terceiro capítulo. Ford será citado explicitamente pela personagem lobatiana.

${ }^{13}$ Para entender em detalhes esse conceito, ver adiante nosso item 3.1.2.
} 
aproximação com seu projeto pedagógico para as crianças (ver nosso capítulo 4): Henry Ford deixa de ter contradições, suas controversas medidas são aceitas quase sem hesitação, o industrial vira uma criatura mítica, distanciada. Sob certo ângulo de visão, um ídolo religioso.

É de Lobato a expressão "messias" para se referir a ele, "messias da Ideia Nova", em O presidente negro (1967: 202); procedimento de resto comum em Lobato, que "legendariza" as figuras que admira ${ }^{14}$.

Lobato não se isola na opinião, contudo. O biógrafo Richard Snow aponta "sinais do messianismo" de Ford, comentando acerca de um setor da Ford Motor Company relacionado aos direitos dos trabalhadores:

\begin{abstract}
"Hoje, o Departamento de Sociologia pode parecer a essência do paternalismo sufocante, e muitos achavam isso mesmo naquela época. Sem dúvida, nenhuma outra grande empresa industrial tinha nada parecido. Mas com os seus serviços médicos e jurídicos e a escola de língua inglesa para atender aos milhares de funcionários imigrantes da empresa, o departamento parece ter ajudado mais do que prejudicado. Em 1914, o funcionário mediano da Ford acumulava US\$207,10 em economias. Para aqueles que permaneceram na empresa durante os cinco anos seguintes, a média subiu para US\$2.171,14.

A reformista Ida Tarbell foi a Highland Park com a intenção de expor o opressor sistema da Ford. Em vez disso, ela escreveu: 'Podem chamar do que quiserem - filantropia, paternalismo, autocracia -, mas os resultados obtidos valem todas as objeções que se lhes oponham, e os eventuais erros contidos no plano produzirão suas próprias medidas corretivas"” (2014: 279-80).
\end{abstract}

O excerto deixa entrever a complexidade das discussões que Ford motivou quando fundou e geriu suas empresas, seguindo um modelo até então inaudito no mundo, ao menos em tais proporções. Diante da perplexidade e incompreensão de boa parte do público, Ford desenvolveu uma publicidade que comportava inclusive visitas a seus empreendimentos. Assim como Ida Tarbell, Lobato também visitou as indústrias Ford, bem como a General Motors, em 1928, falhando, no entanto, para grande decepção sua, em conhecer o empreendedor pessoalmente. Marca Edgard Cavalheiro: "O que viu [em Detroit], assegura, daria um livro maior que a Enciclopédia Britânica. Almoça em companhia de Edsel Ford, na mesa redonda do estado-maior da grande Emprêsa. Não tem a alegria de ver o velho Ford, que se encontra na Escócia" (1955: 366).

A questão dos "resultados", também cara a Lobato, seria retomada em diversos momentos de sua obra, mormente aqueles em que fala abertamente sobre Ford e seus métodos. Discuta-se o populismo de suas medidas, discuta-se a filantropia de seus atos enquanto empresário, como Ida Tarbell inicialmente desejava; porém observe-se com

\footnotetext{
${ }^{14}$ Discutiremos os casos de D. Pedro II e de Lincoln, em nossos capítulos 3 e 4, respectivamente.
} 
critério as consequências de seus planos, o que disso adveio à economia e aos trabalhadores, ao progresso do país e ao desenvolvimento científico-tecnológico.

Em muitos livros lobatianos encontramos a defesa da "maquinização", ante críticas numerosas contra desemprego e mecanização das forças de trabalho - Lobato segue Ford ao considerar que os transtornos são temporários, da industrialização virão bens cada vez maiores às pessoas e aos países ${ }^{15}$.

Eric Hobsbawm aponta condicionantes e consequências do fordismo, atrelado a bens de consumo massificados e mecanização e tecnologia (tradução nossa):

\begin{abstract}
"Inicialmente esta impressionante explosão da economia parecia meramente uma versão gigante do que havia ocorrido antes; ou seja, uma globalização do estado pré-1945 dos EUA, pegando este país como o modelo de uma sociedade capitalista industrial. E, em alguma medida, assim o foi. A era do automóvel havia chegado faz tempo na América do Norte, mas depois da guerra apareceu para a Europa e depois mais modestamente para o mundo socialista e as classes médias da América Latina, enquanto combustível barato faziam do caminhão e do ônibus os maiores meios de transporte por quase toda a superfície do globo. (...)

O modelo da produção em massa de Henry Ford se espalhou além dos oceanos para novas indústrias automobilísticas, enquanto nos EUA o princípio fordista se estendeu a novos tipos de produção, de construção de casas a junk food (...). Bens e serviços anteriormente restritos a minorias agora eram produzidos para um mercado de massa (...). Em suma, agora era possível para o cidadão comum desses lugares viver como apenas o muito rico havia vidido no tempo de seus pais - exceto, claro, que a mecanização agora havia substituído os empregados pessoais.

De qualquer modo, o que nos choca mais sobre esse período é a amplitude com a qual a onda econômica parecia impulsionada pela revolução tecnológica" (1996: 263-4).
\end{abstract}

Atrelados às novas condições de distribuição de bens e serviços e execução do trabalho, chegam aos indivíduos novos poderes de consumo. Uma realidade que modifica significativamente as relações envolvendo trabalhadores, força laborativa, capital e congêneres. A participação de Henry Ford na alteração dessas dinâmicas é, mais que relevante, crucial. Com todas as críticas e questões que o modelo acarretaria, o fordismo proporcionou materialmente às massas "bens e serviços anteriormente restristos a minorias".

Flagrante observar que Ford assemelha-se a Lobato, ou vice-versa, também no sentido de dar vasta publicidade a seus feitos: comunicados, filmes institucionais e livros enchiam os olhos do mundo com propagandas e explicações de Ford e suas realizações industriais. Ford tornou-se assim não apenas um dos homens mais ricos, mas igualmente

\footnotetext{
${ }^{15}$ Vide em nosso anexo 1, comportando os livros lobatianos em que nos detivemos (a trilogia americana e um grupo específico de paradidáticos infantis), a crítica aos detratores ou inimigos da máquina.
} 
uma das mais conhecidas figuras do mundo, para o bem e para o mal: célebre ainda hoje a caricatura que o cineasta inglês Charles Chaplin fez de Ford como um inescrupuloso explorador da força laboral de seus empregados na ácida crônica cinematográfica Tempos modernos, de $1936^{16}$.

O aspecto publicitário ia ao encontro do espírito de Lobato, que passou ao menos a segunda metade de sua vida tentando tornar públicas suas campanhas, seus projetos editoriais, sua filosofia de homem público num Brasil ainda pouco interligado, com deficiências nos sistemas de comunicação e transporte - justamente as áreas em que o empreendedor americano havia mais arregimentado destaque.

Então não é à toa que Ford aparece muitas vezes citado, e sempre com admiração, nas obras do escritor ${ }^{17}$. Como um exemplo a ser "assimilado", Lobato retira de Ford a contemporaneidade e o transforma num exemplo perene (de Hoje e amanhã, portanto). É o farol que deve orientar os passos dos empreendedores que queiram fazer progredir sua nação.

Uma citação pontual a Ford em Mister Slang e o Brasil deixa entrever o que o escritor brasileiro vê de positivo no método do empresário americano:

\footnotetext{
“- Há dias li no Today and tomorrow, do grande Henry Ford, um livro que está fazendo furor no mundo mas que vocês inocentemente ignoram, uma opinião sobre o Brasil. Diz ele: "For while Brasil takes up one fifteenth of earth's surface and has extraordinary rich natural resources, it has not had transport facilities for development. A country develops only according to the ease of transport, and most of Brazil has only six months of transport by motor because, during the other six months, the roads are too heavy for any car to go through $h^{18}$ ". Vê? Ford tem a mentalidade dos povos estradeiros e, sem nunca ter estado aqui, compreendeu o que pouquíssimos brasileiros compreendem.

— Não há dúvida. As afirmações de Henry Ford são categóricas. "Um país só se desenvolve por meio da facilitação do transporte". É isso mesmo. Mas o assombroso fenômeno norte-americano explicar-se-á apenas pelo transporte?

- Passei o mês de outubro na América do Norte - respondeu Mister Slang - e posso dizer que não saí do meu automóvel. Em quatro semanas percorri 24 mil quilômetros, ou seja, uma média de 800 por dia... Para percorrer esta mesma distância no Brasil, São Paulo fora, o brasileiro vê-se forçado ao dispêndio de 666 dias!” (2008a: 104).
}

\footnotetext{
${ }^{16}$ No filme, a personagem do vagabundo (interpretado por Chaplin) aliena-se mentalmente ao ser posta para trabalhar, sob condições degradantes, em uma empresa que usa a linha de produção modelo Ford, com uma impiedosa e repetitiva separação de tarefas. $\mathrm{O}$ chefe da empresa, que só busca mais pretextos para enriquecer - chegando a testar no vagabundo uma cruel máquina automática de alimentação para o trabalhador (para que o empregado não pare de trabalhar nem quando come) -, possui uma notável semelhança física com Henry Ford, evidentemente não coincidental.

17 Também no Anexo 1: um levantamento parcial de citações a Ford, indústrias Ford e produtos Ford.

18 Tradução nossa: "Enquanto o Brasil toma um quinze avos da superfície da Terra e tem fontes extraordinárias de recursos naturais, não tem logística de transportes em desenvolvimento. Um país se desenvolve apenas de acordo com a facilidade de transporte, e a maior parte do Brasil tem apenas seis meses de transporte a motor porque, nos outros seis meses, as estradas são pesadas para a travessia de qualquer carro". Os grifos não são nossos.
} 
Henry Ford não é visto como um fenômeno tipicamente americano, mas antes um exemplo que serve a todos e pode especialmente ser útil aos brasileiros, caso se dispusessem a estudar suas lições e "compreendessem-nas". Para Lobato e suas personagens, a filosofia do empreendedor ianque tem o que se necessita para virar o norte de qualquer país, ou ao menos dos países estradeiros, que serão desenvolvidos por meio da facilitação do transporte.

O texto de Ford, importa reiterar, chegou ao Brasil por empenho do próprio Lobato, que traduziu os principais livros do empresário e lançou-os aqui em seus selos editoriais. Hoje e amanhã, de onde saiu o excerto comentado pelas personagens, editouse originalmente em 1927, pela Companhia Editora Nacional, editora de que Lobato era sócio-fundador ${ }^{19}$.

Faz-se, desse modo, uma ponte intertextual cujas referências o escritor paulista deseja que se façam conhecidas de seu leitor, orientando-o para um volume recomendado para a complementação do assunto, sob responsabilidade do autor do texto que ora leem. Como se acenasse a seu público, dizendo: "é preciso que se entenda que Henry Ford falou isso, e para tanto nada melhor do que ler o que Henry Ford efetivamente disse".

O texto em inglês possui a autoridade da citação direta, de cujas intenções não se pode duvidar. O exemplo torna-se quase arquetípico para Lobato, pensando em seu público, pois Henry Ford, conhecido mundialmente, associa-se à ideia de alguém que fez e prosperou, não um mero comentador exógeno aos fatos e eventos que reporta.

Dizem os pesquisadores de Monteiro Lobato: Furacão na Botocúndia:

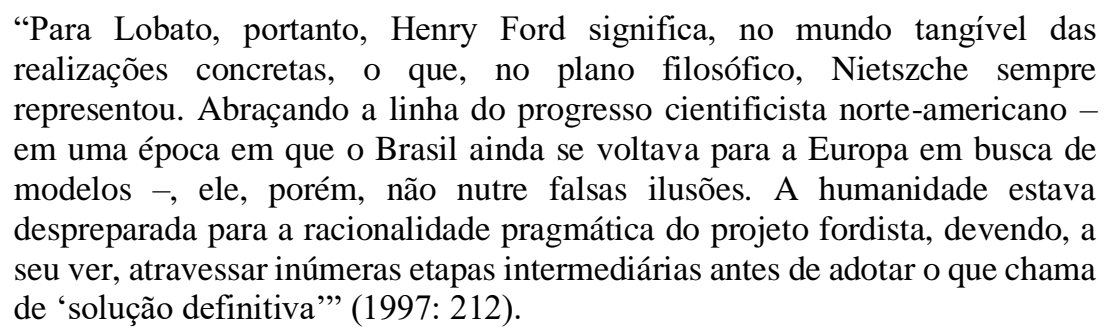

A "americanofilia" de Lobato encontra, portanto, em Henry Ford o ápice e o resumo de suas intenções. A escolha de um exemplo bem-sucedido; a diluição de suas controvérsias (como a mecanização da força de trabalho) em prol de uma idealização do resultado eficiente obtido (avanço tecnológico, difusão do consumo); o

\footnotetext{
19 Edgard Cavalheiro comenta a gênese dessa empresa: "E assim, dos escombros da Gráfico-Editôra Monteiro Lobato surge outra pequena emprêsa - a Cia. Editôra Nacional" (1955: 261).
} 
empreendedorismo pessoal; a exploração dos recursos naturais para o progresso econômico (exploração de ferro, extração de petróleo); uma figura forte, enfim, que possa dirimir, com suas qualidades de líder, os empecilhos ao desenvolvimento de uma nação, mostrando que é possível, para além da burocracia governamental e da inércia das pessoas, catalisar a prosperidade de uma terra (Brasil) que, em comparação aos Estados Unidos, se nada perde em extensão e quantidade de recursos, supera-os em preguiça, má vontade, incompetência.

Caio Prado Junior entende que "a origem de seu [de Lobato] pensamento encontra-se na consideração deste povo maltratado e sofredor que é o brasileiro (...). Mais tarde, o espetaculo da grandeza norte-americana fez-lhe ver o que podia e devia ser um Brasil libertado de suas duras contingencias materiais" (1951b: X).

Tem-se delineado um quadro em que o Brasil será visto como um modelo a recuperar, com o valioso auxílio do exemplo vindo dos Estados Unidos. A trilogia americana dará sua contribuição para, assim como Ford, liderar mudanças sutis que em tudo farão diferença e ensejarão a grandeza do Brasil, na visão entusiástica de Lobato.

Discutiremos nos próximos capítulos os acertos e erros dessa perspectiva, enquanto analisaremos questões textuais relevantes a nosso escopo. 


\section{O PRESIDENTE NEGRO OU LOBATO SONHA A AMÉRICA}

\subsection{CONTEXTOS E ANTECEDENTES}

Vimos no capítulo anterior considerações sobre o apreço e afinidade que Monteiro Lobato sentia pelos Estados Unidos, sua estrutura e sua organização econômico-social. Particularizaremos a discussão, passando a investigar como ele veicula essas ideias e entusiasmos "americanos", em dois grandes momentos: a trilogia americana, constante em sua literatura adulta ou geral, e alguns volumes de sua literatura infantil ${ }^{20}$. Analisando esses dois blocos, dividiremos o assunto em subtópicos relacionados aos livros, temas e personagens.

A circunscrição desta parte do estudo, dedicada à exploração de seus livros para adultos, inicia-se no ano de 1926. No meio da década de 1920, Lobato é já um vulto de destaque: um dos principais jornalistas críticos de arte do Brasil (produção compilada em Ideias de Jeca Tatu), publicou um inquérito sobre o saci-pererê (relacionado a uma enquete popular que fez para um suplemento de O Estado de S. Paulo), algumas histórias infantis e aclamados livros de contos: Urupês, o primeiro e principal deles, veio à luz em 1918 e tornou-se um marco editorial. João Luís Ceccantini o chama de "o primeiro bestseller brasileiro" (2014: 43).

O nome de Lobato estava já, portanto, consideravelmente estabelecido. Isso permitiu relativa viabilidade ao intelectual paulista para estender seus empreendimentos para diversas frontes: além de escritor e autor, Lobato vem se firmando por essa época como relevante editor, tradutor e empresário. Essas atividades davam considerável suporte logístico (condições financeiras para projetos pessoais) e justificativa "social" para Lobato objetivar iniciativas cada vez mais ambiciosas.

O escritor, então, adensa sua carreira de publicista, defensor de causas públicas, agitador político. Suas causas particulares e regionais, como as relativas aos aspectos sanitários da roça paulista (notoriamente em Uma velha praga, célebre denúncia jornalística que depois adentra Urupês), ganham camadas de complexidade e viram causas maiores, gerais e propriamente nacionais. Monteiro Lobato agora fala ao Brasil.

O Brasil de meados dos anos 1920 é um Brasil conturbado política e culturalmente. Em 1922, a Semana de Arte Moderna mudou boa parte dos rumos do jogo

\footnotetext{
${ }^{20}$ A razão para a escolha de determinadas obras infantis será oportunamente esclarecida.
} 
cultural-artístico no Brasil, ainda que sejam discutíveis suas intenções, métodos e mesmo seu alcance. Introduzindo no Brasil um sectarismo ainda não plenamente dimensionado, os efeitos se fariam notar por muitas décadas. São Paulo, graças ao café o estado mais rico do Brasil, e Monteiro Lobato, possivelmente o crítico mais célebre do jornalismo brasileiro da época, viram surgir atabalhoadamente novos autores, ideias e ideais, que viriam a se difundir em muitos campos e estados nos anos seguintes, sob múltiplas facetas e estéticas: regionalismo, futurismo, entre outras ${ }^{21}$.

Discute-se a relação de Lobato (tido habitualmente como um "pré-modernista") com os principais artistas modernistas, capitaneados por Mário e Oswald de Andrade ${ }^{22}$. É célebre o caso do artigo Paranoia ou mistificação?, crítico à arte de Anita Malfatti ainda que seja complexa a relação de Lobato com os valores da modernidade estética. Uma indagação, que não é dever deste trabalho responder: desejariam os modernistas deliberadamente indispor opiniões contra Lobato? Em caso afirmativo, o que os movia a isso? O próprio Lobato arriscaria, raciocinando no fim de contas, uma hipótese:

\begin{abstract}
"No fundo, o que há contra mim é inveja em conseqüência de minha vitória comercial nas letras. Até o fim do ano, passo de 2 milhões em minhas tiragens. Estou (ou vou ficar até o fim do ano) com 66 edições aqui e 37 na Argentina (ou mundo de língua espanhola), tudo isso dando renda. Aqui é que esta o busílis. Elles, por mais que eu escondesse o leite, descobriram que o ano passado paguei 54 mil cruzeiros de impôsto sobre a renda - renda exclusiva de direitos autorais. Isso sem contar a minha renda na Argentina. Êles, são uns gênios - mas não vendem; têm que viver como carrapatos do Estado, presos a empreguinhos. O Lobato é uma bêsta, mas está vendendo bestialmente, cada vez mais. Daí o atual "pau no Lobato"” (1969: 178).
\end{abstract}

No aspecto político, o governo federal do país, sob a gestão Artur Bernardes (1922-6), via-se às voltas com enorme e generalizada impopularidade administrativa, herdada do governo de seu antecessor Epitácio Pessoa (1919-22). Os problemas com que Bernardes deparou foram de tamanha envergadura que o presidente achou adequado decretar estado de sítio em porção substanciosa de seu mandato de quatro anos.

Insatisfação em grau maior era manifestada, sobretudo, pela baixa oficialidade militar. As demandas dos revoltosos, chefiados pelo general reformado Isidoro Dias Lopes, incluíam o direito ao voto secreto, à justiça gratuita e o ensino público obrigatório. Monteiro Lobato parecia concordar com boa porção das reivindicações, indo de encontro ao poder oficial e questionando vários de seus fundamentos.

\footnotetext{
${ }^{21}$ O papel de Lobato nesse boom não é apenas passivo, pois, como editor, ajudou a lançar muitos novos autores e tendências literárias, estéticas, artísticas e culturais.

${ }^{22}$ Inclusa como anexo uma breve análise da correspondência entre Lobato e Mário, feita em uma das disciplinas da pós-graduação no IEB-USP, que ajuda a dimensionar a questão.
} 
Com relação ao voto secreto, por exemplo, Lobato chegou mesmo a escrever uma carta aberta ao presidente Bernardes. Nela, afirma que a experiência de eleições realmente democráticas, com a instituição do voto secreto, dera certo em outros países (nossos vizinhos Argentina e Uruguai, inclusive), que “cairam num admirável equilíbrio politico, cessando neles a fase das revoluções" (1967: 303).

Ou seja, Lobato associa o período de crise do governo Bernardes a essa perpetuação do atraso, verdadeiro descompasso da nação, que a administração do presidente não dirimia - e que a seu ver até mesmo facilitava a ação dos revoltosos, pois "governo revolucionario ou governo legal, para o povo é tudo um, já que nenhum é livremente escolhido por ele" (1967: 301). Com a instauração do voto secreto e livre, Lobato vaticina que "no dia em que tal acontecer, os governos passarão a exprimir fielmente a vontade nacional, e a opinião estará com eles, porque os escolheu com liberdade. A politica deixará de ser o que é, méro negocio de um grupo, e abrir-se-á a todas as capacidades" (1967: 302). Lobato defenderia o voto secreto e livre em outros momentos de sua carreira.

O governo Bernardes não via com bons olhos as exigências tenentistas, todavia. As tensões não acalmadas ocasionariam confrontos cujo momento mais extremado foi a Revolta Paulista de 1924, o maior conflito bélico da cidade de São Paulo. O presidente Artur Bernardes resolveu a situação de modo igualmente extremado: ordenou o bombardeamento da cidade. Lobato, em Mister Slang e o Brasil, disse, anos depois: “O nosso último presidente (...) também possuía esse espírito [o senso da irrealidade]. (...) E preparou o terreno bombardeando a cidade... A história meterá o bombardeio da cidade entre os sadismos que não têm perdão" (2008a: 47) ${ }^{23}$.

Sucedendo a Bernardes, Washington Luís (1926-30) consegue acalmar um pouco os ânimos: decreta o fim do estado de sítio que marcou o governo anterior (subsistindo apenas em parte, visando a deter a Coluna Prestes), libertou presos políticos e efetivamente extinguiu presídios usados para encarcerá-los - entre os quais o da Clevelândia, no Amapá, "uma antiga colônia militar convertida em prisão, em meio à floresta amazônica" (2015: 201). Lobato alude a ela em vários momentos; no livro anteriormente mencionado ironiza o ex-presidente em uma fala mordaz de sua personagem Mister Slang, que ora comentava o caso de um senador ímprobo: "Esse

\footnotetext{
${ }^{23}$ As palavras ecoam "publicamente" o mesmo que Lobato disse privadamente ao amigo Rangel em carta de 30 de julho de 1924: "Nem mais em São Paulo, a terra clássica da paz, existe paz hoje! Revolução em São Paulo! Bombardeio de São Paulo! Quem jamais admitiu semelhante absurdo?” (2010a: 493).
} 
homem merecia ser inimigo do doutor Bernardes e passar uns anos de vilegiatura na Clevelândia" ${ }^{24 ”}$ (2008a: 110). O escritor deixa claro que a seu ver as punições desmesuradas do mandatário precedente devem-se fundamentalmente a quem se manifesta contra o próprio “doutor Bernardes"...

Os ares afiguravam-se como de relativo otimismo, após as graves instabilidades verificadas na gestão do presidente anterior. O novo presidente relacionava-se melhor com setores indispostos pelo trato deficitário de Bernardes, e entre os grupos beneficiados por essa melhoria estava a intelectualidade. Um exemplo: Washington Luís publicou documentos importantes do Arquivo Nacional, uma fonte relevante de nossa história escrita, então em vias de deterioração. Sendo o candidato endossado pelo governo fracassado, Mister Slang afirma achar "a mais absurda das contradições a escolha do senhor Washington Luís, que é positivamente honesto, ter sido feita por um homem do qual não se pode dizer o mesmo" (2008a: 52).

Monteiro Lobato parecia satisfeito com a eleição. Em 1926, manda, a exemplo do que fizera no governo antecedente, uma carta aberta ao presidente, em que se coloca ao lado dos interesses da indústria nacional, compactuando com o famoso lema de Luís "governar é abrir estradas".

Essa visão desenvolvimentista, como dissemos no capítulo anterior, ia ao encontro das ideias que corriam mundo sob inspiração de Henry Ford, o empreendedor símbolo máximo do pensamento tecnológico-econômico dos Estados Unidos de então.

\subsection{UM LIVRO BRASILEIRO PARA OS ESTADOS UNIDOS}

Em 1926, nesse conturbado contexto, Lobato escreve seu primeiro e único romance para adultos: $O$ presidente negro. Talvez a mais antiga menção ao empreendimento, então já em avançado estado de elaboração, seja a carta ao amigo Rangel escrita em 8 de julho de 1926, em que diz:

\footnotetext{
"Sabe o que ando gestando? Uma ideia-mãe! Um romance americano, isto é, editável nos Estados Unidos. Já comecei e caminha depressa. Meio à Wells, com visão do futuro. O clou será o choque da raça negra com a branca, quando a primeira, cujo índice de proliferação é maior, alcançar a branca e batê-la nas urnas, elegendo um presidente preto! Acontecem coisas tremendas, mas vence por fim a inteligência do branco. Consegue por meio dos raios $\mathrm{N}$, inventados pelo professor Brown, esterilizar os negros sem que estes deem pela coisa.
}

\footnotetext{
${ }^{24}$ Moacir Assunção compila dados de um relatório de 1926: “dos 946 prisioneiros desterrados para a Clevelândia depois da derrota na Revolução de 1924, 444 haviam morrido de impaludismo, disenteria bacilar, tuberculose e outros males típicos de regiões tropicais" (2015: 201).
} 
Já tenho um bom tradutor, o Stuart, e em Nova York um agente que se entusiasmou com o plano e tem boa porcentagem no negócio. Imagine se me sai um best seller! Um milhão de exemplares..." (2010a: 514).

O plano de Lobato é preciso: escrever um livro que possa fazer carreira nos Estados Unidos ${ }^{25}$. Sua meta é essencialmente mercadológica: alcançar o milhão de exemplares vendidos para os americanos. É uma ideia concebida via diversos caminhos, desenvolvidos para assegurar a consecução do intento e seu feliz encaminhamento comercial.

Antes mesmo de terminar o livro, Lobato, tradutor experimentado do inglês - um levantamento do Instituto de Estudos da Linguagem (IEL) da Unicamp chega a apontar pelo menos cinquenta traduções feitas por $e^{26}$, a maior parte de obras originalmente publicadas na língua de Shakespeare ou versões em inglês de outros idiomas -, escolheu outra pessoa para traduzir seu livro.

Há poucas informações sobre o citado Stuart, como os reclames veiculados nos dias 5 e 8 de janeiro de 1927 em 'O Jornal'27 - anunciando no rol de traduções do romance lobatiano a "bella traducção de Aubrey Stuart". Não se dispõe, igualmente, de maiores dados acerca de sua tradução, que não pudemos aferir se completada, iniciada ou sequer existente. A decisão deixa entrever um provável desejo de maior profissionalização das etapas de feitura de um livro para o mercado estrangeiro: a obra não será traduzida pelo próprio autor, como num esquema caseiro, mas por um tradutor cuja única preocupação seria verter o livro para o outro idioma, visando exclusivamente a transformar o texto brasileiro em uma redação fluida e palatável ao público americano (ou anglófono).

A planificação das rendas advindas da comercialização do livro é também de se notar, no entusiasmo de Lobato na carta a Rangel. O escritor ainda está desenvolvendo o livro, mas já pensa na divisão dos lucros das etapas de feitura do objeto, em sua carreira internacional e até em um agente para intermediar a negociação!

O presidente negro, portanto, nasce como um ambicioso projeto de Lobato para o mercado americano, sobretudo; pouco o escritor paulista se interessa, nesse

\footnotetext{
${ }^{25}$ O autor não era inédito nos Estados Unidos. Em 1925 a editora Haldeman-Julius publicara Brazilian Short Stories, com tradução de três contos lobatianos para o inglês: The penitente wag ( $O$ engraçado arrependido), The plantation buyer (O comprador de fazendas) e Modern torture (Suplício moderno), conforme pesquisa de Rosemary de Paula Leite Carter (2012).

${ }^{26}$ BOTTMAN (2011).

${ }^{27}$ Dado fornecido por Luís Hellmeister de Camargo ao autor do trabalho em sua defesa de mestrado (2019). Camargo também nota que na página 201 de Monteiro Lobato, livro a livro: obra adulta há uma menção a Stuart como tradutor dos artigos publicados em 'O Jornal' e que comporiam o volume "How Henry Ford is regarded in Brazil".
} 
empreendimento, pelo público brasileiro - apesar de o romance haver saído primeiramente em terras brasileiras, em formato folhetinesco no jornal 'A Manhã'.

Para alcançar um público tão diferente do brasileiro, Lobato mira longe. Resolve fazer uma narrativa longa, um romance. E não apenas um romance ordinário, extensão de seus contos populares, mas um verdadeiro romance de gênero, qual seja, o gênero da ficção científica. Lobato era admirador de H. G. Wells e traduziria futuramente algumas de suas obras ${ }^{28}$. Em carta de 1905 a Rangel, Lobato escreveu:

“Ando com ideias dumas coisas à Wells, em que entrem imaginação, a fantasia
possível e vislumbres do futuro - não o futuro próximo de Júlio Verne,
futurinho de cinquenta anos, mas um futuro de mil anos. Vou semear agora
essas ideias e deixá-las se desenvolverem livremente por dez ou vinte anos -e
então limito-me a fazer a colheita, caso a plantação subsista até lá. Se a terra
dos meus canteiros mentais não for propícia a essas sementinhas, então é que
não estou destinado a ser o H. G. Wells de Taubaté, e paciência” (2010a: 100).

Curiosamente, além de tantas previsões que podem ser imputadas a Lobato em $O$ presidente negro, o escritor parece ter antevisto a própria elaboração de sua obra, aproximadamente vinte anos depois da carta a Rangel. O presidente negro, publicado em volume intitulado $O$ choque [das raças] quando de sua publicação em livro em 1926, traz em sua folha de rosto o seguinte subtítulo, preservado nas edições posteriores: Romance americano do anno de $2228^{29}$.

A abordagem não é sutil. Desde o princípio a obra é propagandeada como “americana", apesar de, essencialmente, passar-se no Brasi1 ${ }^{30}$. A ideia que Lobato gestava há anos materializa-se, assim, com todos os elementos almejados: um livro à Wells, "americano" desde sua concepção e sobre o futuro relativamente distante - mais precisamente, trezentos e dois anos adiante.

\footnotetext{
${ }^{28} \mathrm{O}$ IEL aponta versões de $A$ construção do mundo: $O$ trabalho, a riqueza e a felicidade do mundo e de $O$ destino da espécie humana publicadas por Lobato em 1943 e 1945, respectivamente (BOTTMAN, 2011). Contudo, o próprio Lobato aponta uma tradução sua, então em andamento, de $O$ homem invisível, um dos romances de sci-fi mais conhecidos de Wells, em carta de 16 jun. 1924 a Godofredo Rangel (2010a: 541). A pesquisadora e tradutora Denise Bottmann localizou a tradução no quinto volume (publicado em 1961) da Coleção Biblioteca do Leitor Moderno, apontando também como 1934 o ano de publicação pela Companhia Editora Nacional (BOTTMAN, 2018). Os pesquisadores de Monteiro Lobato: Furacão na Botocúndia apontam ainda "História do futuro (...), entre outros títulos, [que] ele traduziria nas décadas de trinta e quarenta" (1998: 217). Por fim, Edgard Cavalheiro aponta uma quinta tradução de Wells feita por Lobato: A ilha das almas selvagens, indicando apenas o total de páginas (204), não o ano da publicação (1955: 761) - Gisele Tyba Mairink Redondo Orgado e Ronaldo Lima, no verbete do Dicionário de tradutores literários do Brasil (2013), estabelecem o ano de 1935 para a publicação dessa tradução.

${ }^{29} \mathrm{Na}$ capa, os dizeres são levemente diferentes: logo abaixo do título $O$ choque, estão os dizeres Romance do choque das raças na America no anno de 2228. Na folha de rosto, Lobato preservou os dois títulos da obra, estabelecendo definitivamente na edição de suas Obras Completas, em 1946, o segundo, como é hoje conhecido. Na Argentina, onde foi publicado em 1935, saiu diretamente como El presidente negro.

${ }^{30}$ A rigor, a ação presente se passa no Brasil e a ação narrada, futurista, dá-se em terras americanas. Mais comentários adiante neste capítulo.
} 


\title{
2.3. LINHAS GERAIS DA TRAMA
}

Apresenta-se a história de Ayrton Lobo, também o narrador do livro, um funcionário mediano de uma firma burocrática de nome Sá, Pato \& Cia.

Ayrton, jovem devaneador, tem horror à mediocridade que o cerca, ou o que lhe parece como tal. Sonha em ter um automóvel potente para colocar-se acima das pessoas comuns. De posse de um Cadillac, sofre um acidente ${ }^{31}$ e é recolhido no lar da família Benson, composta pelo professor Benson e sua filha Jane. O professor e Miss Jane apresentam a casa a Ayrton, a quem confidenciam estranhos e inauditos experimentos científicos.

Benson desenvolveu um aparato que permite observar o futuro, como em uma tela de cinema, designado porviroscópio. Manipulando os comandos do aparelho, pode-se ver qualquer povo ou circunstância localizados até o ano 3527, a partir de quando os poderes do aparelho se enfraquecem sobremaneira e impedem sua correta utilização.

Em conversas amigáveis, ainda que Ayrton sinta-se perdido e mesmo inferiorizado em muitas ocasiões, as três personagens vão conversando sobre o futuro até que um evento sinistro ocorre: a morte do professor, que vinha sentindo constantes indisposições, relativas a uma doença terminal que o acometia. O professor, antes de morrer, acreditando que suas invenções poderiam causar males, caso disponibilizadas a agentes perigosos, declara à filha ter destruído tudo o que produziu:

\begin{abstract}
"Há já algum tempo que me sentia mal. Ocultava-o a ti para evitar-te um sofrimento inutil. Mas esta noite percebi que chegara o fim. Quando te deixei no gabinete com pretexto de concluir um trabalho, iludi-te, ou, melhor, vim fazer um trabalho muito diverso do que poderias supor. Vim destruir a minha descoberta. Queimei toda a papelada relativa e desmontei as peças mestras dos aparelhos. O que resta nenhuma significação possue e não poderá ser restaurado. Desfiz em meia hora o trabalho de toda uma vida. Da minha invenção restam apenas as impressões que te ficaram na memoria. E quando por tua vez morreres, tudo se extinguirá...” (1967: 189-90).
\end{abstract}

Destruído o porviroscópio e extinguida qualquer possibilidade de consertá-lo, resta a Miss Jane uma maneira de perpetuar os achados de seu pai e fixar o futuro de modo indelével "no presente": essa maneira é o livro ${ }^{32}$.

\footnotetext{
${ }^{31}$ Luís Hellmeister de Camargo enxerga no acidente uma conotação curiosa: “Ayrton Lobo, por sua vez, é um funcionário do comércio um tanto delirante. Dividiu o mundo em duas castas e acha superiores os rodantes. E acaba perdendo todas suas economias num acidente automobilístico. Uma crítica involuntária ao fordismo..." (depoimento ao autor em sua defesa de mestrado, 2019).

32 Essa perspectiva é também a idiossincrasia de Monteiro Lobato, e por isso mais além detalharemos o procedimento.
} 
O restante de $O$ presidente negro trata da "história dentro da história", que Miss Jane narra a Ayrton Lobo, de memória, constituída dos fatos que pôde observar no aparato ora desmontado que fora criado por seu pai. Somos informados do que afinal houve no ano de 2228 e qual o papel da personagem-título no imbróglio. A estrutura do romance se altera significativamente nesse ponto, o que discutiremos adiante.

Os Estados Unidos estão prestes a escolher seu $88^{\circ}$ presidente. Por conta de séculos continuados de teorias raciais e políticas sociais controversas, a sociedade americana se encontra rachada. Os partidos estão rigorosamente separados em três grandes blocos, que representam o seccionamento da nação: o dos homens brancos, o das mulheres brancas e o dos negros. O presidente atual, Kerlog, pertence ao primeiro partido. A líder do segundo é Evelyn Astor, seguidora de uma espécie de "profeta feminista", apocalíptica e intransigente, conhecida como Miss Elvin. O terceiro partido é capitaneado por James Roy Wilde, vulgarmente Jim Roy.

Miss Jane assume para si o encargo de deixar Ayrton Lobo (e, de forma correspondente, o leitor de Lobato) a par de toda a intrincada rede de mudanças sociais, políticas e raciais ocorridas desde 1926, data da ação da história e da publicação de $O$ presidente negro, até 2228, quando ocorre a fatal eleição do novo presidente dos Estados Unidos. Desconsiderando a força "unitária” do bloco negro, Miss Astor e Kerlog querem apenas o apoio de Jim Roy e seus sectários para que um deles, branco, possa eleger-se.

Jim Roy, em lances dramáticos prolongados pela narração contida e de suspense de Miss Jane, toma uma decisão inesperada e apresenta-se ele mesmo como candidato. Ayrton, imediatamente, externa surpresa. Miss Jane, contadora onisciente daquele caso, saboreia o efeito que sua narração provoca:

"Arregalei os olhos de surpresa. Nem por sombras eu havia imaginado aquela
hipótese e confessei-o a miss Jane.
- A surpresa não foi unicamente sua, senhor Ayrton. Alguns minutos
passados depois do gesto decisivo do formidavel Jim Roy, e cinquenta milhões
de eleitores negros recebiam a imprevista senha [para votar em Roy] como se
recebessem violenta pancada no cranio. A sensação de atordoamento foi
geral $^{33 "}$ (1967: 253).

Eleito, Jim Roy desespera os brancos americanos, que percebem que as teorias políticas e sociais que separaram homens e mulheres acabaram por possibilitar a ascensão da raça negra ao poder. As considerações eugênicas e raciais do livro são complexas e

\footnotetext{
${ }^{33}$ Esse efeito de surpresa, que será mimetizado pelo próprio Ayrton ao escrever o romance, e evidentemente por Lobato ao conceber o livro, será comentado neste capítulo, ao apreciarmos a estruturação metalinguística de $O$ presidente negro.
} 
controversas, mas não objetivamos determo-nos sobre elas. Falaremos apenas que a cruel solução concebida e praticada pelos brancos para resolver o caso do presidente negro Jim Roy encerra a narrativa de Miss Jane e conclui a narrativa de $O$ presidente negro, com um enlace feliz para Ayrton Lobo e Miss Jane ${ }^{34}$.

\subsection{INSTÂNCIAS NARRATIVAS}

O presidente negro apresenta múltiplas instâncias narrativas, que se alternam, sucedem ou misturam em vários momentos, por ação das personagens ou do próprio escritor. Apenas à guisa de rápida ilustração, um exemplo: Ayrton Lobo, quando embasbacado pelos méritos que vê em miss Jane, confunde a instância da realidade que o cerca com a de sua imaginação apaixonada, crendo ser possível que a jovem se interesse igualmente por ele.

Tais instâncias dividem-se em pelo menos três grandes categorias:

\subsubsection{IMAGINAÇÃO}

Ayrton Lobo, enquanto narrador, constrói castelos com sua fantasia. Quando decide adquirir um carro, dá-se a evolução perspectiva na seguinte gradação: cogitação (Ayrton quer um carro), intento (quer um carro pois acredita que é uma marca de ascensão social), execução (adquire um carro), consequência imediata (sente-se superior aos pedestres), consequência mediata (bate o carro). Todo o desenvolvimento do episódio, por mais material que se nos afigure, por possuir objeto e ação, é essencialmente mental ou psicológico.

Vejamos como Ayrton Lobo descreve, no primeiro capítulo do livro, seu ideal:

"Mas todos nós possuimos um ideal na vida. Meu amigo corretor sonha dirigir
a carteira cambial de um banco. Aquele pobre que ali passa, tocando o realejo
que herdou do pai e ao qual faltam tres notas, sonha com um realejo novo em
que não falte nota nenhuma. Eu sonhava... com um automovel. Meu Deus! As
noites que passei pensando nisso, vendo-me no volante, de olhar firme para a
frente, fazendo, a berros de klaxon, disparar do meu caminho os pobres e
assustadiços pedestres! Como tal sonho me enchia a imaginação!
Meu serviço na casa era todo de rua, recebimentos, pagamentos, comissões de
toda especie. De modo que posso dizer que morava na rua, e o mundo para
mim não passava de uma rua a dar uma porção de voltas em torno da terra.
Ora, na rua eu via a humanidade dividida em duas castas, pedestres e rodantes,

${ }^{34} \mathrm{O}$ final de ambas as personagens, com um beijo cinematográfico, emula a conclusão da "história dentro da históra": o presidente Kerlog e Miss Astor também ficam juntos e "reúnem" a raça branca... 
como os batizei aos homens comuns e aos que circulavam sobre quatro pneus. O pedestre, casta em que nasci e em que vivi até aos 26 anos, era um ser inquieto, de pouco rendimento, forçado a gastar a sola das botinas, a suar em bicas nos dias quentes, a molhar-se nos dias de chuva e a operar prodigios para não ser amarrotado pelo orgulhoso e impassivel rodante, o homem superior que não anda, mas desliza veloz. Quantas vezes não parei nas calçadas para gozar o espetaculo do formigamento dos meus irmãos pedestres, a abrirem alas inquietas á Cadillac arrogante que por eles se metia, a reluzir esmaltes e metais! O ronco de porco do klaxon parecia-me dizer - "Arreda canalha!"35

Sonhei, portanto, mudar de casta e por minha vez levar os pedestres a abriremme alas, sob pena de esmagamento. E o novo peculio (...) não visava outra coisa. Foi, pois, com o maior enlevo d'alma que entrei certa manhã numa agencia e comprei a maquina que me mudaria a situação social. Um Ford" (1967: 131-2).

Ayrton Lobo desnuda assim traços reveladores de seu caráter, que influenciam sua visão de mundo e, por conseguinte, seu estilo narrativo e o método de expor e ordenar os fatos constantes em sua narração. Desde o começo fica patente a distância que a personagem coloca entre ela e outros homens - ou entre ela e a própria coletividade, em certa medida.

Apesar de iniciar o relato de sua ambição irmanando ao seu outros desejos ("meu amigo corretor sonha dirigir a carteira cambial de um banco"; "aquele pobre [...] sonha com um realejo novo"), aos poucos os traços distintivos do delírio consumista de Ayrton revelam-se em maior amplitude. Logo no parágrafo seguinte ele simplesmente "divide em castas" a humanidade inteira! Com um binarismo simplório (ainda que, a seu ver, tremendamente lógico), Ayrton percebe-se de um lado (os pedestres) e quer passar a outro (rodantes).

Tal desejo é tão superlativo, em sua estruturação hiperbólica da aquisição dos bens capitalistas, que Ayrton acredita que adquirir o automóvel (não coincidentemente, um Ford) "mudaria a [sua] situação social”. É claramente um enlevo, uma instância não figurativizada da realidade social, e o próprio Ayrton reconhece isso: "Como tal sonho me enchia a imaginação!”.

Importante perceber que a instância imaginativa, representada no livro pela vontade interiorizada de Ayrton Lobo, é de responsabilidade exclusiva do narradorpersonagem. O excerto transcrito permite a constatação de que a teoria das classes "tecnológicas" humanas é criação de Ayrton, viabilizada por sua pura observação

\footnotetext{
${ }^{35}$ A imagem do Cadillac como um carro de ostentação não deixou o inconsciente coletivo mundial desde que o modelo popularizou-se no começo do século XX, sendo lembrada em inúmeras canções, filmes e livros ao longo das décadas seguintes. Jerry Seinfeld, em sua webseries "ambientada" em carros antigos Comedians in cars getting coffee (2018), diz ao comediante Lewis Black, a respeito do Cadillac em que viajarão no episódio (tradução nossa): "Eles [os Cadillacs] mostram tamanha desconsideração por qualquer outra pessoa que não você mesmo! Este carro diz: ‘Estou sozinho no planeta!’”.
} 
empírica, quando saía em serviço e "na rua (...) via a humanidade dividida em duas castas". Ninguém disse isso a ele; tampouco é fruto de leituras ou convicção filosófica, moral, científica ou o que seja.

Esse traço de experimentalismo pessoal, aliás, é, a nosso ver, um dos mais definidores do caráter de Ayrton Lobo. O narrador de $O$ presidente negro preza muito a própria experiência: seja pelo que sofre no trabalho, seja do que observa nas ruas ou o que vivencia no castelo dos Bensons, Ayrton Lobo precisa "ver para crer".

É uma marca distinta das personagens com que deparará adiante. Os Bensons são criaturas da teoria, não pessoas de ação. A prática é com Ayrton Lobo, que, não por acaso, será o narrador da história em livro: ou seja, é ele quem "concretizará" as previsões e acontecimentos do futuro, via um objeto material, físico, como o carro que lhe atiça a cobiça: um livro. A condição (e condução) da história em livro, e o que disso se depreende e dispõe, será matéria tratada páginas adiante.

A imaginação é uma instância que não respeita regras naturalísticas ou dela faz pouco caso. Ayrton, enquanto ainda "pedestre", já se sente, pela vitória virtual de sua percepção onírica, superior aos demais pedestres: pelo poder de sua imaginação, Ayrton virtualizou-se um "rodante". Daí sente-se no direito de comparar seus "irmãos [pedestres]" a formigas, que ele, ao "mudar de casta", deixaria igualmente atônitos e assombrados ao buzinar seu automóvel. Rei de uma pequena instância mental, o narrador já faz planos punitivos para quem não sair de seu caminho (ou de seu carro): o esmagamento.

A instância da realidade, de que trataremos a seguir, tem com a instância imaginativa a relação da água com o óleo: podem estar juntas, como de fato estão reunidas numa mesma personagem, Ayrton Lobo; mas não se misturam. Entenda-se: Ayrton enquanto personagem e Ayrton enquanto narrador possuem configurações diferentes muitas vezes. Então as dosagens de "sonho" estão mais potencializadas, é evidente, na instância de imaginação. Narrado em primeira pessoa, $O$ presidente negro é repleto de cogitações, palpites e comentários de todo naipe, advindos do narrador imaginativo e imaginoso que é Ayrton Lobo.

Atentemos, então, à descrição do acidente feita por esse narrador de imaginação:

"Por essa epoca um dos meus patrões encarregou-me de liquidar pessoalmente certo negocio com um freguês morador perto de Friburgo.

Muito facil me seria lá ir de trem, mas um rodante da minha marca sorria dos trens. Fui no meu auto, apesar das ruins informações que me deram do caminho. Meti boa reserva de gasolina e atirei-me qual um doido por estradas 
de tropa em que, suponho, nenhum automovel ainda se arriscara a passar. Numerosos contratempos sofri nessa minha 'viagem a Damasco', mas mesmo assim tudo acabaria sem novidade se a estrada infame não desembocasse de improviso numa otima, recem-feita e tão bem conservada como a melhor das pistas de corrida. Mal me vi naquele setimo céu de macadame, dei toda a força á maquina e desforrei-me da lentidão de até ali com uma chispada a 60 por hora, o maximo que o meu fordinho permitia.

A região que eu atravessava era de maravilhosa beleza. Serras azues ao longe, quais muralhas de safira a sopesarem um céu de cobalto. Dia de limpidez absoluta. Paisagem das que vibram de nitidez. Desafeito aos formosos quadros da natureza, distrai-me com a novidade do espetaculo e... cataprus!" (1967: 133-4).

Ultrapassada a virtualidade que mencionamos, Ayrton, de posse de seu Ford, é já um rodante, para quem o automóvel tudo resolve ("um rodante da minha marca sorria dos trens"). Em seus delírios de grandeza, o narrador exagera grandemente seus feitos: acredita que "nenhum automóvel ainda se arriscara a passar" por onde dirigia; encara como aventura o cotidiano de rodagem, comparando a estrada conservada à "melhor das pistas de corrida" e transformando seu passeio prosaico numa parabólica "viagem a Damasco", uma marca de significação bíblica, referente à viagem de Saulo ordenada por Jesus - cujo exotismo parece, aos olhos do imaginoso Ayrton, digno de um volume da série Tarzan, de Edgar Rice Burroughs ${ }^{36}$.

\subsubsection{REALIDADE}

A segunda instância envolve a maior parte do relato, quantitativamente falando, pois sua âncora estrutural. É a que denota a ambientação, as peripécias de Ayrton Lobo enquanto hóspede dos Bensons, os conflitos com seus empregadores. É a instância cujos resultados mais refletem nos outros e geram consequências. Quando Ayrton bate o carro, nos seus delírios de grandeza burguesa, sai da instância imaginativa e, ferido, necessita ajuda real, sendo resgatado no castelo do professor.

A instância da realidade é o esqueleto da trama maior de $O$ presidente negro. $\mathrm{O}$ andamento do acidente de carro de Ayrton Lobo, diferente fosse, daria outra história. Consideremos que ele fosse resgatado por alguma autoridade rodoviária ou um particular:

\footnotetext{
${ }^{36}$ O Lobato editor lançou a coleção do homem-macaco de Burroughs e chegou a traduzir duas de suas aventuras: Tarzan no centro da Terra e Tarzan, o terrível. Outros notáveis tradutores da personagem para a casa editorial de Lobato à época incluem o poeta Manuel Bandeira e o mais frequente correspondente lobatiano, Godofredo Rangel. Para o último, Lobato chega a comentar em correspondência de 1926 (mesmo ano de $O$ presidente negro): "Conheces a série Tarzan? Curiosa e bem infantil. Anda em milhões. Eu me acho capaz de escrever para os Estados Unidos por causa do meu pendor para escrever para as crianças. Acho o americano sadiamente infantil" (2010a: 514). Edgard Cavalheiro aponta, entre projetos de séries e livros que Lobato tinha em mente e não chegara a produzir, "uma série como a de Tarzan” (1955: 555).
} 
daí seguiria a um hospital ou casa de repouso e então estaria de volta ao trabalho de sempre, com a diferença de agora não ter mais carro, destruído na batida.

Mas a "realidade", que também é casual, fez com que o acidente se desse próximo à propriedade do professor Benson, o que ocasiona o conhecimento de ambos os homens, a introdução da filha, a revelação das teorias sobre o futuro e a apresentação do inaudito porviroscópio.

As características da realidade moldam o que dela seguirá. Não interessa aqui a imaginação, pois ela não traz efeitos naturalísticos. Ela ainda se faz presente, conquanto não tenha o condão de modificar os estados: é a imaginação de Ayrton que, na ignorância das novas formas e procedimentos com que depara no impressionante castelo dos Bensons, o faz idealizar o que vê, romantizando o que não entende, quase como faziam na origem dos tempos os homens que explicavam por mitos e lendas as origens das coisas e da natureza.

Ayrton Lobo, dessa forma, vê o surgimento de um novo mundo diante de seus olhos e tenta organizá-lo e lhe dar sentido. Logo que chega ao lar dos Bensons procura entender a disposição de (para ele) tão estranho local:

\footnotetext{
"Pela primeira vez depois de recolhido áquela mansão punha eu o nariz fora do meu quarto de doente.

Senti-me surpreso. A casa do professor Benson não era ao tipo de casa vulgar. Dava antes ideia de uma especie de castelo, não pelo estilo, que não lembrava nenhum dos castelos clássicos que eu vira reproduzidos em cartões postais, mas pela massa e o estranho da construção. Olhei para aquilo com marcado espanto. Além do corpo fronteiro, evidentemente moradia familiar, erguiamse pavilhões, galerias envidraçadas e varios minaretes altissimos, ou, melhor, torres de ferro enxadrezado, entretecidas de fios de arame.

—Que diabo de casa é esta? perguntei ao criado, voltando-me para ele" (1967: 137-8).
}

A instância imaginativa falha em dar todas as respostas que procura, pois passamos a uma nova realidade material. Ayrton julga-se num fantasioso castelo, que, por falta de termo melhor, é a designação que dá ao lugar de que desconhece as características de funcionamento. "Castelo", destarte, configura-se como um vocábulo de que o imaginativo Ayrton se vale para classificar algum grande imóvel que se lhe afigura esquisito; não o faz por qualquer semelhança arquitetônica, "mas pela massa e o estranho da construção".

É uma ilustração adequada da reconfiguração das instâncias na organização textual do narrador de $O$ presidente negro. Sendo a instância imaginativa a mais primitiva, é ao mesmo tempo a que possui menos ferramentas para o aclaramento "real" dos fatos e 
acontecimentos e a que possibilita, pelo enraizamento no inconsciente psicológico da personagem, a construção de suas percepções de realidade e observação. Tal como uma criança, que descobre os nomes dos animais pelos ruídos que eles produzem (um cachorro é um "auau”), Ayrton Lobo define uma nova e insólita construção como um "castelo" suas noções de faz-de-conta remodelam o mundo naturalístico com que depara.

Podemos entender que a imaginação, ou a instância imaginativa, é uma preparação para a realidade, ou para a instância real. Em um dado muito revelador de seu caráter, Ayrton Lobo age como alguém que antes de mergulhar numa piscina coloca a mão ou o pé na água: procurando "racionalizar" - ou mais propriamente raciocinar de modo antecipatório -, a ideia consiste em não se imergir prontamente em um ambiente diferente do seu, aos poucos tentando acostumar-se.

No caso do castelo, procura descrever o que vê diante dos olhos e só então concluir algo. Como as informações que encontra são algo confusas e embaralhadas (arquitetura gótica e árabe, por exemplo), o rapaz sente-se incapaz de afirmar com segurança onde está, e precisa pedir auxílio a um empregado do local.

A instância da realidade ressente-se, portanto, de uma incompletude inerente a Ayrton Lobo enquanto personagem e enquanto "pessoa". Ele não dispõe de um corpo de informações eficiente e inquestionável, e as razões são múltiplas: desconhecimento factual do que o cerca, ignorância acerca de coisas nas quais nunca cogitou pensar, defasagem cultural ou intelectual (ao menos se comparado aos Bensons, seus anfitriões), predomínio da imaginação criativa ou sonhadora (em detrimento da prática) em seu espírito etc.

Pode-se vislumbrar um estratagema literário de Lobato: sendo sua personagem o próprio narrador, “dosar em pílulas” suas descobertas revela-se um procedimento textual para criar suspense. Caso Ayrton não descrevesse o castelo de modo quase contraditório e paradoxal, o leitor não acharia estranho o lugar e nem ficaria apreensivo quanto ao futuro de Ayrton e os rumos da história.

Para os Bensons, seu lar nada oferece de misterioso; se um deles narrasse $O$ presidente negro, a técnica exigida e os efeitos dela decorrentes seriam deveras diversos. Quando muito, encontraríamos uma narrativa insólita, mas o aprofundamento do mistério só é possível a alguém que vê ou cria o mistério dispondo de boa medida de incompreensão, que se relaciona plenamente com a instância da realidade (em que Ayrton tenta entender com seus sentidos o entorno e falha), e de imaginação construtiva, que faculta ao leitor a capacidade de se maravilhar e espantar junto com o narrador- 
personagem - alguém que experimentou talvez suas mesmas emoções de choque até elucidar-se o quadro geral.

Em última análise, o narrador do romance já passou por essas situações. Mas a técnica de Ayrton Lobo (e de Lobato) funda-se em uma recorrente retomada de estados iniciais. Quando o narrador descreve o castelo em que foi alojado, não o faz com a sapiência adquirida ou o calmo exame da situação a posteriori. Do mesmo modo, quando descreve a primeira vez que vê as personagens, ou o caso do acidente automobilístico, é quase como se o narrador revivesse os eventos e fosse conhecendo sua real natureza junto a nós leitores.

Evidentemente isso se relaciona com a estrutura de um romance, com os eventos sendo determinados de maneira próxima ou pouco distanciada, para criar efeitos junto a seu público, que ficará em suspenso até saber o desfecho de uma dada situação, acompanhando o lento desvelar das ocorrências da história.

Consideremos a estrutura geral de funcionamento dos aspectos receptivos do romance junto ao seu leitor como pensada por Antonio Candido:

\begin{abstract}
"O enredo existe através das personagens; as personagens vivem no enredo. Enredo e personagem exprimem, ligados, os intuitos do romance, a visão da vida que decorre dele, os significados e valores que o animam. (...) Os três elementos centrais do desenvolvimento novelístico (o enredo e a personagem, que representam a sua matéria; as 'idéias', que representam o seu significado, - e que são no conjunto elaborados pela técnica), estes três elementos só existem intimamente ligados, inseparáveis, nos romances bem realizados. No meio deles, avulta a personagem, que representa a possibilidade de adesão afetiva e intelectual do leitor, pelos mecanismos de identificações, projeção, transferência etc. A personagem vive o enredo e as idéias, e os torna vivos" (2017: 53-4).
\end{abstract}

Isso se torna ainda mais patente quando falamos de uma obra publicada originalmente em folhetim, caso deste $O$ presidente negro, em que o leitor é convidado a conhecer aos poucos as peripécias das personagens e as descobertas envolvidas no enredo, com os "ganchos" de suspense que costurariam o interesse da trama ao longo das semanas ou meses de veiculação.

Mas não é apenas isso, essa vulgar técnica-base de boa parte dos romances, que faz Lobato descrever as peripécias de Ayrton Lobo dessa maneira. Nossa hipótese é de que a escolha das personagens "ignorantes" ou "sábias", da parte do escritor, tempera-se de modo arguto, visando a usar as vozes e especificidades de cada figura para convencer, provar, questionar os valores e informações que Lobato quer debater ou discutir. 
A instância da realidade é um importante esqueleto estrutural. Relacionando-se a instância imaginativa com o passado - a infância, época de aquisição dos conceitos-base do caráter e das noções que instrumentalizarão as percepções sensoriais e fantasiosas dos indivíduos, é ontologicamente associada a um período mais ou menos específico de anos, nos quais a criança aprenderá a elucidar o mundo que habita; como disse Piaget, "o desenvolvimento da criança é um processo temporal por excelência" (1983: 211) - e a instância narrativa (que discutiremos a seguir) com o futuro, tanto na história como a história em si, a instância real tem relevante papel de instauração das características de um presente, vivenciado pela personagem e descrito pelo escritor a seu público.

\subsubsection{NARRAÇÃO}

É uma instância metalinguística, que gera um "romance dentro do romance". A história que Jane Benson conta a Ayrton Lobo, concernente ao futuro dos Estados Unidos e do mundo, não tem aporte real-materialístico e nem se baseia em sua imaginação ou cogitação. Miss Jane faz as vezes de narradora oculta, espécie de Sheherazade a desvendar o futuro ao atônito Ayrton Lobo.

Como dito no item anterior, a instância propriamente narrativa relaciona-se intrinsecamente ao futuro. Tanto por ser uma história sobre o futuro quanto por ser a parte "suposta" do romance, a mais obviamente ficcional, que pressupõe coisas que não são verificáveis pelos nossos sentidos e nem totalmente compreensíveis com nossa imaginação, pois é a descrição de um mundo imaginativo de outra pessoa (a saber: o escritor). Quer dizer, uma porção do livro cuja autenticidade é exclusivamente devida às personagens, que se responsabilizam pelo conteúdo exposto.

Miss Jane é a personagem responsável por essa instância, indiretamente (pois a narração, mesmo a de Miss Jane, intermediada, é feita em primeira pessoa por Ayrton Lobo). Apesar de não inventar nada, pois a moça não faz mais que relatar cenas vistas no aparelho criado por seu pai, a personagem estrutura sua narração de modo a transformála em uma narrativa.

Falamos de Ayrton "escondendo" do leitor o que, em teoria, já vivenciou e portanto sabe, e Miss Jane reproduz esse esquema de um jeito ainda mais nítido, com verdadeiros "serões" repetidos a cada domingo para inteirar o narrador-personagem sobre tudo que se passou no ano conflituoso de 2228: 


\begin{abstract}
"Falamos depois do nosso romance sobre o choque das raças na America. - Sim, disse miss Jane animando-se. Continuo a pensar que o senhor Ayrton não deve perder a oportunidade. Ouvirá de mim tudo o que sei a respeito e escreverá um livro deveras interessante. Não lhe prometo já, já, fazer essas revelações. Neste meu estado, compreende que me seria penoso. Mas o tempo cicatriza, eu sei, e lá chegaremos. Para mim será até um derivativo á dor da saudade. Dizem que recordar é reviver e eu pressinto que minha vida vai resumir-se nisso: recordar, reviver o que tenho acumulado na memoria. Venha todos os domingos e creia que sua presença me será sempre agradavel — além de que estamos ligados pelo grande segredo" (1967: 198).
\end{abstract}

Importa ressaltar aqui que, como comentamos, a instância da realidade é a que mais gera consequências: é quando o professor Benson destrói o porviroscópio e seus planos que possibilitariam reconstruí-lo, que Miss Jane narra o que ela sabia a seu hóspede. Sem sua experiência pessoal nada do relato seria viável. O empirismo não se adequa à instância imaginativa, vide como Ayrton Lobo, confundindo experiência e desejo no incidente do carro, não foi exitoso em seus desígnios.

Miss Jane constrói seu relato aos poucos, com focos de suspense, ganchos e outros recursos que impedem sua narrativa de ser uma impassível descrição do que ela sabe acontecer no ano de 2228. Consciente de sua "onisciência controlada", deixa Ayrton Lobo ansioso e preocupado em diversas ocasiões: "O ponto e virgula com torradas veio interromper naquele dia as revelações de miss Jane. Retirei-me mais interessado do que nunca no desfecho da crise americana do seculo 23" (1967: 264). O leitor lobatiano compartilhará o suspense e o envolvimento de Ayrton.

A exposição de Miss Jane emula a própria estrutura de folhetim em que $O$ presidente negro a princípio foi veiculado. A toda semana, em seus encontros dominicais, ela adianta um pouco mais da história, que é construída com personagens, doses de excitação em seus desenvolvimentos, lances de cena. Não relata mais que o indispensável, corta a narração no ponto em que lhe parece conveniente.

É um pouco o que faz, numa estrutura diferente ainda que assemelhada, Ayrton Lobo. Sendo o narrador do romance de Lobato, Ayrton é o coordenador de todas as vozes e instâncias narrativas. O próprio romance "em si" nasce como uma espécie de "aposta" com Miss Jane, que diz a Ayrton que ele poderia transformar a insólita experiência que presencia em um imaginoso romance:

“- Esse choque, disse miss Jane, deu-se no ano 2228 e assumiu tão empolgantes aspectos que reduzido a livro dá uma perfeita novela. Não sei se o senhor Ayrton é literato...

— Já fiz um soneto na idade em que todos desovam sonetos...

- Pois se não é poderá tornar-se. O principal para uma novela é ter o que dizer, estar senhor de um tema na verdade interessante. Ora, eu fornecerei os dados dessa novela e o senhor Ayrton terá oportunidade otima para apresentar-se ao 
mundo das letras com um livro que a critica julgará ficção, embora não passe da simples verdade futura" (1967: 182-3).

Detenhamo-nos alguns momentos na apreciação do que Miss Jane diz. Sua aventura, que na diegese do romance é um conjunto real de peripécias, afigura-se-lhe tão incrível que o meio adequado de a transmitir a outrem não é da ordem (ou instância) da realidade propriamente dita ou congênere. Não propõe a Ayrton descrever o caso em um livro de reportagem investigativa ou em matérias para jornal, ambos gêneros que já existiam à época - ainda que, evidentemente, com contornos e definições diferentes dos que hoje conhecemos, devido às evoluções compreensíveis dos gêneros, autores, tendências e escolas.

Miss Jane é categórica em sua sugestão: propõe a Ayrton a escritura de um romance. A qualidade do que se tem a revelar e demonstrar é tão dificilmente compatível com os olhares e sensibilidades contemporâneos, que forçosamente duvidariam do porviroscópio e tudo que lhe era relacionado, que apenas pintando o sucedido com tintas ficcionais o relato seria palatável aos leitores da época de Ayrton (e de Miss Jane).

Esse verdadeiro comando, que faz Ayrton estabelecer um objetivo (escrever um livro) que até então nunca havia lhe passado pela cabeça, é possível porque, como Carlos Minchillo comenta, "a relação de ouvinte e narradora que se estabelece entre Ayron e miss Jane caracteriza-se pela hierarquia entre mestre e aprendiz e confunde-se com um servilismo amoroso" (2014: 199). O narrador-personagem tem um impulso duplo: diminuir ou moderar seu sentimento de inferioridade e conquistar o interesse amoroso da jovem Benson.

Ayrton, que não demonstra em praticamente momento algum ter grandes inclinações artísticas, entusiasma-se com a sugestão. Como insistentemente demonstra ao leitor (e a Miss Jane), possui um rol de citações culturais e bagagem sobre fatos históricos e literários, o que talvez configure especial ironia lobatiana contra um saber "de verniz".

É o que, contudo, acoplado a um forte desejo de impressionar a jovem, basta a Ayrton para convencer-se da viabilidade da construção de um romance sobre o que lhe era narrado e o que de fato presenciou - e chega a empolgado afirmar que "será romance como os de Wells, porém verdadeiro, o que lhe requintará o sabor" (1967: 183).

\subsection{O LIVRO DENTRO DO LIVRO}


O romance passará, então, a ocupar muitos dos pensamentos e cogitações de Ayrton Lobo. Será sua meta futura imediata. Concluir o romance a contento significará, no seu entender, convencer Miss Jane acerca de suas qualidades não apenas artísticas, mas morais, humanas, de pensamento.

Entendemos ser clara aqui a "mensagem" de Monteiro Lobato: um livro não é só um livro. Um livro é um portal que abre o espírito a dimensões variadas de um ser, um tema, uma comunidade. Pelo livro, divulgamos ideias, estabelecemos discussões e planejamos o que fazer daí em diante. O próprio Lobato deu o exemplo com Urupês, seu primeiro passo na celebridade e relevância cultural - o volume reunia não apenas contos e histórias esparsas, mas convites à reflexão e polêmicas que tinham, em última instância, o intuito de denunciar males contemporâneos para que se lhes buscassem soluções reais: queimadas, parasitismo social, deficiências sanitárias no meio rural.

Miss Jane não quer nada prático de Ayrton Lobo. É a ausência de metas objetivamente realizáveis de imediato que exaspera o narrador, inclusive; Miss Jane, a seu ver, distancia-se do "coquetismo" feminino, o que lhe deixa inconfessadamente sentindo-se inferior intelectualmente: "Fui percebendo aos poucos que de feminino só havia em miss Jane o aspecto. Seu espirito formado na ciencia e seu convívio com um homem superior, dela afastavam todas as preocupações de coquetismo, proprias da mulher comum" (1967: 170).

Nesse sentido, o romance a ser escrito também é um ajuste consigo mesmo: mostrar a aptidão para competir intelectualmente com jovem tão instruída e impressionante. Como se fizesse uma aposta consigo próprio, Ayrton Lobo quer equiparar-se em brilhantismo aos Bensons, que foram capazes de observar o futuro. Ayrton, o narrador das aventuras em livro, é quem, ironicamente, as tornará plenamente alcançáveis no futuro, pois positivá-las-á, ao escrevê-las.

A jovem Benson, que conhece muito do futuro, repleto de dispositivos e maquinaria virtualizados, que dispensam o uso de papel $^{37}$, não se opõe a ter sua história passada em livro, ao contrário: ela também, como Ayrton Lobo, demonstra entusiasmo pelo projeto do livro, ao qual alude várias vezes e afirma que "sairá uma novela única no gênero" (1967: 183).

\footnotetext{
${ }^{37}$ Vide esta curiosa descrição do método de confecção jornalística do rádio-transporte: "Cada colaborador do Remember [jornal] radiava de sua casa, numa certa hora, o seu artigo, e imediatamente suas ideias surgiam impressas em caracteres luminosos na casa dos assinantes" (1967: 236). O método descrito assemelha-se muito ao que hoje conhecemos como internet.
} 
A metalinguagem de Lobato, no entanto, é labiríntica. Nada garante que Ayrton Lobo esteja sendo fiel aos fatos que presenciou - ou diz ter presenciado, pois nem disso temos certeza. Como bom narrador em primeira pessoa, suas informações devem passar por saudável controle de descrença, que colocará em xeque aos olhos do leitor as informações que lhe são passadas.

Não entraremos em considerações a respeito da própria estrutura da narração personalizada, por exemplo indagando como a personagem teria memória tal para narrar os diálogos que ouviu (ainda que Ayrton garanta que as coisas o impressionaram tanto que ele as recorda intensamente); o que queremos expor aqui é a narração dentro da narração, algo próximo das histórias lendárias das mil e uma noites. Esse arranjo permite alguma inferência na questão realidade versus ficção.

O quadro geral (ou a história "moldura", para usar um termo bem do gosto dos estudiosos das histórias árabes ${ }^{38}$ ) é narrado por Ayrton Lobo, a personagem que, "factualmente", narra todas as instâncias e transcreve todos os diálogos e vozes de $O$ presidente negro. Quer dizer que, na ordem do romance, toda palavra foi coletada, transposta e escrita por Ayrton. Quando Miss Jane fala, ela fala "através de Ayrton", por meio de sua pena. Poder-se-ia acreditar, por exemplo, que se Miss Jane contasse a Ayrton algo que ele não compreendesse essa informação apareceria de algum jeito adulterada no relato escrito pelo narrador.

É confuso, mas necessário para nosso estudo, embrenhar-se nesse esquema de instâncias narrativas e de personagens. Monteiro Lobato está diluído sob várias formas nas esferas ficcionais dessa obra. Cabe sondar até que ponto Miss Jane é Ayrton Lobo e o quanto Ayrton tem de Lobato. Por que algumas ideias encontram em algumas personagens ressonância, em outras, resistência, em outras provoca questionamentos? Essa investigação é, afinal, um de nossos principais objetivos.

Retomando a análise da metalinguagem do livro, é nesse objeto material que Jane Benson, a jovem que tem "as chaves do futuro", pretende que se registre toda a descrição do que ela e seu pai descobriram. O livro é o passaporte seguro para a informação circular. A ressalva que a moça faz é que na era contemporânea a menção às coisas do futuro causa espanto e perturbação, daí melhor revesti-las com ficcionalidade.

\footnotetext{
${ }^{38} \mathrm{O}$ termo é usado confortavelmente, entre outros, pelo único tradutor direto do árabe para o português da integralidade do Livro das mil e uma noites, Mamede Mustafa Jarouche (2006). Lobato cita As mil e uma noites, um interesse constante seu, no capítulo VIII de O presidente negro.
} 
Novamente, é difícil não reconhecer Lobato aqui, o escritor que durante boa parte de sua vida e obra foi reconhecidamente um cultor de "dizer verdades" por forma ficcional: denunciando o atraso social dos caipiras em seus contos, dizendo postulados irreverentes pela boca de Emília etc.

Ou seja, o estatuto de ficcionalidade não impede o estatuto de verdade. É uma forma um tanto utilitarista de enxergar a literatura, ainda que feita de maneira exemplarmente cifrada e literária. Monteiro Lobato, aqui podemos dizer com bastante segurança, a vida inteira lutou para imprimir em seus textos ficcionais marcas do que acreditava, no que julgava talvez o meio mais aprazível para difundir ideias instrutivas.

E, consideremos, o meio mais certeiro igualmente: com suas campanhas de ampliação de parques gráficos, difusão massiva de livros e conscientização da importância da leitura, Lobato sabia ter nos livros uma plataforma grande e extremamente útil para a veiculação de seus princípios.

Não é, portanto, acidental a discussão do "livro dentro do livro" em $O$ presidente negro. Não apenas porque, em último caso, o livro dentro do livro é o próprio livro, como porque, pelo que expusemos, a Lobato o livro importava mais que outras mídias e plataformas $^{39}$.

Daí a preocupação final de Lobato no término de seu livro: o livro. Miss Jane faz no último capítulo uma verdadeira poética da literatura, que reflete os anseios e a profissão de fé de Lobato:

“- Que vaidosos os moços! Lembre-se de meu pai. Quantas vezes fazia e
refazia a mesma experiencia, com uma paciencia de beneditino! Por isso
venceu. Lembre-se do esforço incessante de Flaubert para atingir a luminosa
clareza que só a sábia simplicidade dá. A enfase, o empolado, o enfeite, o
contorcido, o rebuscamento de expressões, tudo isso nada tem com a arte de
escrever, porque é artificio e o artificio é a cuscuta da arte. Puros maneirismos
que em nada contribuem para o fim supremo: a clara e facil expressão da ideia"
(1967: 327).

O Lobato pré-América (que ainda não viajou aos Estados Unidos) não quer apenas "brincar com o estilo", posição manifestamente contrária a seu espírito de escritor que acredita na comunicação direta de ideias.

\footnotetext{
${ }^{39}$ Anos depois, em América, Lobato/Mister Slang explica por que acredita que o cinema, que vinha sendo enxergado como a mais "completa" das artes (pois detentor de som, texto e imagem), não poderia alçar tão altos voos e estava sendo utilizado abaixo de suas potencialidades (a principal culpada era a censura nesse meio). Mais um indício das contradições lobatianas: apesar de considerado invenção francesa, o cinematógrafo foi tido depois como a mais americana das formas de entretenimento ao longo do século XX; e justamente ele é "rebaixado" por Lobato em sua descrição deveras entusiasmada de turista americano.
} 
O autor continuaria a pensar assim durante toda a sua vida, vide o que disse em seu famoso prefácio para o Éramos seis de Maria José Dupret, publicado em 1943, pouco após criticar o "excesso de perfeição estilística" (2009c: 56) na literatura: "E a gente fica a pensar numa coisa tremenda: se a 'literatura' não é a grande desgraça da literatura!..." (2009c: 61).

Lobato dosa os constituintes literários com a praticidade que a convicção de seus postulados lhe agrega. E por meio de suas personagens, que conhecerão, refutarão ou acatarão suas visões de mundo, o escritor participa ao leitor sua empolgação com a América e as possibilidades de tecnologia e progresso advindas do ideal americano.

As previsões, suposições e esperanças de Lobato ficam demarcadas pelo livro de Ayrton, do mesmo modo que as previsões, suposições e esperanças de Miss Jane e Ayrton se intercambiam nos relatos e experiências trocados entre si. A ficção científica de Monteiro Lobato funda-se em sonho, mas sonho de suas personagens, que desenvolvem seu mesmo discurso, sob variadas chaves de compreensão e aprofundamento. 


\section{MISTER SLANG NO BRASIL E FORA DELE}

\subsection{UM PAÍS A SER MUDADO DE DENTRO PARA FORA: MISTER SLANG E $O$ BRASIL}

\subsubsection{SURGE MISTER SLANG}

Em 1926, o recém-empossado presidente Washington Luís, acreditando que Monteiro Lobato seria um interessante agente em prol dos interesses da indústria nacional e da cultura do Brasil, convida-o para ser adido comercial em Nova Iorque. Edgar Cavalheiro anota que o próprio Lobato afirma que "Washington Luís propôs mandá-lo para algum pôsto fora do País, não só para evitar qualquer incidente, mas também para que, lá fora, se convencesse de que o Brasil não era tão ruim como êle dizia" (1955: 356). O escritor aceita sem mais hesitar e embarca com sua família, chegando a Nova Iorque em princípios de junho de 1927.

Nos meses antecedentes de sua viagem, fascinado com a organização americana, Lobato escreve, para o periódico 'O Jornal', de Assis Chateaubriand ${ }^{40}$, uma série de colóquios entre duas personagens fictícias: um certo Mister Slang, britânico, e um brasileiro, jamais identificado propriamente, que narra e transcreve os diálogos. Trata-se de curtas e mordazes reprimendas ao que no Brasil se faz de errado e ineficiente, em termos de sociedade, política e economia, em contraposição principalmente ao modelo americano, descrito entusiasticamente como mais evoluído e proveitoso.

Curioso notar que as críticas aos procederes brasileiros se dá, nesses tempos americanos de Lobato, não por um americano, e muito menos por um brasileiro, e sim por um inglês. Um "inglês da Tijuca", afastado de Lobato em língua, nacionalidade e localização mesmo no Brasil. A preocupação de distanciação com esse alter ego é tanta que na obra que compila suas primeiras "aventuras", Mister Slang e o Brasil, Lobato escreve uma breve e irreverente biografia apresentando ao leitor a intrigante personagem:

"Quem é este Mister Slang?

John Irving Slang nasceu na cidade de Hull, em 1872, e fez estudos em Cambridge. Muito jovem ainda deixou a ilha e partiu a correr o mundo, ganho de uma insaciável fome de pitoresco. Esteve na Índia, na Nova Zelândia, nas

\footnotetext{
${ }^{40}$ Chateaubriand assume a chefia de 'O Jornal', fundado cinco anos antes, em 1924. O periódico sobreviveu a sua morte em 1968, sendo encerrada a publicação seis anos depois. 'O Jornal' foi bastante relevante no contexto da renovação editorial jornalística empreendida por "Chatô", sendo um dos embriões dos poderosos Diários Associados.
} 
Ilhas Salomão, no Havaí, em Sarawak e outras inconcebíveis terras de gente cor de pinhão. Por fim veio ao Brasil, onde encalhou por quarenta anos no mais lindo bangalô do Alto da Boa Vista.

Absorveu-se em estudos das nossas coisas, depois que se retirou dos negócios, cheio de libras e notas da extinta Caixa da Conversão - a qual o bigodeou indecorosamente, seja dito de passagem" (2008a: 21).

Mister Slang e o Brasil tem uma estrutura consideravelmente simples e bastante nítida. Composto por capítulos curtos representando, cada um, um comentário sobre um ponto específico da deficitária realidade brasileira (como câmbio, imigração, taxação), são essencialmente historietas desenvolvidas por diálogos entre dois interlocutores, como previamente referido: Mister Slang e um seu amigo brasileiro, que discutem e fazem comentários ligados ao "senso comum" (dos leitores e dos brasileiros), enquanto jogam xadrez, passeiam e se ocupam dos afazeres cotidianos.

O brasileiro é desinformado, de pensamento simplório e bastante reticente frente à retórica e ideias do britânico. De iniciativa tíbia, muitas vezes receia se expressar, demonstra apaixonado fascínio pelas teorias do amigo e age evidentemente de contraponto para a personagem-título apresentar seus raciocínios. Suas participações são bem marcadas: servem para avançar as teorias do comparsa inglês, para pontuar alguma ideia que deve ser negada, e até como alívio cômico, por sua caricata desinformação, volubilidade opinativa e reações emocionais aos problemas que lhe são fria e calculadamente apresentados.

Mister Slang é construído por Lobato como um observador “idôneo". Está no Brasil há quatro décadas, pouco menos que a idade de Lobato - pode-se inferir que Lobato o retrata quase como alguém com experiência em coisas do Brasil superior à sua (ou quase tão abalizada e digna de confiança). É portanto um avatar de respeito, sem satirismo, feito de modo a nem sequer apresentar uma "reverência" demasiada: Mister Slang não é humoristicamente a apologia de um "mundo ianque", mas um sensato inglês que aponta nossas imperfeições brasileiras ${ }^{41}$.

\subsubsection{EXEMPLOS DE QUEM "DEU CERTO”}

O remédio para os males do país, o que nos diz o discurso, deve ser mudar o rumo das coisas. O narrador brasileiro - como de resto todo o Brasil, parece dizer Lobato - é incapaz de entender a dinâmica das coisas que atrasam seu país. Mister Slang, então, por

\footnotetext{
${ }^{41}$ Analisaremos no último capítulo a construção de Mister Slang como avatar e os efeitos de sua retórica nos planos de Lobato e na estrutura das obras em que aparece.
} 
meio de curtas e engenhosas explicações, e farto apoio de parábolas e metáforas, convida a uma mudança de pensamento.

O livro entra em uma chave que talvez seja sua razão maior de existência: a definição teórica de um “outro Brasil”, nos moldes do que Mister Slang considera justo e acertado para o progresso do país em que está. Esse novo Brasil se assemelha em muito aos Estados Unidos que empolgavam Monteiro Lobato no período, e Mister Slang não se recusará a apontar os caminhos que considera oportunos:

\footnotetext{
"Mister Slang tomou fôlego. Depois disse:

- Há de haver uma causa para que o Brasil, com o seu imenso território e os seus trinta milhões de habitantes, seja um dos países mais pobres do mundo.

— Talvez que a gente não preste... - ia aventurando eu. Mas Mister Slang tapou-me a boca:

- Depois que Henry Ford demonstrou como se aproveitam até cegos e aleijados, ninguém tem o direito de alegar o que não presta. Tudo presta. Até um cego, um estropiado presta. A questão toda está em proporcionar-lhe condições para prestar. O mesmo cego que aqui não presta para coisa nenhuma em Detroit produz igual a um homem perfeito e ganha 6 dólares diários. O brasileiro precisa de condições para prestar - e a condição número um é a fixidez da medida do valor, a moeda" (2008a: 42).
}

Mister Slang não inventa seu otimismo, pois não é otimista: é pragmático. O exemplo foi dado por outro país, um país que funcionou, que tem um homem de visão (Henry Ford) a aproveitar a eficiência dos trabalhadores em máxima escala. Trata-se de aproveitar-se o que se tem, para os fins possíveis.

Interessante observar que o brasileiro, amigo e discípulo do inglês da Tijuca, faz as vezes do "desistente", desertor do que se pode fazer para seu próprio país melhorar. Acredita em teorias científicas ultrapassadas, presumivelmente: a de que gente dos trópicos não presta, não sabe trabalhar, não alcança grandes resultados pois nasceu fadada a pequenas realizações, por conta do clima e de sua constituição física e cultura.

Os valores de Mister Slang, por outro lado, são despersonalizados. As trinta milhões de pessoas que habitam o Brasil de então "prestam", mas não são individualizadas, talvez nem individualizáveis. São trabalhadores, peças que podem ser usadas para o progresso do país, nos moldes da linha de produção fordista. Dadas as “condições para prestar", todas as trinta milhões de pessoas, espalhadas no gigantesco território brasileiro, podem servir ao conserto do que ora está desarrumado.

No entanto, há um entrave para isso, o que Mister Slang mais criticará ao longo dos colóquios: a ação dos políticos, ou melhor, a inércia dos homens públicos, a ignorância dos poderosos, os arranjos dos burocratas. A moeda, por exemplo, não se fixa 
por problemas que podem ser contornados e compreendidos por todos, como o inglês da Tijuca passará a demonstrar a seguir:

“-Estou compreendendo, Mister Slang. O câmbio, o cambista, o homem que desconta os vales do governo impontual, só aparece quando o emissor do vale foge ao seu pagamento...

- Isso mesmo. Mas esse particular que desconta os vales do governo está claro que o faz para ganhar dinheiro, e nunca paga o vale pelo valor nominal. Paga o que no momento lhe convém pagar, $10 \%, 30 \%, 50 \%$ ou $60 \%$ do valor niominial, conforme a taxa de câmbio, isto é, conforme todos quantos fazem esse negócio de desconto acham que nesse momento devem pagar.

- Quer dizer que câmbio, isto é, desconto de vales do governo por particulares, só existe quando o governo não paga fielmente os vales que emite?

- Claríssimo! Desde que o emissor dos vales cumpra o seu dever, a sua palavra, a sua promessa, extingue-se a classe dos descontadores de vales, dos cambistas, dos que vivem à sombra e como produtos lógicos da desonestidade dos governos.

- Estou entendendo. E também compreendendo as razões do clamor contra a estabilidade..." (2008a: 37).

O narrador brasileiro desconhecia os meandros dos fatos expostos por Mister Slang (“quer dizer que...”), que explica a situação com eficácia e torna o motivo "claríssimo" ao amigo, que, finalmente, passa a "entender" a questão. E não só entende por que a moeda não se fixa (não fica estável), como entende por que a não querem fixar (“o clamor contra a estabilidade"): má utilização dos fundos públicos, ineficiência administrativa, gestão deficitária.

Mister Slang fala por Lobato quando louva Henry Ford, “esse genial reformador da indústria” (2008a: 87). Sem muito disfarce na defesa dos ideais fordistas, Slang-Lobato elogia a organização das empresas de Ford, considerada exemplar, sua visão de trabalho e eficiência, o esquema distributivo de funções. Para Ford, Mister Slang e Lobato, "não há trabalho mais nobre ou menos nobre. Há trabalho, apenas. Varrer ou desenhar plantas: tudo é trabalho" (2008a: 87).

Um ponto importante de Mister Slang e o Brasil é que não sendo "explícita" a apologia de Lobato aos Estados Unidos, o escritor tenta dar exemplos universalizantes ou que abrangem outras perspectivas. Para comentar a situação das indústrias brasileiras o exemplo é dado com um país fronteiriço ao nosso, ao qual já aludimos:

“- De modo que para Mister Slang as nossas indústrias protegidas constituem um mal... Mas não negará que muito nos serviram durante a conflagração européia.

- Ponto a discutir. Mas dou de barato que assim tenha sido e pergunto se é argumento sério. Conservar no organismo uma ordem de coisa viciosa, que o debilita, que o mata, só porque num eventual caso de guerra possa tornar-se um momentâneo bem, será fórmula defensável? Faz-me lembrar um homem que andasse léguas e léguas descalço, a ferir as solas nas pedras do caminho, 
só para beneficiar-se com a frescura da água de um riacho eventual que tenha de passar a vau. A Argentina, que não tem indústrias falsas, não se arrumou perfeitamente durante a conflagração? Não saiu ganhando, não está mais próspera do que nunca, ao passo que o Brasil geme no atoleiro, enterrado até ao nariz?" (2008a: 70).

Ainda que não seja o escopo deste trabalho falar da admiração de Lobato pela terra argentina, cabe, para complementação das ideias aqui desenvolvidas, determo-nos um pouco no fenômeno ${ }^{42}$.

A Argentina, sob certo prisma, era o exemplo mais próximo do que Lobato idealizava, guardadas as proporções com o caso americano. O país vizinho ao Brasil configurava-se assim como um "Estados Unidos da América do Sul”. Vimos no capítulo anterior que ele também dá o exemplo argentino para falar do voto livre, das eleições democráticas, um exemplo de país que "deu certo" pois usou adequadamente o processo tido por correto.

Assim, que não se estranhe Lobato voltar à carga. E nem Mister Slang, que não se considera um defensor ou apologista dos Estados Unidos, mas um homem que tem lucidez para entender os eventos que levam a desmazelos e que pode criticá-los com embasamento e aproveitamento.

Isto é, tanto faz se o exemplo funcionou nos Estados Unidos ou na Argentina: o Brasil aqui é o errado, defasado, incorreto; siga-se o modelo adotado por quem acertou e acertar-se-á também.

Repare-se também como o discurso de Mister Slang, e o de Lobato, visam ao convencimento por meio da utilização de imagens simples, compreensíveis a todos, do interlocutor brasileiro do inglês aos leitores de Mister Slang e o Brasil. As indústrias deficitárias brasileiras são tratadas como uma doença que não sai do organismo vivo do país, uma ideia forte e inteligível a todos, irmanada ao quadro que tornou Lobato célebre com a descrição do Jeca Tatu em Urupês. Uma espécie de "doença de estimação", que a falta de comprometimento com os bons valores (sanitários, no caso do Jeca, políticosociais, no caso das indústrias) vai perpetuando, terminando por deixar a cena quase natural àquele ente. "Conservar no organismo uma coisa de ordem viciosa".

\footnotetext{
${ }^{42}$ Na biografia lobatiana a Argentina tem um papel proeminente sobretudo no fim de sua vida: exilado, por conta própria, do país após a vitória de Eurico Gaspar Dutra, candidato "avalizado" por Getúlio Vargas, desafeto do escritor, Lobato decide passar uma temporada com a família na Argentina. Lá se envolve em atividades editoriais e lança com noticiado sucesso vários de seus livros, sobretudo os infantis. Além dos Estados Unidos, a Argentina é a única outra terra estrangeira por onde Lobato passou e residiu.
} 
Também o inglês faz parábolas e metáforas com frequência, ilustrando o que disse com comparações simples. No excerto transposto, fala de um viajante que machuca os pés sem qualquer promessa de que seu desejo terá satisfação. Mister Slang diz que o viajante é o Brasil, e o desejo sem expectativa é o do funcionamento de suas indústrias. Para ele, confiar nas problemáticas indústrias brasileiras equivale à eventualidade de deparar com um arroio, andando a esmo numa jornada sem planejamento (o viajante está descalço e sedento).

Deveras surpreendentemente, será Mister Slang quem injetará no desanimado amigo brasileiro a crença de que para consertar o Brasil e equipará-lo às nações que deram certo precisa-se antes deixar de descrer no país:

“- Já vimos o que isso vale e não consigo admitir que certas medidas de simples honestidade só possam ser aplicadas na América do Norte. Apesar de britânico, vejo o Brasil com melhores olhos do que a maioria dos brasileiros. Noto entre vocês uma descrença excessivamente generalizada.

- E temos razão para isso - gemi (...).

- Terão razões, mas não terão o direito de descrer do país. A boa vontade e o amor ao bem público operam prodígios.

- Sei disso. Mas a nossa mentalidade política se divorciou demais do bem público. Perdeu-o de vista. Só enxerga o bem pessoal.

- Não comparticipo dessa descrença, meu amigo. Basta que um homem no alto creia no bem público para que os maiores milagres se operem. E isso é mais fácil no Brasil do que em qualquer outra parte, uma vez que a forma real de governo aqui é a de uma perfeita ditadura sob aparências constitucionais.

- Fácil dizer, Mister Slang. Os óbices são tremendos...

— Mas não insuperáveis. Não há óbices insuperáveis para a boa vontade. E eu já noto por cá um começo de reviravolta na mentalidade" (2008a: 116).

As razões para o desânimo são profusas, e Mister Slang deter-se-á em várias delas. No entanto, lastimar-se não significa nem agrega coisa alguma ao problema, antes o torna estático. Daí os apelos aos ideais sentidos pelo inglês e por Lobato: a boa vontade, um homem justo e de visão, o valor do trabalho, do empenho pessoal.

O Brasil, graças aos brasileiros, pode subir. A honestidade não existe apenas na América do Norte, vide o caso argentino. A desconfiança excessiva, no entanto, emperra os desejos de mudança, como se não valesse a pena considerar os problemas e tentar solucioná-los. Contra isso Mister Slang se coloca.

\subsubsection{BRASIL, UM PAÍS ERRADO}

O Brasil que Lobato apresenta e Mister Slang comenta em Mister Slang e o Brasil é um país raté, que deu errado, fracassou. Que pode ter esperanças e saídas para suas 
mazelas, mas não as vê nem aproveita as oportunidades. É um cenário de crise, portanto. Crise sobretudo econômica. O inglês coloca as coisas em perspectiva deste modo:

“-Esquecem-se de que, avariado e a fazer água como está o navio, torna-se duvidoso que alcance tais latitudes...

- É concertá-lo, tapar a água até que o navio lá chegue.

- Mas se justamente o balouço excessivo da nau é o que impede os reparos, homem! Dizem uns: primeiro equilibrar os orçamentos, primeiro fazer a paz. Mas o desequilíbrio financeiro é em grande parte efeito da instabilidade.

— Mister Slang não irá dizer que a revolução também procede da instabilidade. — Não vou dizer? Digo já, pois toda revolução tem como causa última o malestar econômico. País que prospera não faz revoluções. Equilíbrio de orçamento! Como, se a moeda é móvel? Como organizar um orçamento de despesas, se parte delas é em ouro e no fim do ano o ouro pode estar valendo o dobro ou a metade? Tolices, meu caro. Chicanas. A base de tudo é a fixidez. Primeiro, estabilize; depois faça o que quiser. Estabilize, e o problema financeiro se resolverá por si mesmo. Estabilize, e a revolução perderá a sua razão de ser" (2008a: 41).

A instabilidade política - as revoluções, como as do tenentismo, as revoltas populares e todo o caldeirão de causas do fim do que hoje chamamos República Velha, que tiraria Washington Luís da presidência em poucos anos e instauraria a Era Vargas e as mazelas sociais são, diz Mister Slang, frutos de uma única ou maior causa: o desarranjo econômico. "País que prospera não faz revoluções". Orçamento equilibrado, moeda forte e fixa, sem câmbios móveis como o ouro, acabam, nessa ótica, com as razões mais fortes de crise.

O brasileiro, exercendo seu papel de ingênuo questionador, aceita as metáforas de Mister Slang (que compara a economia a um navio, ou a condução desse navio) porém não as entende em profundidade. Daí seu parceiro a recriminá-lo: "justamente o balouço excessivo [a instabilidade econômica] é o que impede os reparos, homem!"”. O inglês choca-se com a ignorância do amigo, que não vê as evidências que se lhe estão diante dos olhos.

A dinâmica continua: prosseguindo a conversa, o brasileiro, incrédulo, não acredita que Mister Slang liga ao saneamento das finanças do país sua estabilidade sociopolítica. Ao que o inglês responde com conforto: "Não vou dizer? Digo já, pois toda revolução tem como causa última o mal-estar econômico". As causas podem ser muitas, mas a causa última, a definitiva, é a econômica. Lobato acena com clareza, como Mister Slang: o Brasil está instabilizado por sua economia deficiente, advinda de uma política defasada, atrasada.

Pouco adiante, a conversa é retomada mais explicitamente ainda: 
"- O pobre Brasil tem sido vítima do corre-corre da adaptação a que a instabilidade da moeda o força. Suponha um negociante que fosse obrigado a mudar de casa todos os meses. Que sucederia?

- Todo o seu lucro ir-se-ia nas despesas de mudança e prejuízos conseqüentes. Diz o povo que três mudanças equivalem a um incêndio.

- Pois o pobre Brasil é um negociante que tem de localizar a sua quitando em 27 casas diferentes, conforme as intimações de Mister Câmbio. Como há de o coitado prosperar?

- Realmente. A vida do Brasil tem sido um sair de uma crise para entrar noutra.

- Justo. Chamam vocês crise às mudanças de casa cambial. Crise quer dizer desequilíbrio. Para a volta a um equilíbrio novo há destruição de energias e bens. Como pode enriquecer um coitado destes?" (2008a: 42).

O Brasil é tratado de forma personificada por Mister Slang, que cria uma narrativa em que o país é um negociante a sofrer com as intimações de um estrangeiro (feito ele, ironicamente), Mister Câmbio, que altera o valor do dinheiro, por assim dizer, e prejudica o trabalho do Brasil, impossibilitando a estabilização de sua vida e finanças.

O narrador brasileiro, que só faz concordar, pontua uma conclusão e outra do inglês e viabiliza a conclusão do inglês da Tijuca: não dá para enriquecer com tanta mudança de condição. É o que Mister Slang, precisamente, define como "crise": o desequilíbrio. E não se pode progredir com essa mudança perpétua e sem critério. Daí as crises se sucederem.

Os problemas apontados, contudo, são encarados pelas personagens como chagas a serem curadas, atrasos que precisam ser corrigidos. Não apenas um dedo apontado, conjunto de críticas vãs. O intuito do autor de Mister Slang e o Brasil estipula-se com segurança: demonstrar que os rumos brasileiros, que julga deficientes e atrasados, podem ser ajeitados. Como reconsiderou o Jeca Tatu em Problema vital, Lobato parece dizer: “o Brasil não é assim; está assim”...

Em um dos colóquios temos importante e reveladora exposição de princípios e motivos, quando Mister Slang conversa a respeito da burocracia que verifica em território brasileiro:

“- E que acha deva o governo fazer, Mister Slang? Qual o meio de corrigirse isso?

Mister Slang estava nesse dia de muito bom humor. Assim foi que me respondeu de um modo desnorteante:

— Corrigir para quê? — disse ele. — Se é um elemento do pitoresco local, por que destruí-lo? Todos os povos possuem os seus característicos. Na Alemanha podemos observar a organização levada a extremos inconcebíveis. Nos Estados Unidos vemos a eficiência como a mira de tudo. Modos de ser de cada povo. Se o Brasil prefere o pitoresco, respeitemos-lhe a preferência...

- Esse ponto de vista - exclamei abespinhado - será o de um estrangeiro que não se liga de amor a este país. Um nacional nunca poderá encampá-lo.

- Tem razão o meu caro amigo. Confesso que moro no Brasil apenas levado pelo meu amor ao pitoresco. As coisas brasileiras divertem-me tanto... Não as 
quereria na Inglaterra, está claro. Mas aqui, onde funciono de espectador apenas, confesso não desejar mudanças. Gosto muito de Mark Twain e possuo toda a sua obra. Pois creia que a Central, por exemplo, me diverte mais que The stolen white elephant, a obra-prima, para mim, do terrível humorista americano. Ora, o Brasil não é tão rico em coisas originais para que se dê ao luxo de destruir, reorganizando-a em moldes civilizados, a sua ultrapitoresca estrada de ferro..." (2008a: 81-2).

A discussão aprofundada sobre o estatuto de estrangeiro de Mister Slang se encontra em nosso capítulo 5. Destacamos por ora o que dissemos sobre a Argentina, agora voltado à Alemanha: todo exemplo é válido para aludir a quem procedeu do modo correto.

No entanto, logo após o exemplo "universal", vem o "ideológico", isto é, os Estados Unidos. Fala-se de sua eficiência, um dos fatores sempre lembrados e referenciados por Lobato para alicerçar sua apreciação pelo país americano. Para Mister Slang, a eficiência é uma marca inata do povo americano, uma de suas características constituintes.

A do Brasil, em contraposição, é o pitoresco. Uma espécie de "folclorização" deliberada, que serve ao anedotário, que tem graça e colorido, que é do espírito do país. Mas não se trata de fator positivo. Mister Slang está sendo irônico e pouco deferente para com as instituições brasileiras, que julga ineptas; e seu amigo brasileiro, percebendo a mudança de chave, ressente-se e reclama. É o ponto de vista de um estrangeiro...

Mister Slang leva o sarcasmo a outro patamar e aponta o Brasil como uma sátira (real) mais absurda que os textos humorísticos de Mark Twain (1835-1910), escritor que, assim como Mister Slang, Lobato apreciava sobremaneira, chegando a traduzir posteriormente obras suas ${ }^{43}$. Na segunda metade do livro, a chave para a leitura dessa observação do inglês parece ser a de que há no Brasil certas coisas tão estapafúrdias que a única saída contra o desespero é enxergá-las pelo abundante viés cômico.

Ainda assim, a amargueza de Mister Slang não encontra paliativos quando o assunto é a torpeza e a inabilidade dos governos que vêm e vão no Brasil e não resolvem nada, sequer semeiam a possibilidade de que um dia as coisas sejam diferentes. É com desiludido cansaço que o inglês da Tijuca comentará mais adiante:

\footnotetext{
“- Do que Mister Slang acaba de dizer concluo que com um pouco de boa vontade podemos endireitar a Central.

Mister Slang meneou a cabeça.
}

\footnotetext{
${ }^{43}$ Constam pelo menos as traduções de "As aventuras de Tom Sawyer" e "As aventuras de Huck Finn", sua continuação. A primeira foi realizada em 1934, como informa Fernanda Bondam Soppelsa (2015); a segunda, em 1936, segundo Denise Bottman (2011). Ambas, portanto, poucos anos após a volta de Lobato dos Estados Unidos.
} 
- Absurdo. Nunca o Brasil endireitará essa estrada. Não existe essa intenção em ninguém. Os políticos se beneficiam com esse mau estado. Milhares de parasitas perderiam as tetas se ela entrasse nos gonzos. A regeneração da Central só aproveitaria ao público - única entidade sem a menor voz ativa em coisa nenhuma neste país.

- Mas o fato de a política e os parasitas se beneficiarem com o desmantelo da Central não provará que até no desmantelo há um lado benéfico?

- Para os bacilos que roem os pulmões de um doente, nada mais benéfico que a debilidade geral do organismo desse doente. Sem ela não viveriam eles. Mas que acha o meu amigo de um médico que à cabeceira de um doente vacilasse na cura, em atenção aos bacilos que lhe devoram os pulmões?

- Um absurdo. Médico nenhum vacilaria entre a cura do doente, benéfica a este a toda a comunidade, e a manutenção do estado de doença, só benéfica aos bacilos.

- Pois todos os nossos governos vacilam. Nenhum deles se anima a sanear a Central, em atenção aos bacilos que a vêm entisicando. Os parasitas gozam de "direitos adquiridos".

— Não pode haver aquisição de direitos imorais, nocivos à sociedade humana - adverti.

— No Brasil há. Boa parte do que aqui recebe o nome de direito adquirido é sinônimo de abuso, de lesão do direito natural que tem uma comunidade de se defender contra os parasitas sociais. Eis por que não creio no vosso país. É um país errado. Tem de desaparecer..." (2008a: 88-9).

Nesse duro diálogo, Mister Slang mantém a coerência: faz a mesma comparação com um corpo doente que apontamos páginas atrás. Porém desta feita o humor cede ao desencantamento. O Brasil não funcionará, só as parasitas prosperam e firmam seus direitos, sugando as parcas energias do corpo já debilitado do país.

Os "governos vacilam", o povo é a "única entidade sem voz ativa" para mudar os rumos do país. Mister Slang está cansado. O brasileiro, em vez de disputar com ele e se ofender, também se indigna, usa o mesmo vocábulo para exprimir o que nota errado e o amigo inglês reforça: absurdo.

Agora o que temos não são sugestões para a melhoria do país, nem exemplos de fora. Os (contra-)exemplos são daqui, e não se relacionam a qualquer utopia de aperfeiçoamento. Os governos daqui, os problemas estruturais daqui, os direitos das sanguessugas daqui. Não é de hoje, nem de agora. O corpo doente não resiste a tanta intrusão maléfica. Todos os governos são culpados, nenhuma voz ativa se faz ouvir pelas pessoas; não há ressalvas, completo cenário de desalinho, sem exceções avistáveis ou consideráveis.

O único modo de ver o aspecto positivo da situação é pelo aspecto absurdo, tantas vezes referenciado. O desleixo favorece às parasitas... Todavia, é evidente que esse ponto de vista não pode ser endossado, e tanto Mister Slang quanto seu amigo brasileiro percebem essa contradição que pulsa no corpo doente do Brasil. 
Mister Slang, num revelador desânimo, deixa patente que não acredita nas chances de recuperação do país em que está. "É um país errado... Tem de desaparecer...”.

Presumivelmente para proteger-se de um paradoxo estrutural em Mister Slang se ele despreza tanto o país, que faz aqui? -, Lobato justifica assim sua permanência em território brasileiro:

"Mais tarde vim a saber que Mister Slang se dedicava ao estudo do parasitismo humano e tinha planos de publicar na Inglaterra um tratado a respeito. A razão da sua residência no Brasil prendia-se a tais estudos.

— O campo cá é maravilhoso - disse-me certa vez. — Em parte nenhuma do planeta o parasitismo se aperfeiçoou tanto, nem assumiu tão engenhosas formas. O Brasil pode gabar-se de um recorde...

Entristeci-me (...). Por mais que procure desinteressar-me das nossas coisas, não o consigo, e isso me faz infeliz" (2008a: 92-3).

Para o estudo do parasitismo, Mister Slang elegeu o Brasil como o palco ideal de fenômenos do tipo. Observa-o com lentes empíricas embebidas no humor de observação, visando a publicar na pátria um texto sobre o desmazelo verificado no país latino. Ao brasileiro, resta entristecer-se, por não estar suficientemente distanciado do objeto em questão ${ }^{44}$.

O inglês, ao se despedir no final dos colóquios, pontua:

“_É que parto amanhã para Hong Kong e vim despedir-me da cidade — foi sua resposta.

Assombrei-me. Aquele homem partia para a China como nós partíamos ali para a Vista Chinesa, sem aviso prévio, sem atroar os ouvidos do mundo com o brasileiríssimo grito de guerra: 'Vou para a Europa, sabe?'. Viajar para Mister Slang era coisa tão comezinha como tomar um café expresso...

— E qual o motivo, Mister Slang, da sua fuga, se não é indiscrição?

- Cansaço do Brasil.

- Detesta assim o nosso país?

- Ao contrário, adoro-o, e para meu estudo sobre o parasitismo não creio que haja no mundo campo melhor..

- Sempre a cobaia...

- Mas como tudo cansa, costumo periodicamente descansar do Brasil. O ano passado descansei do Brasil na Suécia e cansei-me logo da Suécia. A ordem que lá reina é excessiva, meu caro. Mata o pitoresco. Ao cabo de três semanas voltei, saudoso deste maravilhoso Éden dos imprevistos" (2008a: 125).

Pêndulo entre o anseio pela correção e o gosto pelo absurdo, Mister Slang faz de suas viagens uma inconstante busca de extremos. Da ordem à desordem, e vice-versa. Chama o Brasil de "Éden dos imprevistos", onde não há a ordem "excessiva" que verificou na Suécia. Cansa-lhe o perfeito funcionamento das coisas e a total bagunça instituída.

\footnotetext{
${ }^{44}$ A questão do distanciamento de que Mister Slang se vale para "falar o Brasil" será esmiuçada no último capítulo do trabalho.
} 
O próprio Lobato fez as vezes de Mister Slang em muitos momentos posteriores, inflamado em suas críticas contra as estruturas políticas e econômicas do país. O escritor disse em 1941 que "o governo no Brasil não passa de pura emanação da burocracia. Os homens do governo, presidentes, ministros, legisladores, têm e dão ao povo a impressão de governar, mas quem na realidade governa é a burocracia" (2009c: 81).

Resta difícil separar as conclusões de Mister Slang das de Monteiro Lobato. Para Edgard Cavalheiro, Lobato "se divertia impingindo como alheias as observações do inglês" (1955: 342). Ambos pregam a refundação do país que "deu errado" e estrebucha, comido pelos vermes da ineficiência e da burocracia paralisante.

\subsection{LOBATO TURISTA AMERICANO OU MISTER SLANG ABROAD: AMÉRICA}

\subsubsection{MISTER SLANG PARA O RESGATE}

O outro livro em que Mister Slang aparece, América, é o termo final da nossa circunscrição lobatiana adulta. Publicado em 1932, um ano após a volta de Lobato para São Paulo, e constando nos planos de suas obras completas como "impressões de viagem", América é de algum modo um apanhado de novos colóquios entre Mister Slang e o brasileiro, novamente narrador, que se reencontram anos depois das conversas descritas em Mister Slang e o Brasil.

Se Mister Slang e o Brasil era um "ideal americano" de Lobato, América é o Lobato que já viajou aos Estados Unidos, conheceu algumas de suas instituições e organizações, provou das glórias e fracassos do American establishment - perdendo dinheiro no famoso crack da Bolsa de Nova Iorque, por exemplo; Cavalheiro indica que, “sempre superlativo nos entusiasmos, a corrida à riqueza rápida o atrai como poderoso ímã. Também especula na Bôlsa com os parcos recursos de que dispõe. Quando em outubro de 1929 sobrevém a crise fatal, tudo quanto possui rola nas águas do craque" (1955: 368) - e continua fascinado por seus mitos fundacionais e o mítico espírito empreendedor estadunidense. Com uma diferença capital: agora já pode se portar de modo mais crítico e ponderar algumas questões: o coloquialismo vocabular, a confusão ideológica em tempos pré-Guerra Fria, a censura na arte (mais especificamente no cinema), entre outros tópicos.

Observemos como a experimentação pessoal muda ou adensa o discurso do autor. É o narrador quem diz: 


\begin{abstract}
"Washington é um símbolo de pedra. A historia americana está toda ali. Basta uma visita á cidade para que os fatos capitais da formação politica da America se desenhem para sempre em nosso espírito. Daí a forte reamericanização que sofrem os americanos de visita á capital. Saem de Washington mais americanos, mais exaltados na tremenda fé em si proprios que acima de tudo os caracteriza. Povo eleito para os mais altos destinos, Washington é o crisol mistico onde se sublima essa fé cega. From Washington we go home better americans" (1951a: 32).
\end{abstract}

América mostra-se, portanto, um livro menos "direto ao ponto" que o anterior. No sentido de que busca não só criticar nossos costumes mas comentar visões, projetos, idiossincrasias permeadas por um saber vivenciado pelo escritor. Há mais capítulos, a obra é mais encorpada, Lobato se detém descrevendo em minúcias ambientes, fatos e anedotas americanas.

Cumpre observar que o discurso de uma obra que nasce pronta como livro também tem efeitos diferentes do que se verifica num jornal, com todas as questões logísticas, de abordagem e editoriais concernentes. A liberdade formal se manifesta em certas decisões: há capítulos sem colóquios, uma mudança radical comparada à forma rígida do livro anterior $^{45}$. Nesses capítulos a dinâmica se faz diferente, com extensa descrição de ambientes e fatos, como o verdadeiro diário de um turista, e também comportam elucubrações "a sós" do brasileiro, que reflete sobre o que vê e sente.

No prefácio da obra, o narrador conta, à guisa de mal disfarçado "gancho" com o livro anterior, as impressões que Mister Slang lhe deixou e o que disso adveio:

\begin{abstract}
“As ideias de Mr. Slang sabiam á minha simplicidade d'alma como a propria quintessencia dos fatos destilada em alambique de alta precisão. Durante o periodo em que com ele convivi gosei de intensa euforia, a ponto de julgar-me genio em trabalhos de desabrochamento. Tinha o inglês da Tijuca o poder de fecundar em mim germens de ideias, ou transmitir-mas em jacásinhos, já de raiz - e assim me transformou por uns tempos num lindo jardim de coisas raras, senão novas.

(...)

Impingi aos amigos as ideias de Mr. Slang como se minhas fossem, muito me regalando com o espanto deles.

Com o seu afastamento sofri enorme decepção. (...) Compreendi, então, que na minha simbiose mental com o inglês meu papel fôra apenas de parasita - que tudo tira e nada dá em troco.

Nunca mais vi, nem tive noticias de Mr. Slang, isso durante anos. Um belo dia, porém, em Washington...” (1951a: 8-9).
\end{abstract}

Mister Slang funcionou no livro anterior, agora o narrador o confessa (como se não fosse evidente), como um mentor para o brasileiro, a pessoa que lhe abriu os olhos e expandiu os conceitos - que, numa chave reveladora, adota para si. Essa confusão entre

\footnotetext{
${ }^{45}$ Para precisar, registramos que se trata dos capítulos XV, XXI e XXIII, além do prefácio.
} 
o narrador e Mister Slang, e de certo modo entre eles e Lobato, é uma das técnicas do escritor para fazer valer suas ideias. Mais adiante analisaremos o que essa operação de avatares alcança na estrutura da obra e ambiciona em termos de retórica textual e tentativa de convencimento dos leitores.

Em relação às semelhanças com Mister Slang e o Brasil (o que pode ter levado Lobato a querer continuar a "saga" das duas personagens), o britânico Mister Slang continua um discreto apologista dos avanços ianques, e o narrador brasileiro continua envergonhadíssimo das deficiências brasileiras para com os Estados Unidos. É como se os anos que passaram separados não fizessem sentido: Mister Slang existe para explicar o atraso do Brasil, o brasileiro existe para reconhecer o avanço do resto do mundo.

Por isso o prefácio, no qual o narrador declara tacitamente sua necessidade de tutoria intelectual por parte do inglês, reconhecendo-se deficitário espiritualmente desde que se perderam de vista. As razões são de feições diversas. O narrador chega a apontar que sua vida pessoal se ressente da ausência de Mister Slang; sem o colorido de suas opiniões, o brasileiro, despido da verve comunicativa e a fineza de investigação de seu colega, não consegue manter por muito tempo como suas as opiniões alheias, e tristemente afirma que "os amigos desertaram-me. Com grande desapontamento, passei a simples pedaço do bicho Toda-Gente - peludo, sorno, sovado, carne-de-vaca" (1951a: 9). O prefácio grita a urgência do retorno de Mister Slang, em benefício do desacorçoado rapaz.

A estrutura de América, no entanto, em certo sentido revela-se antitética à de Mister Slang e o Brasil: se nos primeiros colóquios a questão resolvia-se sobretudo verbalmente, em América os passeios pelas localidades dos Estados Unidos trazem novas dimensões, perspectivas e facetas às discussões sobre as especificidades americanas e o respectivo contraponto à realidade brasileira. Como se agora confirmassem "na prática", vendo para crer.

A pesquisadora Vanessa de Paula Hey aponta que, "em América, esses passeios instrutivos são uma das formas pelas quais o narrador entra em contato com esse novo mundo, onde descobre lugares diferentes dos já visitados por ele antes e também vivencia todo o progresso dessa grande nação" (2018). Um desdobramento prático de uma dimensionalidade antes descrita teoricamente.

Não se pode chamar de exígua a contribuição do novo foco ótico, por assim dizer; com exemplos concretos, toda a argumentação parece se fortalecer, bem como pode interessar e atrair pelo pitoresco, a descrição dos prédios e situações cotidianas, os casos 
muito comentados - como o julgamento do comediante cinematográfico Roscoe 'Fatty' Arbuckle ${ }^{46}$.

Sob esse ângulo, América diferencia-se de Mister Slang e o Brasil por ser bastante mais documentado, com números, estatísticas e notícias recentes, usados pelo inglês da Tijuca em suas argumentações como fator relevante para provar suas alegações. Milena Ribeiro Martins conclui que

\begin{abstract}
"Mais do que um passeio pelos Estados Unidos, América funciona como um convite à leitura daquele país, por meio do contato com textos e ideias que lá circulavam. Não por acaso, seu autor era um editor e um tradutor: ele selecionou, traduziu e pôs em circulação, no seu país, textos e ideias do país visitado" (2017: 27).
\end{abstract}

\title{
3.2.2. O BRASIL NOS ESTADOS UNIDOS
}

Lobato não perde o Brasil de vista, mesmo num livro que é, desde o título, sobre os Estados Unidos. Seja porque uma de suas intenções é "abrir os olhos" dos brasileiros, que consumiriam seu América, seja porque, afinal, o Brasil é, aos olhos do escritor, um contraponto perfeito em algumas situações - quando denuncia a ineficiência de nossas instituições e governados.

Ao comentar a marcha inexorável do progresso, Mister Slang afirma que "a America impõe rapidez de julgamento e trote largo. Quem fôr lerdo de cabeça ou de movimentos, que emigre, para não ser esmagado. Paises onde ninguem corre não faltam" (1951a: 72); logo depois, no capítulo seguinte, traz o Brasil como contraexemplo:

\footnotetext{
"Veja no seu país [falando ao amigo brasileiro] que desastre está sendo a interferencia oficial no negocio do café. Houve um desequilibrio entre a produção e o consumo. Em vez de deixarem que o natural reajuste se fizesse, surgiu a intervenção do Convenio de Taubaté - semente da maior calamidade que vai desabar sobre o Brasil"' (1951a: 73-4).
}

O narrador brasileiro questiona essa visão e, apresentando imediatamente seu ceticismo, força o parceiro inglês a entrar em detalhes: então Mister Slang usará números, dados e até informações de que dispõe tirando "da valise um livro de estatisticas comerciais onde se via um grafico das exportações do Brasil” (1951a: 74). A solução é eminentemente artificial, mas crível no espírito da obra: Mister Slang não fica sem argumentos, e não está errado virtualmente nunca. Para tanto, tem-se bem informado, com material de documentação confiável, sempre renovado e atualizado - outra marca de

\footnotetext{
${ }^{46}$ Referenciado por Lobato pelo nome com que ficou conhecido no Brasil, Chico Boia.
} 
ironia ao contrapô-lo com o amigo brasileiro, que em nada se informa acerca de seu país. É como se fosse dito: Mister Slang não dá palpites, apresenta fatos.

A artificialidade de uma construção como a referida contribui para o caráter "programático" das opiniões de Mister Slang. Não são apenas intromissões ou mexericos, mas legítimos postulados; o inglês sabe o que é melhor para o nosso país, e estando nos Estados Unidos mostra in loco como se comporta uma nação que fez corretamente tudo que fazíamos errado. Não há espaço para dúvidas, havendo: a) provas das mazelas brasileiras; b) fatos documentados; c) exemplos vindos de uma nação que corrigiu o que no Brasil não se corrige (por ineficiência, falta de visão, condescendência criminosa etc.).

Tal artificialidade, contudo, pode resvalar para o que hoje, com nosso moderno corpo de informações e nosso espírito crítico aguçado pela profusão de fontes de checagem, teríamos por ingenuidade. Temos correntemente a fundamentada desconfiança, aparentemente inexistente em Lobato, que não é necessariamente importando técnicas e exemplos de outros países que o progresso chegará do mesmo modo em nossas terras. Caio Prado Junior, em seu prefácio para $O$ escândalo do petróleo, avalia "a situação de paises como o Brasil, que em vez de elaborarem uma cultura propria na base de suas condições, experiencia e necessidades particulares, contentam-se em aceitar passivamente modelos criados em circunstancias estranhas e diferentes das suas" 47 (1951b: XV).

O escritor explica em diversas ocasiões, não obstante, por que acredita que os métodos empregados nos Estados Unidos, o exemplo maior e mais crucial para nossos propósitos, seriam adequados para o Brasil:

\footnotetext{
"Sempre nos impressionou fundamente o fato de dois paises de igual territorio, Estados Unidos e Brasil, situados no mesmo continente, descobertos ao mesmo tempo, colonizados com os mesmos elementos humanos, libertados do jugo da metropole com pequena diferença de anos, alcançarem, um, o fastígio da grandeza e a situação de primeiro entre todos os povos da terra, e o outro, nós, a triste posição de beco sem saida em materia de encalacramento.

Instituições politicas? São as mesmas. Raças? São as mesmas - branca e negra. Clima? Temos metade do país, pelo menos, maravilhosamente adequado á prosperidade do homem. Por que, então, tão disparidade do destino?" (1951c: 258-9).
}

\footnotetext{
${ }^{47}$ Talvez o exemplo mais patente de como nossas diferenças estruturais não são tão facilmente contornáveis pela adoção de medidas "estrangeiras" esteja em Raízes do Brasil, o livro mais conhecido do fundador do IEB Sergio Buarque de Hollanda (2015). O autor analisa em muitos capítulos a formação de nossas culturas advindas dos diferentes modelos de colonização europeia em terras americanas diversas, tais como os casos de Portugal e Brasil, Espanha e América Latina, Inglaterra e Estados Unidos etc. Em linhas gerais, podemos apontar que fatores outrora insuspeitos como configuração climática, topologia e tradição cultural podem estabelecer diferentes quadros de trabalho e desenvolvimento social. Como se simplesmente alguns procedimentos "amoldassem-se" a alguns territórios, por essas e outras razões contextuais, e outros simplesmente não o fizessem.
} 
Lobato perscruta entre as linhas gerais das organizações civis e sociais das comunidades americana e brasileira - como a hierarquia política via representação de eleitos e os grupos étnicos a seu ver parecidos -, argumentando que temos todas as condições que os americanos tiveram para prosperar, só não soubemos (ou sabemos) aproveitá-las.

A crença em valores absolutos ou no simples transporte de ideias de um país a outro redunda por vezes, contudo, em um fascínio pueril por figuras simbólicas, hiperbolizadas ou superlativas. Sobretudo entes políticos ou empresários como Henry Ford e William H. Smith, o desenvolvedor de um método para produção de ferro que o escritor paulista aclamaria e tentaria patrocinar no Brasil.

Como discutimos neste trabalho, figuras como Lincoln são usadas por Lobato num registro quase mitológico, inumano, para reforçar valores caros ao escritor. No entanto, o adensamento da complexidade desses homens públicos se perde, ao menos em parte, no processo de sua transformação em ícones de moralidade. Podemos vislumbrar, nas palavras do narrador de América, uma amostra dessa prática:

\footnotetext{
"Paramos na grande cidade para ver o que havia ali de Brasil. Artes de D. Pedro II. Tinha o grande monarca a mania de interessar-se pela sua terra - daí o banirem-no, como castigo.

(...)

Pedro II lá esteve e até hoje os americanos guardam lembrança dessa sensacional visita - o primeiro e unico imperador que ainda pisou as plagas de Lincoln. Descobriu ele por essa ocasião o criador do telefone, Graham Bell e o lançou... A America jamais se esqueceu disso" (1951a: 75-6).
}

Ao fazer o panegírico do segundo monarca do império brasileiro, Lobato confirma, paradoxalmente, sua independência de pensamento: não havendo registro específico e seguro de uma sua admiração por monarquias, ressalta em Pedro II a honestidade de caráter, a disposição intelectual e outros valores morais que entendia serem interessantes em um governante - e absente na maioria deles. Para deixar clara sua admiração pela figura de Pedro II, Lobato aproxima-o de algum modo a Lincoln, vulto histórico citado em muitos de seus livros e sempre de modo paradigmático.

Interessa aqui observar como se dá o discurso do narrador. Descortinando ao leitor certos sítios turísticos, o brasileiro trata os passos biográficos de Pedro II como apriorísticos, dando como "favas contadas" os deveras discutíveis elementos que escolhe para definir, em poucas linhas, a trajetória do imperador em seu relacionamento com a América. "Tinha o grande monarca a mania de interessar-se pela sua terra" é aqui um pressuposto do que causou a deposição e consequente banimento do imperador. 
Logo de princípio, todavia, poder-se-ia argumentar que a correlação família imperial-Brasil é problemática, uma vez que se trata de uma estirpe europeia no poder, ainda que independente politicamente da ex-metrópole, à qual permanecia ligada por laços de sangue.

Os registros apontam que Pedro II era realmente querido por suas qualidades humanas, ou sua alegada disposição virtuosa. Luís Martins afirma no ensaio $O$ patriarca e o bacharel que "todas as pessoas que deixaram depoimentos pessoais sobre o imperador estão acordes na referência à sua bonomia meio sabichona, à vigilância um tanto estreita que ele próprio exercia pessoalmente (...) sobre a moral de seu povo" (2008: 109).

Esse verdadeiro culto à personalidade teve reflexos na conturbada proclamação da República em $1889^{48}$. Apesar de a forma de governo ter sido alterada, os valores humanos do monarca deposto encontravam apoiadores até entre os novos republicanos, que, por impropriedade da nova conformação política, viam-se agora sem um modelo humanístico como o era considerado Pedro II. Luís Martins assevera que "uma vez alcançados seus fins, a rebeldia liberal começou a se amortecer sentimentalmente num verdadeiro complexo de remorso" (2008: 110).

Lobato, que passou a infância tanto sob a monarquia quanto sob os primeiros anos da hoje chamada República Velha, tinha em seu cerne essa contradição: admirava a figura do imperador, mas não compactuava com o sistema monarquista. Ainda assim, lamenta a saída "intempestiva" de Pedro II, considerando-o digno até o fim - muito diferentemente de um Graciliano Ramos, que descreveria em tintas acres o exílio forçado do monarca, em sua Pequena História da República: "Na noite de 17 desceu as escadas do palácio bastante contrariado, resmungando para o tenente-coronel Mallet, que o ia buscar.

- Estão todos malucos. Não embarco, não embarco a esta hora, como negro fugido" (2000: 146).

Associado o monarca à quintessência do progresso, numa terra onde o progresso se faz dificultoso e truculento (quando não inexistente), o narrador de América relembra o encontro entre Pedro II e Alexander Graham Bell, o inventor do telefone. Ficaria do monarca deposto seu exemplo de dignidade humana, sua decência moral e intelectual, seu gosto por novidades que o torna afim dos americanos, povo tido como inclinado ao aperfeiçoamento material da sociedade e invenções e utilidades em geral.

\footnotetext{
${ }^{48}$ Conturbada pelas condições de todos sabida: proclamada por um militar monarquista amigo pessoal de D. Pedro II e que logo tentaria dar um golpe no Congresso, falhando e renunciando ao governo.
} 


\subsubsection{A AMÉRICA CRITICADA OU UMA CHECAGEM EMPÍRICA DOS ESTADOS UNIDOS}

Como referido, o narrador demonstra em América alguma desilusão com os Estados Unidos, uma nota ácida possível a Lobato apenas neste momento de sua trajetória humano-literária, quando ele efetivamente foi ao país ianque e deparou com suas glórias e suas contradições. Lobato, apologista dos métodos americanos, não deixa de ser um brasileiro; e, como o brasileiro a quem dá voz como narrador, é cheio de dúvidas sobre os caminhos que os americanos trilharam para chegarem aonde estão.

América representa nesse sentido uma "checagem" dos Estados Unidos, uma tentativa de o escritor comprovar (e descrever) o que tanto lhe entusiasmava na nação americana. Continua animado com os processos e resultados encontrados, majoritariamente; porém, critica ou ironiza aquilo de que se distancia, não concorda ou não entende. Logo no segundo capítulo do livro, ao ouvir de Mister Slang feitos heroicos de cachorros e as recompensas (heranças, prêmios em dinheiro, artigos elogiosos em jornais e afins) que os animais recebiam por suas condutas elogiosas, o brasileiro externa sua perplexidade:

“- Isso me parece maluquice, Mr. Slang, comentei eu, sorrindo, com a superioridade de quem já havia dado muito pontapé em cachorro.

(...)

Dei uma gargalhada, isto é, comecei a dar uma gargalhada á moda indigena. $\mathrm{Vi}$, porém, que estava numa terra onde receber um fato desses com uma gargalhada podia até ser caso de deportação por "atividades comunistas", e recolhi-a a tempo. Mr. Slang compreendeu a minha manobra.

- Sim, meu amigo. Se quiser viver feliz na America, não se mostre duro com os cães - nem desrespeitoso para com a americana. São dois dogmas muito sérios" (1951a: 22-3).

Mister Slang mostra ao brasileiro recortes extraídos de periódicos, o que de algum modo atesta a veracidade das histórias. Milena Ribeiro Martins compilou as notícias que Lobato consultara em sua estada em terras americanas e cotejou-a com o texto publicado $^{49}$. O resultado foi que Lobato praticamente parafraseou notícias inteiras, o que apresenta conotações interessantes para análise.

Entendemos que, munido de tal documentação, o escritor em certa medida protege-se de críticas que poderiam ser feitas a seus "livros americanos" anteriores: pressuposições questionáveis, conclusões precipitadas, empolgações desmesuradas.

\footnotetext{
${ }^{49}$ Os resultados encontram-se no capítulo que Milena publicou em Monteiro Lobato, livro a livro: obra adulta (2014).
} 
Aqui, são os americanos falando de si, não um brasileiro louvando ou criticando de acordo com seus códigos pessoais.

Não obstante, é um procedimento complexo, pois carrega em si o germe do próprio paradoxo textual: utilizando diretamente as notícias dos americanos, o narrador assume para si o encargo de fazer o contraponto, que necessariamente adotará, ainda que moderadamente, um tom crítico. Assim, no excerto transcrito, o narrador brasileiro considera risível a "adoração" que os americanos fazem de animais prosaicos como cachorros. Sente-se acima dos outros, gargalha. Para ele, é absurda a "louvação canina" verificada em terras americanas. Notemos que, nesse ponto, ele não procura adequar-se aos costumes de fora, mantendo-se convicto de sua superioridade.

O narrador justifica a contenção de sua risada afirmando, num registro irônico, que "estava numa terra onde receber um fato desses com uma gargalhada podia até ser caso de deportação por 'atividades comunistas"'. Lobato registra aqui que já nos anos 1930 o sentimento anticomunista era intenso nos Estados Unidos, uma visão que hoje temos assaz diferente por causa da força que o conceito de macarthismo adquiriria no inconsciente coletivo mundial - vale lembrar que esse período associado à "caça às bruxas", em que havia uma quase paranoia na polarização política representada pelos valores contrapostos de "americanismo" e "comunismo", verificou-se décadas depois, entre 1947 e 1956.

Lobato seria acusado em alguns momentos de sua vida de ser comunista, conforme verificado em nossas pesquisas ${ }^{50}$. Indagado sobre se seria socialista, o próprio escritor declarou em entrevista a Tulman Neto, do Diário de S. Paulo, em 1945: "Não sou coisa nenhuma além dum observador da história. Olho, vejo e digo o que vejo - só, mais nada. Para que ser alguma coisa?" (2009c: 138).

Sem embargo, consideramos que o comentário do narrador brasileiro aqui possui outra chave de leitura, algo assemelhada à do elogio feito a Pedro II: não se trata de uma carta de declaração de princípios ou filiação partidária, mas uma defesa de algo maior; no caso de Pedro II, das virtudes morais e intelectuais de um bom governante, e aqui, da liberdade de pensamento e da possibilidade de expressar sem censura opiniões e comentários.

\footnotetext{
${ }^{50}$ Ver no Anexo 3, por exemplo, a comunicação de Lobato ao Diário de S. Paulo em 6 de fevereiro de 1948 - menos de um semestre antes de sua morte - ou a carta recebida por Lobato do correspondente Rinaldo de Biasi, escrita em 26 de agosto de 1945.
} 
Notemos ainda que é o próprio Mister Slang quem diz ao brasileiro que há na América certos “dogmas”. A palavra é dura, e pode-se dizer que tem um sentido próprio na bibliografia lobatiana, ao menos se pensarmos que o escritor praticamente sempre se manteve afastado da Igreja e das religiões, sendo constantemente "acusado" de ateu ou crítico imoderado das instituições religiosas - em algumas cidades (inclusive a terra natal do autor, Taubaté, ou a então capital federal Rio de Janeiro), há recordação de autos de fé com a queima de seus livros promovidos por entidades religiosas ${ }^{51}$. Edgard Cavalheiro reporta um deles: "No externato do Sacré Coeur de Jesus (...), piedosa Freira solicita de todas as alunas que possuam livros do criador de Narizinho, que os levassem ao Colégio (...). Reunidos os volumes, depõe Raul de Lima, a Revma. Irmã e educadora fêz uma fogueira (...) e queimou-os todos" (1955: 594). É um ponto curioso da recepção da obra de Lobato, mas que não é escopo deste trabalho examinar.

Importa, contudo, relacionar a defesa das liberdades com os “dogmas" que Lobato encontrou em sua viagem aos Estados Unidos. O país cujo lema ou epíteto ('a terra da liberdade') mais parece um slogan - demonstrando a força da publicidade na terra americana - tinha naqueles anos preocupações de política externa de tal monta que a um estrangeiro como Lobato pareciam exageradas, problemáticas ou simplesmente dogmáticas.

Queremos dizer que assim como Lobato não defendia necessariamente a monarquia ao fazer o panegírico de Pedro II, igualmente não está aqui defendendo o comunismo ou qualquer outro sistema, exceto as liberdades humanas de expressão e opinião, que lhe eram tão $\operatorname{caras}^{52}$.

Outra crítica que Lobato faz via suas personagens passeando nos Estados Unidos refere-se a questões linguísticas. Mister Slang, inglês, ressente-se das modificações que encontra no inglês americano:

“- Ainda não pude suportar esta liberdade dos americanos para com a lingua inglesa, disse-me ele de caminho. Corrompem-na barbaramente.

- Corromper, Mr. Slang, não será um sinonimo colerico de evoluir?

- Talvez, mas não é coisa que meus nervos suportem. Já cacei tigres na India e leões no Uganda. Não mexem com os meus nervos. O Ain't mexe.

\footnotetext{
${ }^{51}$ Vindo ao encontro dessa visão que une dogmas religiosos a uma proclamada ojeriza pelo comunismo, $\mathrm{o}$ padre Sales Brasil publica em 1957 a obra "A literatura infantil de Monteiro Lobato ou o comunismo para crianças", pelas Edições Paulinas.

${ }^{52}$ Mais adiante, em América, Lobato condenará a censura moral perpetrada nas obras cinematográficas, lamentando, ao comentar as mudanças sofridas pela adaptação da peça teatral Coquette, que "tais alterações destruiam toda a força, unidade e originalidade do tema" (1951a: 131).
} 
- Mas é esse o meio duma lingua desenvolver-se! Não fosse a audacia inconciente dos ignorantes, e estariamos ainda hoje, aqui no Novo Mundo, a falar o inglês ciceronico do Dr. Johnson.

—E que lindo seria!...” (1951a: 58).

Consideramos que aqui o eco das aventuras pessoais de Monteiro Lobato faz-se evidente. Mesmo conhecendo inglês a ponto de ser destacado tradutor do idioma, como já o referenciamos, Lobato, em viagem aos Estados Unidos, complicou-se com as exigências fonéticas do falar americano. Relata em carta a Godofredo Rangel datada de 5 de setembro de 1927:

\begin{abstract}
“O americano troca o ' $\mathrm{t}$ ' por ' $\mathrm{r}$ ', de modo que até um inglês de Londres se atrapalha em Nova York. Há dias pedi water num restaurante. O "waiter" isso aí que vocês chamam garçom - olhou-me com cara d'asno. Repeti. A glass of water, please! Ele ainda ficou no ar uns instantes. Depois seu rosto iluminou-se (era um garçom inteligentíssimo) e disse: "Warer?" e trouxe a água pedida. Tomato é "tomeiro" - e eu sou "Mister Lobeiro". Filha é "dórar" e What of it? é "Oróvet". Fui comprar uma fita de máquina. "Standard ou Pôrabal?", perguntou o homem. Espertissimamente adivinhei que "pôrabal" queria dizer portable - máquina portátil” (2010a: 524).
\end{abstract}

A transposição de um tal episódio não poderia ser mais clara, inclusive com uma menção à atrapalhação de "um inglês de Londres"! Em América, sob a roupagem ficcional dos colóquios americanos entre o inglês e o brasileiro, o sentido da crítica linguística se faz pelo comentário, no mais laudatório, referente à velocidade das coisas nos Estados Unidos. Tudo muda muito rapidamente, os americanos fazem seu progresso avançar a olhos vistos, não há tempo para a inércia (gramatical, inclusive) que se verifica no Brasil e em tantas outras terras:

“_ Culpa têm os ingleses que fizeram da sua lingua uma lingua livre cambista. A entrada de palavras na lingua inglesa é franca. As palavras chegam de toda parte e estabelecem domicilio no inglês sem que a policia glotica as marque com qualquer sinal indicativo de que são de fóra. Gosto disso, porque sou duma terra terrivelmente protecionista em materia de lingua. Palavra exótica que entra no Brasil tem de ficar anos e anos marcada com grifo, ou entalada entre aspas, antes que seja naturalizada.

(...)

Talvez o mal de que nós ingleses nos ressentimos venha da rapidez com que a evolução da lingua se opera aqui. Inda não nos pudemos conformar com a mania da America de fazer num ano o que sempre pediu vinte. Isso não dá tempo ás celulas cerebrais de se adaptarem - e esquecerem” (1951a: 59).

Ainda assim, Mister Slang vale-se dos "seculos de filosofia anglo-saxônica" (1951a: 13) acumulados em si para, insuspeitadamente, comparar Brasil e Estados Unidos no que vê e observa. Age como uma terceira parte, ontologicamente neutra, que nada ganha elogiando ou favorecendo esta parte ou aquela. 
O interesse de Mister Slang, como dissemos, é apresentar fatos: aos ouvintes, o narrador brasileiro ou seus desconhecidos leitores, cabem as conclusões - dificilmente diversas do que Mister Slang conclui, pela força de seus argumentos e a expressividade de sua retórica.

Esse procedimento cria um ponto de sagacidade na obra e decifra parte do pensamento lobatiano, pois quando Mister Slang afirma categoricamente um fato, provao e convence o narrador brasileiro, que não mais apresenta dúvidas ou questionamentos. Fica então um ponto que Monteiro Lobato fixa e determina, podemos assim dizer, como indubitável. Como disse Emília no começo de suas Memórias, "verdade pura, da dura" (2017b: 11). Quem duvidar de Mister Slang nessas assertivas está desde já derrotado: o inglês, sem interesse pessoal na questão, apresenta os fatos, "inquestionabilizados" pela retórica tripla da personagem (Mister Slang), seu narrador (o brasileiro anônimo) e seu autor (Lobato) ${ }^{53}$.

Por vezes, a comparação é tão intensa que o inquieto narrador brasileiro, fonte inesgotável de contrapontos, sequer apresenta objeção. É o que acontece quando Mister Slang detém-se em capital problema para Lobato: a questão da mecanização.

Assunto controverso na literatura sócio-política - Eric Hobsbawm, a respeito das novas condições advindas na sociedade inglesa com a revolução industrial, aponta que, no meio do século XIX, muitos tecelões manuais "tornavam-se cada vez mais famintos e, numa tentativa vã de competir com as novas máquinas, trabalhavam cada vez mais barato" (2011: 84) -, a relação do homem com a máquina era tema de apaixonadas reflexões do escritor. Lobato posicionava-se inequivocamente a favor da gradual mecanização das forças brutas de trabalho, defendendo o aproveitamento humano em outras atividades e consagrando o grosso do trabalho braçal a máquinas. Vejamos essa defesa advogada por Mister Slang:

"- Muitas vezes no Brasil ouvi da boca de seus patricios que Deus é brasileiro, disse Mr. Slang, como se estivesse adivinhando meus pensamentos. Ao americano jamais ocorreu inventar coisa parecida; no entanto, a verdade me parece ser Deus escandalosamente americano - se não de nascimento, pelo menos naturalizado. Não existe territorio no mundo mais rico que este - e esta é a razão do surto prodigioso da America. As mais extensas e ferteis planicies de cultura, tão bem ajeitadas para o trabalho mecanico que o serviço não mais necessita ser feito a unha humana ou casco de boi, como é classico em materia de agricultura. Tudo a maquina. Daí uma agricultura sempre em crise por excesso de produção. Trigo demais, algodão demais, batatas demais, frutas demais. A eterna crise agricola, entretanto, não evita que os lavradores

\footnotetext{
53 "A voz do estrangeiro", poderoso fator de convencimento no contexto da obra americana de Lobato, será discutida mais detalhadamente em nosso capítulo final.
} 
mantenham o padrão de vida que você está vendo. Lá vai aquele freguês de charuto na boca, conduzindo o seu trator. Ganhara quanto? Cinco, seis dolares por dia. Não está contente, é claro. Como não o estará quando seu salario subir a dez ou vinte. É da natureza humana, e condição do progresso, a dessatisfação do presente, com ansia de mais para o futuro. Compare, porém, a vida desse homem com as dos seus irmãos nos outros paises...

(...)

- Onde o classico ilota agricola, continuou Mr. Slang depois de breve pausa, o homem dobrado nos cabos do arado, em tudo acorde á famosa pintura de La Bruyére? O trabalho bruto foi transferido para a maquina. Ao homem ficou dirigir a maquina. (...)

- Não é preciso ir tão longe como essa França de La Bruyère, acrescentei suspirando com alma. Em todo o mundo, em todo o resto da America, no Brasil - que é o homem do campo? Já fui fazendeiro, sei. O 'camarada' ocupa o ultimo degrau da escala social. (...)

Aquele patife lá, de charuto na boca e perneiras, com radio em casa e certamente um Ford no fundo do quintal, ganhará quanto? No minimo cinco dolares por oito horas de trabalho. O nosso Jéca, por um trabalho muito mais penoso e de sol a sol, apanha, em media, 2.000 réis, que ao cambio de $10 \$ 000$ por dolar correspondem a 20 centavos - a vigesima quinta parte do jéca americano!" (1951a: 64-7).

Essa longa conversa entre Mister Slang e seu interlocutor brasileiro, em que não faltam detalhes controversos, ácidos e incisivos sobre os hábitos do homem do campo brasileiro, seu vestuário, suas condições higiênicas e que também versa sobre o estado de aproveitamento virtualmente integral dos campos agrícolas americanos, é reveladora em uma profusão de sentidos.

A influência francesa, que discutimos no primeiro capítulo, faz-se presente pela referência a Jean de la Bruyère, moralista francês do século XVII (1645-96). Lobato como que se esconde na referência, demonstrando que o que ele vê e critica não é novidade, não é de hoje. As coisas não mudam ou mudam muito lentamente, sem ação de algum fator externo ou catalisador. No caso, a máquina, que vem a mudar o que é um atraso, ou seja, a agricultura ser feita "a unha humana ou casco de boi”. Mister Slang, mais uma vez, fala por seu autor.

Lobato resolve deixar o jogo de avatares ainda mais explícito. $\mathrm{O}$ narrador brasileiro fala, de supetão: “já fui fazendeiro, sei”. Essa informação, não dada em outro momento, tem uma importância que se relaciona com a própria diegese da obra: afinal, qual dos brasileiros fala, o narrador anônimo ou o autor (Lobato)? Parecem confundir-se na inesperada e passageira informação. O empirismo, um dos pilares de América, desvelase em outra chave, também ligada à biografia do escritor: Lobato, que já foi fazendeiro, sabe.

Esse elemento empírico é sobremaneira relevante, com uma estrutura verdadeiramente multifacetada. Monteiro Lobato ou suas ideias podem ser encontrados 
em qualquer uma das duas personagens recorrentes no livro, e dá suas credenciais de autoridade: Mister Slang, informado e erudito, fala a América; o brasileiro, que "já foi fazendeiro e sabe", fala o Brasil. Ainda assim, pela própria construção textual algo atabalhoada, os backgrounds das personagens se misturam de maneira pouco clara, como se ambos pudessem falar as mesmas coisas, pelo menos nas ocasiões quando estão de acordo.

Uma ilustração dessa condição se dá no último parágrafo do excerto, quando o narrador brasileiro faz as contas dos ganhos dos "jecas" dos Estados Unidos e do Brasil. Ora, esses cálculos de improviso, com fins de elucidação matemática imediata, à prova de refutação, eram o cerne das argumentações do britânico em Mister Slang e o Brasil. É inútil teorizar as intenções de Lobato ao confundir suas duas personagens, mas cremos que o que se prioriza aqui é a informação, o argumento que o autor não perde de vista e tenta provar de todos os jeitos: com citações, com comparações, com especulações, com fatos e, como dissemos, com a autoridade que a experiência pessoal parece conferir.

A notar também a citação ao Ford, o bem de consumo mais icônico e definitivo para Lobato. Como vimos no capítulo anterior, a respeito de $O$ presidente negro, possuir um carro pode ser um símbolo de ascensão social, que demarca quem “deu certo na vida”. Não obstante, aqui a imagem é de alguém de uma classe baixa econômica e que, ainda assim, ganhando decente e suficientemente, pode bancar rádio, algum luxo pessoal (charutos) e até um carro, não por acaso um Ford. O próprio Lobato é um dos exemplos, segundo Edgard Cavalheiro: "Quinze dias depois [de chegar aos Estados Unidos] escreve estar americanizado, possuindo automóvel, rádio, e um belo apartamento" (1955: 362).

O discurso parece claro: a produção em massa das indústrias Ford, de quem já sabemos Lobato grande admirador, significa para o escritor considerável democratização dos bens de consumo a adquirir: trabalhando o seu quinhão de oito horas diárias, o americano médio acredita que conseguirá comprar um automóvel Ford, diz o narrador lobatiano - a linha de produção das indústrias fordianas barateia o custo para fazer e comercializar o carro, tornando-o acessível a todos. É esse o discurso implícito de Lobato, viabilizado por um punhado de observações en passant de sua personagem anônima.

Acrescentemos uma citação de Ford coletada pelo biógrafo Richard Snow:

"Há milhares de homens lá na oficina que não estão vivendo como deveriam. Suas casas estão lotadas e o ambiente é insalubre... Eles alugam cômodos de suas casas para hóspedes na tentativa de ajudar a aumentar a renda familiar. Está tudo errado, tudo errado. Isso é especialmente prejudicial para as crianças... Agora, essas pessoas não estão vivendo dessa maneira por opção. É 
só lhes oferecer uma renda decente que elas viverão decentemente, com todo o prazer. Elas só precisam de uma oportunidade para melhorar, e que alguém que (sic) se interesse pessoalmente por elas, alguém que lhes mostre que acredita nelas" (2014: 257-8).

O discurso parece retirado de um colóquio com Mister Slang. Estão aí os temas caros à personagem e a seu criador, as "condições para prestar" ${ }^{54}$ que darão ao trabalhador decência, dignidade e, obviamente, poder aquisitivo.

Como aludimos, comentando as conclusões de Ida Tarbell acerca da mesma problemática $^{55}$, a complexidade da questão envolvendo simultaneamente as justificativas e procedimentos do método fordista não se esgota adotando-se um ponto de vista superficial e inflexível. O dirigente Charles E. Sorensen, da Ford Motor Company, sumarizou um dos mecanismos para decifrar as intenções e ações em disputa: "O sr. Ford estava dizendo que cada um deve ser o seu melhor cliente; que a menos que mantenha os salários altos e os preços baixos, o setor limita o seu número de clientes e se destrói” (2014: 258).

Melhorar a vida do trabalhador tem um caráter duplo, consequentemente: aumentando sua renda, o empregado pode consumir mais. Tanto para Ford como para Lobato, justifica-se uma espécie de "especulação consciente" do consumo (que garantiria clientes satisfeitos e circulação ininterrupta de produtos) pelas benesses econômicas, sanitárias e em certo ponto morais que o trabalho trará aos cidadãos e ao país - que só com moeda estabilizada e aquisição contínua de bens pode fazer a economia fluir e fortificar a nação.

Por fim, o ponto mais importante do excerto lobatiano, a questão da mecanização e da substituição da força humana bruta pelo maquinário industrial, não comporta nas letras do autor os efeitos críticos que os detratores da máquina imputam ou imputavam à sua utilização: para Lobato, a máquina não é causadora de desemprego que descambe em desajuste social: as funções "apossadas" pelas máquinas são toscas e merecem outrossim serem retiradas da esfera da ação humana; o desemprego é temporário e logo os trabalhadores dispensados devem ser alojados em outra colocação, mais digna do empenho humano ${ }^{56}$.

\footnotetext{
${ }_{54}^{54}$ Ver item 3.1.2 do presente estudo.

${ }^{55}$ Item 1.3 do mesmo trabalho.

${ }^{56}$ Este ponto é incontroverso na bibliografia de Monteiro Lobato - assim como para Mister Slang, é-lhe um fato evidente, gritante. Em sua literatura infantil, em um momento revelador de História das invenções (1935), Dona Benta quase parafraseia o inglês. Vide nossa análise da literatura infantil de Lobato, adiante neste trabalho.
} 
O procedimento empírico desenvolve uma dupla vertente em América: não apenas a crítica de quem "sabe", pois vivenciou uma condição, mas uma argumentação aprofundada na experiência de quem passou por aquilo que ora descreve. Possivelmente o maior exemplo disso na obra é seu deslocamento temporal: publicada em 1932, América passa-se quase que inteira antes da crise de 1929, que Lobato apanha in loco e por causa da qual sofre duros revezes econômicos. Segundo Edgard Cavalheiro:

\footnotetext{
"Hás de crer, escreve [Lobato] à irmã, que acabo de cometer um dos maiores erros da minha vida? Entrei no Stock Exchange com todos os recursos que pude reunir, certo de fazer fortuna. Errei o bote. Em vez de ganhar já perdi metade do meu capital e estou ameaçado de perder o resto e ainda ficar devendo alguma coisa. Estou resistindo, sempre com esperanças de que uma alta nos títulos ainda me permitam (sic) ao menos diminuir os prejuízos, mas não sei se poderei resistir muito tempo. O mais certo é perder tudo e ficar reduzido ao ordenado [de adido comercial]" (1955: 368).
}

Cavalheiro considera que "Pensado em 1929, escrito em 1930 e publicado em 1932, 'América' é um fiel retrato do entusiasmo de Monteiro Lobato pelo progresso americano. São raros os momentos de crítica ou censura" (1955: 370). Não coadunamos inteiramente com a o reparo, ainda que se deva reconhecer que mesmo a experiência traumática com a Bolsa de Nova Iorque sofre modificações para dar a entender que qualquer um como Lobato (ou Mister Slang) poderia antever o cataclisma financeiro antes de sua efetiva ocorrência, bastando para isso lucidez e a observação criteriosa do que ora se passava. Porém esses alertas foram produzidos em 1930, após a advinda do crack.

Deslocando a ação para antes da quebra da bolsa, as personagens vivenciam um mundo do qual já se sabe o resultado (catastrófico), porém antes que seus efeitos tenham ocorrido. Lobato usa suas experiências pessoais, nesse curioso relato de viagem, para fazer uma "previsão do passado". Estudar suas causas, entender os motivos da crise. A menção aparece rapidamente, de modo incidental, no capítulo XII, quando Mister Slang alude: “[Eróstrato] Está sendo citado neste ano de 1929, nesta America nem por sombras sonhada naquele tempo [a Antiguidade]" (1951a: 98).

O deslocamento causa certas incoerências internas na obra, como referir-se "antecedentemente" a eventos que ocorreram depois da quebra da bolsa ( 24 de outubro de 1929, ou 23, segundo Lobato [1951a: 265]) - a exemplo de The trespasser, que estreou em 11 de novembro de 1929: aludida sua première no primeiro parágrafo do capítulo XV - e explicitamente estabelecer a ação do livro (as viagens de Mister Slang e o brasileiro em terras americanas) em 1932 - no capítulo XXII, falando da proclamação da república em 15 de novembro de 1889, o narrador alude ao fato de que "estamos com quarenta e 
tres anos de perturbações revolucionárias" (1951a: 173). Entendemos que a ideia lobatiana é reforçar a retórica de seus argumentos e não puramente descrever o que viu nos Estados Unidos em uma cronologia acurada.

Observemos, pois, esse método em ação. No capítulo XXX, em que novamente torna a constar 1929 como o ano de ação (“-Em 1909 [a renda do povo americano] era de 35 bilhões de dolares. Está hoje, vinte anos depois, em 95 bilhões” [1951a: 246]), Mister Slang volta sua argumentação para a explanação das crises:

“- As crises são periodicas e não passam de estações de repouso e reajustamento. Já li a historia das crises americanas e até ando a deduzir a lei que as rege.

- A que as atribue?

- Inflação por abuso de credito. Especulação excessiva por excesso de credito. O excessivo abuso do credito dá origem a inumeros negocios de base aleatoria: a hipotese de que a progressão continuará na mesma marcha em que está vindo. Um abalo nesse alicerce (e eles abalam-se ciclicamente, em periodos de 8-10 anos) determina o fenomeno crise. Cái, e é varrido para o lixo como um castelo de cartas tudo quanto se ergueu sobre o alicerce precario. Saneamento. Poda de arvore. Limpeza dos galhos 'falsos'. Mas, passada a crise, a arvore mundificada continua a crescer com impeto maior do que antes.

E como falamos em crise, a conversa recaiu sobre a de 1922, uma das mais fortes que abalou o país. Mr. Slang havia acompanhado o seu desenvolvimento e até certo ponto a previra. O mesmo ia dar-se com a proxima. $\mathrm{O}$ meu arguto inglês via de todos os lados os sintomas da crise de 1929.

- A inflação está no apogeu, e inflação em escala nunca observada até aqui. A tempestade decenal aproxima-se, profetizou ele" (1951a: 246-7).

A crise de 1929 se localiza no passado para o Lobato escritor, e suas personagens, vivendo num momento anterior da história, podem prever o que só seria realizado posteriormente. Como na máxima cunhada por Sherlock Holmes (em adaptação nossa), “todo problema se torna infantil uma vez que é explicado" (2008: 886). Lobato teve condições de se inteirar das razões da crise, observar seus efeitos, verificar seus resultados.

De posse dessas informações, recua no tempo para demonstrar a previsibilidade da crise num momento anterior. Para isso, vale-se de recursos que explora textual e retoricamente. Seu maior trunfo é Mister Slang, ser de tanta ponderação que "via de todos os lados os sintomas da [iminente] crise de 1929"57. Mister Slang prevê a crise porque conclui que as crises são periódicas, que em todo decênio ocorre uma, que as situações se repetem e que todos os condicionantes se apresentam para em 1929 descambar em crise, a pior desde a que ele próprio (um empirismo “de personagem”) observou em 1922.

\footnotetext{
${ }^{57}$ No quinto capítulo analisaremos em boa medida o caráter "profético” de Mister Slang.
} 
Essa conformação é (apenas) possível em um dado momento da produção lobatiana. O escritor justifica a sabedoria quase onisciente de sua personagem, como vimos, em sua ponderação, raciocínio frio e pesquisa informativo-bibliográfica (“Já li a história das crises americanas") - todavia acreditamos ser ela viável, nesse aspecto, em face do que discorremos: a experiência empírica de Monteiro Lobato nos Estados Unidos.

Tanto não era algo tão evidente e cristalino, como Mister Slang dá a entender, que a crise sem precedentes não encontrou precaução ou defesa imediatas, como uma onda que cobriu inopinadamente a nação americana e, por via reflexa, o resto do mundo. Lobato, aqui representado talvez pelo brasileiro, foi outro que não teve a argúcia de Mister Slang e perdeu dinheiro na quebra da bolsa em 1929.

No capítulo XXXIII de América, finalmente eclode a crise. O narrador suspira: “Tivera razão Mr. Slang em ver maus sintomas na ansia com que os capitães da industria insistiam na nota de 'prosperity’ permanente e na extinção das crises cíclicas” (1951a: 265).

Nesse capítulo, repleto de cifras e números, fica clara a pesquisa do escritor em documentar bem os fatos, no melhor estilo Mister Slang, servindo-se de dados específicos para embasar seus comentários, tornar mais forte a argumentação e o expressivo das ideias veiculadas:

\footnotetext{
"Que é o Stock Exchange de New York? Dificil dar ideia... Um Monte Carlo onde o mundo inteiro especula em proporções absurdas.

Em 1929 as ações ali negociadas subiram á vertigem de 1.124.990.980, o que representa alguma coisa, sabendo-se que a $1 .^{\circ}$ de outubro o valor medio de cada ação era de 83 dolares. Além desse movimento de titulos houve ainda o movimento de "bonds", cujo total montou, para o mesmo periodo, em 3.200.316.700 dolares. Dia houve em que 16 milhões de ações foram negociadas, das onze horas ás tres...” (1951a: 266).
}

Ainda assim, essa checagem empírica encontra enfim seus limites. O objeto manejado demonstra impropriedades. Por mais que se apresentem fatos, números, cifras e dados, algo parece particularizado, fora da sensibilidade de um estrangeiro, distante da perfeita adequação a todas as realidades, pois exclusivamente próprio dos americanos. É o narrador brasileiro quem reconhece, no fim do mesmo capítulo:

\footnotetext{
"Mas, repito, é impossivel dar uma ideia do que é a especulação de titulos na America. Nisso, como em quase tudo mais, esta nação se mostra sui generis, unica, impossivel de medir-se por meio dos velhos estalões comuns á velha humanidade. Quem, por exemplo, pode medir o que representa uma redução de valores como a observada nos 18 dias de panico? Esse monstruoso sorvete que se derreteu - um sorvete de 50 bilhões, ou sejam 500 milhões de contos ao cambio de $10 \$ 000$ o dolar?

Tal soma representa 15 vezes a riqueza nacional do Brasil...” (1951a: 270-1).
} 


\section{AS IDEIAS AMERICANAS RESSURGIDAS NOS LIVROS INFANTIS}

\subsection{AVENTURAS “COM O PÉ NO CHÃO”: OS PARADIDÁTICOS}

A análise dos livros infantis de Monteiro Lobato, assunto quase invariavelmente presente nos estudos sobre o escritor e seus textos, relaciona-se a uma dimensão inescapável da obra autoral lobatiana. No escopo deste trabalho, contudo, verificar-se-á apenas pequena parte desse vastíssimo universo: as intersecções entre os discursos, tópicos e abordagens do que chamamos nos capítulos anteriores de trilogia americana do autor e os livros que editou depois para crianças, sobretudo os paradidáticos.

Importante ressalva: nos livros paradidáticos, como a própria abordagem conceitual o demonstra, o intuito implícito é instruir, ensinar, propagar conhecimentos que devem ser úteis à formação das crianças que formariam a base leitora daquelas histórias.

Outra ressalva: Lobato não escreveu às crianças livro algum sobre os Estados Unidos. As informações que encontramos no seu corpo bibliográfico infantil são pulverizadas em várias obras, com intuitos, efeitos e resultados diversos.

Muitos estudiosos subdividem a obra infantil de Monteiro Lobato em blocos temáticos, separando intenções, projetos e estilos. Míriam Gilberti Páttaro relembra a proposta de João Carlos Marinho, que Edmir Perrotti retoma, constituída em

\footnotetext{
"dividir a obra lobatiana em três grupos. [Marinho] Acredita ser possível tal classificação devido à consciência que Lobato tinha da distinção entre literário e didático, estético e utilitário. O primeiro grupo envolve as obras em que há uma história livre ou bem casada com propósitos didáticos. É o caso, por exemplo, de Reinações de Narizinho. O segundo grupo é formado por aquelas obras em que há predomínio de intenção didática e 'não há literatura', a obra História do mundo para as crianças está incluída nesse conjunto. E, finalmente, o terceiro grupo abrange as 'histórias fora do sítio, contadas nas reuniões do sítio, onde um personagem, geralmente Dona Benta, é narrador, e os demais são ouvintes e palpiteiros'. É o caso da obra Fábulas, entre outras. Marinho é taxativo quanto ao segundo grupo: 'Estamos declaradamente fora da literatura, são compêndios escolares com pretensões de originalidade' (apud Perrotti, 1986, p.64)" (2009: 226-7).
}

Nossa proposta apoia-se em separar, grosso modo, a obra infantil de Monteiro Lobato em dois blocos de abordagem, quais sejam, os "livros de fantasia" e os "livros de ensinamentos", com considerações importantes a fazer.

Não pretendemos aprofundar a discussão, daí usarmos apenas nossa pessoal e global classificação, com as devidas restrições, posto que os rótulos sejam apenas guias 
para análises. Tais diferenciações não são nem mesmo definidas ou usadas, em qualquer medida, pelo autor da série de livros em questão.

Como representantes da categoria de fantasia, temos, entre outros, os volumes Reinações de Narizinho, Caçadas de Pedrinho, Memórias da Emília, A reforma da natureza e A chave do tamanho. Os volumes de ensinamentos desdobram-se em dois subníveis: as "recontações" de histórias já existentes, como Fábulas, Aventuras de Hans Staden, Peter Pan e Dom Quixote das crianças, um "repertório cultural" que o autor entendia por bem passar às crianças; e os paradidáticos, verdadeiros compêndios escolares cuja explanação dos conteúdos programáticos escolares é capitaneada pela turma do Sítio: exemplos são Aritmética da Emília, Emília no País da Gramática, Geografia de Dona Benta, Serões de Dona Benta, O poço do Visconde.

A classificação que propomos é discutível e suas fronteiras são tênues. Há obras que podem se encaixar em mais de uma etiqueta: Emília no País da Gramática é tanto um paradidático por direito, com aulas e noções da gramática normativa, como uma aventura numa terra exótica repleta de criaturas curiosas; Geografia de Dona Benta pode ser tido como aula (livro paradidático), viagem (livro de peripécias) e releitura de livro já existente $^{58}$; Os doze trabalhos de Hércules desdobra-se em viagem, aula sobre mitologia, recriação de histórias conhecidas; e por aí adiante. A obra infantil de Lobato possui uma profusão de vertentes e caminhos de experimentação e desenvolvimento.

No entanto, cabe constatar que certas "linhas delineadoras" se fazem presentes na maioria dos livros da coleção infantil lobatiana. À parte o hibridismo de gêneros, o tom do livro e sua ambição imediata define-se, costumeiramente, de modo bastante claro. Viagem ao céu narra aventuras fictícias, lúdicas, História das invenções apresenta-se rigidamente como uma exposição de saberes "reais".

Sabendo que os livros de Lobato eram muitas vezes adotados por escolas Cavalheiro: “espantoso fato: (...) impor-se [Narizinho arrebitado] de maneira a levar o Govêrno do Estado, tão pouco preocupado com tais assuntos, a adquirir grande parte da tiragem para distribuí-la gratuitamente aos alunos dos grupos escolares" (1955: 325) -, a ambição de seus livros paradidáticos se reveste de mais facetas: seriam informações que o escritor desejava passar "oficialmente" a seus pequenos leitores, junto aos conhecimentos técnicos que eles deveriam apreender dos conteúdos programáticos didático-pedagógicos normais.

\footnotetext{
${ }^{58} \mathrm{O}$ caso será comentado mais adiante neste capítulo.
} 
O que chamamos de intersecções tem, portanto, uma carga ideológica que vai além da narratividade de uma história ficcional. J. Roberto Whitaker Penteado, pesquisador dos efeitos da ideologia na literatura infantil lobatiana, anota que, “especialmente nos livros 'paradidáticos', Lobato aproveita as oportunidades que aparecem para transmitir aos pequenos leitores que o país não é bem administrado" (2011: 219). O escritor desejava incutir em seu público mirim noções realistas, cívicas, políticas, econômicas. Feito quisesse transformar cada leitor-criança em uma das indagadoras criaturas de suas histórias.

Relevante salientar que nos livros paradidáticos Lobato adota de modo geral uma estrutura mais estática, que consiste normalmente em uma personagem que se apodera do discurso principal - usualmente Dona Benta - e que explana conceitos, situações e fatos às outras personagens. São histórias mais planas, mais "pé no chão", em que a fantasia é domada, ou antes domesticada: o absurdo causa espanto, não é da ordem do dia.

Um exemplo pontual: em História das invenções (1935), Pedrinho diz, após receber da avó informações sobre o uso de escafandros: “- Está aí, uma coisa que eu queria ter (...). Um escafandro! Deve ser interessantíssimo andar num fundo d'água. Quanta coisa esquisita! E no fundo do mar, então? Que maravilha...” (2017a: 53). Não só nenhuma personagem que também está na cena (Dona Benta, Narizinho e Emília) o corrige, considerando a sabida aventura do menino, em uma das histórias de Reinações de Narizinho, no Reino das Águas Claras (um reino no fundo da água), como a avó acrescenta que ao homem não foi dado descer a grandes profundidades marítimas por causa da pressão d'água!

Outro exemplo elucidativo, dos Serões:

"Emília olhava para o céu.

— Lá está a Via Láctea - disse ela apontando, sem medo nenhum de criar verrugas. - Lá estivemos brincando de fazer estrelinhas e cometas com a massa de astros que aquilo é! Lá eu...

- Pare com os mitos - murmurou Narizinho. - Nós agora só queremos ciência. Explique o que é a Via Láctea, vovó.

Dona Benta apontou para certo ponto do céu.

- É aquilo esbranquiçado que vemos lá em cima. Os sábios chamam a essas massas esbranquiçadas Galáxias, e as consideram enormes acumulações de estrelas no espaço" (2014b: 141).

Emília tenta trazer para o serão uma experiência empírica que todos ali (exceto Dona Benta) tiveram, no livro Viagem ao céu. Ao relembrar peripécias cósmicas da turma, no entanto, é desautorizada por uma sua colega de viagem, Narizinho, que descarta esse saber "sentido" em prol do saber "narrado". Agora as aventuras que elas vivenciaram 
são mitos. E agora eles "só querem ciência", que é claramente uma outra noção, distante da de mito. Emília se cala, sem vontade de discutir.

Aparentemente, ela própria concorda com o "remate". Ainda assim, no mesmo livro, páginas adiante, indaga sobre um planeta específico: “—E o Saturno dos anéis? — perguntou Emília. Nós já estivemos lá, no tempo da Viagem ao céu, brincando de escorregar naquela aba de palheta. Mas quando a gente está muito perto de uma coisa não a vê no conjunto. Conte a história de Saturno, Dona Benta" (2014b: 150).

Tanto Emília quanto Narizinho usam do mesmo expediente: falam do mito - em suas várias acepções: folclórico-mitológica, experiência lúdica - para estabelecer um contato pessoal que sirva de ponte ao saber autorizado da ciência. Ambas as personagens pedem auxílio a Dona Benta para complementar seus saberes. Seja ignorando as aventuras fantasiosas (Narizinho) ou usando-as de ponto de partida (Emília), faz-se necessária a intervenção da ciência oficializada, pelo canal mais adequado: a avó, que curiosamente é a única ali presente que não tomou parte nos passeios pelo espaço. Ela sintetiza: "As coisas da ciência têm de ser como as da escrituração mercantil: certíssimas" (2014b: 151).

Esse tipo de ocorrência cria certamente problemas de coesão interna na coleção de histórias infantis de Monteiro Lobato. As personagens desautorizam, criticam, negam, rejeitam aventuras e fatos que vivenciaram em obras anteriores. Dona Benta, anos após encontrar o saci em pessoa (em eventos narrados no livro $O$ saci), agora tem, peremptória, outra visão:

“- Os redemoinhos são formados pelos sacis que corropiam como pião disse Emília.

Dona Benta contestou.

— Essa explicação, Emília, é popular, não científica. Saci só existe em cabeça de negro velho. É sempre a convecção que produz tais ventos, com ou sem redemoinho - mas sempre sem saci dentro. E tais ventos podem ser uma coisa de nada, como as brisas, ou uma coisa horrorosa, como os ciclones.

— Fale dos ciclones, vovó - pediu Narizinho. - Não tenho a menor ideia desses monstros" (2014b: 118).

Esse excerto dos Serões repete a estrutura dos anteriores, incluindo uma das personagens (Narizinho) desconsiderando a vivência lúdica experimentada anteriormente (a menina foi salva, pelo Saci, de um encantamento da Cuca) e pedindo a explicação científica para a avó.

Fica claro, portanto, que Lobato, nos livros paradidáticos, não se importa com esses problemas de coesão e coerência internos na série. O que busca é o argumento que pode convencer ao leitor ou aproveitar a ele, enquanto autor. Whitaker considera que 


\begin{abstract}
"O estudo da ordem e da cronologia das obras, confrontado com a natureza e o conteúdo de cada uma, bem como a intertextualidade com escritos paralelos, sobretudo nas cartas que enviou a diversas pessoas, coletadas em livros e artigos, prefácios e entrevistas, são fortemente indicativos de que Lobato agiu de maneira deliberada e tinha como objetivo transmitir seus próprios valores, de forma persuasiva, aos jovens leitores" (2011: 240).
\end{abstract}

Os livros paradidáticos de Lobato trabalham em outra ordem de verossimilhança. Ainda que os elementos de fantasia estejam presentes a cada página (sobretudo pelas presenças “inexplicáveis” de Emília, Quindim e o Visconde de Sabugosa), o formato algo modesto da estrutura das histórias (explanações e intervenções, perguntas e respostas) impede grandes voos de imaginação.

O que aparece nesses livros, portanto, é o que deve ser apre(e)ndido, sem grandes malabarismos mentais. Ou é essa a ideia do escritor, que apresenta os livros como verdadeiras aulas (ou serões, o termo preferencial), o que não escapava à argúcia de seus leitores mirins, que identificavam os conteúdos escolares nas aulinhas do Sítio - e eram gratos por isso, como demonstram muitos depoimentos em cartas ao escritor (in Edreira):

\footnotetext{
"Alariquinho, filho de Alarico da Silveira, secretário do Interior quando da compra dos milhares de exemplares de Narizinho arrebitado pelo governo do estado de São Paulo, afirma que Emília no país... ajuda muito no estudo da gramática. Diz que só aprendeu o que a professora pediu depois de sua leitura: "Você fez bem em escrever este livro porque eu estou estudando gramática que é a coisa mais cacete do mundo. A professora mandou decorar uns verbos e quando eu li o seu livro aprendi tudo".

A leitora que se identifica como "Rã-sizuda" descreve o que pretende fazer na aula a partir do que aprendeu com o livro, mostrando outra aluna levando idéias do autor para a escola: "Amanhã é dia de português. Vou outra vez boquiabertar o teacher. [...] Falarei [...] sôbre a modificação das palavras e sôbre a natural inclinação dela para a mais fácil linguagem - mais fácil e mais preguiçosa".

Haroldo, leitor de 13 anos, comenta a opinião de seu tio, que ressalta a facilidade com que se aprende com o livro: "Um tio meu me disse que só há um meio "canja' de aprender gramática: é ler 'Emilia no país da Gramática"'. Gilson, aos 10 anos, ressalta que leu o livro logo assim que comprou e aprendeu muito com ele: "Chegando em casa fui logo começando à ler. Aprendi 'abéssa"'. Assim como Edite, que afirma de passagem: "Não é por dizer, mas eu aprendi e compreendi gramatica com o seu livro" (2004: 30-1).
}

Não são propriamente obras de aventuras, a despeito de certas artimanhas lobatianas: a Geografia de Dona Benta se passa "in loco" numa viagem pelo mundo, em Emília no País da Gramática as palavras da gramática normativa são cidadãos de uma nação imaginária etc.

Os livros paradidáticos lobatianos são, assim, um projeto mais sóbrio de comunicação, direto, sem maiores disfarces. Muitas vezes são versões de livros já existentes, como História das invenções é a releitura declarada da obra The story of 
inventions: Man, the miracle worker, publicada um ano antes pelo neerlando-americano Hendrik van Loon (1882-1944).

Lobato, editor arguto, atentava ao que saía de mais inovador na seara dos livros de instrução e paradidáticos. Muitas vezes publicava ao mesmo tempo a tradução da obra original e sua própria versão, como História do mundo para as crianças (1933), baseado em $A$ child's history of the world, de V. M. Hillyer (1924), que Lobato publicaria com tradução de Godofredo Rangel pela Companhia Editora Nacional, sob o título Pequena história do mundo para crianças.

Ainda que evidentemente inconclusivas, cabem reflexões sobre os intuitos desses livros paradidáticos, ou antes sobre seus aspectos e abordagens. Tendo alegadamente, nos anos 1930, desistido de escrever sistematicamente para adultos ("De escrever para marmanjos já me enjoei”, como citamos em nosso primeiro capítulo), por que Monteiro Lobato repete suas ideias dos livros adultos, com as devidas proporções, nas obras infantis? Quais os sentidos e especificidades de repetir considerações em textos dedicados a públicos diferentes? O que isso acarreta na exposição das ideias, no desenvolvimento das idiossincrasias e, sobretudo, no sentido prático a que a retórica lobatiana se associa ao "pregar" para alvos determinados, escolhidos pelo escritor?

Uma consideração importante reside no desdobramento de um ponto que indagamos reiteradamente: o que na trilogia americana há de perene, para que o escritor se preocupe em falar duas vezes? As três obras sobre os Estados Unidos ressentem-se em dada medida de um "imediatismo" que torna as críticas ao Brasil e os elogios à terra americana algo perecíveis.

No entanto, como explicitaremos adiante ao investigar a coleção desses títulos nas Obras Completas que Lobato organizou, o sentido mediato dos textos não era desconsiderado pelo escritor, e há muito que se extrair dos livros à parte o que se aproveitaria com mais força na discussão contemporânea a eles. Em outras palavras, se Lobato se preocupou em deslocar certas coisas dos livros adultos e enxertá-las na obra infantil, ele visava a certas estratégias e efeitos consideravelmente duradouros ou assim pretendidos.

É mister perceber que as obras infantis são escritas em momento posterior da obra de Lobato e, em última análise, o próprio escritor as considerava sua visão definitiva das coisas - em carta aberta ao Ministro da Agricultura, encontrada em $O$ escândalo do petróleo, apresentou-se como "um humilimo escritor de livros para crianças" (1951b: 75) - e uma espécie de testamento autoral, o conjunto de livros pelos quais eternizou suas 
ideias últimas, na fase final de sua vida: "Estou condenado a ser o Andersen desta terra. (...) Que mundos diferentes, o do adulto e o da criança! Por não compreender isso e considerar a criança 'um adulto em ponto pequeno' é que tantos escritores fracassam na literatura infantil e um Andersen fica eterno" (2010a: 554-5).

A coincidência de temas, assuntos e até tratamentos pode então não ser considerada ocasional, mas deliberada. Os conteúdos encontrados nos livros infantis formariam uma confluência com o pensamento adulto do escritor, pois, como Lobato mesmo se daria conta, "o curioso é que o Sítio do Picapau Amarelo já passou a remédio de gente adulta" (2010a: 552). Os públicos muitas vezes se intercambiavam, mas a mensagem lobatiana seria clara e inteligível a qualquer leitor. Um projeto literário consciente, portanto, com uma metodologia acurada, ainda que livre e espontânea.

Certa inflexibilidade na estruturação das aulas-serões serve também ao propósito pensado na obra adulta do escritor de tratar, aos poucos, de "pílulas" de saber, informações dosadas com parcimônia, numa organização bastante pontuada. Apontamos em nosso capítulo 3 as conclusões dos colóquios seriados entre Mister Slang e seu amigo brasileiro, e fazemos notar aqui que o efeito se repete quase identicamente nos livros paradidáticos.

Enquanto a aventura não tem fim (nos livros de fantasia), por assim dizer, as aulas e explanações são mais rígidas na forma e mais centradas na assimilação: os capítulos dos colóquios, em Mister Slang e o Brasil, são encerrados com "golpes de cena" simples ou simplórios como o resultado de uma partida de xadrez ou uma observação irônica, arguta, que marca decididamente o final daquele ponto, como um professor que se despede dos alunos ao final de uma aula. Nos livros infantis paradidáticos, após alguns tantos capítulos ou páginas, interrompe-se a "contação" ou serão por ação de algum evento externo ou pelo próprio desejo do orador da vez, detentor da voz de comando: Dona Benta, em seus serões, não cansa de afirmar para os netos que já está tarde, que é hora de dormir, que agora deverão comer a janta preparada por Tia Nastácia e assim por diante.

\subsection{PERSONAGENS, ABORDAGENS E RESULTADOS}

Os efeitos de diferentes abordagens retóricas, da utilização de personagens variadas e o contexto que o autor pensou para seus livros paradidáticos têm relevância, necessitando acurada averiguação. Segundo nossos apontamentos, esquadrinhados em diversos momentos deste trabalho, as características específicas de cada personagem 
escolhido para veicular uma ideia ou comunicar um fato servem a propósitos igualmente específicos.

Observemos o início de História das invenções, quando Dona Benta pega um livro de Van Loon para lê-lo à criançada:

"Dona Benta costumava receber livros novos de ciência, de arte, de literatura. Era o tipo da velhinha novidadeira. Bem dizia o compadre Teodorico: 'Dona Benta parece velha mas não é, tem o espírito mais moço que o de muitas jovens de 20 anos'.

Assim foi que naquele bolorento mês de fevereiro em que era impossível botar o nariz fora de casa de tanto que chovia, resolveu contar aos meninos um dos últimos livros chegados.

- Tenho aqui um livro de Hendrik Van Loon — disse ela —, um sábio americano, autor de coisas muito interessantes. Ele sai dos caminhos por onde todo mundo anda e fala das ciências de um modo que tudo vira romance, de tão atrativo. Já li para vocês a geografia que ele escreveu e agora vou ler este último livro - História das invenções do homem, o fazedor de milagres.

Era um livro grosso, de capa preta, cheio de desenhos feitos pelo próprio autor. Desenhos não muito bons, mas que serviam para acentuar suas ideias.

(...)

- Este livro não é para crianças — disse ela —, mas se eu o ler do meu modo vocês entenderão tudo. Não tenham receio de me interromperem com perguntas, sempre que houver qualquer coisa obscura" (2017a: 12).

Verdadeiro credo do que Lobato entendia como a "função" de seus livros paradidáticos infantis, o excerto traz uma pletora de informações elucidativas de seus métodos, abordagens e intenções.

A autoridade da personagem-contadora (Dona Benta) reveste-se de insígnias de legitimidade: Dona Benta é informada, recebe sempre livros novos, é uma "velha novidadeira". Não fala por "ouvir falar", ao contrário: informa-se muito bem sobre as coisas. Também é uma senhora idosa, experiente, que sabe filtrar os conhecimentos que julga adequados passar. Faz as vezes aqui, portanto, de mediadora entre o conhecimento que recebe e o que deseja passar adiante.

"Ciência, arte, literatura": os saberes da boa senhora englobam muitas áreas do conhecimento humano, ficando claro que os três campos são apenas exemplos entre muitos outros. A velha novidadeira procura saber de tudo, e é ela, novamente valendo-se de sua legítima autoridade, que decide, na qualidade de mediadora, o que comunicar aos seus "alunos".

Aproveitando a circunstância externa da chuva, Dona Benta resolve contar as "coisas muito interessantes" de um dos últimos volumes que recebera, que já referenciamos: The story of inventions: Man, the miracle worker. Nas histórias lobatianas, o conhecimento dos livros pode ser tanto pedido pelas crianças quanto decidido por quem o conhece (normalmente, Dona Benta). 
Esse procedimento cria um efeito de integração e aproximação: tanto o adulto pode decidir contar algum saber que não havia sido, em princípio, imaginado para crianças, quanto pode a criança ela mesma indagar sobre um desses saberes que lhe são “escondidos”. É o caso, por exemplo, de Emília em Dom Quixote das crianças, onde os austeros volumes traduzidos da obra de Cervantes, enormes e ameaçadores, estão no topo da estante da biblioteca. Emília, curiosa, faz Dona Benta contar com suas palavras a história da personagem.

Essa operação de dupla via tem conotações importantes. Na interação entre adulto e criança a experiência "contadora" apresenta-se como verdadeira troca. Tanto o adulto esclarece, clarifica ou explica quanto a criança colabora, participa, indaga. Dona Benta explicitamente informa que não há problema nas intervenções: "Não tenham receio de me interromperem com perguntas, sempre que houver qualquer coisa obscura".

Age, assim, como professora nessas aulas-serões. Com autoridade e legitimidade, atributos inerentes a sua figura de expositora das novidades científicas, mas com espaço para a participação livre dos mais jovens, que não possuem sua bagagem cultural e, evidentemente, sua provecta idade, mas que podem engrandecer o debate com novas facetas e perspectivas.

Imprescindível, contudo, trabalhar a abordagem com que os ensinamentos serão comunicados. Ler o livro apenas, em voz alta, para as crianças é inútil. O livro não foi escrito para elas, as informações terão problemas para alcançá-las, haverá ruídos e defasagens. Dona Benta, experiente, sabe que "este livro não é para crianças". Em vez de descartar a obra, resolve torná-lo para crianças, lendo de seu modo - a avó sabe como são seus netos e o que os impressiona, motiva e impacta. Sabe o que é preciso fazer para deixá-los interessados e despertos. Sabe, enfim, o jeito para os conteúdos tidos como para adultos serem assimilados pelo público infantil.

Pertinente relembrar as considerações que a poetisa e educadora Cecília Meireles faz acerca desse procedimento:

\footnotetext{
"De modo que, em suma, o 'livro infantil', se bem que dirigido à criança, é de invenção e intenção do adulto. Transmite os pontos de vista que êste considera mais úteis à formação de seus leitores. E transmite-os na linguagem e no estilo que o adulto igualmente crê adequado à compreensão e ao gôsto de seu público. Nessas condições, qualquer tema, de suficiente elevação moral, exposto em forma singela e correta pode transformar-se num livro infantil” (1951: 35).
}

O livro infantil, assim, relaciona-se ao conhecimento, de qualquer esfera e tipo, passado para as crianças, nas suas chaves e códigos - mas que, pela própria ontologia da 
criação textual, será necessariamente selecionado, escolhido, filtrado, mediado ou produzido por um adulto.

Indubitável que aqui não é apenas Dona Benta que vai ler o livro adulto "do seu modo" para os pequenos entenderem, mas também Monteiro Lobato. O autor da releitura, em última instância, é o escritor, que movimenta suas personagens de modo a veicular suas ideias de maneira palatável ao público alvo.

Inquestionavelmente um dos grandes méritos da obra infantil lobatiana é a destruição da barreira de sisudez entre o que os adultos devem falar e o que as crianças devem aprender. Se as crianças discordam, questionam, podem ter voz para falar e se pronunciar. Seus apartes podem ser ignorados (como as insistentes intervenções humorísticas da Emília) ou levados em conta e usados para aprofundamento das discussões. O que importa é dar voz à criança, dar espaço para ela refletir e participar.

Nisso, acordam estudiosos vários, a literatura de Lobato se torna uma voz pioneira no Brasil, onde as crianças retratadas discutindo com adultos eram, anteriormente aos livros do Sítio, pequenos adultos sem espontaneidade, que acatavam conhecimentos de forma passiva e sem qualquer indagação. Autores como Olavo Bilac e Coelho Neto, contemporâneos de Lobato, faziam de suas crianças praticamente títeres que serviam apenas de vaga pontuação para a disposição das ideias de adultos, que em pouco concerniam realmente ao mundo infantil. Segundo Nelly Novaes Coelho:

\footnotetext{
"Em todos os títulos didáticos ou paradidáticos assinados por Olavo Bilac e colaboradores, estão evidentes as ideias humanitárias e as tendências pedagógicas dominantes no momento: o naturalismo cientificista; a admiração, abnegação e o amor pela pátria (o que redunda, o mais das vezes, no patriotismo retórico e ufanista, na linha do 'Por que me ufano do meu país', de Afonso Celso, em 1900); a exaltação do humanitarismo (ou do paternalismo); a valorização do trabalho como dignificação do pobre (idealizado sempre como alguém abnegado, ignorante, resignado com as limitações de sua vida, mas resistente, forte, simples e feliz...); a responsabilidade social; o comportamento adequado a cada situação; as lições contra os vícios (a inveja, indolência, mentira, ambição, violência, avareza etc.)...” (2006: 38).
}

Ou seja, os livros destinados para as crianças eram em suma conhecidos por seus conteúdos moralizantes e moralistas, com noções cívicas que deveriam ser acatadas e jamais questionadas pelos seus leitores. Depois de Lobato e sua influência sem precedentes no mundo das letras infantis funcionando como divisor de águas, o quadro se alterou substancial e perenemente.

As próprias crianças-personagens reconhecem o mérito desse ambiente mais democrático de exposição de conteúdos. Narizinho, após uma explicação sobre arremesso 
de projéteis na História das invenções, observa: "Não há o que a gente não compreenda quando a senhora explica, vovó".

A observação, curta e direta, serve também como um lembrete do pacto proposto por Dona Benta/Lobato: a dificuldade na apreensão dos assuntos deve ser dirimida pela boa convivência e relação entre professora-avó e aluno-neto. Caso Narizinho não entendesse a matéria, Dona Benta punha-se a explicar novamente, partiria para mais exemplos, mudaria o método. Os exemplos abundam nos paradidáticos lobatianos:

“- Outro gênio do mesmo tipo descobriu que segurando uma pedra e arremessando-a conseguiria atingir um objeto que estivesse longe de si. Outro progresso imenso, do qual iam sair até os canhões de hoje.

- Como, vovó?

— Espere. Sem que eu explique você irá compreendendo. Antes de aprender a arremessar a pedra, o homem tinha o poder dos músculos limitados ao comprimento dos braços. Quer dizer que só podia no raio de um metro mais ou menos.

— Não estou entendendo muito bem esse raio aí...

- Raio é a metade do diâmetro de um círculo. Isso você sabe. Pois bem: antes de aprender a arremessar a pedra, o peludo era como se estivesse no centro de um círculo de dois metros de diâmetro, seus braços formavam os raios desse círculo, de modo que ele só podia atingir o que estivesse dentro de um raio do comprimento do seu braço, isto é, um metro.

— Bom, agora entendi" (2017a: 45-6).

Pedrinho interrompe a avó, algo inutilmente: “Como, vovó?”. Ela não se zanga, diz que se ele ouvir tudo irá entender por ele mesmo: "Sem que eu explique você irá compreendendo". Novamente o neto interrompe a explicação "Não estou entendendo". A avó, paciente, complementa e esclarece o conceito (raio, diâmetro, metro). A criança dáse por satisfeita, afinal: "Agora entendi”.

Operação repetida inúmeras vezes na obra paradidática de Lobato, de estrutura simples, cognoscível a qualquer leitor e que reflete o princípio pedagógico que ora dissecamos, com a criança fazendo todas as intervenções que julga necessárias para apreender o conteúdo que antes era restrito ou codificado a adultos.

Assinale-se importante ponto: um tanto quanto artificial, a definição de Dona Benta como "cientista", a explicar noções de tratados e teorias científicas, serve a interesses bastante precisos da parte do autor.

Se em "Reinações de Narizinho" Lobato define a avó como uma senhora meio sozinha no campo, sem grandes distinções de espécie de que seja - o famoso começo do livro: "Numa casinha branca, lá no Sítio do Picapau Amarelo, mora uma velha de mais 
de sessenta anos..."59 (2015c: 11) -, e em uma das histórias do mesmo volume chega a citar que a senhora, "de tanto contar histórias ficou que nem bagaço de caju; a gente espreme, espreme e não sai mais nem um pingo", razão por que "teve de escrever a um livreiro de São Paulo, pedindo que lhe mandasse quanto livro fosse aparecendo" (2015c: 243), fica difícil acreditar na científica e engenhosa avó que explica as noções dos Serões, as epopeias tecnológicas de História das invenções e todos os conceitos da Geografia.

Talvez o procedimento se torne mais palatável se considerarmos cada livro da coleção como uma obra essencialmente "isolada", interligada às demais por intersecções que não ultrapassam o volume diegético de cada livro: as personagens se ligam, não as histórias, nem mesmo os acontecimentos. Como se cada livro trouxesse em si todos os elementos de sua constituição e desenrolamento, não podendo serem buscadas em outro volume as especificidades de outra obra, mesmo se as conexões por vezes se fizerem explícitas $^{60}$.

Não obstante, a escolha de Dona Benta como porta-voz dos saberes científicos tem, nesse momento, objetivos específicos que, a nosso ver, são muito felizes. Vejamos: se é preciso passar às crianças saberes "oficiais", não há cabimento em esperar que elas, ainda que inteligentes, já os possuam; logo, alguém precisa comunicá-los. Há no mundo do Sítio duas possibilidades: o Visconde de Sabugosa e Dona Benta. Por que Lobato prefere Dona Benta quase sempre?

O Visconde, nas aventuras lúdicas, como Reinações de Narizinho e Viagem ao céu, não raro reveste-se de certo humorismo, tornando-se alívio cômico e alvo preferido das estripulias de Emília. Nos livros paradidáticos, diferentemente, tem, por sua condição ontológica de sábio, um papel mais vetusto, de depósito de conhecimentos: é dele, na realidade, a aritmética “da Emília”, é ele quem ensinará geologia ao pessoal do Sítio.

\footnotetext{
${ }^{59}$ A gênese da mais famosa obra infantil de Lobato nos mostra uma Dona Benta ainda mais "frágil". Lobato alterava muito suas obras em revisões posteriores, e a primeira versão do famoso parágrafo não deixava dúvidas sobre Dona Benta estar o mais longe possível da noção que teríamos de uma cientista, assemelhando-se mais a uma decrépita velha interiorana: "NAQUELLA casinha branca, - lá muito longe, móra uma triste velha, de mais de setenta anos. Coitada! Bem no fim da vida que está, e tremula, e catacega, sem um só dente na boca". Na atualização, atenua-se a descrição física da personagem, mas ainda assim é uma pacata senhora, "com uma cestinha de costura no colo e óculos de ouro na ponta do nariz". Os trechos foram compilados por Rosane de Bastos Pereira (2018).

${ }^{60}$ Por exemplo, certos livros possuem alusões escancaradas a outros, principalmente os que são mesmo concebidos como "continuações" de aventuras anteriores: Viagem ao céu prossegue a ação de Reinações de Narizinho, O Minotauro retoma eventos descritos imediatamente antes em O Picapau Amarelo, a viagem à Grécia de Os doze trabalhos de Hércules traz inúmeros ecos, comentados pelas personagens, de "sua primeira viagem à Grécia" (em $O$ Minotauro)...
} 
Como dissemos, nos livros paradidáticos, Lobato "fala sério", sem tanto espaço para a invenção e a brincadeira.

Mas a eleição de Dona Benta como fonte preferencial da erudição que Lobato entende importante passar às crianças tem conotações próprias. Para começar, Dona Benta, enraizando ainda mais "no mundo real" as aulas, é um ser humano, sem qualquer fantasia em sua construção; uma aula passada por um sabugo que fala pode ser ótima, mas não deixa de ser atrelada a um ente essencialmente fictício, imaginado. Escolher a senhora como portadora das novidades reveste aqueles conhecimentos de maior "austeridade", o que mais se adequa aos conteúdos e matérias que devem ser abordados e assimilados.

Mieke Bal, teórica literária, destaca nas narrativas três agentes: ator, focalizador e narrador. Detenhamo-nos um pouco no segundo, que nos parece bem o caso de Dona Benta. Juliane Nadal Cavalheiro da Silva explica que "O focalizador é o sujeito da focalização expressado por Mieke, e que este contempla os elementos tanto dentro quanto fora da fábula" (2013: 3). Entendamos o focalizador como a ponte entre o ator (aquele que age ou interage) e o narrador (aquele que conta). Sendo o responsável pelo foco narrativo, não é o focalizador que dá a medida do que se mostra e como se apresenta uma história ou narrativa?

Em casos como o do focalizador-personagem (como Dona Benta), Silva esclarece que

\footnotetext{
"Bal estabelece a relação entre o que se vê e o que se percebe e faz a distinção para a relação dentro da focalização entre o agente que vê e o que se vê. Tais componentes da história fazem parte dos componentes do texto narrativo. A focalização é um elemento importante na narrativa que não se pode ver o significado de certos aspectos a menos que sejam vinculados à ela. A focalização é, para a autora, o meio de manipulação mais importante, mais sutil e mais penetrante, pois quando se apresentam os acontecimentos se faz necessária uma certa concepção e para isso se elege um ponto de vista: "O agente que vê deve receber uma característica diferente do agente que narra". (BAL, 1990, p.50). O sujeito da focalização contempla os elementos dentro da fábula ou fora dela e o focalizador pode ou não ser personagem. Quanto aos níveis de focalização, Bal destaca que há vários níveis de focalização, e que não há diferenças entre uma narração de primeira pessoa ou de terceira. A Focalização Interna, segundo a autora, é quando o agente participa da fábula, dando vida aí a um Focalizador Personagem (FP) - (eu ou ele). Na Focalização Externa, ela discorre dizendo que quando um agente de fora opera como focalizador passa a ser um Focalizador Externo (FE).

Mieke Bal destaca que a visão do focalizador personagem (FP) se dá "dentro" da visão do FE e que existe a focalização intercalada, onde esta pode voltar ao primeiro nível a qualquer momento. Na denominada narração de primeira pessoa há um FE, normalmente um "EU" que um tempo depois oferece sua visão de uma fábula em que tenha participado anteriormente na qualidade de
} 
ator. Na questão dos níveis, quem permite a quem observar a quem se dá na relação entre sujeito e objeto focalizado" (2013: 4).

A escolha de uma personagem de seu corpus para passar os conceitos dos livros paradidáticos e guiar a linha de ação nessas obras gera, portanto, efeitos importantes dentro das narrativas. Uma personagem que participa da ação a narrar alguma história tem um sentido de focalização relacionado à própria experiência, ao costume, a uma visão com bem menos distanciamento.

Personagem "de dentro da fábula", Dona Benta tem "mais" o que falar do que o teria uma figura alheia àquele mundo ficcional já estabelecido. Como uma mediadora a mostrar as coisas às crianças - e, em escala maior, como Lobato fazendo o mesmo com seus leitores mirins -, a boa avó tem como um olhar ao mesmo tempo de personagem e de não personagem. O que nos leva novamente aos problemas "de contradição" entre os saberes experimentados e autorizados, como se só parte das aventuras vividas fosse digna de eternização via aulas, serões e explicações, e o restante fosse apenas uma fabulação gostosa, porém de um saber questionável, essencialmente lúdico.

A escolha de Dona Benta, como de resto a do próprio Visconde, tem também um importante sentido retórico. Lobato poderia ter escolhido, o que sem dúvidas soaria menos artificial, uma personagem "de fora" para explicar as coisas que suas criaturas comentam. Digamos, um cientista poderia fazer uma visita ao Sítio, um professor qualquer, um sábio de renome, e lá contar à turma suas observações. Mas Lobato bate o pé e teima: será uma de suas personagens a fazê-lo.

Como aludimos, isso cria uma artificialidade inerente ao relato. Qualquer um pode indagar, tendo lido as aventuras lúdicas do pessoal do Sítio primeiramente às paradidáticas: "como essa vovó saberia todas essas coisas? Desde quando Dona Benta é cientista?". Ainda que o leitor não se incomode acerca dos problemas de verossimilhança da coleção vista em conjunto, difícil crer que o procedimento passe despercebido.

Esse efeito de artificialidade, evidente, é o risco que Lobato corre para fazer valer um princípio que lhe é caro na aproximação com seus leitores-alvo, ou seja, as crianças. Dona Benta, personagem conhecida e amada, é próxima de todo o público, que a conhece e lhe tem afeto. O efeito é quase o mesmo das aulas que seus netos "escutam" nos livros: são explicações e conceitos passados não por uma distanciada figura de mestre reconhecido, mas pela calorosa e simpática avó, que, como dissemos, permite interrupções, repete até entenderem tudo, deixa questionarem. 
Portanto, escolher a avó é um risco consciente de artificialidade em prol de uma abordagem retórica mais próxima e eficiente. As crianças não ficarão de má vontade ao ouvir um "intruso" explicando as coisas, estando predispostas a ouvir "sua" querida avó. Mesma coisa com o Visconde de Sabugosa, outra personagem muito querida.

Uma das teses que defendemos com mais veemência, a escolha das personagens a veicular as ideias de Lobato é crucial para o autor. Talvez pareça simples aleatoriedade ao leitor contemporâneo, e talvez nem ao menos tenha sido uma escolha tão consciente da parte do escritor, mas são opções que fazem sentido e que possuem especificidades relevantes e servem a propósitos bem definidos. Se a personagem a veicular tal ou tal informação é estrangeiro, idoso, criança, conhecido ou "de fora", tudo isso importa e traz efeitos - até adversos, como a artificialidade que ora discutimos.

Acrescentamos, por fim, que essas operações não passavam totalmente despercebidas pelo público da época de Lobato. O jornalista Celestino Silveira, em comentário anexo a uma entrevista que fez com Lobato em 1944, comentou sobre as personagens, “divertidos uns, sentenciosos outros, sábios ainda outros, dos livros de 'seu' Lobato" (2009c: 177).

Ainda que sem intenção (aparente) de fazer um postulado acadêmico, Silveira comenta com singeleza o que estamos expondo. Podemos ver em suas palavras as conclusões a que chegamos: as diferentes vozes e dicções das personagens, as abordagens diversas e os efeitos que o uso de cada criatura produz.

Com relação aos paradidáticos, podemos aproveitar as características que a tripartição proposta por Silveira comporta: personagem divertida - Emília; personagem sentenciosa - Visconde; personagem sábia - Dona Benta. Três personagens queridas, que veiculam informações de acordo com suas naturezas específicas de personagens, gerando acolhimento, atenção e contribuição (na participação da leitura enquanto "parte" da turma das personagens) do leitor-mirim que Lobato deseja tocar.

A personagem divertida convencerá o leitor pela proximidade, a afetividade e o espírito de irreverência que caracteriza a infância questionadora de Lobato; a personagem sentenciosa tem a marca das leituras de livros, o conhecimento escrito, os conteúdos que são assimiláveis pelo estudo e esforço; a personagem sábia chefia o grupo, tem mais vivência na vida e na coordenação de conflitos, ensina e educa ao mesmo tempo, passa os saberes que são importantes para a formação do jovem bem instruído projetado nas tramas e aventuras da turma do Sítio do Picapau Amarelo. 


\subsection{COMPARATIVO ENTRE A RETÓRICA DAS PERSONAGENS ADULTAS E INFANTIS}

A personagem que se configura como a principal porta-voz de Lobato na sua obra infantil, e possivelmente a maior difusora dos credos lobatianos em toda sua literatura, é Emília, a reles boneca de pano que tornar-se-ia uma menina real nos últimos livros da série ambientada no Sítio do Picapau Amarelo.

Celestino Silveira cunhou o que podemos classificar como o papel de Emília na expressão das ideias lobatianas: "a voz da consciência" (2009c: 179). Por meio da irreverência da boneca/ex-boneca, o autor enfileirava postulados iconoclastas, críticos ou singelamente abusados, discordantes da moral da época, criando inclusive confrontos com as demais personagens: Emília muitas vezes é chamada de "torneirinha de asneiras" (as verdades lobatianas que não se calam), enxerida, pernóstica etc. Em boa medida, assemelham-se a xingamentos que o próprio Lobato colecionou para si no decorrer das décadas, ou uma maneira imaginosa de ressignificar como ele se via frente aos ataques que recebia. Um efeito reverso: quando Emília recebe ataques a sua independência de espírito e pensamento, esses valores se fazem notar mais fortemente e estabelecem-se como definitivos.

O próprio escritor reconhecia que ela era sua voz mais precisa, mais aguda e, num certo sentido, mais controladora, como podemos depreender desta pequena confissão em carta a Godofredo Rangel: "Quando escrevo um desses livros [do Sítio do Picapau Amarelo], ela me entra nos dois dedos que batem as teclas e diz o que quer, não o que eu quero" (2010a: 551).

Emília toma conta de sua bibliografia e fala do que quiser, do modo como acha acertado. Passa a ser verdadeiramente um alter ego de seu autor, que a usa de modo crescente para comunicar sobretudo suas insatisfações e inconformismos. Emília, dona de destinos e com oratória inflamada, definiria a si própria para seu criador: "E foi adquirindo uma tal independência que, não sei em que livro, quando lhe perguntam: 'Mas você que é, afinal de contas, Emília?'. Ela respondeu de queixinho empinado: 'Sou a Independência ou Morte!'. E é" (2010a: 551).

Podemos dizer que, guardadas as proporções relativas, Mister Slang é, no mundo adulto de Lobato, o que Emília é em seu mundo infantil: a iconoclastia, a inteligência sem amarras do convencionalismo, o porta-voz de seu autor para as coisas que o incomodam

ou afetam. É um procedimento recorrente no Lobato pós-1920 (quando ele passa a se 
dedicar as letras infantis, para nunca mais deixá-las): tratar dos "mesmos temas" em obras destinadas a públicos diferentes.

Um exemplo famoso é o caso das campanhas pela exploração do ferro e petróleo para fins desenvolvimentistas no Brasil, tanto em livros adultos como Ferro (1931) e $O$ escândalo do petróleo (1936) quanto em narrativas para pequenos leitores como História do mundo para as crianças (1933) e o verdadeiro manual de geologia infantil que é $O$ poço do Visconde (1937). Como se pode inferir pelas datas, o Lobato adulto e o Lobato infantil coexistiam em semelhantes ocasiões cronológicas e editoriais.

J. Roberto Whitaker Penteado pondera que "a literatura infantil pode exercer poderosa influência sobre as opiniões, atitudes e ações das pessoas adultas" e que "Lobato, tendo buscado influenciar a sociedade por diversos meios, sem sucesso ou com sucesso apenas limitado, deliberadamente escolheu os livros para crianças como veículo de transmissão persuasiva de sua ideologia, assim como dos valores que lhe eram caros" (2011: 297).

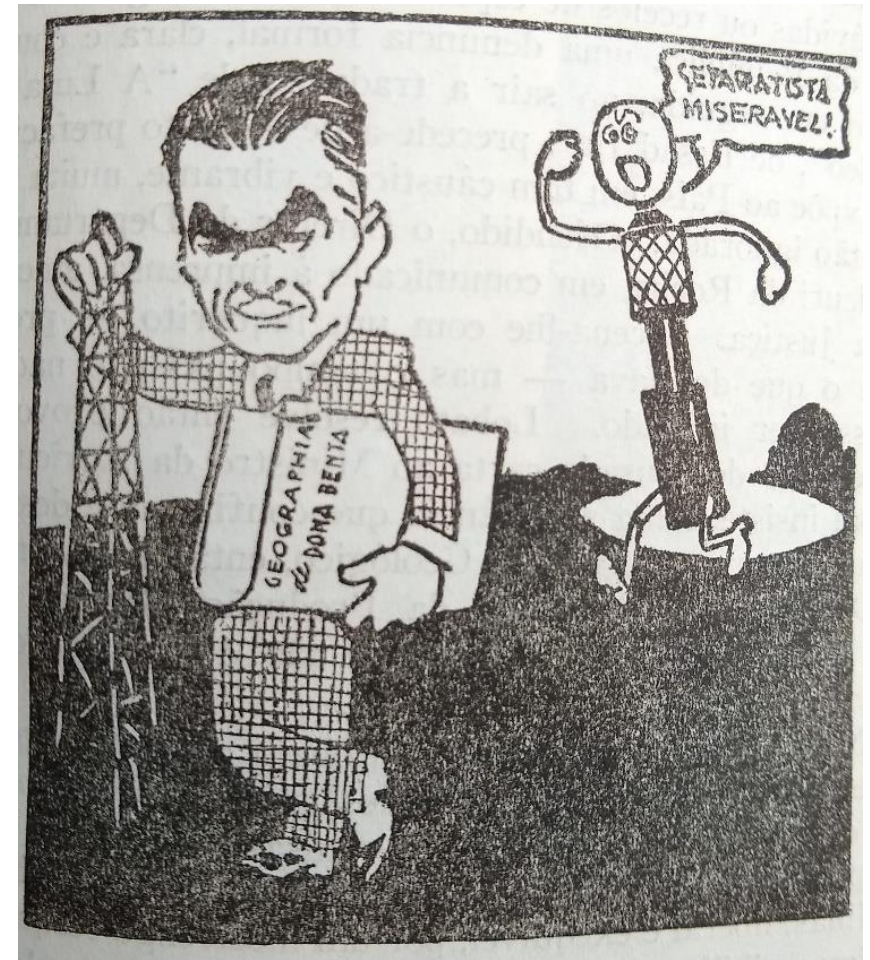

Figura 1: charge anônima (s/d). O pistão grita: "Separatista miseravel!". Trata-se de crítica aos métodos para explorar e comercializar petróleo propostos por Monteiro Lobato. Note-se que o volume que o escritor tem em mãos é Geografia de Dona Benta, uma obra infantil, e não O escândalo do petróleo. Os temas polêmicos aparecem nas duas "metades" de sua produção, e expressos de maneira por vezes equivalente. Fonte: Monteiro Lobato: vida e obra, de Edgard Cavalheiro (Companhia Editora Nacional, 1955, p. 417). 
Tal constatação autoriza a análise que ora desenvolvemos, isto é: o Lobato adulto e o infantil visam ao convencimento, à exposição, e muitas vezes dizem coisas assemelhadas ou até mesmo praticamente idênticas. Formas distintas de comunicar uma mesma ideia ou expressar um mesmo sentimento.

Então quais os pesos e tratamentos que as questões merecem nas duas "metades" da obra de Lobato? Em outras palavras, dizer a mesma coisa para adultos e para crianças implica efeitos de estilo, retórica e aproximação.

Observemos, a título ilustrativo, as diferentes posturas de Mister Slang e de Emília frente a "imperfeições" da natureza:

“- Vejo que Mister Slang faz muito pouco em nossa mentalidade murmurei ressentido.

— Não direi que faça pouco. Nem que faça muito. Vejo-a como vejo a goiaba no pé, admitindo que seria absurdo virem maçãs de uma goiabeira. A mentalidade por aqui é o fruto lógico de um hibridismo tríplice. Grão-de-bico, pacova e quimbombô só podem pensar os frutos que pensam..." (2008a: 21).

Mister Slang entende a ordem das coisas e olha com condescendência para o desarranjo das estruturas e procedimentos no Brasil, como se aqui fosse tentada constantemente uma inversão da lógica natural. E ironicamente associa aos hábitos alimentares do brasileiro (grão-de-bico, banana e quiabo) nosso atraso na conformação das evidências que deveriam nortear nosso progresso - ao ponto de parecer comparar as coisas que nunca mudam (os alimentos) à mentalidade que também não será alterada tão cedo, pois condicionada e estigmatizada ${ }^{61}$.

Vejamos um trecho de $A$ reforma da natureza em que Emília, deixada sozinha no sítio, se corresponde com uma amiga do Rio de Janeiro, apelidada Rã por sua magreza infantil, e conta a ela seus planos iniciais de mudanças:

\section{"Querida Rã:}

Estou só - só-só-ró-só-só! Todos foram para a Europa arrumar aqueles países mais amarrotados do que latas velhas e agora preciso que você venha passar uma temporada aqui. Você é das minhas: é das que não concordam. Podemos realizar aquele nosso plano de reforma da natureza. O Américo Pisca-Pisca era um bobo alegre ${ }^{62}$. Reformou a natureza como o nariz dele, e foi pena que a

\footnotetext{
${ }^{61}$ Essa visão, essencialmente determinista, se associa à ideia "prosopopeica" lobatiana, discutida em nosso capitulo 3, de um país que se enfraquece ao adotar medidas equivocadas, como se fosse um ente humano a se alimentar mal.

${ }^{62}$ Personagem constante em fábula do começo do mesmo livro, e que já havia aparecido em Fábulas, na história "O reformador do mundo" antepenúltima do volume. Trata-se de um homem que, observando que "a natureza só fazia tolices", imaginou um mundo em que, por exemplo, as grandes abóboras dessem em árvores e as pequenas jabuticabas crescessem próximas ao chão - o exato contrário do que se verifica. Após dormir e sonhar com o mundo reformado, acorda com uma jabuticaba que lhe cai no rosto; percebendo que morreria caso fosse uma abóbora que lhe tivesse caído de cima da árvore, passa a pregar que "fique tudo como está que está tudo muito bom" (1988i: 11-2).
} 
abóbora do sonho não lhe esmagasse a cabeça de verdade. Seria um bobo de menos no mundo. Nós faremos uma reforma muito melhor. Primeiro reformamos as coisas aqui do sítio. Se der certo, o mundo inteiro adotará as nossas reformas (...)" (1988i: 15-6).

Notemos como os temas de Lobato que comentamos nos capítulos anteriores se manifestam na fala da ex-boneca: a crítica à "amarrotada" Europa, o inconformismo solitário que exige mudanças e reformas, a falta de paciência com quem prega reformas "como o nariz" (isto é, tolas, superficiais, de araque, que não mudam as estruturas para valer), a visão progressista de que as melhorias tecnológicas e afins devem se espalhar para o mundo todo e estabelecer-se como padrões, realidades incontestáveis.

Emília, Mister Slang na infância, também reconhece estarem as coisas equivocadas, mas, inconformada e impetuosa, deseja mudá-las e adequá-las ao que acha correto. Não tem o olhar "de cima" do civilizado Mister Slang, porém reconhece que há incorreções e que elas podem ser reparadas. Mister Slang acredita numa tomada de consciência, uma mudança de atitude cívica, digamos; Emília quer mudar pela metafísica da mágica, pela transformação de estados, pela força.

Ambas as personagens, no entanto, representam um mesmo modelo lobatiano: o descontentamento de quem, pelo raciocínio, chegou à conclusão de que as coisas estão descompassadas e necessitam reajuste. A chave do Lobato adulto é pragmática e irônica, a do infantil, divertida e absurda; mas ambas são o mesmo Lobato que critica os usos e costumes brasileiros, políticos, humanos.

Mas não é só Emília quem representa a voz de Mister Slang nos livros infantis de Lobato. Dona Benta, já o dissemos, nas aventuras do sítio é a voz da sabedoria "paciente" de quem tem cultura e quer disseminá-la (como de resto era também o plano de Lobato e o intuito de Mister Slang), e faz as vezes do inglês quando é preciso instaurar uma "autoridade" a explicar conceitos científicos e comentar as transformações tecnológicas do mundo, por exemplo.

Um interessante levantamento de Whitaker - consultando leitores variados em uma metodologia precisa, descrita acuradamente em sua obra Os filhos de Lobato -, indagou também acerca dessas várias conotações pelas quais o conhecimento é filtrado e transmitido na obra infantil lobatiana. Sobre esse ponto, o pesquisador comenta que os testemunhos coletados "confirmam que as qualidades das personagens femininos se sobressaem, e identifica-se uma polarização entre duas presenças fortes: a de Dona Benta, que representa o poder do conhecimento, 'adulto', e a de Emília, a força da imaginação e da rebeldia" (2011: 281). 
Tais intuições coadunam com as visões que ora propomos. As personagens alcançam diferentes efeitos de afetividade - por se estabelecerem diferentemente no imaginário dos leitores - e convencimento, a depender do saber veiculado, da ocasião em que ele é transmitido e mesmo as características da transmissão. Um colóquio, uma aula e uma conversa são ocasiões diversas, com diversos efeitos e propostas, que Lobato manipula de acordo com a intenção da obra, a ideia que entende por bem explorar e a personagem envolvida na situação narrada.

Comparemos o que é dito a respeito do presidente americano Abraham Lincoln em América, pelo brasileiro e por Mister Slang, e em História do mundo para as crianças $^{63}$, por Pedrinho e Dona Benta:

“(...) Sentada em atitude de quem medita, a figura de Lincoln causa ao visitante impressão que jamais se apaga. Majestade, sem ser a dos reis - majestade da Razão, da Bondade, da Humanidade, da Retidão, da simplicidade de alma. Confesso que me senti como se houvesse ingerido qualquer alcaloide desses que transformam o equilíbrio normal das faculdades. Senti-me cocainizado... - Não o dizia eu? cochichou-me Mr. Slang ao ouvido, porque diante do semideus até a voz nos falha e só é possível conversa em tom de murmurio. Só aqui sentimos Lincoln e só aqui se torna compreensível a força com que esse homem, hoje puro simbolo, domina 120 milhões de criaturas. Para mim Lincoln é apenas o signo da Força Moral. Este monumento, menos ao homem que ele foi, ao Presidente, ao libertador dos escravos, homenagea em marmore a força das forças - a força Moral” (1951a: 35-6).

A admiração por Lincoln não só não arrefeceu como ganhou contornos hagiográficos:

“- Era então um homem de bem. Dos verdadeiros — observou o menino.

- Dos mais honestos que ainda existiram. Lincoln foi durante toda a vida um modelo de honradez em tudo, a ponto de ganhar o nome de o "Honesto Abe". Abe é abreviatura de Abraham. Estudou de rijo e tornou-se doutor em leis. Virou um advogado de muita fama, acabando eleito presidente do seu país. Foi no seu governo que rompeu a guerra civil. Lincoln, que odiava a guerra, teve de fazer a Guerra de Secessão toda - talvez a única no mundo que a gente possa justificar. E acabou vencendo os estados do Sul, os quais foram obrigados a ficar na federação e a libertar todos os escravos.

O prêmio que Lincoln teve foi morrer assassinado por um sulista louco. Mas nenhum homem no mundo é hoje mais venerado e honrado. Lincoln e Washington são os dois semideuses do povo norte-americano ${ }^{64 "}$ (2015b: 305).

\footnotetext{
${ }^{63}$ História do mundo para as crianças foi publicado originalmente em 1933, um ano após América. Não é justificado de modo algum, portanto, crer que as similitudes de discurso dos livros são coincidentais.

${ }^{64}$ Em A chave do tamanho, o Visconde conta a Emília uma história sobre "o velho Abe". Antes, "lembrouse do Presidente Lincoln, do qual ele havia herdado a cartola. Dona Benta era a maior admiradora desse homem. Dizia sempre: 'Depois de Jesus Cristo, o ente que eu mais venero é Abraão Lincoln"” (1988a: 149).
} 
Verifiquemos, por fim, um ponto debatido anteriormente, referente ao que Slang tem a dizer sobre a máquina (mecanização) em América e o que Dona Benta agrega em História das invenções:

“- Acho isso excessivo, Mr. Slang. A crise geral que já se acentua e vai ser tremenda, provem deste uso crescente da maquina. Ouço toda gente prever isso. (...) Ha uma evidente crise de trabalho. Nega isso, Mr. Slang?

- Sempre houve uma crise de trabalho, mais ou menos aguda. Quando se agrava, torna-se sensivel - e todos gritam que ha crise. Quando minora, todos proclamam que os tempos estão normais. Esse estado de crise permanente, ora mais, ora menos agudo, não passa dum logico efeito da lentidão da adaptação humana. O homem é lerdo e estupido. (...) Cada vez que aparece alguma nova maquina, ou nova invenção - e progredir é isso, maquinar, inventar - criam-se condições novas de vida, que provocam deslocações de homens. Quando apareceu o automóvel, milhares de cocheiros foram deslocados das suas boleias, milhares de tratadores de cavalos foram para o olho da rua. Crise? Deslocamento apenas. A maquina nova não veiu diminuir o trabalho, sim aumenta-lo, como os fatos o provam. Apenas criou trabalho novo. Surgiu a tarefa nova do chauffeur, e as dos reparadores de carros, lavadores, vendedores de gasolina e todo esse mundo da industria automotora. E aqui temos o ponto. Os cocheiros e mais homens postos á margem pelo auto foram em numero tremendamente inferior ao dos homens chamados a desempenhar as tarefas novas que o automobilismo criou" (1951a: 68-9).

A questão seria assim colocada por Dona Benta a seus netos, quase uma releitura ou complemento:

\footnotetext{
"Quando estavam construindo a primeira linha de tubos para a condução do petróleo, os inimigos da máquina enfureceram-se, destruíram a obra, alegando que aquilo vinha deixar sem emprego milhares de carregadores de petróleo. Não percebiam que aquilo vinha apenas libertar milhares de criaturas do trabalho penoso de carregar o petróleo com a força dos músculos. O fato de momentaneamente serem dispensados do serviço centenas de carregadores não tem a mínima importância para a humanidade; tem importância unicamente para os carregadores e só no momento, porque logo se arrumam em outros serviços.

O berreiro de hoje contra a máquina chega a ser grotesco; porque a máquina é a forma concreta do que chamamos progresso, e progresso quer dizer caminhar para a frente. Ora, como nada pára no mundo, como tudo marcha - e marchar é caminhar para frente e não para trás - havemos de ter cada vez mais máquinas. $\mathrm{E}$ os primeiros a se beneficiarem são justamente os que mais a condenam. Todos os artigos e livros contra a máquina são escritos em máquinas de escrever; compostos em linotipos, ou máquinas de compor; impressos em prelos, ou máquinas de imprimir; distribuídos por automóveis, ou máquinas de andar. O inimigo da máquina que se ele tem o lazer necessário para escrever contra a máquina é unicamente porque já existem milhares de máquinas a serviço do homem - cada uma das quais foi libertadora dum grande número de inimigos da máquina" (2017a: 77).
} 


\section{PANORÂMICA DA TRILOGIA AMERICANA LOBATIANA}

\subsection{A RETÓRICA DO CONVENCIMENTO E AS INSTÂNCIAS DA TRILOGIA AMERICANA}

A trilogia americana de Monteiro Lobato, mais que um conjunto restrito de livros próximos cronologicamente, guarda em si os germes de um pensamento que prima pela unidade de discurso e de intento. Isso não quer dizer que os três livros sejam idênticos no que expõem e pregam; como demonstrado, cada um aborda a problemática por um viés, com determinado método e alcançando efeitos específicos.

Não obstante, núcleos comuns permeiam as três obras. O elogio da organização americana, o desconsolo com o que está desregulado no Brasil, a vontade combativa de atacar as causas das mazelas e reformá-las. Ainda que sejam pontos de vista de uma pessoa - o autor dos livros -, o conteúdo verdadeiramente programático das obras demonstra empenho no sentido de instigar com fatos o público leitor.

Com o auxílio de personagens ficcionais, Lobato descortina sua visão de mundo e tenta propriamente convencer o leitor da viabilidade de suas ideias. Olivier Reboul, em sua Introdução à retórica, explana que "a primeira função da retórica decorre de sua definição: arte de persuadir” (2004: XVII). O escritor executará, dispondo de um arsenal de recursos estilístico-literários, um discurso que visa a persuadir seu público leitor, convencê-lo da utilidade de suas reflexões e a viabilidade de suas proposições. Uma legítima retórica do convencimento.

Expondo-se o que há de risível, ridículo, inadequado, desenvolvem-se táticas para persuadir os que já olhavam com desconfiança as estatísticas oficiais, os atos de governo e os resultados econômico-sociais alcançados pelo Brasil nas suas gestões públicas - e ao mesmo tempo cooptar para o lado dos inconformados quem não havia pensado naqueles problemas ou não havia “se dado conta”. Importante retornarmos a Reboul:

\footnotetext{
"Ora, para ser persuasivo, o orador deve antes compreender os que lhe fazem face, captar a força da retórica deles, bem como seus pontos fracos. Esse trabalho de interpretação é feito por todos de modo mais ou menos espontâneo. Até a criancinha mostra ser um excelente hermeneuta, por exemplo quando percebe que a ameaça dos pais é aterradora demais para ser executada, ou quando interpreta uma frase do adulto no sentido que lhe convém.

Para ser bom orador, não basta saber falar; é preciso saber também a quem se está falando, compreender o discurso do outro, seja esse discurso manifesto ou latente, detectar suas ciladas, sopesar a força de seus argumentos e sobretudo captar o não-dito" (2004: XIX).
} 
Conhecer o público a que se dirige é a forma mais eficiente de detectar seus pontos flexíveis, por onde pode ser cooptado ou convencido. Saber falar a diversos receptores, que decodificarão a informação de acordo com seus valores, crenças e atributos constitutivos.

A citação a "criancinha" vem a propósito: o público infantil também pode ser alcançado, em suas devidas chaves de compreensão e entendimento. Reboul fala de hermenêutica, isto é, interpretação. Para a recepção da mensagem ser direta, sua transmissão não pode ser enviesada.

Lembremos dos netos de Dona Benta a falarem que só quando ela explica conseguem entender os conteúdos. Dona Benta aqui é Lobato: para convencer, precisa antes de qualquer coisa ser assimilada. A assimilação se faz dispondo-se dos elementos textuais de maneira a franquear o acesso ao que se quer dizer, do modo como se diz. Nas palavras de Reboul, “é preciso saber também a quem se está falando, compreender o discurso do outro".

Digamos que, conhecendo o idioma de seu leitor, é franqueado ao escritor falar sua língua; e assim aproximá-lo de si e de suas ideias, atingindo o fim último da comunicação de ideias desta monta: o convencimento. A questão persuasiva atravessa toda a produção "americana" de Lobato e revela-se crucial ponto tanto da obra como das intenções do autor em produzi-la da maneira como a produziu, bem como suas formas de veiculação e elaboração sob diversos formatos: folhetim, romance, rememoração, narrativa infantil.

Considerando a tripartição de instâncias que propusemos na análise de $O$ presidente negro (capítulo 2), podemos definir outro ponto comum à trilogia, associandoas à experiência de Lobato naquela época. Pois $O$ presidente negro, escrito no Brasil e pouco antes de sua ida aos Estados Unidos, é em parte assemelhado à primeira instância, a imaginativa: um romance que envolve ficção científica, fantasia e previsões. Lobato conta do que ele acredita que pode acontecer nos Estados Unidos e no mundo, ainda que exagerada e ficcionalmente. Fala da industrialização, do avanço científico e outros fatores que lhe são caros e frequentes, mas numa chave lúdica, sonhadora.

Como vimos no exemplo de Ayrton Lobo e seu carro, a imaginação não é exatamente uma leitura absurdista; é o exagero de um plano, de um sonho ou cogitação. Relaciona-se a uma clara vontade, dentro e fora das estruturas ficcionais: Ayrton deseja subir socialmente e posicionar-se entre os que mandam e têm; Monteiro Lobato quer, com 
esse romance, projetar-se internacionalmente. Ambos os intuitos serão destinados ao fracasso.

O segundo livro da trilogia americana de Lobato, Mister Slang e o Brasil, relaciona-se à esfera da realidade, a intermediária, que mais entranhada está nas outras duas e gera consequências. É aí que vemos o que há de errado com o Brasil, principalmente econômica e politicamente, e temos noção do que se faz e fez de errado para as coisas não funcionarem, na visão de Mister Slang e Monteiro Lobato.

A realidade, tanto para a ficção quanto para seu autor, é uma plataforma indissociável do que se quer analisar, perceber e eventual ou idealmente mudar. Discriminando bem o entorno, o resto será compreensível. Por isso, imprescindível lucidez e objetividade na exposição dos fatos a que se aludem ou que se explanam.

O terceiro livro, América, é o associado à instância narrativa porque é nele que se descreve com abundância de detalhes uma experiência pessoal e empírica, praticamente despida de imaginação, concisa. Miss Jane relata o que viu no porviroscópio quando esse objeto existia, nada mais. Lobato perpassa suas experiências nos Estados Unidos e as elenca com certa frieza técnica, advinda de suas vivências e de fontes várias, como a leitura de jornais americanos ${ }^{65}$.

Sem embargo, é difícil negar que, como comentamos, as instâncias se misturam e se inter-relacionam frequentemente. Miss Jane relatando o que viu no porviroscópio e Lobato perpassando as experiências no país estrangeiro também não são tão exatamente objetivos quanto se acreditam ou desejariam. Imperioso atentar para uma especificidade dessas "memórias": Lobato não se coloca como personagem, ou narrador-personagem.

\subsection{O AVATAR LOBATIANO ADULTO, SEMELHANÇAS E ABORDAGENS}

O conjunto dos "trazedores de verdades" de Lobato nessa época apresenta muitas semelhanças. São avatares construídos via operações de distanciamento, operações que funcionam simultaneamente como um reforço na autoridade das personagens (e de seus discursos) e como uma representação mais ou menos fiel do pensamento de Lobato, a depender de seus propósitos.

Para começar, tanto Mister Slang como Miss Jane, já de seus nomes, manifestam a respeitosa distância de deferência devida a um estrangeiro ou figura de reputação. É

\footnotetext{
${ }^{65}$ Segundo levantamento feito por Milena Ribeiro Martins em “América: um país, homens e livros”, ensaio constante no volume Monteiro Lobato, livro a livro: obra adulta (2014).
} 
importante deter-se na questão de tratamento. Fossem Slang e Jane ou "Seu Slang" e "Dona Jane", a autoridade pensada para essas personagens, suas falas e métodos estaria diminuída de grande força evocativa. Apesar de eventualmente serem referidos por outras expressões, como "o inglês", no caso de Mister Slang, e os inúmeros termos românticos utilizados por Ayrton Lobo para citar Miss Jane, ambas as personagens são na virtual maioria das vezes referenciadas como Mister e Miss, pelo menos se seu nome ou sobrenome constar na frase.

Mister e Miss são formas de referência que demonstram por parte dos autores dos relatos - e, na estrutura maior dos textos, de Lobato - um distanciamento que implica um variado feixe de intentos, procedimentos e resultados. Analisemos alguns deles.

\subsubsection{PERDA DA COLOQUIALIDADE}

Diante de um mister, de uma miss ou de um Sir, um Dom ou congêneres, a relação se reveste de inescapável formalismo. As conversas atêm-se aos modos mais polidos, numa espécie de artificialização comportamental. Os narradores (o brasileiro anônimo e Ayrton Lobo), com algumas ressalvas, "sabem seu lugar", ou assim entendem sua posição, encolhendo-se diante da inferioridade social ou moral em que acreditam estar enquadrados, por suas falas e ações.

Enquanto seus interlocutores se comunicam com eles de maneira mais descontraída, chamando-os por termos como "meu amigo" e eventualmente um anódino "senhor", os narradores não são exitosos em ultrapassar a barreira de distanciamento social que os faz tratar com afetação Mister Slang e Miss Jane. Quiçá essa pusilanimidade agrade a ambos os expositores, fazendo-os elegerem os destinatários de seus discursos.

Nos três livros de que ora falamos, o tratamento protocolar das personagens que denunciam as verdades é a regra. Mesmo quando a amizade, o amor, o afeto e outros fatores aproximadores tendem a neutralizar a formalidade da etiqueta, os narradores retomam-na por sua idealizada descrição dos caracteres das pessoas que descrevem.

Vide a título de exemplo o exame confessional que Ayrton Lobo faz de seus sentimentos para com a gélida deferência com que Miss Jane o trata:

"Eu ardia, positivamente ardia, e traia o meu amor em todos os olhares e gestos;
mas a enigmatica jovem não dava ar de o perceber. No começo a admiti como
um puro espirito, uma Cassandra sem nervos nem sangue. Depois duvidei da
existencia de tais puros espíritos e passei a ver em miss Jane uma
"desentendida". Talvez que me julgasse muito inferior a si e adotasse 
semelhante atitude como o meio mais facil de guardar as distancias. Mas erame impossivel conciliar isso com a amizade que ela me demonstrava e sobretudo com o ter só a mim no mundo depois de perdido o pai. Se de fato me julgasse inferior ou indigno de sua pessoa, certo que já me teria afastado do castelo. Não havia duvida, miss Jane fazia-se de desentendida..." (1967: 264).

Pode-se verificar no excerto que o narrador se sente inferior diante do interlocutor esclarecido, detentor de um saber e um agir inalcançável, que o impressiona. Ainda que se considere verdadeiramente amigo da jovem, Ayrton enxerga na inconclusão da correspondência de seus arroubos sinais de que sua amiga o considera abaixo dela, por quaisquer razões, e parece conformar-se com isso, singelamente convicto de que Miss Jane "fazia-se de desentendida" acerca do assunto.

Ao confessar-se ardentemente apaixonado por essa "Cassandra sem nervos nem sangue", Ayrton faz de sua suposta (ou autoproclamada) inferioridade uma barreira para o pleno estabelecimento de relações entre ele e sua amada; contudo, demonstra certo orgulho ao considerar que a moça apenas tem a ele "no mundo depois de ter perdido o pai”. Não explicita nesse momento seus sentimentos à jovem: sem o necessário vínculo de cumplicidade, o rapaz "recolhe-se" - e recolhe seus arroubos não retribuídos.

Não possuindo a audácia de declarar-se, Ayrton possui em mente os cenários simultâneos do amor não correspondido, da amizade imprescindível e da necessidade da mútua convivência entre ele e Miss Jane. Ele precisa dela pois a ama, ainda que intua que ela o não respeite; ela precisa dele por não ter mais quem olhe por ela após a morte do pai. Nenhum pode abdicar do elo, e isso talvez arrefeça o nervosismo moral do narrador.

Ainda assim, a frieza da jovem, veiculada em sua expressão de "não dar o ar de perceber" a intensidade dos sentimentos de Ayrton, desnorteia o narrador, que, inferiorizado pelas próprias conclusões acerca dos intentos e motivações da jovem, aceita permanecer no canto (abaixo) que imagina seu e, inerte, retoma o formal tratamento de "miss Jane" para referir-se à inapelável moça.

Forçoso reconhecer que a intimidade não se dá de modo pleno em praticamente nenhum momento das obras. Há sempre uma distância entre as personagens, que nunca serão consideradas perfeitamente iguais, e receberão tratamento assimétrico por seus comportamentos, gerando os efeitos de desproporcionalidade que expomos.

\subsubsection{ASCENDÊNCIA ESTRANGEIRA}


Mister Slang é inglês, apesar de residir na Tijuca; Miss Jane, ainda que tenha nascido no Brasil, tem em seu histórico familiar outros sangues:

\begin{abstract}
"Aproveitei o ensejo para esclarecer-me a respeito do professor Benson. Soube que era descendente de um mineralogista norte-americano que um seculo antes viera ao Brasil estudar a composição de certa zona aurifera. Gostou da terra e nela se fixou, casando-se com a filha de um fazendeiro de S. Paulo.

- Desse consorcio, explicou miss Jane, só veio ao mundo meu pai, que cedo foi enviado á Europa, onde se dedicou a estudos cientificos. Lá se casou tarde e lá residiu por certo tempo. Veio depois tomar posse dos bens deixados pelo meu avô - e aqui nasci eu. Mas não me lembro de minha mãe. Morreu muito moça, aos 29 anos... Desde essa epoca estabeleceu-se meu pai neste recanto e consagrou-se integralmente á sua invenção. Passou o nosso mundo a resumirse neste laboratorio. Raras vezes vamos á cidade, pouco interesse, aliás, achando nós dois em seu tumulto" (1967: 171).
\end{abstract}

Miss Jane tem sangue americano e, aparentemente, europeu, dado que seu pai casou com uma residente europeia. Esse dado é inconclusivo, pois se o professor Benson se casou na Europa sem ser europeu não se pode inferir que sua esposa, que lá residia, tinha ascendência ou sangue europeu - ela poderia estar na mesma situação que ele, uma estrangeira em solo europeu. Miss Jane não expõe mais detalhes de sua genitora, nem Ayrton Lobo parece ter especial curiosidade nesse ponto, tendo seu foco de atenção voltado às personagens que conhecera pessoalmente: o professor Benson e sua filha.

É revelador observar como a porção brasileira da família Benson é um tanto menosprezada e como isso fala muito sobre as personagens, seus caracteres e, num âmbito maior, da abordagem de Lobato como escritor condutor de teorias sociais e políticas. A avó de Miss Jane, brasileira, era filha de um fazendeiro paulista. Os ecos da biografia lobatiana são evidentes: Lobato também era um fazendeiro paulista e boa parte de sua vida se deu nesse mundo interiorano; sua esposa, Purezinha (Maria Pureza de Castro Natividade), podia ser um modelo para a avô de Miss Jane.

No entanto, observemos como essa brasilidade é repudiada em certa medida pelas personagens do romance. Ayrton Lobo insua-se em muitas ocasiões desgostoso das coisas da sua terra - "A vida é complicada, existem leis, policia, embaraços de toda especie, burocracia e mil peias" (1967: 128) - e, talvez por ser ele o autor do "romance dentro do romance", os demais atores do drama não demonstram maior entusiasmo pelas terras brasileiras, exceto por metas pontuais, específicas.

O avô americano de Miss Jane, pai do professor Benson, veio ao Brasil "estudar a composição de certa zona aurífera", gostando do país e aqui decidindo ficar e estabelecer raízes, casando-se. O professor Benson, contudo, não manifesta o mesmo entusiasmo e, na primeira ocasião de ir à Europa, evade-se. Fica durante anos na Europa, 
desenvolvendo suas pesquisas, casa-se tardiamente (já na madureza), fica algum tempo por lá e só resolve voltar ao Brasil para tratar da herança do pai. A esposa do professor veio junto, não podendo ser conhecido se engravidou na viagem, na Europa ou no Brasil. O fato incontestável, pela recordação da personagem, é que Miss Jane nasceu em terras brasileiras.

A atual Constituição Federal brasileira estabelece Miss Jane como brasileira nata em seu artigo 12, inciso I: "São brasileiros natos os nascidos na República Federativa do Brasil, ainda que de pais estrangeiros, desde que não estejam a serviço do seu país". O Brasil adota o chamado jus soli, ou "direito do solo", que dispõe como critério para a estipulação da nacionalidade não a nacionalidade dos pais - como o fazem muitos países europeus, por exemplo; jus sanguinis, o "direito do sangue" -, mas o juridicamente provável fato de ter nascido em território brasileiro.

Como O presidente negro foi primordialmente publicado em 1926, a magna carta vigente ainda era a primeira constituição republicana, promulgada em 1891. Nela, o artigo 69 dispõe em seu parágrafo $1^{\circ}$ que "são cidadãos brasileiros os nascidos no Brasil, ainda que de pai estrangeiro, não residindo este a serviço de sua nação". Não há escapatória: Miss Jane, gostando ou não, é uma mulher brasileira, nata ou cidadã.

Segundo disposição atual da Embaixada e Consulados dos EUA no Brasil (2019), filhos de americanos também podem receber por transmissão cidadania americana. Miss Jane, fosse o pai americano, poderia ter, logo, dupla cidadania, americana e brasileira. Porém, tudo indica que seu pai nasceu em solo brasileiro. Sua mãe, filha de fazendeiro paulista, dificilmente não o é brasileira. Mas seu pai é americano, o que parece criar um imbróglio de regras do direito internacional: tendo o pai de Miss Jane dupla cidadania, americana e brasileira, essa circunstância seria comunicada a sua filha, mesmo o pai tendo nascido inquestionavelmente em solo brasileiro?

Para o estabelecimento da nacionalidade de Miss Jane, independe o local de nascimento de sua mãe, no entanto. A ambiguidade da procedência é, não obstante, um ponto em que se deter. O que ela representa no discurso do livro e da obra de Lobato?

Uma explicação razoável é que Miss Jane age aqui como uma espécie de "agente duplo": é brasileira, como os leitores que consumirão o livro aqui, vivencia os problemas daqui e os experimenta; também é de algum modo uma americana, ou tem essa procedência latente, e isso a autoriza a observar com apartamento os problemas do Brasil, suas causas e soluções - além de a equiparar em certa instância ao leitor americano, alvo 
declaradamente visado por Monteiro Lobato ao escrever o livro com planos de lançá-lo nos Estados Unidos.

\title{
5.2.3. ALUSÕES ONOMÁSTICAS
}

Num recurso algo inusitado em sua bibliografia, Lobato faz com que as personagens-avatar da trilogia americana apresentem nomes que contribuam para o dimensionamento dos problemas propostos pelo autor, ou ao menos dão novas facetas a um contexto que merece ser analisado com mais atenção.

Comecemos com o nome do recorrente avatar inglês lobatiano: Mister Slang. Slang usualmente traduz-se por "dialeto", "gíria”, “jargão". Vejamos o verbete correspondente no tradicional Cambridge Dictionary (tradução nossa):

\begin{abstract}
"Slang é vocabulário que é usado entre pessoas do mesmo grupo social e que se conhecem entre si. Slang é linguagem muito informal. [O vocábulo] Pode ofender pessoas se usado por outras pessoas ou fora de um grupo de pessoas que se conhecem. Normalmente usamos slang preferencialmente para falar, não para escrever. Slang normalmente se refere a palavras e significados específicos, mas pode incluir expressões e idiomas mais complexos" (2019).
\end{abstract}

Mister Slang haver estudado em Cambridge talvez não seja uma coincidência ${ }^{66}$, quem sabe um indício do que Lobato queria evocar com esse nome: a definição "cambridgeana" de slang. Consideremos suas especificidades: ainda que associada a informalidade, esse jargão se relaciona mais a um código de linguagem e mesmo postura, uma ação voluntária. Feito um código a que só os iniciados tivessem acesso. Uma maneira de compreender e expressar as coisas própria de quem as vê de outro modo. Parece definir à perfeição o método de Mister Slang (ou de Lobato).

Importante a observação que o dicionário faz sobre a possibilidade de o slang “ofender pessoas se usado por outras pessoas”. Entendemos que essa conotação igualmente se encaixa à perfeição na iconoclastia lobatiana, dizer as verdades sem se incomodar com seus efeitos - ou antes aguardando que seus efeitos modifiquem as águas paradas da opinião convencional. Já transcrevemos o famoso dito de Emília: "verdade pura, da dura". Portanto, dizer sem meias-medidas o que se quer provar ou mostrar. Não parece acidental Mister Slang ser um célebre aluno dessa escola argumentativa.

Ainda mais: usa o slang quem fala. Ora, Mister Slang, como o Ulisses homérico descrito por Buchard, "é o herói da palavra, da persuasão e da paciência” (2014: 51). Faz

\footnotetext{
${ }^{66}$ Rever em nosso item 3.1.1. os trechos da pequena biografia do inglês da Tijuca imaginada por Lobato.
} 
relativamente pouco: anda, joga xadrez, lê jornal, visita monumentos. Mas fala, fala abundantemente. O inglês da Tijuca é responsável por dialogar e alcançar seus objetivos (convencimento, superação do estado de inércia, esclarecimento) via oralidade, por discursos. Sabe que nem sempre será compreendido, por isso inunda suas exposições de exemplos e explicações detalhadas, e seu fim último pode ser visto como o de educar o brasileiro, os brasileiros, o Brasil.

Como Mister Slang, as criaturas de $O$ presidente negro não parecem servir-se do famoso princípio da "arbitrariedade do signo linguístico", cristalizado nos estudos de linguagem pelo trabalho de Ferdinand de Saussure. Diz o linguista que:

\footnotetext{
"O laço que une o significante ao significado é arbitrário ou então, visto que entendemos por signo o total resultante da associação de um significante com um significado, podemos dizer mais simplesmente: o signo linguístico é arbitrário.

Assim, a ideia de 'mar' não está ligada por relação alguma interior à sequência de sons $m$-a-r que lhe serve de significante; poderia ser representada igualmente bem por outra sequência, não importa qual; como prova, temos as diferenças entre as línguas e a própria existência de línguas diferentes: o significado da palavra francesa boeuf ('boi') tem por significante $b$-ö- $f$ de um lado da fronteira franco-germânica, e $o-k-s(O c h s)$ do outro.

O princípio da arbitrariedade do signo não é contestado por ninguém; às vezes, porém, é mais fácil descobrir uma verdade do que lhe assinalar o lugar que lhe cabe. O princípio enumerado domina toda a linguística da língua; suas consequências são inúmeras" (2014: 108).
}

Ou seja, a relação entre um vocábulo (significante) e seu significado não tem necessária vinculação, não sendo nem programada e nem motivada, genericamente.

No entanto, para fins artísticos, literários, políticos e afins, uma obra intensamente autoral como a de Lobato pode desrespeitar esse princípio ou subvertê-lo a seus fins. Assim, como analisamos, Mister Slang chama-se Slang porque o slang tem importantes implicações para a personagem e para os planos expressivos de Lobato na veiculação de suas ideias. Chama-se Mister Slang deliberadamente, como dificilmente poderia chamarse Antônio, José ou Luís sem com isso enfraquecer sua movimentação de avatar lobatiano.

Com relação a $O$ presidente negro, a situação se afigura ainda mais complexa. Sabemos dos planos do romancista para com esse livro específico, que deveria fundar uma nova etapa em sua carreira e internacionalizar seu nome. Daí um dimensionamento ainda mais rigoroso aos nomes de suas figuras ficcionais, que deveriam fazer carreira importante no exterior - e portanto ter nomes memoráveis, que ficassem marcados para o público e fossem facilmente reconhecíveis. 
Acenando aos leitores norte-americanos, os nomes das personagens do romance de Lobato dizem respeito a nomes, marcas e referências de obscura identificação para o leitor brasileiro contemporâneo (e quem sabe igualmente indecifráveis para os de então, na década de 1920), porém espontaneamente perceptíveis para o virtual consumidor americano de então. Apontam os pesquisadores de Monteiro Lobato: Furacão na Botocúndia que:

\begin{abstract}
"O Choque também pontua-se por um senso de humor cerebral extremamente refinado - por exemplo, utilizando nomes inspirados na vida real para seus personagens. Evelyn Astor, o professor Benson e todos os seis membros da Convenção da Raça Branca baseiam-se em personalidades da vida real. Astor e Benson referem-se respectivamente a Jean-Jacob Astor (1763-1848), mentor da Biblioteca Pública de Nova Iorque, e a um dos filhos do arcebispo de Canterbury, professor em Eton, tradicional escola inglesa. Os membros da Convenção remetem, entre outros, a George Abbot - arcebispo de Cantuária que trabalhou na redação da Bíblia do rei James I, a Perkins - inventor de uma máquina a vapor, ao socialista utópico inglês Robert Owen e a Calvin Coolidge, eleito presidente dos Estados Unidos em 1924 com a maior bancada que o partido republicano já obtivera" (1997: 217, 220).
\end{abstract}

Novamente, não pensamos serem acidentais as coincidências: Lobato fala muito de máquina a vapor e industrialização ${ }^{67}$, por exemplo; e sua admiração pelos prédios americanos, sobretudo bibliotecas, exibe-se inequivocamente patente em América, entre outros inúmeros casos.

Como Lobato não discorreu propriamente acerca das motivações para a onomástica de seus avatares, cabem apenas especulações, sem conclusões definitivas. Entendemos não serem sem propósito, contudo, os caracteres comuns à nomenclatura de seus porta-vozes ficcionais: nomes em inglês, de significação mais ampla que puramente a de um batismo arbitrário, e que comportam nesse sentido efeitos conotativos e de aprofundamento de intenções, desígnios e procedimentos do autor enquanto ficcionista e divulgador de ideias, efeitos que precisam ainda serem dissecados em oportuno trabalho específico.

\title{
5.2.4. DISTANCIAMENTO OBJETIVO
}

Para veicular suas "ideias americanas", Lobato concentra-se em criar alter egos de respeito e confiabilidade. Não é casual o fato de que seus pregadores, em seus livros não infantis, não são brasileiros propriamente ditos. Ainda que Mister Slang e Miss Jane

\footnotetext{
${ }^{67}$ Vide a compilação parcial sobre máquinas, progresso e civilização do nosso Anexo I.
} 
possuam elementos de brasilidade, como a localização, a ascendência e a residência, possuem um hibridismo internacional que os torna simultaneamente distanciados e capacitados a apontarem as mazelas brasileiras.

No espírito e no texto de Lobato, quando um Ayrton Lobo ou o brasileiro amigo de Mister Slang apontam nossas falhas, em suas conclusões precipitam-se ou equivocamse. Daí o fascínio que demonstram com o inglês e a jovem Benson. São criaturas sem a proximidade com a terra que contaminaria seus entendimentos com paixão "patriótica" ou pelo menos uma boa vontade advinda do orgulho nacionalista.

O próprio discurso em primeira pessoa dos narradores denota isso, como se de algum modo um habitante do país em questão tentasse a todo custo amenizar ou relativizar as críticas a seu ambiente. Falta a eles objetividade. Então não é apenas coincidência Lobato "buscar” em outros países ou continentes seus argutos observadores. Com julgamento crítico pensado, descrito e desenvolvido com pragmatismo, tem-se nítido contraste com as personagens narradoras das histórias e encontros.

Mister Slang ilustra essa dinâmica, de maneira a dirimir dúvidas do narrador brasileiro, em dado momento de América:

\footnotetext{
“- Basta, Mr. Slang, intervim ferido no meu amor proprio. Acho que está metendo a riso o meu querido país.

- Não, meu caro. Apenas estou dando o nosso ponto de vista. Que dirá o estrangeiro? perguntam vocês. Pois estou a responder como estrangeiro. O que o estrangeiro diz é isto que estou dizendo. Conta a coisa, não a comenta. Sorri. Os nossos seculos de civilização ensinaram-nos esse comentario sutil que diz tudo sem palavras - o sorriso. Sorrimos...” (1951a: 78).
}

Como aludido, Mister Slang não tem interesse em fazer comentários apaixonados. Por não ser daqui, nada o prende ao Brasil. Não tem que "defender" o país, e certamente não se fere em seu amor próprio, como o suscetível brasileiro que o acompanha na viagem. Proclama-se superior ao olhar com condescendência ("sorrimos") as coisas brasileiras, mas afiança que sua visão é objetiva, compartilhada pela comunidade estrangeira: não são comentários pessoais, apenas fruto de observação isenta, criteriosa ("conta a coisa, não a comenta").

O narrador brasileiro amigo de Mister Slang demonstra essa dupla condição: tanto na narração ("intervim ferido no meu amor próprio") quanto no que diz ao interlocutor imediato ("acho que está metendo a riso o meu querido país") é passional. Ou seja, tanto no comentário ao leitor quanto no que comunica ao parceiro inglês, o brasileiro está subjetivizando, por assim dizer, a análise. 
Daí a importância de um guia "imparcial” como Mister Slang, que percebe essa armadilha retórica e a comunica sem rodeios. Aos brasileiros, cabe aceitar a análise vinda de fora, em certa medida; pois será ela que, pragmaticamente, como um juiz se debruçando sobre o caso, fará o elogio do justo e a repreensão do injusto.

Lobato detalha em um dos artigos de Ferro sua teoria do distanciamento que acura a visão crítica:

\footnotetext{
"Se nos afastamos do quadro e, depois de um estudo comparativo de como se enriqueceram as nações que hoje lideram o mundo, observamos de longe o nosso caso sem que detalhes inuteis nos perturbem a visão, é inevitavel em nosso cerebro aquele famoso estalo que desasnou o padre Antonio Vieira em menino.

Fatal que assim seja. Como pode saber que forma, que altura a montanha tem, o caçador que se vê perdido num dos seus espigões, atrapalhado de cipós, fechado pela verdura circundante, com a preocupação da paca que precisa para o almoço? Esse mesmo homem tirado dali e posto á distância em que cipós, copas de arvores e pacas se confundem num só azul, terá, com o mesmo cerebro, ideias muito outras - desta vez determinadas pela imensa estrutura da montanha, que ele afinal vê, e não mais pelos méros acidentes da montanha, que ele unicamente via" (1951c: 249-50).
}

Podemos inferir que para Lobato o homem se mostra um "acumulador de experiências". Se à experiência da vivência se soma a experiência do distanciamento, terse-á acurada, imparcial e sóbria avaliação dos problemas só avistáveis a partir da “estrutura da montanha" e não dos "acidentes", pedaços de um todo que ele nota de perto, ou de dentro (do Brasil, digamos).

$\mathrm{Na}$ literatura de personagens de Lobato, o estrangeiro equipara-se ao observador estrutural e o ente brasileiro, ao reparador dos acidentes próximos. Sem a frieza da análise, aos brasileiros cabe a paixão de defender sua terra com a emoção do nativismo, valor usualmente menosprezado pelo escritor, emulando muitas vezes um discurso oficial amorfo, sem pragmatismo, eivado de atributos patrióticos que o autor questiona. Quase uma zombaria da mentalidade que poderia ser parafraseada por um chiste ao estilo de "só quem é desta terra pode falar mal dela - ainda que o crítico tenha razão".

Essa voz vinda de fora condiciona os principais pontos de controvérsia política e crítica aos fatos brasileiros na trilogia americana de Lobato. O escritor intenta, e o demonstra estilística e textualmente, construir uma visão vertical que desautoriza ou questiona o vulgar e acomodado - associados à visão horizontal, plana, das personagens (ou entes) brasileiros. Seus pontos de vista serão, assim, complementados, explicados ou puramente emendados pela visão "macro", englobante, dos estrangeiros com que lidam. 
Vejamos um excerto de Mister Slang e o Brasil, acerca do "parasitismo" na política brasileira:

“- Diga-me, Mister Slang, que remédio a sua experiência aconselha para esse mal?

Mister Slang sorriu com malícia.

- Por que mal? Acho até um bem. Na minha idade o homem se torna cético e passa a ver as coisas através de um prisma muito diverso do da mocidade. Eu hoje só quero o pitoresco. Olho tudo pelo prisma estético. Vejo paisagens humanas, nas quais o parasitismo figura como um elemento estético de muito valor. Se dependesse de mim, confesso que estimularia ainda mais o parasitismo brasileiro, para ver até que ponto podem os agrupamentos humanos comportá-lo. O parasitismo é a lei da humanidade. Uma criatura parasita outra...

O cinismo de Mister Slang horrorizou-me. O Brasil para aquele homem não passava de uma cobaia imensa...

- Mas se fosse na sua Inglaterra, que faria? — interpelei-o.

- Bom, o caso aí mudava. A Inglaterra é a Inglaterra e até dos ingleses céticos merece o sacrifício dum ponto de vista puramente de arte. Se fosse o caso na Inglaterra, e a mim incumbisse destruir o parasitismo, a primeira coisa que eu, como governo, faria era constatar a existência dele" (2008a: 93).

Como aludimos em nosso capítulo 3, Mister Slang, admirador de Mark Twain, acredita que o Brasil é, num certo sentido, uma imensa sátira de costumes. E confessa estar aqui just for the fun, como diriam os modernos americanos. O país se revela, a seus olhos, como uma terra onde as coisas devem dar errado. O inglês não se zanga, comove ou emociona pelo desmazelo da ordem vigente, pois olha tudo "pelo prisma estético".

À parte em um mundo que não é o seu, Mister Slang faz as vezes de observador distante, que só olha, constata e comenta. Não há paixão em seus julgamentos, independe para ele a sorte do país. É seu amigo brasileiro que se declara "horrorizado", vendo o inglês tratar seu país como "uma cobaia imensa", bicho de circo a diverti-lo por sua selvageria incontrolada.

Para demonstrar a distância da criatura lobatiana, quando indagado de sua pátria, a Inglaterra, Mister Slang deixa de fazer graça: agora aquilo lhe toca, diz respeito a um país que respeita e admira, e o "ponto de vista puramente de arte" (o estético, que se diverte com a bizarrice brasileira) é sacrificado por um viés mais pragmático, que implica necessariamente "constatar a existência" do parasitismo - o que, para ele, os governos brasileiros ignoram completamente!

O inglês da Tijuca atribui sua fleuma às serenas percepções filosóficas adquiridas com a idade. Distancia-se, assim, também etária e cronologicamente, insinuando-se que o narrador brasileiro seja mais jovem que a contraparte britânica. Lobato na época contava com pouco mais de quarenta anos, enquanto Mister Slang, já o referimos, nascera em 1872 e tinha aproximadamente cinquenta e quatro anos de idade. 


\subsubsection{O FASCÍNIO DOS ESTRANGEIROS}

Estritamente ligado ao que referimos anteriomente, imprescindível a Lobato criar figuras estrangeiras que se destacassem e demonstrassem, pela voz, postura e comandos, superioridade aos brasileiros. Assim se retrata, de guisa metonímica, o embate entre Brasil e mundo. Como tantos caricaturistas de então ${ }^{68}$, feito seu próprio ilustrador Belmonte, o escritor assim adequa situações políticas e sociais a definições constitutivas de personagens, o mesmo esquema dos cartuns em que países são representados por um de seus líderes ou uma sua celebridade:

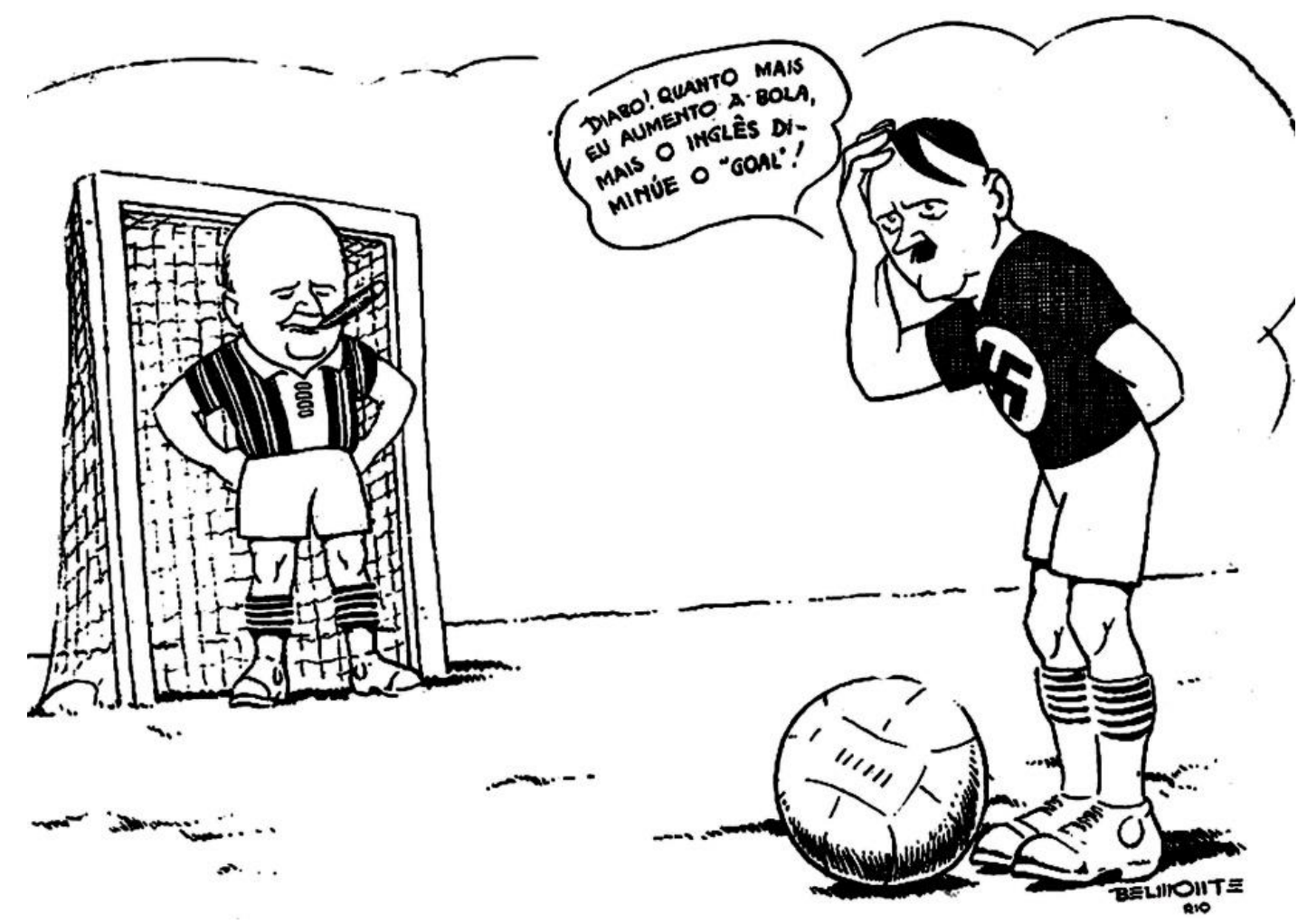

Figura 2: cartum de Belmonte (s/d). No balão: "Diabo! Quanto mais eu aumento a bola, mais o inglês diminúe o 'goal'!”. As personagens retratadas são Hitler e Churchill, no contexto da Segunda Guerra Mundial. Ambos aparecem uniformizados com motivos de seus partidos, o que é suficiente para que, junto a suas feições, sejam reconhecidos pelo leitor. Fonte da imagem: Abel Costa Caricaturas (2015).

Notemos que, de forma flagrante, os brasileiros dos três livros que comentamos são entes pálidos, ignorantes dos jogos e condicionamentos do planeta, estatizados numa

\footnotetext{
${ }^{68}$ Lobato, ele mesmo ilustrador e pintor ocasional durante praticamente toda a sua vida, dava muito valor à caricatura, contratando vários caricaturistas para ilustrarem seus livros. Em Ideias de Jeca Tatu, há um ensaio intitulado A caricatura no Brasil.
} 
ilusão de imobilismo de que só despertam parcialmente com o auxílio dos estrangeiros. Não é uma relação de colônia, mas de dependência cultural. Os brasileiros (ou o Brasil) têm os olhos fechados, estão acomodados. Ou sequer se dão conta das reais dimensões dos problemas.

Os estrangeiros, em contrapartida, são refinados, cultos, eruditos. Vivem bem (vide a casa do professor Benson), são viajados (Mister Slang), portam-se de maneira exemplar. Os arroubos de impaciência e inconformismo são todos dos brasileiros; os Bensons e Mister Slang analisam e descrevem friamente os temas, com precisão matemática. Observemos a diferença nos modos de encarar um problema entre o brasileiro e Mister Slang:

\begin{abstract}
“- Irra! — exclamei. — Não se pode fazer uma síntese mais rigorosa! O que me admira é que apesar disso o Brasil prospere.

Mister Slang sorriu com piedade e replicou suavemente:

- O Brasil não prospera, meu caro. Não pode prosperar. Chamam vocês aqui prosperidade a um claro fenômeno de gigantismo. Há deformação para o maior apenas. Inchaço. Entre Argentina e Estados Unidos, o Brasil dá-me a ideia duma lesma ensanduichada entre duas locomotivas. É que o Brasil se afez à sua miséria crônica, como o chim, e não vê, e não compara. O Brasil, perdoeme a sinceridade, é um pobre gigantão hebeté. Brinca com brinquedinhos de Nuremberg: - a sua "imensa riqueza", a sua "inteligência" etc., e já perdeu de todo a sensibilidade e o senso do real. Não é impunemente que se martiriza em camisola-de-força um pobre rapaz..." (2008a: 63).
\end{abstract}

Observemos como o brasileiro, emotivo, conclui logo que "não se pode fazer uma síntese" que seja precisa e acurada. Mister Slang ri com superioridade e traz seus recursos retórico-argumentativos: comparações com os países "que deram certo" (Argentina e Estados Unidos), a crítica administrativa (inchaço, deformação, gigantismo), a inutilidade de paliativos ("brinca com brinquedinhos") diante de problemas graves que exigem pronta ação.

Em América, o narrador brasileiro diz, logo ao abrir o livro:

\footnotetext{
"Anos atrás o bom deus Acaso pôs no meu caminho um homem de singular filosofia - o inglês da Tijuca. Suas ideias chocavam, aberrantes que eram das ideias e pontos de vista do monstro de mil corpos e uma só cabeça chamado Toda-Gente. Mr. Slang via com seus olhos azues e pensava com seu cerebro. Pensava em linha reta e via com nitidez: - daí o ser olhado de esguelha pelos que viam torto e pensavam com teias de aranha" (1951 a: 7).
}

A admiração pela figura quase mítica de Mister Slang faz o brasileiro hiperbolizar suas aptidões, colocando o inglês como um bastião da independência mental contra um monstro figurativizado na ideia de uma coletividade pensando igual e erradamente ("o monstro de mil corpos e uma só cabeça chamado Toda-Gente"). A descrição quase se 
assemelha um tipo de mito tradicional em certas culturas, referente ao estrangeiro que chega para elucidar, salvar, proteger uma comunidade. O encantamento beira $\mathrm{o}$ maravilhamento religioso.

\subsubsection{NEUTRALIDADE DO NARRADOR}

Ainda que não em termos absolutos, pode-se falar em uma neutralidade, ou um apagamento, do discurso dos narradores para apresentar as ideias das personagens estrangeiras. Os narradores (Ayrton Lobo e o brasileiro anônimo) servem-se das ferramentas textuais não para fazer valer suas ideias mas para expor com o máximo de rigor e exatidão as teorias de Mister Slang e a parelha pai e filha Benson. Seus apartes são circunstanciados para conferir maior clareza, precisão ou detalhamento ao que os teóricos estrangeiros explicam.

Vejamos um exemplo dessa “autoanulação argumentativa” em Mister Slang e o Brasil:

\footnotetext{
"Abri a boca.

— Como pode existir o que não existe, Mister Slang? Parece-me um contrasenso.

— Uma cosa brasileña apenas — explicou ele —, como há cosas de España.

- Trata-se de...

- De uma escola profissional, e de nome pomposo - "Escola de Aperfeiçoamento", que custa ao Tesouro 140 contos anuais, que tem diretor, professores, empregados etc. mas não tem casa, nem alunos.

- Como? É um absurdo!

— Existe só no orçamento, eis aí.

— Assombroso!...” (2008a: 91-2).
}

Os comentários do brasileiro apenas reforçam a intensidade das proposições ("é um absurdo", "assombroso") ou nem mesmo chegam a completar-se, por não possuir o narrador a informação ansiada ("trata-se de...”). A primeira frase do excerto demonstra que o papel do brasileiro nessa discussão resume-se a provocar as respostas de Mister Slang, que trará os fatos, os dados e mesmo guiará as reações de indignação, surpresa ou pasmo de seu amigo.

Patente, pois, como o brasileiro deve a Mister Slang a elucidação de suas dúvidas. É o inglês que, fleumaticamente, explana a situação do Brasil a seu ingênuo parceiro, que possivelmente não chegaria, sozinho, a essa conclusão. É um ponto de vista privilegiado, racional e penetrante, que aclara um problema que ao brasileiro parece insolúvel - e, como discutimos, as dúvidas do brasileiro são, por metonímia, as dúvidas do Brasil. O 
país não compreende seus deslizes porque não há um Mister Slang para lucidamente apontá-los.

Reitere-se, sem embargo, uma ressalva, importante para as considerações deste trabalho e para um dimensionamento mais acertado dos estudos lobatianos em perspectiva. Lobato não é apenas Mister Slang, mas também o brasileiro. Do mesmo modo, é Miss Jane, o professor Benson e Ayrton Lobo.

As operações e intenções que o levaram a edificar esses avatares levam-no a bipartir ou tripartir sua própria identidade de pensador social, analista político e autor ficcional. As dúvidas dos brasileiros já o inquietaram. Os problemas com que eles deparam já se lhes afiguraram insanáveis. As dúvidas, ironias e um orgulho deveras ferido de nacionalista magoado são evidentemente seus do mesmo modo. Ou foram, em uma etapa anterior à redação desses textos.

Tenha-se, assim, atenção especial a esse aspecto: Lobato também faz em alguma proporção seu mea culpa pelo atraso, pela incompreensão e pelo imediatismo míope que diz atrasar nosso progresso. Quiçá daí sua vontade de industrialização apressada, suas realizações pessoais para modernizar o parque gráfico brasileiro e as indústrias de extração do país, seus riscos pessoais em empreender aventuras monetárias, na bolsa, em petróleo, em siderurgia. Divagamos. 


\section{CONCLUSÃO: ANÁliSE CRítiCa dOS RESUltados dOS LiVROS "AMERICANOS"}

Ora tratemos propriamente dos "resultados" literários e extraliterários dos livros lobatianos abordados neste estudo, começando pelo que classificamos como sua trilogia americana.

O que se pode falar inicialmente é que nenhum dos três livros alcançou exatamente o sentido que Lobato desejava dar a eles. Seja pela recepção do público, pelo entendimento da crítica ou pelas próprias estruturas dos livros, a trilogia não alçou voos muito importantes, no geral. A situação dela neste 2019 é a de obra marginalizada na obra adulta do escritor, e nas décadas anteriores os leitores e as editoras não demonstraram maior interesse: antes da reedição pela Editora Globo no final dos anos 2000, nenhum dos três livros estava em catálogo.

Há muitas considerações a serem feitas. A principal delas talvez seja que a trilogia americana lobatiana ressente-se de certo "imediatismo", que poderia dizer algo aos homens da época de sua publicação, contudo décadas para frente apresentaria problemas de conteúdo e textualidade. A noção emergencial, mesmo assim, mostra-se cara a Lobato: são problemas que precisam de solução e devem ser discutidos ${ }^{69}$.

Apontamos em capítulos anteriores momentos em que Lobato expressa-se de maneira que hoje parece ineficaz: ingênuo no "transporte" simples de métodos dos Estados Unidos para o Brasil; louvador em excesso das figuras públicas que admira, que revestem-se de contornos hagiográficos e com isso perdem parte da dimensão humana e impossibilitam a crítica puramente racional; sonhador pouco prático, que crê que apenas com boa vontade e competência podem ser eliminadas as desigualdades, os atrasos endêmicos, o descalabro social e econômico das terras brasileiras.

Associado a esses equívocos, vem o texto em si. Todos os textos da trilogia apresentam problemas pontuais de desenvolvimento, que tornam a leitura algo "maculada", eivada de vícios estruturais. A seguir destrincharemos, em uma visão

\footnotetext{
${ }^{69}$ De algum modo, essa noção emergencial se apresenta em muitos momentos cruciais da bibliografia lobatiana. As histórias do Sítio do Picapau Amarelo, por exemplo, nascem em um projeto deveras explícito de "consertar" com presteza a situação dos livros infantis brasileiros, que precisavam de urgentes reparos em abordagens e conteúdos. Ficaram célebres as críticas de Lobato aos "embolorados" contos infantis, mal traduzidos e com moral ultrapassada, em obras como Reinações de Narizinho e O picapau amarelo, nas quais as personagens da Carochinha ("personificada" na forma de uma turrona barata) reclamam de suas utilizações nas histórias clássicas e chegam a fugir dos livros em que estavam confinadas...
} 
panorâmica, o que se pode entender da recepção dos três livros, seus equívocos e conquistas.

Em seguida, como um contraponto de êxito, avaliaremos o que logrou sua obra infantil, ao discutir os mesmos problemas, e demais condicionantes envolvidas, como recepção do público e perenidade artística.

Temos esse foco perspectivo como crucial no dimensionamento da obra de Lobato enquanto autor, seus propósitos e os pontos que perseguimos nesta dissertação.

\subsection{O PRESIDENTE NEGRO NO SÉCULO XXI}

O controverso teor racial de $O$ presidente negro destaca-se imediatamente, no romance e na recepção que ele teve ao longo das décadas, bem como seu estatuto contemporâneo, ainda hoje não sendo assunto pacífico nos estudos lobatianos. Na época, o romance não causou no Brasil tanto frisson por seus elementos raciais; entendemos que virtualmente se alinhavam com o pensamento reinante no país, inclusive por parte da intelectualidade. Segundo Carlos Minchillo:

\footnotetext{
"Esse gênero de ressalva ao tema do livro passou longe da primeira apreciação crítica que a obra recebeu na imprensa brasileira, o que pode ser muito revelador da situação do negro no Brasil pós-1888. Não espanta que fossem aceitas aqui com tranquilidade as medidas de profilaxia social que o romance apresenta. (...)

É notável na primeira recepção crítica do romance a naturalidade - senão o franco entusiasmo - com que se aceita o violento triunfo dos brancos [na trama do romance], naturalidade que, diga-se de passagem, está inscrita no próprio texto ficcional (...). Silveira Bueno (1927) é exceção ao se incomodar com a descaracterização voluntária devido aos procedimentos de alisamento de cabelo e de branqueamento de pele a que os negros do romance se lançam com satisfação. Chrysanthème (1927), representando a atitude mais comum entre os resenhistas, sugere ganho humano na maneira 'pacífica' como o negro foi eliminado" (2014: 193-4).
}

Por outro lado, os editores americanos contatados por Lobato manifestaram, segundo ele próprio, opinião diversa. Em alusão sarcástica à hipocrisia que condenou moralmente seu livro, o escritor diria em carta de setembro de 1927 a Godofredo Rangel: "Meu romance não encontra editor. Falhou a Tupy Company ${ }^{70}$. Acharam-no ofensivo à dignidade americana, visto admitir que depois de tantos séculos de progresso moral possa este povo, coletivamente, cometer a sangue-frio o belo crime que sugeri” (2010a: 523).

Ao que os pesquisadores de Furacão na Botocúndia acrescentam:

\footnotetext{
${ }^{70}$ Assim fora batizada a abortada editora que Lobato pretendia fundar nos Estados Unidos com seu romance.
} 


\begin{abstract}
"Tendo enviado os originais de $O$ choque vertidos para o inglês à agência literária Palmer, com sede em Hollywood, no final de 1927, Lobato recebe resposta do editor-chefe, William David Ball. Apesar de ter lido a história com 'interesse acima da média', devido ao material apresentado 'de forma divertida, indicando uma imaginação criativa e rica', Bell afirma:

'Infelizmente, porém, o enredo central é baseado em um assunto particularmente difícil de se abordar neste país, porque ele irá, certamente, acender o tipo mais amargo de sectarismo e, por esta razão, os editores são invariavelmente avessos à idéia de de apresentá-lo ao público leitor', explica, ressalvando que 'nem mesmo o fato do ocorrido estar localizado 300 anos no futuro iria amenizá-lo na cabeça dos leitores negros'.

Elogiando a habilidade de Lobato, detentor de 'agudo senso dramático e qualidades altamente imaginativas', Ball recomenda prosseguir os 'estudos de inglês e de redação criativa' e o aconselha 'a prestar especial atenção ao tipo de material que é extensivamente utilizado pelos editores americanos. Investigue minuciosamente o mercado, como o senhor procedeu com seu próprio trabalho, pois isto irá ajudá-lo imensamente na sua escolha de um tópico.

'Não considere este manuscrito, de forma alguma, como esforço desperdiçado. Mantenha-o arquivado e mais tarde, quando estiver apto a visualizar a idéia sob uma nova perspectiva, talvez seja possível que o senhor recupere muito do enredo, entrelaçando-o com algum outro problema ou temática"” (1997: 220/2).
\end{abstract}

Causa espécie os planos de Lobato falharem justamente no ponto em que se julgavam mais seguros: a pesquisa de público e de mercado. O editor não escreve uma carta furiosa e nem se escandaliza, propriamente, porém alega razões comerciais e mercadológicas para se abster da publicação.

O editor sugere que o romance seja "engavetado" por um tempo, para sofrer um processo natural de maturação em que Lobato apararia as arestas polêmicas e aproveitaria com sucesso a parte estrutural da imaginação e ficção científica. Como aludimos em nosso capítulo 2, contudo, o autor já gestava a ideia desse livro “à Wells” há pelo menos duas décadas - apesar de sua redação efetiva, segundo Edgard Cavalheiro, ter se dado em menos de três semanas: "Mal a remota possibilidade de um livro editado nos Estados Unidos lhe ocorre, põe-se a trabalhar a todo o vapor, e em vinte dias está o romance concluído" (1955: 339).

As razões são de crer, assim, que $O$ choque era, naquele momento, o que seu criador desejava efetivamente que fosse - e ressaltamos que, apesar de haver fixado título diferente, O presidente negro, na republicação décadas após nas Obras completas, Lobato não mexeu na redação do romance, permanecendo o texto como fora publicado em livro originariamente.

Valorizando os valores pitorescos e fantasiosos do romance, Ball não conseguiu amenizar a frustração no espírito do escritor. Como apontamos, Lobato acreditava poder 
aplicar "as mesmas fórmulas" no Brasil e nos Estados Unidos, e as diferenças na recepção do livro aqui e lá o perturbaram sobremaneira.

Dirce Waltrick do Amarante discorre acerca da recepção que desanimou Lobato:

“Admirador fervoroso de Henry Ford e do way of life americano, parece-me
que Lobato não quis perceber que os conflitos raciais no Brasil e nos Estados
Unidos eram distintos entre si. No Brasil, Lobato não teve dificuldade alguma
para publicar o seu romance, uma vez que, desde a abolição da escravatura, a
impressão que temos é a de que já cumprimos a nossa obrigação com a raça
negra, ao deixá-la 'vagar livremente pelo país' (...).
Nos Estados Unidos, apesar do sectarismo racial que persiste até hoje, o
romance futurista de Lobato foi considerado uma afronta aos cidadãos
americanos negros, uma vez que o país tinha, na época, consciência de estar
em dívida com eles (...).
No tocante ao pedido de alteração da trama do romance, solicitada pelo
potencial editor norte-americano, Lobato, já de volta ao Brasil, confessou que
nada mudaria no seu enredo, pois 'a América que lá pintei está absolutamente
de acordo com a América (Estados Unidos) que fui encontrar"” (2012: 49-51).

O que no Brasil foi aceito como normal, nos Estados Unidos considerou-se "ofensivo". Podemos vislumbrar no caso uma bizarra ilustração do que nos propomos, em certa medida, a analisar: as "mesmas ideias" encontram, em ouvidos e interlocutores diferentes, reações e recepções diferentes. O Lobato americano não interessou aos americanos.

Talvez não quisessem saber de suas visões algo lúdicas de turista fascinado; talvez, como Ball insinua, já houvessem superado a problemática racial sectarista e preferiam não voltar as atenções a uma história que, em essência, diz respeito a grupos de pessoas que não se misturam; ou, não se pode deixar de refletir, talvez a sensibilidade americana houvesse resolvido hipocritamente descartar de consideração sequer a reflexão acerca de suas chagas étnico-sociais - a reação ressentida de Lobato tende a apontar essa explicação.

Convém apontar que mesmo depois da morte de Lobato o livro ainda se encontra bastante indefinido quanto ao sentido classificatório complexo de sua discussão racial. Paulo Dantas, correspondente e futuro biógrafo "irreverente" de Lobato, diz, em sua polifônica obra Presença de Lobato, assumindo a voz do autor de $O$ presidente negro, que o livro foi escrito "em louvor à negritude" (1973: 24). Diz ainda, sobre o contato de Lobato com pessoas e personagens negras: "Daí, desde cedo, [eu] ter simpatizado com a raça negra, uma grande e sofrida raça. Até cheguei a idealizar, numa das minhas fantasias literárias, uma parábola com um presidente negro governando os Estados Unidos" (1973: 24). Para Dantas, que comenta um famoso pedaço do entrecho do romance em que são 
denunciados os malefícios dos brancos contra os negros, não há dúvidas: o livro é “favorável" aos negros.

Marisa Lajolo e Lilia Moritz Schwarcz, autoras de uma criativa biografia infantil de Lobato publicada em 2019, Reinações de Monteiro Lobato, seguem rumo discrepante. No texto igualmente contado "por Lobato", a assunção de culpa se dá nestes termos: “o romance podia provocar e alimentar preconceito, incentivar violência, defender valores e atitudes racistas. (...) Meu 'romance norte-americano' era mesmo descabido. Um desastre. Sobram motivos para ser polêmico" (2019: 44).

O presidente negro apresenta uma prosa um tanto desleixada, seja porque o relato é feito em primeira pessoa por um jovem não muito capacitado, seja porque o foco do escritor era pintar as cores futuristas do que imaginava os Estados Unidos do século XXIII. Seu narrador padece de uma fabulação limitada, repleta de adjetivações esdrúxulas e idealizações românticas. A prosa é truncada, parecendo bastante incrível que uma personagem tão adolescente seja de fato um adulto, e seu caráter frouxo, o exagero de seus rompantes e suas resoluções bruscas enfraquecem a narrativa e tornam-na desajeitada, disforme.

Daí parecer arbitrário Ayrton ser "agraciado" pelos “excelsos" Bensons, uma peripécia que torna a aventura forçada, esmaecida. Não possuindo em si qualquer grande virtude que se imponha (ao menos pelo que expõe ao leitor), as atenções que recebe de seus anfitriões afiguram-se estapafúrdias, deslocadas. Como uma jovem instruída e fascinante (como o narrador a pinta) feito Miss Jane pode apaixonar-se por alguém como Ayrton Lobo?

Lobato, que queria com esse livro impor-se no mercado americano, descuidou da forma da escrita em prol de um conteudismo que, em suas melhores obras, conjuga-se ao estilo. O resultado é uma de suas ficções menos coesas, com diálogos expositivos e sem naturalidade, que ao leitor da época não agradou mais que ao contemporâneo, tornandose assim curioso objeto - mais considerado por seus vieses "externos" (político, histórico etc.) que por seus elementos literários.

O livro falhou comercialmente. Além de não ter sido bem recebido pelos editores americanos sondados, o público brasileiro, para quem o livro não foi "planejado", não o acolheu com entusiasmo e logo passa a consumi-lo cada vez menos, sendo o volume esquecido em diversas ocasiões. Já desde as décadas até a morte de seu autor, e, "a despeito da pressão publicitária e da resposta predominantemente favorável da crítica, passaram-se dezenove anos antes que se lançasse uma segunda edição do livro no Brasil, 
caso excepcional na carreira do escritor e do tradutor Monteiro Lobato" (2014: 190). Não é demais relembrar que igualmente morrem ali seus planos de lançar-se internacionalmente. O epílogo de sua aventura futurista mostrou-se, portanto, um impedimento ao futuro de sua aventura como autor internacional.

Para completar, o teor racial do livro desagradou tanto às sensibilidades modernas que em 1967 tem-se sua última edição - antes de ser relançado em 2010 pela Editora Globo em uma nova e reorganizada coleção completa das obras lobatianas. Um livro "raro" na bibliografia de Lobato, em certo sentido, e não lido pelo amplo público que seu autor almejava, $O$ presidente negro era (e virtualmente ainda o é) procurado por sua importância no exame das mentalidades raciais da elite cultural brasileira no começo do século XX.

Curiosamente, como comentamos, em sua época de publicação o livro parece ter encontrado poucos críticos desse aspecto específico, o que vai ao encontro de sua pertinência como objeto de análise nesse campo. Carlos Minchillo faz a ressalva: "Nem mesmo na representação ficcional de medidas eugênicas Lobato era um caso excepcional. (...) Não é preciso insistir que Lobato, seus pares e grande parte da opinião pública também compartilhavam uma perspectiva bastante ambígua sobre as relações raciais" (2014: 194).

No entanto, pelos fatores que apontamos em nosso capítulo 2 e por outros além, O presidente negro tem uma pertinência extracontextual subjacente. Importante para os estudos lobatianos e também como um dos escassos espécimes de ficção científica brasileira no primeiro terço do século XX (segundo levantamento feito por Everton Lopes Batista para a 'Folha de S. Paulo' em 2019), o livro possui em sua trama refinada movimentação de planos narrativos, que estudamos detalhadamente ao falar das instâncias em que se desenvolvem.

Seu plano de fundo, com a questão racial e as tensões políticas dela decorrentes nos Estados Unidos do século XXIII, ainda que se revele ingênuo e incompleto com base no corpo de fontes científico-antropológicas que se amealhou desde então, trabalha com legitimidade a conturbada separação étnica das populações mundiais; o oportunismo político que visa a segregar povos e contrapor nações; o preconceito que, nascido de séculos de acidentada convivência entre cores de pele, tenderia mesmo a exponencialmente ser catastrófico em algum momento.

A previsão de Lobato, portanto, ainda que não fosse de todo acurada cientificamente, pois embasada em conceitos eugênicos e outros fatores que depois a 
ciência oficial desautorizou, mostra-se acurada literariamente, pois cria distensões catalisadoras das interações e reações das personagens.

Com o conhecimento que se tinha em sua época, com as leituras que fazia e no mundo em que estava inserido, Lobato revela-se mais habilidoso do que a princípio aparenta, e cria outro paradoxo bem ao gosto dele: se é o lado científico de $O$ presidente negro que envelheceu e foi rechaçado - sendo portanto seu lado "evidentemente" descartável - por que são os aspectos propriamente literários do romance, os mais bem definidos do livro (ainda que com as falhas de um estilo apressado, a que aludimos), os menos discutidos e referenciados da obra?

Os estudos lobatianos devem atentar-se, contudo, a uma nota oportuna: o fracasso comercial do livro em sua "cruzada mercadológica" para conquistar o mercado norteamericano pode ter desanimado ao escritor, mas não o demoveu de todo de seus planos para alçar-se a esse imenso público, como atesta o seguinte trecho de uma entrevista que Lobato concedeu a Silveira Peixoto, da Gazeta-Magazine, em fins da década de 1930 (portanto, depois de seu malogrado romance e de sua viagem aos Estados Unidos):

“-É verdade, Lobato, que vai para a Argentina?

- Creio que irei, sim. Uma casa editora de Buenos Aires vai editar todos os meus livros infantis. Essas edições irão atingir não só toda a América Latina como também os Estados Unidos...

- Serão em castelhano e em inglês?

- Só em castelhano. Mas o castelhano é a língua auxiliar do norte-americano. E, entrando lá os meus livros em espanhol, logo os terei em inglês" (2009c: 164).

Note-se que Lobato cita a Argentina, que, como aludimos em nosso capítulo 3, o escritor via como uma espécie de "Estados Unidos da América do Sul”.

Não se pode ter por casual essa escolha de lançar lá seus livros, portanto: a Argentina funcionaria aí como uma ponte, pois, como ele afirma, "o castelhano é a língua auxiliar do norte-americano": é a língua do México, que divide com o Canadá e os Estados Unidos a grande extensão da América do Norte, por exemplo; e é igualmente a língua de muitas comunidades hispânicas que estão geograficamente próximas à terra ianque, notadamente as Antilhas, conjunto de ilhas de onde saíram e saem constantemente grupos de pessoas em direção ao país norte-americano - inclusive Porto Rico, território 
não incorporado estadunidense, que a partir de 1917 garantiria a seus habitantes nascidos pós-1898 cidadania americana ${ }^{71}$.

Da mesma forma, não se pode ter por acidental o plano ser lançar os livros infantis, mais "palatáveis" e convencedores do que seu romance jamais o foi. Como discutimos em vários momentos neste trabalho, Lobato pulverizou em determinadas ocasiões seus comentários, críticas e visões em várias frontes textuais, e a literatura infantil mostrou-se como sua mais bem-acabada e persuasiva plataforma ideológica.

Desse pequeno excerto depreende-se que possivelmente Lobato queria falar à América com outros porta-vozes, fracassado o agente anterior: sai o presidente negro, entram Dona Benta e seus netos.

Ressalve-se que ainda há que se estudar aprofundadamente o impacto das letras lobatianas nas gerações de leitores infantis argentinos a partir dos anos 1940; contudo, localizam-se esparsos testemunhos do alcance das obras. José Guilherme Merquior relembra: "Quero dizer o que Monteiro Lobato foi para mim e para tantos brasileiros e, mesmo fora das nossas fronteiras, para tantas crianças não brasileiras. Eu conheço, por exemplo, crianças argentinas profundamente marcadas por Monteiro Lobato” (1983: 12).

\subsection{IMEDIATISMO E PERENIDADE EM MISTER SLANG E O BRASIL}

Mister Slang e o Brasil sofre obviamente de flagrante imediatismo na crítica das políticas e rumos brasileiros. Possuía um alcance maior, mais forte na época em que foi escrito e publicado, voluntariamente não se revestindo da perenidade de outros projetos literários de Monteiro Lobato. Quase como se ele desejasse, antes de tudo e talvez exclusivamente, convencer ao público de sua época, num documento de urgência e sem maiores preocupações de estilo.

Porque o estilo do livro é bastante simples, por vezes simplório. A estrutura é convencional e repetida à exaustão. São colóquios, como o autor afirma, e nesses colóquios não há grande espaço para invenção: segue-se o modelo de pergunta-resposta, como em filmes há o esquema dos planos-contraplanos. As personagens principais parecem fixadas em dois tipos excludentes de comportamento: o narrador brasileiro sabe pouco e indaga muito; Mister Slang sabe muito e conclui tudo.

\footnotetext{
71 Trata-se do Jones-Shafroth Act, assinado pelo presidente americano Woodrow Wilson. Para mais informações sobre a natureza jurídica, especificidades e efeitos do acordo, vide o verbete correspondente na Wikipedia norte-americana, citado em nossa bibliografia.
} 
Há pouca intersecção entre essas atitudes, e na maior parte das vezes as razões são puramente para o avanço das explicações. Formalmente, o livro tem o vício de constituirse na tentativa de "provar um ponto", o que faz a narrativa ser tímida, por vezes quase inexistente. Há descrição de ambientes, alguma narratividade; pouco, no entanto, escapa aos colóquios, que dominam a obra massivamente ${ }^{72}$.

Ainda assim, é de se notar que Lobato não se descarta do texto, nem nunca assim o pensou. Pouco depois de publicá-lo na mídia jornalística, compila-o em livro; e quando estabelece o plano de suas Obras Completas, em 1946, inclui o livro em volume que divide com Problema vital. Nota-se hoje que as obras completas deixaram considerável quantidade de textos lobatianos de fora, como volumes de cartas postumamente recolhidas e o livro de contos O macaco que se fez homem, pois, indica Cavalheiro, "Lobato distribuiu os trabalhos [contos] (...) entre 'Negrinha' e 'Cidades Mortas"” (1955: 281). Portanto, salvar Mister Slang e o Brasil pode ser um indicativo de que o próprio autor dava a essa obra um valor que ia além da comunicação instantânea e descartável.

Como analisamos em nosso capítulo dedicado à obra, existem nela consideráveis virtudes literárias, para além das informações sociais, econômicas e políticas. Cria uma personagem com suficiente complexidade dinâmica para aparecer em outro livro de Lobato - honra que dividiria apenas com Jeca Tatu e as personagens do sítio de Dona Benta. E é esse mesmo Mister Slang que se configura como um avatar, um porta-voz de ideias lobatianas daquele período, o que precedentemente explanamos.

A notar que Mister Slang, contudo, também tem sua "validade" expirada após os "anos americanos" de que tratamos. Não chega a aparecer em volumes posteriores a Mister Slang e o Brasil e América. Tampouco estabeleceu-se indelevelmente no imaginário dos leitores, como boa parte das criaturas lobatianas. Mister Slang, parafraseando a célebre frase revisionista de Jeca Tatu cunhada por Lobato - "Jeca não é assim, ele está assim" -, não é porta-voz do escritor, ele está porta-voz.

Naqueles anos pré-campanhas brasileiras (ferro, petróleo), finda a fase de contista best-seller, Mister Slang será a mediação entre o autor e seu público. Não é tarefa exígua, dado o tamanho da ambição de Lobato em apontar os males brasileiros e sugerir remédios e experimentar novas estratégias editoriais.

\footnotetext{
${ }^{72}$ Luís Hellmeister de Camargo apresenta visão contrária: "O diálogo é um gênero que se caracteriza pelo debate de ideias. Nesse sentido, 'provar um ponto' não pode ser considerado um vício ou defeito, é o objetivo do gênero. As descrições e alguma narratividade podem ser vistas como artifícios engenhosos para tornar leve o debate de questões que poderiam ser áridas" (depoimento na defesa de mestrado do autor do texto, 2019).
} 
A importância de Mister Slang, aliás, aprofunda-se ao percebermos que as narrativas em que aparece, de gênero híbrido e inclassificável, servem de ponte na bibliografia lobatiana entre dois momentos bastante capitais em sua produção literária: a ficção dos primeiros anos - dos contos a O presidente negro - e a literatura "militante" obras de chamamento cívico e denúncia das mazelas sociais brasileiras.

Compreende-se, assim, o estatuto misto das obras desse período, entre a ficção, o jornalismo, o relato e a crítica política. Mister Slang não tem papel pequeno e nem participação irrisória nesse quadro: é a personagem que, não sendo propriamente construída ficcionalmente e nem propriamente embasada na realidade, tem livre trânsito entre essas dimensões, o que Lobato discute de maneira sutil e com grande grau de sucesso estrutural, talvez o maior em sua prosa publicada até os anos em que se dedica mais particularmente à literatura infantil, a partir dos anos 1930.

A questão infantil, pertinente dizer, mostra-se um outro sentido desse mesmo problema. Mister Slang é para a literatura adulta ou geral lobatiana o mesmo que Emília, Dona Benta, Visconde de Sabugosa e afins são para a infantil: personagens recorrentes que atravessam camadas ficcionais e realistas, vivem aventuras inventadas mas dispõem de informações, aparato crítico e conclusões que dizem respeito ao mundo "verdadeiro", além dos livros.

Sabemos, por cartas pessoais e depoimentos de Lobato, que, além da movimentação pelos ambientes da ficção e realidade, suas personagens possuem o duplo estatuto de igualmente trazerem, sob forma ficcional, opiniões e postulados que, essencialmente, são os mesmos de seu autor. Daí a impossibilidade de desconsideração de Mister Slang e o Brasil, que não só apresenta digna estruturação para os fins propostos - de esclarecimento, exposição e convencimento do público - como demonstra penetrante camuflagem do espírito e ideias do próprio Lobato, escondidos sob a autoridade e a alegada neutralidade do inglês da Tijuca.

\section{3. "NOVA DOUTRINA MONROE” OU AMÉRICA PARA OS BRASILEIROS}

Se América nasceu de um compreensível desejo de "contar" os Estados Unidos, possui a justificativa extra de ser o capítulo final, o epílogo concludente, da aventura de Lobato na América do Norte. Depois de seu retorno do consulado, Lobato dedica-se a campanhas políticas explícitas no Brasil, o que lhe indispõe com o Estado Novo getulista e chega a lhe mandar para a prisão em pelo menos duas ocasiões, ambas em 1941. 
Os ecos de América são evidentes, pois Lobato vai se dedicar a propagandear Brasil afora, pelos meios oficiais (cartas abertas a políticos, por exemplo) e editorais e públicos (livros, artigos, conferências), o que viu nos Estados Unidos e julga de proveitosa aplicação e aproveitável utilização. Em inúmeros momentos de América o escritor dá a entender que os métodos desenvolvidos em terras americanas podem ser importados para o Brasil com sucesso, como de resto comentamos no terceiro capítulo.

Não se trata de coincidência Lobato haver publicado, no ano anterior à saída de América, o pequeno manifesto Ferro. Alojado no meio da trilogia americana, parece peça deslocada, à primeira vista; em verdade, antes pode ser enxergado como necessário complemento à visão que o autor desenvolve nos três livros de sua obra adulta que dissecamos neste trabalho. Ferro reúne artigos comentando métodos práticos para obtenção de um ferro de qualidade sem os problemas logísticos que entravavam, alegadamente, o desenvolvimento em larga escala de uma indústria siderúrgica/metalúrgica no Brasil ${ }^{73}$.

Lobato está, portanto, pregando, como Mister Slang, sobre o que viu e conhece bem, resultados que dependem apenas de boa vontade para serem alcançados por qualquer país: “demonstraremos que se até aqui não nos foi possivel reproduzir neste hemisferio o fenomeno norte-americano, está isso hoje ao nosso alcance, graças a ciencia e a tecnica norte-americanas" (1951a: 255).

O mais extenso volume da trilogia americana, e o único que nas Obras Completas organizadas pelo escritor localiza-se em um volume exclusivo, América editorialmente não se encontra entre os livros mais citados e conhecidos de Lobato, cujo público preferiu ao longo das décadas, grosso modo, as obras inequivocamente ficcionais.

Como já reportado, o estatuto dos dois livros em que Mister Slang aparece é híbrido; neste caso, situa-se entre o ficcional (personagens, diálogos e outras questões textuais puramente confeccionadas), o quase memorialístico (lembranças de viagem, descrições de lugares) e até o jornalístico-histórico (notícias, alusão a números e dados oficiais, síntese da crise de 1929).

A trilogia americana de Lobato parece em si conter o interessante germe do "experimentalismo interno": o que num livro funciona, aproveita-se no seguinte; o que

\footnotetext{
${ }^{73}$ Trata-se do "método Smith", assim chamado por causa de seu desenvolvedor, William H. Smith. Lobato conferiu pessoalmente a técnica quando esteve nos Estados Unidos: descartavam-se as custosas operações de refinamento do ferro sob altas temperaturas, em prol de um sistema de separação das impurezas minerais via imantação, com ótimos resultados.
} 
está equivocado, troca-se, modifica-se, altera-se. Desse modo, América aproveita os sucessos dos dois componentes anteriores do "grupo" e corrige seus equívocos, criando o que é possivelmente o mais estruturalmente complexo e inclassificável dos três livros.

A saber: aproveita de $O$ presidente negro o fascínio da futurologia, como se os Estados Unidos de então fossem o Brasil do futuro - o que espanta em certa medida ao próprio Lobato, que em carta a Godofredo Rangel diz que "o rush deste país rumo ao futuro é um fenômeno, Rangel! Quando escrevi $O$ choque, pus entre as maravilhas do futuro a televisão. Pois já é realidade. (...) O sonho que localizei em séculos futuros encontro realizado aqui" (2010a: 527) -, e a estruturação ficcional mais dinâmica, movimentada - não são apenas conversas, mas passeios e ambientes. De Mister Slang $e$ $o$ Brasil, apanha as personagens, adequadas ao tipo de argumentação que se quer viabilizar, e algo da estrutura tese (fala, do brasileiro) + antítese (crítica, de Mister Slang) = síntese (situação, o que "de fato" ocorre).

Naquele que discutivelmente se apresenta como o mais bem acabado literariamente dos livros da trilogia (não dispondo da imaturidade prosaica de $O$ presidente negro ou do esquema excessivamente rígido de Mister Slang e o Brasil), Lobato descreve os Estados Unidos enquanto simultaneamente faz crítica jornalística, literatura de ficção (com lances aristotélicos tais como uma cena de reconhecimento, logo ao início, que reúne as duas personagens básicas do texto), descrição histórica e análise de costumes.

Funciona num nível mais mediato que o outro livro de Mister Slang porque se universaliza ao sair do plano conjuntural brasileiro e adquirir uma feição de crônica como a que se popularizou no Brasil em meados do século $\mathrm{XX}$, versando sobre temas caros a ela: animais, relação homem e mulher, cinema. Em Mister Slang e o Brasil, falava-se de câmbio, moeda, importações. Há tudo isso em América; mas a dosagem é mais harmoniosa - Lobato, portanto, fez do livro anterior laboratório e dele usou o que funcionou e descartou o que lhe pareceu imprestável.

É nessa obra que aparece uma das frases mais citadas de Monteiro Lobato: "Um país se faz com homens e livros”. A frase abre o capítulo VI e demonstra o que comentamos em nosso capítulo acerca de $O$ presidente negro, isto é, a importância do livro enquanto objeto para o escritor. Isso vai ao encontro não apenas do pensamento alinhado com os ideais de linha de produção fordista como também ilumina aspectos da bibliografia e jornada lobatianas. 
Basta reparar que na primeira edição de América, por nós consultada no acervo da Biblioteca Monteiro Lobato, em São Paulo, há farta divulgação de fotos de prédios, arranha-céus e outros itens escolhidos deliberadamente para impressionar e entusiasmar o leitor brasileiro - que teria um intenso e fascinante choque ao dar-se conta da distância entre as realidades do progresso americano e brasileiro, contrapostas.

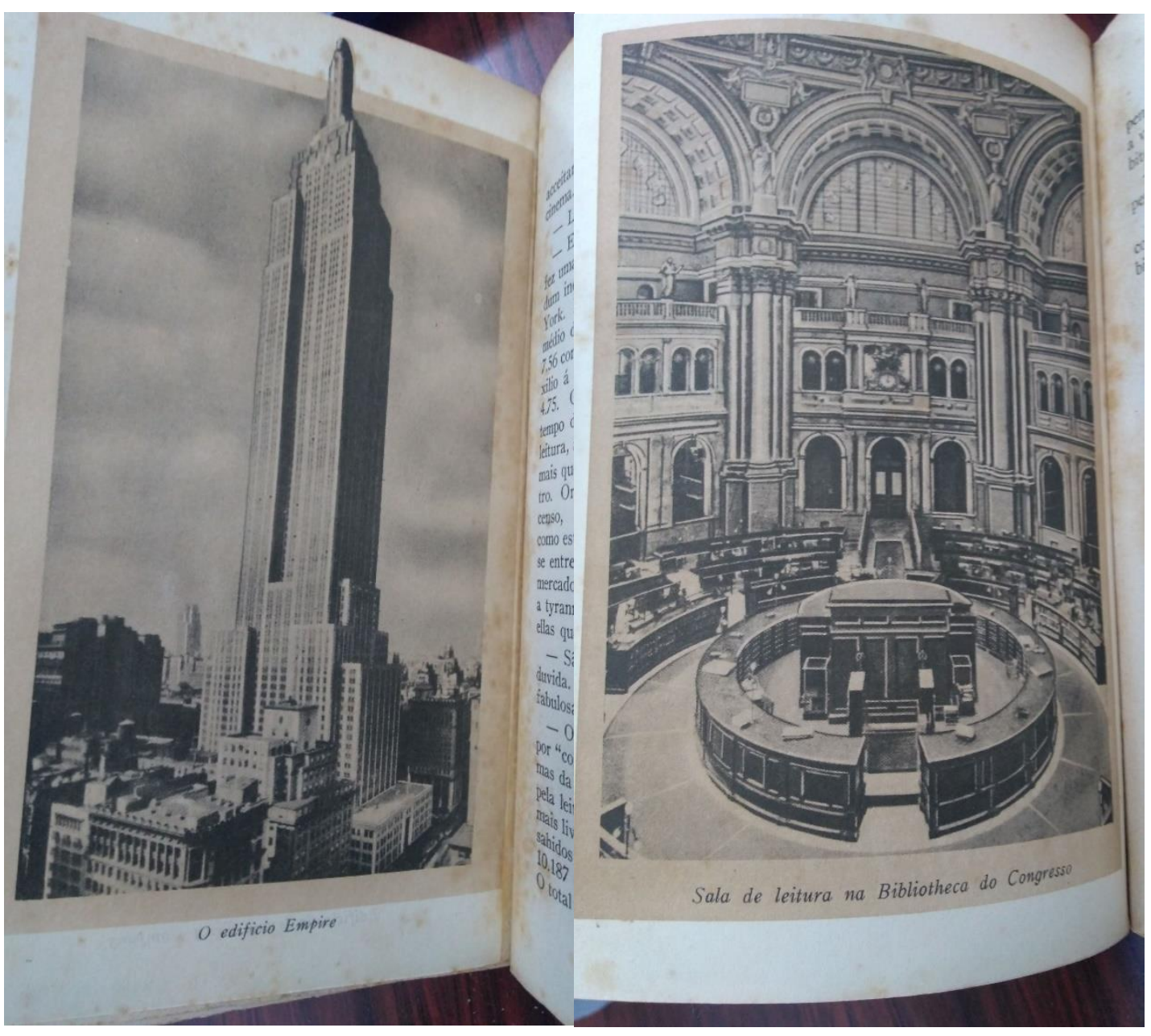

Figura 3 (esquerda): o Empire State Building. Figura 4 (direita): o salão de leitura da Biblioteca do Congresso. Fonte das imagens: primeira edição de América (Companhia Editora Nacional, 1932).

Note-se, a título de exemplo, as duas imagens acima, extraídas da referida edição. A primeira, o Empire State Building, habitualmente citado com admiração por Lobato ${ }^{74}$, demonstra visualmente, como meio de persuasão, a grandeza do edifício, retratado como um verdadeiro monumento. Há inclusive um efeito que faz o prédio "saltar" da página, numa ilusão de tridimensionalidade obviamente deliberada: como se a figura dissesse que

\footnotetext{
${ }^{74}$ Consultar, em nosso Anexo I, a categoria “Arranha-céus”.
} 
a grandiosidade se manifesta em tal proporção que nem cabe numa página tradicional de livro.

Semioticamente, apresenta intenções claras de convencimento e argumentação, como se o próprio Mister Slang a tivesse produzido: os prédios normais avolumam-se na metade inferior da fotografia, e quase toda a metade superior é ocupada apenas por espaços vazios, céus; e, evidentemente, o prédio gigantesco que o "arranhará", ganhando o espaço aéreo e fazendo prova do gigante empreendedorismo norte-americano.

A segunda imagem conjuga o amor pelos livros, cultura e conhecimento, ao alcance de todos, com a paixão pelo progresso, pela eficiência e praticidade, fatores muito caros em praticamente toda a carreira do escritor, demonstrando ainda uma vez a coesão do projeto autoral de Monteiro Lobato.

\subsection{UMA IDEIA QUE “DEU CERTO”: OS LIVROS INFANTIS}

Monteiro Lobato não escreveu um livro específico sobre os Estados Unidos para crianças, nem se encontrava entre seus planos futuros ou livros inconclusos qualquer menção sobre algo equiparado ${ }^{75}$. O escritor resolveu fazer diferente do que já havia produzido e em suas obras para o público jovem soltou "pílulas" sobre os Estados Unidos - comentando sua organização, fundação, política, cultura e avanço econômico em momentos aparentemente soltos de suas histórias: viagens, digressões, alusões.

Como comentamos, as discussões sobre o país ianque quase sempre se dão em um âmbito muito específico: os livros paradidáticos lobatianos. Também analisamos as características dessa escolha, suas abordagens e efeitos. Reiteremos que, em linhas gerais, os comentários nos livros paradidáticos propõem-se mais sérios, menos lúdicos, arraigados em dados e fatos, visando a um convencimento programático (e pragmático), equivalente ao que Lobato entendia que as crianças deveriam ter nas disciplinas escolares habituais, geografia, matemática e afins.

Quase como se Lobato acreditasse que deveria haver nova disciplina a ser estudada por seus leitores mirins, composta de noções de política, economia e sociedade dos povos. Uma instrumentalização teórico-factual que permitiria às pessoas abrirem os olhos e constatarem os problemas organizacionais de suas comunidades, os desarranjos

\footnotetext{
${ }^{75}$ Entre seus projetos inacabados ou em consideração quando de sua morte, constam uma versão para crianças do Orlando furioso de Ariosto e uma "história completa da América, desde o tempo em que isto foi um pedaço da Atlântida até agora” (2010a: 551), narrada pelo Aconcágua e encomendada por Emília!
} 
governamentais, as deficiências financeiras dos povos e possíveis mecanismos para dirimi-las.

Fanny Abramovich comenta que "ao ler uma história a criança também desenvolve todo um potencial crítico. A partir daí ela pode pensar, duvidar, se perguntar, questionar... Pode se sentir inquietada, cutucada, querendo saber mais e melhor ou percebendo que se pode mudar de opinião..." (1989: 143). Uma relação não passiva, portanto; o livro como uma fonte de questionamento, não de doutrinação.

O livro como um objeto manuseável que faz as vezes de portal para um conhecimento que indaga as motivações das coisas e as ações das pessoas, além de, pelo estilo, capturar as atenções e deleitar as horas de entretenimento de seus leitores. A ideia de Lobato, como a de muitos escritores infantis que lhe seguiram ou antecederam, consiste essencialmente em "abrir os olhos" dos pequenos leitores, como já havia tentado com os maiores.

Nesse sentido, Lobato é bem feliz com seus propósitos. Os livros paradidáticos, ainda que não se fixem no imaginário coletivo como os das aventuras lúdicas ${ }^{76}$, não eram desprezados pelo público e, como o indicamos, são muitas as correspondências que Lobato recebeu congratulando-o por ter explicado os conceitos e saberes escolares de maneira tão divertida e perspicaz, facilitando o aprendizado e a apreensão de conteúdos.

Encontramos, em nossas pesquisas efetuadas em 2017 nos arquivos das cartas originais recebidas por Lobato, casos que atestam a felicidade dos dispositivos empregados por Lobato para comunicar "a mesma coisa" em diferentes tons em sua obra adulta e infantil; em outras palavras, verificações empíricas de que às vezes Lobato conseguia seu intento de convencer e entusiasmar falando não aos adultos, mas às crianças. $\mathrm{Ou}$, arriscamos formular, falando as coisas adultas como coisas infantis ${ }^{77}$.

Vejamos o caso do correspondente Gilson Maurity Santos, leitor da obra para jovens lobatiana, que, após ler $O$ escândalo do petróleo e dessa leitura tirar pouquíssimo proveito e compreensão, finalmente entende a pertinência do manifesto ao tentar novamente empreender o feito anos depois:

\footnotetext{
"Mas o sitio do Picapau Amarelo continuou morando em meu coração. E como!

Reli inúmeras vezes todos os livros.E cada vez(não sei como conseguia fazer isso) abstinha-me de toda a ideia preconcebida e entrava no volume com a
}

\footnotetext{
${ }^{76} \mathrm{O}$ que podemos inferir com base na quantidade de edições dos volumes, as obras mais citadas e lembradas pelos leitores e os livros que mais foram adaptados para outras mídias, como a televisão e jogos eletrônicos. ${ }_{77}$ Nosso Anexo 3 traz parte substanciosa, transcrita com apuro e fidelidade, desse material.
} 
mesma delicia da prelibação duma historia do Monteiro Lobato.Tal qual da primeira vez.

Só um ano saiu um livro que me enganou - O ESCANDALO DO PETROLEO. -"Oh delicia! murmurava eu no bonde, apertando o livro contra o peito com os dois braços como se tivesse de protege-lo do mundo. A imaginação dava saltos,cambalhotas, a fantasiar quem de novo lá aparecia,que fariam os meus velhos amigos do sitio.Tive de fazer uma força enorme para não abrir o pacote ali mesmo no bonde. Consegui.Não abri.

Só em casa comecei a ler. Poucaas paginas bastaram para me mudar as ideias. - "Mas",disse comigo mesmo,"não faz mal. Estou ficando moço e preciso ler coisas serias.E, demais, o livro é do Lobato."

Devo dizer que as dez paginas seguintes me fizeram tropeçar e fechar o livro entristecido. Não compreendia nada.

Só mais tarde vim a le-lo todo,e com que entusiasmo e revolta! Mas isto não devia ser escrito".

Para um leitor acostumado à dicção de seus livros infantis, por vezes o que Lobato procurava comunicar não encontrava adequada interlocução. $\mathrm{O}$ leitor Gilson possivelmente teria mais facilidade com a versão infantil dos alertas sobre as campanhas de petróleo, os trustes internacionais, as sabotagens do governo que se encontram $O$ escândalo do petróleo: $O$ poço do visconde, na qual reencontraria seus "velhos amigos do sítio".

Ateste-se também que o método "publicitário" de Lobato, interligando livros e assuntos, prefaciando e traduzindo obras diversas, produzia notáveis resultados. O leitor Ary Moreira, em 1944, escreve ao escritor especificando o caminho que percorreu até encontrar $O$ escândalo do petróleo, que lhe esclareceu muitos pontos sobre o assunto que o fascinava:

\footnotetext{
"Prezado Snr:

(...) Estava eu no curso Ginasial, quando assistindo a uma aula de Geografia, o professor chamou-nos a atenção para um problema que já se tornou crônico, para nós brasileiros: o Petróleo. Com o espírito assim despertado, procurei obras que melhor me esclarecessem o assunto e foi assim, que lí e relí: "O Drama do Petróleo no Brasil" por Emílio de Maya e a "Luta pelo Petróleo" de Essad Bey, em tradução feita por V. Sa.

Neste último livro, as suas notas, tornaram-me inoculado pelo assunto, induzindo-me a ler "O Escândalo do Petróleo", obra que me trouxe ao conhecimento, de um modo irrefutável, a lazeira existente nesse setor da vida nacional".
}

Ao contrário da carta que anteriormente expusemos, Ary, sem dizer se era leitor da obra infantil de Lobato, afirma ter tido contato com o assunto do petróleo quando estava em sala de aula, no curso ginasial. Assim como com Dona Benta (e o próprio Lobato), um professor ou preceptor despertou curiosidade em uma jovem mente cívica.

O jovem continua: interessado, foi atrás, por seus próprios meios e pesquisas, de mais informações sobre o tema. Lendo a tradução de Lobato para A luta pelo petróleo, de Essad Bey, o leitor, "inoculado pelo assunto" que as notas de Lobato afloraram, decide, 
"induzido", ler $O$ escândalo do petróleo - a obra que, de todas que pesquisou, foi a que lhe "trouxe ao conhecimento, de um modo irrefutável, a lazeira existente nesse setor da vida nacional".

Queremos dizer que quando Lobato "acertava” a língua de seu receptor, com a dicção adulta, infantil, com a voz de suas personagens do Sítio do Picapau Amarelo, com seus artigos para jornal ou que meio fosse, a mensagem encontrava destinatário e ecoava, germinando frutos e inquietações. Citando nossas próprias palavras, sua retórica do convencimento empregava diversos sistemas e técnicas, com o fim primordial de persuadir, despertar atenção.

Em casos extremos, e para concluir esta dissertação, a ilustração mais significativa do alcance da oratória lobatiana pode muito bem ser este testemunho de Alice von Trexler, de 1945, que coletamos em nossas pesquisas. Trata-se de uma jovem "Emília" que, consternada pela ausência nas livrarias de $O$ escândalo do petróleo - livro outrora proibido pela censura do Estado Novo, o que talvez explique a desaparição -, entende por bem furtar de uma biblioteca o volume, auxiliada por um colega:

\begin{abstract}
"O último livro que li, de sua autoria, foi 'O escândalo do petróleo'.
Meu colega de escola, o primeiro da classe e talvêz do colégio todo, é um filho de japonês: Matinas. E, como eu, um fervoroso admirador seu; sempre mexemos na biblioteca desfalcada, lendo tudo. Um dia, encontramos seu livro, atráz de uns volumes de geografia, meio abandonado. Quíz lê-lo, mas meu colega, tomou o livro de mim. Queria ler primeiro, depois eu leria.

Ele leu e não falou nada durante algum tempo, mas quando começou, não parou mais. Estava revoltado com tanta hipocrisia, falsidade e imundície no governo. Esconder o petróleo! Fiquei mêses implorando para ler o livro e ele não m'o deu com a desculpa: 'Eu conheço você, Alice, e sei que vai ficar fora de si, qdo. ler. Eu conto alguma coisa'. Mas... água mole em pedra dura... Li o livro. Não sei nem explicar a sensação que eu tive. Fiquei bufando longo tempo e admiro a tenacidade sua, em tratar da busca do petróleo. Seu livro é admirável e pode crer, o objetivo que tinha ao escrevê-lo, foi plenamente alcançado em mim e em Matinas. Falamos longamente, com grande tristeza sobre o assunto. Nós o compreendemos perfeitamente, e com que gosto o ajudaríamos, se pudéssemos. Meu amigo, este ano, ingressa na faculdade de medicina, e eu que acabei o científico com ele, ganho a vida dando aulas particulares a alunos atrazados, porque o estudo superior no Brasil está fora do alcance da maioria dos estudantes. Nós não somos nada, pelo menos ainda não somos nada para poder ajudar homens de boa vontade como o senhor. Olhe, 'seu' Lobato, gente honesta, de bons propósitos, no meio de tanto cafageste rico e poderoso repimpado no governo é 'fosque apagado!'. Aquele seu livro, que encontramos na biblioteca semi-abandonada, não está mais lá... Figura na biblioteca de Matinas. Foi preciso furtá-lo, porque nas livrarias não está à venda. Pelo menos aqui não. Ninguem notou o roubo!"
\end{abstract}

Alice parece entender que assim o livro circularia ao menos entre alguns leitores, em vez de continuar menosprezado e escondido na biblioteca de origem. As ideias ali 
veiculadas podiam encontrar melhor recepção, em vez de permanecerem "fósforo apagado".

O livro como propagação de conhecimento, um produto valioso que deve ser consumido pelo maior número de pessoas possível; uma jovem garota indo contra a oficialidade (a escola, da qual furtou a obra, e as livrarias omissas, governos hipócritas e demais "cafajestes") e fazendo o que acredita ser certo (furtar) para convencer pessoas e tentar mudar o mundo com os "homens de boa vontade", sem se deixar vergar ou convencer, sem medo de falar o que pensa - excelentes imagens-símbolo que sintetizam o que Monteiro Lobato pregou, desenvolveu, e praticou em praticamente toda sua vida e obra. 


\section{BIBLIOGRAFIA CONSULTADA E REFERENCIADA}

ABRAMOVICH, Fanny. Literatura infantil: gostosuras e bobices. São Paulo: Editora Scipione, 1989.

AMARAL, Aracy. (Org.). Correspondência Mário de Andrade \& Tarsila do Amaral. São Paulo: Edusp; IEB, 2001.

AMARANTE, Dirce Waltrick do. As antenas do caracol: Notas sobre literatura infantojuvenil. São Paulo: Iluminuras, 2012.

ANDRADE, Mário de. O empalhador de passarinho. São Paulo: Livraria Martins Editora, 1971.

A lição do guru: cartas a Guilherme Figueiredo (1937-1945). Rio de Janeiro: Civilização Brasileira, 1989. Pauliceia desvairada. São Paulo: Nova Fronteira, 2013. Vida literária. São Paulo: Edusp, 1993.

ANÔNIMO. Livro das mil e uma noites. Tradução de Mamede Mustafa Jarouche. São Paulo: Biblioteca Azul, 2006.

ARISTÓTELES. Poética. Tradução de Paulo Pinheiro. São Paulo: 34, 2017.

ARRIGHI, Giovanni. O longo século XX: dinheiro, poder e as origens do nosso tempo. Rio de Janeiro; São Paulo: Contraponto; Editora Unesp, 1996.

ARRIGUCCI JÚNIOR, Davi. Outros achados e perdidos. São Paulo: Companhia das Letras, 1999.

ASSUNÇÃO, Moacir. São Paulo deve ser destruída: a história do bombardeio à capital na revolta de 1924. Rio de Janeiro: Record, 2015.

ATHANÁZIO, Enéas. 3 dimensões de Lobato. São Paulo: Editora do Escritor, 1975. AVATAR. Aulete Digital, 16 nov. 2019. Disponível em: < http://www.aulete.com.br/avatar>. Acesso em: 16 nov. 2019. AZEVEDO, Carmen Lucia de; CAMARGOS, Marcia; SACCHETTA, Vladimir. Monteiro Lobato: Furacão na Botocúndia. São Paulo: Editora Senac, 1997.

BAL, Mieke. Teoría de la narrativa (Una introducción a la Narratología). Madrid: Ediciones Cátedra, S. A. 1990.

BATISTA, Everton Lopes. Autores clássicos como Machado de Assis também escreveram ficção científica. Folha de S. Paulo, São Paulo, ano 98, nº 32.805, 25 jan. 2009. Disponível em: <https://www1.folha.uol.com.br/ilustrada/2019/01/autores- 
classicos-como-machado-de-assis-tambem-escreveram-ficcao-cientifica.shtml>. Acesso em 26 mai. 2019.

BÍBLIA. Português. Bíblia de Jerusalém. Nova edição, revista e ampliada. Edição Ecumênica. São Paulo: Paulus, 2016.

BIGNOTTO, Cilza Carla. Figuras de autor, figuras de editor. São Paulo: Editora Unesp, 2018.

BOOTH, Wayne C. A retórica da ficção. Tradução de Maria Teresa H. Guerreiro. Lisboa: Arcádia, 1990.

BOSI, Alfredo. História concisa da literatura brasileira. São Paulo: Cultrix, 1975.

BOTTMAN, Denise. Traduções de Monteiro Lobato, 2011. Disponível em: <http://naogostodeplagio.blogspot.com.br/2011/01/traducoes-de-monteiro-lobato.html>. Acesso em 27 mai. 2018.

BOTTMAN, Denise; KARAM, Sérgio. A Biblioteca do Leitor Moderno, 2018. BOURDIEU, Pierre. A ilusão biográfica. In: AMADO, Janaína e FERREIRA, Marieta de Moraes. Usos e abusos da história oral. Rio de Janeiro: Editora FGV, 2006.

BOURDIEU, Pierre. Razões práticas: sobre a teoria da ação. Tradução de Mariza Corrêa. Campinas: Papirus, 1997.

BRASIL. Constituição (1988). Constituição da República Federativa do Brasil, 2019.

Disponível em: <http://www.planalto.gov.br/ccivil_03/constituicao/constituicao.htm>. Acesso em 26 mai. 2019.

BRASIL, Pe. Sales. A literatura infantil de Monteiro Lobato ou comunismo para crianças. São Paulo: Edições Paulinas, 1935.

BUCHARD, ALAN BARBOSA. A morte em Homero: entre a escolha de Aquiles e a resistência de Ulisses. Trabalho de Conclusão de Curso (Graduação em Filosofia) Universidade Federal Fluminense, 2014. Disponível em:

$<$ http://www.helenismo.uff.br/sites/default/files/TCC-Alan.doc\#overlaycontext=node/13\%3Fq\%3Dnode/13>. Acesso em 6 jan. 2019.

CAMARGO, Luís Hellmeister de. Defesa de mestrado de Filipe Augusto Chamy Amorim Ferreira. São Paulo: Instituto de Estudos Brasileiros (IEB - USP), 10/10/2019.

CAMPOS, André Luiz Vieira de. A república do Picapau Amarelo. São Paulo: Martins Fontes, 1986.

CANDIDO, Antonio. A personagem do romance. In: A personagem de ficção. São Paulo: Perspectiva, 1974. 
CARTER, Rosemary Paula Leite. Monteiro Lobato acontece na América: análise de duas transposições do conto O engraçado arrependido. Tese (Doutorado) - Universidade Presbiteriana Mackenzie, 2012. Disponível em:

<http://tede.mackenzie.br/jspui/handle/tede/2334>. Acesso em 24 nov. 2019.

CASSAL, Sueli Tomazini Barros. Amigos escritos: correspondência literária entre Monteiro Lobato e Godofredo Rangel. São Paulo: Imprensa Oficial do Estado, 2002.

CAVALHEIRO, Edgard. Monteiro Lobato: vida e obra. São Paulo: Companhia Editora Nacional, 1955.

CECCANTINI, João Luís; MARTHA, Alice Áurea Penteado. (Org.). Monteiro Lobato e o leitor de hoje. São Paulo: Cultura Acadêmica, 2008.

CHIARELLI, Tadeu. Tropical, de Anita Malfatti: reorientando uma velha questão. Novos Estudos, São Paulo: Centro Brasileiro de Análise e Planejamento, v. 27, $\mathrm{n}^{\circ} 80$, pp. 63-72, 2008.

Um Jeca nos vernissages. São Paulo: Edusp, 1996.

COELHO, Nelly Novaes. Literatura infantil: teoria, análise, didática. São Paulo: Moderna, 2000.

Dicionário crítico da literatura infantil e juvenil brasileira. São Paulo: Companhia Editora Nacional, 2006.

COMEDIANS in cars getting coffee: At what point am I out from under?. Produção de Jerry Seinfeld. California: Crackle, 2017. 16 min, son, color. Episódio da nona temporada da série exibida pelo Netflix. Acesso em 12 fev. 2018.

COSTA, Abel. Caricatura: $O$ Desenho de Humor. Disponível em: $<$ http://caricaturasabelcosta.blogspot.com.br/2015/07/caricatura-o-desenho-dehumor.html>. Acesso em 16 jan. 2018.

DANTAS, Paulo. Presença de Lobato. São Paulo: Editora do Escritor, 1973. (Org.). Vozes do tempo de Lobato. São Paulo: Traço, 1982.

DOYLE, Arthur Conan. Sherlock Holmes: the complete stories. London: Wordsworth Editions, 2008.

DUARTE, Lia Cupertino. Lobato humorista: A construção do humor nas obras infantis de Monteiro Lobato. São Paulo: Editora Unesp, 2006.

EDREIRA, Marco Antonio Branco. Monteiro Lobato e seus leitores: livros para ensinar, livros para aprender. Revista brasileira de história da educação, Paraná: Universidade Estadual de Maringá, $\mathrm{n}^{\circ}$ 7, pp. 9-41, 2004. Disponível em: 
<http://eduem.uem.br/ojs/index.php/rbhe/article/viewFile/38669/20198>. Acesso em 13 jun. 2019.

FORD, Henry. Hoje e amanhã. Tradução de Monteiro Lobato. In: Os princípios da prosperidade. Rio de Janeiro: Freitas Bastos, 2012a.

Minha filosofia da indústria. Tradução de Monteiro Lobato. In: Os princípios da prosperidade. Rio de Janeiro: Freitas Bastos, 2012b.

Minha vida e minha obra. Tradução de Monteiro Lobato. In: Os princípios da prosperidade. Rio de Janeiro: Freitas Bastos, 2012c.

FRÓES, André Gilberto da Silva. Do urupê de pau podre à mecanização: Monteiro Lobato e a formação nacional (1924-1941). São Paulo, 2014. Dissertação (Mestrado em Culturas e Identidades Nacionais) - Instituto de Estudos Brasileiros da Universidade de São Paulo.

FRYE, Northrop. Anatomia da crítica: quatro ensaios. Tradução de Marcus de Martini. São Paulo: É Realizações, 2014.

GENETTE, Gérard. Discurso da narrativa. Belo Horizonte: Vega, 1995.

HEY, Vanessa de Paula. A literatura norte-americana na América de Monteiro Lobato. In: XX SEMANA DE LETRAS, Universidade Federal do Paraná (UFPR), 2018. Disponível em:

<http://www.humanas.ufpr.br/portal/eventos/semanadeletras/trabalhos/semana_de_letra s.docx>. Acesso em: 27 jul. 2018.

HALLEWELL, Laurence. O livro no Brasil. Tradução de Lólio Lourenço de Oliveira, Geraldo Gerson de Souza e Maria da Penha Villalobos. São Paulo: Edusp, 2012.

HILLYER, V. M. Pequena história do mundo para crianças. Tradução e adaptação de Godofredo Rangel. São Paulo: Companhia Editora Nacional, 1967.

HOBSBAWM, Eric J. Da revolução industrial inglesa ao imperialismo. Tradução de Donaldson Magalhães Garschagen. Rio de Janeiro: Forense, 2011.

Tempos fraturados: cultura e sociedade no século XX. Tradução de Berilo Vargas. São Paulo: Companhia das Letras, 2013.

The age of extremes: a history of the world, 1914-1991. New York: Vintage Books, 1996.

HOLANDA, Sérgio Buarque de. Raízes do Brasil. São Paulo: Companhia das Letras, 2015.

JATOBÁ, Roniwalter. O jovem Monteiro Lobato. São Paulo: Nova Alexandria, 2012. 
JONES-SHAFROTH Act. In: Wikipedia, the free encyclopedia. Disponível em: <https://en.wikipedia.org/wiki/Jones\%E2\%80\%93Shafroth_Act>. Acesso em: 27 jan. 2019.

JORGE, Fernando. Vida, obra e época de Paulo Setúbal: um homem de alma ardente. Belo Horizonte: Geração Editorial, 2008.

KOCH, Stephen. Oficina de escritores: um manual para a arte da ficção. Tradução de Marcelo Dias Almada. São Paulo: Martins Fontes, 2008.

KORNBLUH, Joyce Campos. Juca e Joyce: memórias da neta de Monteiro Lobato depoimentos a Márcia Camargos. São Paulo: Moderna, 2007.

KOSHIYAMA, Alice Mitika. Monteiro Lobato: intelectual, empresário, editor. São Paulo: Edusp, 2006.

LAMARÃO, Sérgio. Os Estados Unidos de Monteiro Lobato e as respostas ao "atraso" brasileiro. Lusotopie, Paris: Karthala, pp. 51-68, 2002.

LANDERS, Vasda Bonafini. De Jeca a Macunaíma: Monteiro Lobato e o modernismo. São Paulo: Civilização Brasileira, 1987.

LAJOLO, Marisa. Mário de Andrade e Monteiro Lobato: um diálogo modernista em três tempos. Teresa - revista de literatura brasileira, São Paulo: Faculdade de Filosofia, Letras e Ciências Humanas - USP, nº 8/9, pp. 142-60, 2008.

Monteiro Lobato: a modernidade do contra. São Paulo: Brasiliense, 1985.

Monteiro Lobato: um brasileiro sob medida. São Paulo: Moderna, 2010a.

Monteiro Lobato \& Isaac Goldberg: a América Latina na América do Norte.

Remate de males, Campinas: Universidade de Campinas - Unicamp, v. 30, nº 2, pp. 293 310, $2010 b$.

. (Org.). Monteiro Lobato, livro a livro: obra adulta. São Paulo: Editora Unesp, 2014.

LAJOLO, Marisa; CECCANTINI, João Luís (Org.). Monteiro Lobato, livro a livro: obra infantil. São Paulo: Editora Unesp: Imprensa Oficial, 2009.

LAJOLO, Marisa; SCHWARCZ, Lilia Moritz. Reinações de Monteiro Lobato. São Paulo: Companhia das Letrinhas, 2019.

LAVILLE, Christian; DIONNE, Jean. A construção do saber: manual de metodologia da pesquisa em ciências humanas. Tradução de Heloísa Monteiro e Francisco Settineri. Porto Alegre: Artmed; Belo Horizonte: Editora UFMG, 1999.

LIMA, Aldo de. (Org.). Reinações da literatura infantil e juvenil. Recife: Editora Universitária da UFPE, 2011. 
LIMA, Ronaldo; ORGADO, Gisele Tyba Mairink Redondo. Monteiro Lobato. In: Dicionário de tradutores literários no Brasil. Santa Catarina: Universidade Federal de Santa Catarina, 2013.

Disponível em: <https://dicionariodetradutores.ufsc.br/pt/MonteiroLobato.htm>. Acesso em 16 out. 2019.

LOBATO, Monteiro. América, $1^{\text {a }}$ edição. São Paulo: Companhia Editora Nacional, 1932. América. São Paulo: Editora Brasiliense, 1951a. Aritmética da Emília. São Paulo: Globo, 2009a. A barca de Gleyre. São Paulo: Globo, 2010a. . Caçadas de Pedrinho. São Paulo: Biblioteca Azul, 2015a. . Cartas escolhidas, $2^{\circ}$ volume. São Paulo: Editora Brasiliense, 1969. . A chave do tamanho. São Paulo: Círculo do Livro, 1988a. . Contos completos. São Paulo: Biblioteca Azul, 2016a. . Dom Quixote das crianças. São Paulo: Editora Brasiliense, 1965. Os doze trabalhos de Hércules. São Paulo: Círculo do Livro, 1988b. Emília no País da Gramática. São Paulo: Globo, 2009b. . O escândalo do petróleo. São Paulo: Brasiliense, 1951 b. . Fábulas. São Paulo: Círculo do Livro, 1988c. . Ferro. São Paulo: Brasiliense, 1951c. . Fragmentos, opiniões e miscelânea. São Paulo: Editora Globo, 2010 b. . Geografia de Dona Benta. São Paulo: Globinho, 2013. Hans Staden. São Paulo: Círculo do Livro, 1988d. História das invenções. São Paulo: Globinho, 2017a. História do mundo para as crianças. São Paulo: Globinho, 2015b. . Histórias diversas. São Paulo: Círculo do Livro, 1988e.

. How Henry Ford is regarded in Brazil. Tradução de Aubrey Stuart. Rio: Companhia Editora Nacional, 1926. Idéias de Jeca Tatú. São Paulo: Brasiliense, 1951d. . Memórias da Emília. São Paulo: Biblioteca Azul, 2017b. . Mister Slang e o Brasil. São Paulo: Editora Globo, 2008a. . O Minotauro. São Paulo: Círculo do Livro, 1988 f. . Peter Pan. São Paulo: Círculo do Livro, 1988g. O Picapau Amarelo. São Paulo: Círculo do Livro, 1988h. O poço do Visconde. São Paulo: Editora Globo, 2010c. 
Prefácios e entrevistas. São Paulo: Editora Globo, 2009c.

O presidente negro. São Paulo: Brasiliense, 1967.

Problema vital, Jeca Tatu e outros textos. São Paulo: Editora Globo, 2010d.

A reforma da natureza. São Paulo: Círculo do Livro, 1988 .

Reinações de Narizinho. São Paulo: Biblioteca Azul, 2015c.

O saci. São Paulo: Biblioteca Azul, 2016b.

O saci-pererê: resultado de um inquérito. São Paulo: Editora Globo, 2008 b.

Serões de Dona Benta. São Paulo: Globinho, 2014b.

Viagem ao céu. São Paulo: Biblioteca Azul, 2018.

LODGE, David. A arte da ficção. Tradução de Guilherme da Silva Braga. Porto Alegre: L\&PM, 2010.

MARTINS, Luís. O patriarca e o bacharel. São Paulo: Alameda, 2008.

MARTINS, Milena Ribeiro. Monteiro Lobato e os Estados Unidos: espectador, leitor, tradutor. Revista USP, São Paulo: Universidade de São Paulo - USP, n 112, pp. 19-28, 2017. Disponível em:

<https://www.academia.edu/36338707/Monteiro_Lobato_e_os_Estados_Unidos_espect ador_leitor_tradutor>. Acesso em: 13 jan. 2019.

MATOS, Júlia Silveira Matos; SENNA, Adriana Kivanski de. Visões sobre política: Monteiro Lobato e os EUA. In: SIMPÓSIO NACIONAL DE HISTÓRIA, 27., 2011, São Paulo. Disponível em:

<http://www.snh2011.anpuh.org/resources/anais/14/1300654090_ARQUIVO_Artigovis oessobreapoliticamonteirolobatoanpuh2011.pdf/>. Acesso em: 13 out. 2017.

MEIRELES, Cecília. Problemas da literatura infantil. Belo Horizonte: Imprensa Oficial, 1951.

MICELI, Sergio. Nacional estrangeiro: história social e cultural do modernismo artístico em São Paulo. São Paulo: Companhia das Letras, 2003.

MORAES, Marcos Antonio de. (Org.). Correspondência Mário de Andrade \& Manuel Bandeira. São Paulo: Edusp; IEB, 2001.

MOTA, Danyllo Di Giorgio Martins da. Mr. Slang e o Brasil: a escrita de Monteiro Lobato como possibilidade de interpretação da história republicana. Monções - Revista do Curso de História da UFMS/CPCX, Coxim: Editora UFMS, v. 1, nº 1, pp. 72-84, 2014. A república de Mr. Slang: opinião pública e discurso político nas crônicas de Monteiro Lobato. In: SIMPÓSIO NACIONAL DE HISTÓRIA, 26., 2011, São Paulo. Disponível em: 
<http://www.snh2011.anpuh.org/resources/anais/14/1300666657_ARQUIVO_OPINIA OPUBLICAEDISCURSOPOLITICONASCRONICASDEMONTEIROLOBATO-

ANPUHUSP.pdf/>. Acesso em: 22 out. 2017.

MUSEU MONTEIRO LOBATO. Em Nova Iorque (1927-1930). Disponível em: < http://museumonteirolobato.com.br/em-nova-iorque/>. Acesso em: 22 out. 2017.

NEEDELL, Jeffrey D. Belle Époque tropical. São Paulo: Companhia das Letras, 1993. PASSIANI, Enio. Na trilha do Jeca: Monteiro Lobato e a formação do campo literário no Brasil. São Paulo: Anpocs; EDUSC, 2003.

PATTARO, Miriam Gilberti. Uma história meio ao contrário: Um estudo sobre História do mundo para as crianças de Monteiro Lobato. São Paulo: Editora Unesp, 2013.

PÉCAUT, Daniel. Os intelectuais e a política no Brasil: entre o povo e a nação. São Paulo: Ática, 1990.

PENTEADO, J. Roberto Whitaker. Os filhos de Lobato: o imaginário infantil na ideologia do adulto. Rio de Janeiro: Editora Globo, 2011.

A presença dos EUA na obra infantil de Monteiro Lobato. Revista USP, São Paulo: Universidade de São Paulo - USP, nº 112, pp. 11-8, 2017.

Disponível em: <https://www.revistas.usp.br/revusp/article/viewFile/129724/126303>. Acesso em 27 jul. 2018.

PEREIRA, Rosane de Bastos. Metamorfases da língua lobatiana. Linguasagem. Disponível em: <http://www.letras.ufscar.br/linguasagem/edicao13/art_08.php>. Acesso em 15 jul. 2018.

PIAGET, Jean. Problemas de psicologia genética. Os pensadores. Tradução de Celia E. A. Di Piero. São Paulo: Abril Cultural, 1983.

PRADO JÚNIOR, Caio. Formação do Brasil contemporâneo. São Paulo: Companhia das Letras, 2017.

História econômica do Brasil. São Paulo: Brasiliense, 2002.

RAFFAINI, Patricia Tavares. Pequenos poemas em prosa: vestígios da leitura ficcional na infância brasileira, nas décadas de 30 e 40. São Paulo, 2008. Tese (Doutorado em História) - Departamento de História, Faculdade de Filosofia, Letras e Ciências Humanas da Universidade de São Paulo.

REBOUL, Olivier. Introdução à retórica. Traduçao de Ivone Castilho Benedetti. São Paulo: Martins Fontes, 2004. 
RIBEIRO, José Antônio Pereira. As diversas facetas de Monteiro Lobato. São Paulo: Roswitha Kempf Editores, sem data.

RIZZINI, Joel. A vida de Monteiro Lobato. São Paulo: Correio Fraterno, 1988.

ROMANO, Patrícia Aparecida Beraldo. Dona Benta: Uma mediadora de leitura em Peter Pan, de Monteiro Lobato. Caletroscópio, Ouro Preto: Universidade Federal de Ouro Preto - UFOP, v. 4, nº 6, pp. 37-53, 2016. Disponível em:

<https://www.caletroscopio.ufop.br/index.php/caletroscopio/article/viewFile/74/59>. Acesso em 30 dez. 2018.

Dona Benta: Uma Scherazade lobatiana do ensino. Disponível em: <https://linhamestra18.files.wordpress.com/2011/12/18-m4-romano.pdf>. Acesso em 30 dez. 2018.

SANDRONI, Laura. De Lobato a Bojunga: As reinações renovadas. Rio de Janeiro: Nova Fronteira, 2011.

SANTIAGO, Silviano. (Org.). Carlos \& Mário: correspondência de Carlos Drummond de Andrade e Mário de Andrade. Rio de Janeiro: Bem-Te-Vi, 2003.

SAUSSURE, Ferdinand de. Curso de linguística geral. Tradução de Antônio Chelini, José Paulo Paes e Izidoro Blikstein. São Paulo: Cultrix, 2012.

SCHWARCZ, Lilia M.; STARLING, Heloisa M. Brasil: uma biografia. São Paulo: Companhia das Letras, 2015.

SELKE, Ricardo de Castilho. Monteiro Lobato: crítico social. Florianópolis, 2012. Dissertação (Mestrado em História) - Centro de Filosofia e Ciências Humanas, Universidade Federal de Santa Catarina. Disponível em:

$<$ https://repositorio.ufsc.br/bitstream/handle/123456789/100885/311487.pdf?sequence= 1\&isAllowed=y/>. Acesso em: 22 out. 2017.

SILVA, Juliane Nadal Cavalheiro da. Narrar, olhar e ler: Lobato, os picapauzinhos e o leitor numa viagem pela narratologia. In: IV CONALI - Congresso Nacional de Linguagens em Interação, UEM; DLE; PLE; CCH, 2013. Disponível em:

<http://www.dle.uem.br/conali2013/trabalhos/58t.pdf>. Acesso em: 30 dez. 2018.

SLANG. Cambridge Dictionary, 6 jan. 2019. Disponível em:

<https://dictionary.cambridge.org/pt/dicionario/ingles/slang>. Acesso em: 6 jan. 2019.

SNOW, Richard. Ford: o homem que transformou o consumo e inventou a Era Moderna. Tradução de Luiz Euclides T. Frazão Filho. São Paulo: Saraiva, 2014.

SOPPELSA, Fernanda Bondam. Regionalidade e tradução em As Aventuras de Tom Sawyer, de Monteiro Lobato. Caxias do Sul, 2015. Dissertação (Mestrado em Letras, 
Cultura e Regionalidade) - Pós-Reitoria de Pesquisa e Pós-Graduação, Universidade de Caxias do Sul. Disponível em:

<https://repositorio.ucs.br/xmlui/bitstream/handle/11338/1075/Dissertacao\%20Fernand a\%20Bondam\%20Soppelsa.pdf?sequence=1\&isAllowed=y/>. Acesso em: 27 mai. 2018. SNOW, Richard. Ford: o homem que transformou o consumo e inventou a era moderna. Tradução de Luiz Euclides T. Frazão Filho. São Paulo: Saraiva, 2014.

SPAGNOLI, Camila Russo de Almeida. Monteiro Lobato, o leitor. São Paulo, 2014. Dissertação (Mestrado em Culturas e Identidades Nacionais) - Instituto de Estudos Brasileiros da Universidade de São Paulo. Disponível em:

<http://www.teses.usp.br/teses/disponiveis/31/31131/tde-03062014-153059/pt-br.php>. Acesso em 13 jan. 2019.

TEMPOS modernos. Dirigido e produzido por Charles Chaplin. Beverly Hills: United Artists, 1936. 1 DVD (87 min.), Warner Home Video, p\&b.

TIN, Emerson. Em busca do "Lobato das cartas": a construção da imagem de Monteiro Lobato diante de seus destinatários. Campinas, 2008. Tese (Doutorado em Teoria e História Literária) - Programa de Teoria e História Literária do Instituto de Estudos da Linguagem da Universidade Estadual de Campinas. Disponível em:

<http://repositorio.unicamp.br/jspui/handle/REPOSIP/270302>. Acesso em 9 jun. 2019. TRANSMITINDO cidadania americana. Embaixada e Consulado dos EUA no Brasil, 2019. Disponível em:

$<$ https://br.usembassy.gov/pt/u-s-citizen-services-pt/nascimento/transmitindo-cidadaniaamericana/>. Acesso em 26 mai. 2019.

VASCONCELLOS, Zinda Maria Carvalho de. O universo ideológico da obra infantil de Monteiro Lobato. São Paulo: Traço, 1982.

VERISSIMO, Erico. Breve história da literatura brasileira. Tradução de Maria da Glória Bordini. 4ª edição. São Paulo: Editora Globo, 1995.

ZÉRAFFA, Michel. Pessoa e personagem: o romanesco dos anos de 1920 aos anos de 1950. São Paulo: Perspectiva, 2010.

ZILBERMAN, Regina. (Org.). Atualidade de Monteiro Lobato: uma revisão crítica. Porto Alegre: Mercado Aberto, 1983. 
ANEXO 1. AS "IDEIAS AMERICANAS" NAS OBRAS ADULTA E INFANTIL: QUADRO COMPARATIVO

1.1. OBRA ADULTA (1926-32)

\begin{tabular}{|c|c|c|c|}
\hline & $\begin{array}{l}\text { O presidente } \\
\text { negro }(1926)\end{array}$ & $\begin{array}{l}\text { Mister Slang e o } \\
\text { Brasil (1927) }\end{array}$ & América (1932) \\
\hline $\begin{array}{l}\text { Fonte explícita } \\
\text { em que a obra } \\
\text { se baseia }\end{array}$ & $\begin{array}{l}\text { Inspirado } \\
\text { literariamente em } \\
\text { ficções como as } \\
\text { de H. G. Wells e } \\
\text { filosoficamente } \\
\text { em teorias } \\
\text { científicas/cienti- } \\
\text { ficistas como } \\
\text { as de Herbert } \\
\text { Spencer e } \\
\text { Friedrich } \\
\text { Nietzsche. } \\
\text { Romance escrito } \\
\text { no Brasil, antes } \\
\text { de Lobato fixar- } \\
\text { se como adido } \\
\text { nos Estados } \\
\text { Unidos. }\end{array}$ & $\begin{array}{l}\text { Não adapta livro } \\
\text { ou modelo } \\
\text { específico. } \\
\text { Publicado } \\
\text { originalmente em } \\
\text { formato } \\
\text { periódico em 'O } \\
\text { Jornal'. Lobato } \\
\text { depois } \\
\text { compilaria os } \\
\text { colóquios e os } \\
\text { transformaria nos } \\
\text { capítulos } \\
\text { reunidos no } \\
\text { volume. }\end{array}$ & $\begin{array}{l}\text { Baseado em } \\
\text { experiências } \\
\text { pessoais de } \\
\text { Lobato nos EUA } \\
\text { e em artigos de } \\
\text { jornal que } \\
\text { consumiu } \\
\text { enquanto morou } \\
\text { lá, segundo } \\
\text { levantamento de } \\
\text { Milena Ribeiro } \\
\text { Martins } \\
\text { localizável em } \\
\text { Monteiro Lobato, } \\
\text { livro a livro: } \\
\text { obra adulta } \\
\text { (2014). }\end{array}$ \\
\hline Café & $\begin{array}{l}\text { Referenciado } \\
\text { como bebida ou } \\
\text { como lugar } \\
\text { (cafeteria): } \\
\text { "Ideias pegadas } \\
\text { no ar do } \\
\text { escritorio, nas } \\
\text { palestras dos } \\
\text { cafés, na leitura } \\
\text { de jornais } \\
\text { redigidos por } \\
\text { criaturas tão } \\
\text { ignaras como eu" } \\
\text { (1967: 2000); } \\
\text { "Tomamos café } \\
\text { na varanda" } \\
\text { (1967: 286). }\end{array}$ & $\begin{array}{l}\text { "O café de São } \\
\text { Paulo, por } \\
\text { exemplo, não } \\
\text { passa de um } \\
\text { engenhoso meio } \\
\text { de industrializar } \\
\text { e comercializar a } \\
\text { fertilidade nativa } \\
\text { da terra roxa, que } \\
\text { constitui a riquza } \\
\text { de São Paulo, } \\
\text { como o ferro } \\
\text { constitui a } \\
\text { riqueza de } \\
\text { Minas” (2008a: } \\
\text { 65). }\end{array}$ & $\begin{array}{l}\text { "Veja no seu país } \\
\text { que desastre está } \\
\text { sendo a } \\
\text { interferencia } \\
\text { oficial no } \\
\text { negocio do café" } \\
(1951 \text { a: } 74) \text {. }\end{array}$ \\
\hline Petróleo & $\begin{array}{l}\text { Sem menção } \\
\text { direta. }\end{array}$ & $\begin{array}{l}\text { Sem menção } \\
\text { direta. }\end{array}$ & $\begin{array}{l}\text { "Mas para mover } \\
\text { a maquina têm } \\
\text { vocês de } \\
\text { mobilizar a hulha } \\
\text { e esguichar o } \\
\text { petróleo. Estão } \\
\text { cuidando disso }\end{array}$ \\
\hline
\end{tabular}




\begin{tabular}{|c|c|c|c|}
\hline & & & $\begin{array}{l}\text { também?" } \\
\text { (1951a: 276). }\end{array}$ \\
\hline Ferro & $\begin{array}{l}\text { Sem menção } \\
\text { direta. }\end{array}$ & $\begin{array}{l}\text { "Daqui a } 200 \\
\text { anos podem dar- } \\
\text { se, entre } \\
\text { inúmeras, estas } \\
\text { duas hipóteses: } \\
\text { não ter mais } \\
\text { valor nenhum o } \\
\text { ferro, graças à } \\
\text { descoberta de um } \\
\text { novo elemento, } \\
\text { ou não existirem } \\
\text { netos herdeiros } \\
\text { das tais jazidas } \\
\text { de Minas" } \\
\text { (2008a: 64). }\end{array}$ & $\begin{array}{l}\text { "Têm eles [os } \\
\text { americanos] nas } \\
\text { vísceras (...) a } \\
\text { intuição do que é } \\
\text { o ferro. Têm } \\
\text { diante dos olhos } \\
\text { o esplendor } \\
\text { duma civilização } \\
\text { saida inteirinha } \\
\text { do ferro" (1951a: } \\
\text { 275). }\end{array}$ \\
\hline $\begin{array}{l}\text { Máquina e } \\
\text { energia }\end{array}$ & $\begin{array}{l}\text { Sem menção } \\
\text { direta; Lobato } \\
\text { voltaria as } \\
\text { atenções para a } \\
\text { questão após } \\
\text { viajar aos } \\
\text { Estados Unidos e } \\
\text { observar as } \\
\text { especificidades } \\
\text { da industria- } \\
\text { lização naquele } \\
\text { país. }\end{array}$ & $\begin{array}{l}\text { Sem menção } \\
\text { direta; Lobato } \\
\text { voltaria as } \\
\text { atenções para a } \\
\text { questão após } \\
\text { viajar aos } \\
\text { Estados Unidos e } \\
\text { observar as } \\
\text { especificidades } \\
\text { da industria- } \\
\text { lização naquele } \\
\text { país. }\end{array}$ & $\begin{array}{l}\text { "Produzindo } \\
\text { ferro, terão a } \\
\text { maquina e } \\
\text { produzindo } \\
\text { carbono terão a } \\
\text { energia mecanica } \\
\text { necessaria para } \\
\text { mover a } \\
\text { maquina" } \\
\text { (1951a: 276). }\end{array}$ \\
\hline Eficiência & $\begin{array}{l}\text { "Mas ao voltar } \\
\text { os olhos para a } \\
\text { America } \\
\text { perceberia } \\
\text { fluidificado no } \\
\text { ambiente um } \\
\text { principio novo - } \\
\text { Eficiencia. (...) O } \\
\text { principio da } \\
\text { Eficiencia } \\
\text { resolvera todos } \\
\text { os problemas } \\
\text { materiais dos } \\
\text { americanos" } \\
(1967: 231) .\end{array}$ & $\begin{array}{l}\text { "Nos Estados } \\
\text { Unidos vemos a } \\
\text { eficiência como a } \\
\text { mira de tudo" } \\
\text { (2008a: } 81) \text {; "O } \\
\text { bom trabalho. O } \\
\text { trabalho dirigido } \\
\text { por um cérebro } \\
\text { que sabe o que é } \\
\text { eficiência" } \\
\text { (2008a: } 87) \text {. }\end{array}$ & $\begin{array}{l}\text { "Se eu fosse } \\
\text { resumir num } \\
\text { vocabulario esta } \\
\text { America que } \\
\text { juntos andamos a } \\
\text { "conversar', não } \\
\text { vacilaria um } \\
\text { segundo na } \\
\text { escolha da } \\
\text { palavra certa: } \\
\text { 'Eficiencia"” } \\
\text { (1951a: 279). }\end{array}$ \\
\hline Progresso & $\begin{array}{l}\text { "O grande } \\
\text { obstaculo ao } \\
\text { progresso sempre } \\
\text { foi o habito, a } \\
\text { ideia feita, a } \\
\text { preguiça de } \\
\text { constante exame } \\
\text { do unico } \\
\text { problema }\end{array}$ & $\begin{array}{l}\text { "Não haverá } \\
\text { progresso } \\
\text { possível } \\
\text { enquanto não } \\
\text { houver mudança } \\
\text { de mentalidade a } \\
\text { este respeito" } \\
\text { (2008a: 62); "A } \\
\text { concorrência é a }\end{array}$ & $\begin{array}{l}\text { "Apenas vejo no } \\
\text { progresso uma } \\
\text { lei natural" } \\
\text { (1951a: 72); } \\
\text { "É desse modo } \\
\text { que o progresso } \\
\text { se processa" } \\
\text { (1951a: } 240) \text {. }\end{array}$ \\
\hline
\end{tabular}




\begin{tabular}{|c|c|c|c|}
\hline & $\begin{array}{l}\text { material da vida } \\
\text { - o do } \\
\text { transporte" } \\
(1967: 237)\end{array}$ & $\begin{array}{l}\text { lei biológica do } \\
\text { progresso" } \\
\text { (2008a: 69). }\end{array}$ & \\
\hline Civilização & $\begin{array}{l}\text { "Repare que a } \\
\text { nossa civilização } \\
\text { industrial se cifra } \\
\text { em desenvolver a } \\
\text { roda e extrair } \\
\text { dela todas as } \\
\text { possibilidades" } \\
(1967: 237) .\end{array}$ & $\begin{array}{l}\text { Sem menção } \\
\text { direta. }\end{array}$ & $\begin{array}{l}\text { "O Destino me } \\
\text { havia posto na } \\
\text { America, país de } \\
\text { alta civilização } \\
\text { industrial" } \\
\text { (1951a: 46); } \\
\text { "Vocês possuem } \\
\text { em grande os } \\
\text { dois elementos } \\
\text { primeiros da } \\
\text { civilização: } \\
\text { oxido de ferro e } \\
\text { carbono. Por que } \\
\text { não a criam, } \\
\text { produzindo o } \\
\text { metal basico?" } \\
\text { (1951a: 275). }\end{array}$ \\
\hline $\begin{array}{l}\text { Resistência dos } \\
\text { homens médios } \\
\text { ao progresso e a } \\
\text { descobertas e } \\
\text { mudanças }\end{array}$ & $\begin{array}{l}\text { "O habito não } \\
\text { nos deixa ver os } \\
\text { defeitos" (1967: } \\
\text { 237). }\end{array}$ & $\begin{array}{l}\text { "É lógico que os } \\
\text { espíritos fracos } \\
\text { se perturbem } \\
\text { com mudanças } \\
\text { métricas. Mas } \\
\text { em atenção à } \\
\text { fraqueza de } \\
\text { espírito dos } \\
\text { homens devemos } \\
\text { permanecer sob } \\
\text { regimes viciosos } \\
\text { que sobretudo a } \\
\text { esses espíritos } \\
\text { fracos dificultam } \\
\text { a vida? O } \\
\text { momentâneo } \\
\text { prejuízo para a } \\
\text { fraqueza de } \\
\text { espírito se com- } \\
\text { pensa com todo } \\
\text { um futuro de } \\
\text { facilidades. } \\
\text { Nunca houve na } \\
\text { terra progresso } \\
\text { que não } \\
\text { perturbasse o } \\
\text { anterior } \\
\text { equilíbrio da } \\
\text { vida" (2008a: } \\
39 \text { ). }\end{array}$ & $\begin{array}{l}\text { "Nisto, como em } \\
\text { muitas outras } \\
\text { coisas, o } \\
\text { americano } \\
\text { mostra a sua } \\
\text { capacidade de } \\
\text { criar, sem } \\
\text { atenção ás } \\
\text { sugestões do } \\
\text { passado europeu. } \\
\text { Criticam-no, } \\
\text { metem-no a riso } \\
\text { os outros povos. } \\
\text { Por fim } \\
\text { acostumam-se á } \\
\text { ideia e acabam } \\
\text { fazendo o } \\
\text { mesmo" (1951a: } \\
\text { 240). }\end{array}$ \\
\hline $\begin{array}{l}\text { Uso da } \\
\text { tecnologia de } \\
\text { acordo com as }\end{array}$ & $\begin{array}{l}\text { "[O Capitólio] É } \\
\text { a casa-mestra da } \\
\text { força, a odiosa }\end{array}$ & $\begin{array}{l}\text { "Na guerra vence } \\
\text { quem chega } \\
\text { primeiro, quem }\end{array}$ & $\begin{array}{l}\text { "- O senhor ha de } \\
\text { admitir que a } \\
\text { rapidez da }\end{array}$ \\
\hline
\end{tabular}




\begin{tabular}{|c|c|c|c|}
\hline $\begin{array}{l}\text { intenções e } \\
\text { práticas } \\
\text { humanas }\end{array}$ & $\begin{array}{l}\text { cabina das } \\
\text { manivelas que } \\
\text { dirigem tudo. Ali } \\
\text { têm habitado os } \\
\text { piores monstros } \\
\text { da humanidade. } \\
\text { Moraram ali } \\
\text { Gengis-Kan, } \\
\text { Cesar, Luis 14, } \\
\text { Frederico da } \\
\text { Prussia, Pedro o } \\
\text { Grande, } \\
\text { Cromwell, todos } \\
\text { os gorilas } \\
\text { cesareos que } \\
\text { através dos } \\
\text { seculos vêm } \\
\text { trazendo preso ao } \\
\text { seu carro de } \\
\text { triunfo um ser de } \\
\text { especie diferente, } \\
\text { arrancado ao } \\
\text { companheiro } \\
\text { natural por um } \\
\text { gesto de } \\
\text { violência e } \\
\text { rapina!" (1967: } \\
\text { 246). }\end{array}$ & $\begin{array}{l}\text { atira primeiro, } \\
\text { coisas que só } \\
\text { conseguem os } \\
\text { que andam em } \\
\text { dia com a } \\
\text { evolução das } \\
\text { armas" (2008a: } \\
\text { 138); } \\
\text { "Exatamente por } \\
\text { isso preconizo o } \\
\text { avião, que é a } \\
\text { arma do pobre. } \\
\text { Couraçado é hoje } \\
\text { arma de povo } \\
\text { rico ou de povo } \\
\text { que tem metalur- } \\
\text { gia e pode cons- } \\
\text { truí-lo em casa" } \\
\text { (2008a: 138). }\end{array}$ & $\begin{array}{l}\text { maquinização } \\
\text { não dá tempo aos } \\
\text { alijados de se } \\
\text { adadptarem. } \\
\text { - Nesse caso, o } \\
\text { remedio único é } \\
\text { os alijados pre- } \\
\text { cipitarem a } \\
\text { marcha da } \\
\text { adaptação. A } \\
\text { America impõe } \\
\text { rapidez de } \\
\text { julgamento e } \\
\text { trote largo. } \\
\text { Quem fôr lerdo } \\
\text { de cabeça ou de } \\
\text { movimentos, que } \\
\text { emigre, para não } \\
\text { ser esmagado. } \\
\text { Paises onde nin- } \\
\text { guem corre não } \\
\text { faltam...” (1951a: } \\
\text { 72). }\end{array}$ \\
\hline $\begin{array}{l}\text { Trabalhadores } \\
\text { x mecanização }\end{array}$ & $\begin{array}{l}\text { "Ford provou } \\
\text { que não ha } \\
\text { hostilidade entre } \\
\text { o capital e o } \\
\text { trabalho e sim } \\
\text { mal-entendido" } \\
(1967: 205) .\end{array}$ & $\begin{array}{l}\text { “A entrada do } \\
\text { automóvel } \\
\text { perturbou o } \\
\text { equilíbrio da vida } \\
\text { mesquinha de } \\
\text { milhares de co- } \\
\text { cheiros de tílburi. } \\
\text { Mas transformou } \\
\text { esses homens. Os } \\
\text { cocheiros são } \\
\text { hoje choferes, } \\
\text { gente mais bem } \\
\text { paga e de um } \\
\text { mais alto tipo de } \\
\text { vida. Ai do } \\
\text { mundo, se em } \\
\text { atenção ao tílburi } \\
\text { e seus cocheiros } \\
\text { impedíssemos o } \\
\text { advento do } \\
\text { automóvel!" } \\
\text { (2008a: } 39-40 \text { ). }\end{array}$ & $\begin{array}{l}\text { "Cada vez que } \\
\text { aparece alguma } \\
\text { nova maquina, } \\
\text { ou nova invenção } \\
\text { - e progredir é } \\
\text { isso, maquinar, } \\
\text { inventar - criam- } \\
\text { se condições no- } \\
\text { vas de vida (...). } \\
\text { A maquina nova } \\
\text { não veiu } \\
\text { diminuir o } \\
\text { trabalho, sim } \\
\text { aumenta-lo, } \\
\text { como os fatos o } \\
\text { provam" (1951a: } \\
68 \text { ). }\end{array}$ \\
\hline $\begin{array}{l}\text { Homens de } \\
\text { visão }\end{array}$ & $\begin{array}{l}\text { "Pus-me a } \\
\text { refletir naquilo e } \\
\text { a comparar a } \\
\text { estreiteza do meu } \\
\text { cerebro com a }\end{array}$ & $\begin{array}{l}\text { "Mas acontece } \\
\text { que os homens } \\
\text { deste tipo se } \\
\text { queimam nas } \\
\text { próprias chamas. }\end{array}$ & $\begin{array}{l}\text { "O americano, } \\
\text { quando uma } \\
\text { ideia nova surge } \\
\text { (...), estuda o } \\
\text { caso, mede, }\end{array}$ \\
\hline
\end{tabular}




\begin{tabular}{|c|c|c|c|}
\hline & $\begin{array}{l}\text { amplidão do } \\
\text { cerebro da filha } \\
\text { do professor } \\
\text { Benson. Quantas } \\
\text { rodas tinha ele } \\
\text { mais do que o } \\
\text { meu! E como } \\
\text { rodavam bem } \\
\text { lubrificadas as } \\
\text { rodinhas do } \\
\text { cerebro de miss } \\
\text { Jane, todas pos- } \\
\text { tas sobre mancais } \\
\text { de bilha...” } \\
\text { (1967: 238). }\end{array}$ & $\begin{array}{l}\text { São sarças } \\
\text { perpetuamente } \\
\text { incendidas e } \\
\text { portanto } \\
\text { impolíticas. } \\
\text { Falta-lhes o } \\
\text { senso pragmático } \\
\text { do instante em } \\
\text { que vivem. } \\
\text { Olham demais } \\
\text { para o futuro. } \\
\text { Enxergam muito } \\
\text { longe e } \\
\text { tropeçam. O } \\
\text { comodismo do } \\
\text { presente, } \\
\text { incomodado, } \\
\text { sempre perseguiu } \\
\text { os ‘visionários”” } \\
\text { (2008a:131). }\end{array}$ & $\begin{array}{l}\text { calcula e, se } \\
\text { encontrou } \\
\text { vantagens, } \\
\text { adopta-a, } \\
\text { qualquer que seja } \\
\text { a opinião estran- } \\
\text { geira" (1951a: } \\
241) .\end{array}$ \\
\hline $\begin{array}{l}\text { Elogio da } \\
\text { audácia }\end{array}$ & $\begin{array}{l}\text { "Acompanhe a } \\
\text { vida de Henry } \\
\text { Ford, estude-lhe } \\
\text { as ideias. (...) Por } \\
\text { mais audacioso } \\
\text { que nos pareça o } \\
\text { pensamento de } \\
\text { Henry Ford, que } \\
\text { é ele senão o } \\
\text { reflexo do mais } \\
\text { elementar bom } \\
\text { senso? (...) No } \\
\text { entanto, tamanha } \\
\text { é a crosta que } \\
\text { nos recobre o } \\
\text { bom senso } \\
\text { natural que Ford } \\
\text { nos parece um } \\
\text { messias da Ideia } \\
\text { Nova" (1967: } \\
\text { 202). }\end{array}$ & $\begin{array}{l}\text { "Pela sua in- } \\
\text { dependência de } \\
\text { ideias?" (2008a: } \\
21) ; \\
\text { "- No entanto, } \\
\text { eles [os homens } \\
\text { audaciosos] } \\
\text { vencem... } \\
\text { - Vencem, ou, } \\
\text { antes, fazem que } \\
\text { vença a ideia que } \\
\text { os apaixona. Mas } \\
\text { pagam a vitória } \\
\text { com a vida. É de } \\
\text { todos os tempos } \\
\text { e todos os } \\
\text { povos" (2008a: } \\
\text { 131). }\end{array}$ & $\begin{array}{l}\text { "Tudo quanto } \\
\text { existe foi criado. } \\
\text { Um dia nasceu. } \\
\text { Alguem abriu } \\
\text { caminho. } \\
\text { Admitir que os } \\
\text { outros possam } \\
\text { abrir caminho e a } \\
\text { gente não, não é } \\
\text { reconhecer-se } \\
\text { visceralmente } \\
\text { incapaz?" } \\
\text { (1951a: } 241)\end{array}$ \\
\hline $\begin{array}{l}\text { Indústrias Ford, } \\
\text { Henry Ford }\end{array}$ & $\begin{array}{l}\text { "Foi, pois, com o } \\
\text { maior enlevo } \\
\text { d'alma que entrei } \\
\text { certa manhã } \\
\text { numa agencia e } \\
\text { comprei a } \\
\text { maquina que me } \\
\text { mudaria a } \\
\text { situação social. } \\
\text { Um Ford" (1967: } \\
\text { 132); "hoje é } \\
\text { Henry Ford o } \\
\text { líder nato da } \\
\text { industria ameri- }\end{array}$ & $\begin{array}{l}\text { "Depois que } \\
\text { Henry Ford } \\
\text { demonstrou } \\
\text { como se } \\
\text { aproveitam até } \\
\text { cegos e aleijados, } \\
\text { ninguém tem o } \\
\text { direito de alegar } \\
\text { o não presta" } \\
\text { (2008a: 42); "Há } \\
\text { dias li no Today } \\
\text { and tomorrow, } \\
\text { do grande Henry } \\
\text { Ford, um livro }\end{array}$ & $\begin{array}{l}\text { "Um Ford no } \\
\text { fundo do quintal" } \\
\text { (1951a: 66); } \\
\text { "Esse Ford } \\
\text { inconcebivel, } \\
\text { cabrito de aço } \\
\text { mais abundante } \\
\text { nesta terra de Tio } \\
\text { Sam do que } \\
\text { besouros num } \\
\text { país tropical" } \\
\text { (1951a: 67); } \\
\text { "O genio de } \\
\text { Henry Ford não }\end{array}$ \\
\hline
\end{tabular}




\begin{tabular}{|c|c|c|c|}
\hline & $\begin{array}{l}\text { cana em virtude } \\
\text { da higidez } \\
\text { universalmente } \\
\text { reconhecida das } \\
\text { suas ideias e } \\
\text { realizações" } \\
(1967: 286) .\end{array}$ & $\begin{array}{l}\text { que está fazendo } \\
\text { furor no mundo } \\
\text { mas que vocês } \\
\text { inocentemente } \\
\text { ignoram, uma } \\
\text { opinião sobre o } \\
\text { Brasil" (2008a: } \\
\text { 104). }\end{array}$ & $\begin{array}{l}\text { constitue uma } \\
\text { exceção, um } \\
\text { fenomeno } \\
\text { isolado, (...) não } \\
\text { passa da } \\
\text { individualização } \\
\text { do genio da } \\
\text { America" } \\
\text { (1951a: 280). }\end{array}$ \\
\hline Arranha-céus & $\begin{array}{l}\text { Sem menção } \\
\text { direta. }\end{array}$ & $\begin{array}{l}\text { Sem menção } \\
\text { direta. }\end{array}$ & $\begin{array}{l}\text { "Tem o arranha- } \\
\text { ceu alguma coisa } \\
\text { que ver com o } \\
\text { tipo classico da } \\
\text { habitação? (...) } \\
\text { Visite o } \\
\text { Chrysler, Wo- } \\
\text { olworth e o Em- } \\
\text { pire State } \\
\text { Building e mais } \\
\text { cem ou duzentos } \\
\text { aqui em New } \\
\text { York" (1951a: } \\
\text { 107). }\end{array}$ \\
\hline $\begin{array}{l}\text { Professor } \\
\text { autorizado }\end{array}$ & $\begin{array}{l}\text { "Tenho } \\
\text { confiança em ti e } \\
\text { espero que } \\
\text { passado o rude } \\
\text { momento te } \\
\text { conformes com a } \\
\text { situação, } \\
\text { buscando } \\
\text { conforto no } \\
\text { estoicismo que te } \\
\text { ensinei e de que } \\
\text { te dei exemplo } \\
\text { em vida" (1967: } \\
\text { 189); "Meu pai } \\
\text { ensinou-me o } \\
\text { estoicismo, mas } \\
\text { é bem dificil o } \\
\text { estoicismo nos } \\
\text { grandes } \\
\text { momentos de } \\
\text { dor. O estoi- } \\
\text { cismo é uma ati- } \\
\text { tude..." (1967: } \\
\text { 197). }\end{array}$ & $\begin{array}{l}\text { "Absorveu-se em } \\
\text { estudos das } \\
\text { nossas coisas" } \\
(2008 \text { a: } 21) .\end{array}$ & $\begin{array}{l}\text { "Mr. Slang } \\
\text { nascera } \\
\text { equilibradissimo } \\
\text { de faculdades e } \\
\text { passara a vida a } \\
\text { manter e aper- } \\
\text { feiçoar esse } \\
\text { equilibrio" } \\
\text { (1951a: 7); } \\
\text { "explicou o meu } \\
\text { amigo, sempre } \\
\text { afiado em ma- } \\
\text { teria de nume- } \\
\text { ros" (1951a: 95) }\end{array}$ \\
\hline $\begin{array}{l}\text { Retórica, } \\
\text { métodos e } \\
\text { resultados do } \\
\text { professor }\end{array}$ & $\begin{array}{l}\text { "[O professor } \\
\text { Benson] Viu que } \\
\text { o discipulo } \\
\text { aprendia } \\
\text { depressa e, } \\
\text { voltando atrás, } \\
\text { como se valesse }\end{array}$ & $\begin{array}{l}\text { “confesso que só } \\
\text { aclarei as minhas } \\
\text { ideias depois que } \\
\text { ele mas varreu } \\
\text { com a vassoura } \\
\text { do seu bom } \\
\text { senso }\end{array}$ & $\begin{array}{l}\text { "só então, graças } \\
\text { a Mr. Slang, eu } \\
\text { começava a } \\
\text { entender" } \\
\text { (1951a: 19); } \\
\text { "Assim falou Mr. } \\
\text { Slang e eu rendi- }\end{array}$ \\
\hline
\end{tabular}




\begin{tabular}{|c|c|c|c|}
\hline & $\begin{array}{l}\text { a pena instrui-lo } \\
\text { mais a fundo, } \\
\text { passou a } \\
\text { explicar-me } \\
\text { dezenas de coisas } \\
\text { do seu laborato- } \\
\text { rio" (1967: 153); } \\
\text { "Foi com miss } \\
\text { Jane que aprendi } \\
\text { a pensar" (1967: } \\
\text { 202); "Enquanto } \\
\text { miss Jane falava, } \\
\text { naquele tom } \\
\text { impessoal e frio } \\
\text { de sabio a fazer } \\
\text { conferencia } \\
\text { publica, toda ela } \\
\text { cerebro e cultas } \\
\text { expressões na } \\
\text { boca" (1967: } \\
\text { 239). }\end{array}$ & $\begin{array}{l}\text { raciocinante" } \\
\text { (2008a: } 25) \text {; } \\
\text { "Meu método de } \\
\text { trabalho mental } \\
\text { consiste em } \\
\text { refletir, concluir } \\
\text { de mim para } \\
\text { mim, chegar a } \\
\text { ideias que sejam } \\
\text { produtos lógicos } \\
\text { de todas as ob- } \\
\text { servações e } \\
\text { conclusões } \\
\text { anteriores da mi- } \\
\text { nha vida" } \\
\text { (2008a: } 25) \text {. }\end{array}$ & $\begin{array}{l}\text { me aos seus ar- } \\
\text { gumentos. (...) } \\
\text { Convenci-me, } \\
\text { não havia } \\
\text { remedio. Mr. } \\
\text { Slang tinha um } \\
\text { modo de } \\
\text { argumentar que } \\
\text { era só dele" } \\
\text { (1951a: } 177) .\end{array}$ \\
\hline $\begin{array}{l}\text { Crítica ao } \\
\text { militarismo }\end{array}$ & $\begin{array}{l}\text { "O ministro da } \\
\text { Paz tomou a } \\
\text { palavra (as } \\
\text { guerras haviam } \\
\text { cessado no } \\
\text { mundo depois } \\
\text { que aos ministros } \\
\text { da Guerra se } \\
\text { substituiram os } \\
\text { ministros da } \\
\text { Paz)" (1967: } \\
\text { 261). }\end{array}$ & $\begin{array}{l}\text { "A revolução } \\
\text { esteve, está e } \\
\text { estará no Sul } \\
\text { enquanto a arma } \\
\text { erguida contra } \\
\text { ela for a espada e } \\
\text { não a balança da } \\
\text { justiça" (2008a: } \\
\text { 57); "É o meio } \\
\text { prático de evitar } \\
\text { que se extingam } \\
\text { os levantes e } \\
\text { com eles a } \\
\text { indústria da } \\
\text { repressão (...), } \\
\text { uma das mais } \\
\text { rendosas que o } \\
\text { homem ainda } \\
\text { inventou. } \\
\text { Encarta-se nas } \\
\text { indústrias de } \\
\text { guerra. É a que } \\
\text { permite ao } \\
\text { profiteur maiores } \\
\text { lucros, em troca } \\
\text { de menos } \\
\text { serviços, em } \\
\text { menor espaço de } \\
\text { tempo" (2008a: } \\
\text { 56). }\end{array}$ & $\begin{array}{l}\text { "Só chorou } \\
\text { Lincoln, o } \\
\text { condutor de uma } \\
\text { das } \\
\text { maiores guerras } \\
\text { que a historia } \\
\text { registra. } \\
\text { Lagrimas de } \\
\text { vitorioso, } \\
\text { causadas pela } \\
\text { euforia do } \\
\text { triunfo? Não. } \\
\text { Lagrimas de } \\
\text { Lincoln. Lagri- } \\
\text { mas de piedade, } \\
\text { de dó, de dôr } \\
\text { ante os extremos } \\
\text { a que a incom- } \\
\text { preensão dos } \\
\text { seus verdadeiros } \\
\text { interesses arrasta } \\
\text { os pobres seres } \\
\text { humanos" } \\
\text { (1951a: 44). }\end{array}$ \\
\hline $\begin{array}{l}\text { Experiências de } \\
\text { Lobato nos } \\
\text { EUA }\end{array}$ & $\begin{array}{l}\text { Lobato ainda iria } \\
\text { aos Estados } \\
\text { Unidos; seus } \\
\text { conhecimentos }\end{array}$ & $\begin{array}{l}\text { Lobato ainda iria } \\
\text { aos Estados } \\
\text { Unidos; seus } \\
\text { comentários }\end{array}$ & $\begin{array}{l}\text { O livro inteiro } \\
\text { serve-se das } \\
\text { experiências } \\
\text { empíricas de }\end{array}$ \\
\hline
\end{tabular}




\begin{tabular}{|c|c|c|c|}
\hline & $\begin{array}{l}\text { sobre o país, no } \\
\text { momento de } \\
\text { publicação de } O \\
\text { presidente negro, } \\
\text { são teóricos, } \\
\text { convencionais ou } \\
\text { supostos. }\end{array}$ & $\begin{array}{l}\text { sobre o país, no } \\
\text { momento de } \\
\text { publicação de } \\
\text { Mister Slang e o } \\
\text { Brasil, são acima } \\
\text { de tudo fruto de } \\
\text { pesquisas em } \\
\text { periódicos e } \\
\text { livros. }\end{array}$ & $\begin{array}{l}\text { Lobato nos EUA: } \\
\text { fala do que via } \\
\text { no cinema, nos } \\
\text { livros, nos } \\
\text { costumes, nos } \\
\text { prédios, nos } \\
\text { noticiários, nos } \\
\text { hábitos } \\
\text { cotidianos das } \\
\text { pessoas etc. }\end{array}$ \\
\hline $\begin{array}{l}\text { Críticas de } \\
\text { Lobato aos EUA }\end{array}$ & $\begin{array}{l}\text { No capítulo XVI } \\
\text { de } O \text { presidente } \\
\text { negro Lobato faz } \\
\text { uma fantasiosa } \\
\text { rememoração das } \\
\text { causas e efeitos } \\
\text { da segregação } \\
\text { racial e } \\
\text { escravidão nos } \\
\text { Estados Unidos: } \\
\text { "As algemas } \\
\text { cairam dos } \\
\text { pulsos mas o es- } \\
\text { tigma ficou. As } \\
\text { algemas de ferro } \\
\text { foram } \\
\text { substituidas pelas } \\
\text { algemas morais } \\
\text { do pária. O socio } \\
\text { branco negava ao } \\
\text { socio negro a } \\
\text { participação de } \\
\text { lucros morais na } \\
\text { obra comum. } \\
\text { Negava a } \\
\text { igualdade e } \\
\text { negava a } \\
\text { fraternidade, } \\
\text { embora a Lei, } \\
\text { que paira serena } \\
\text { acima do sangue, } \\
\text { consagrasse a } \\
\text { equiparação dos } \\
\text { dois sócios” } \\
\text { (1967: 252). }\end{array}$ & $\begin{array}{l}\text { "[A Detroit- } \\
\text { Toledo e Ironton] } \\
\text { Foi uma espécie } \\
\text { de 'Central' dos } \\
\text { Estados Unidos. } \\
\text { Nunca deu lucro, } \\
\text { arrecadava } 100 \text { e } \\
\text { gastava } 150 \text {, } \\
\text { servindo } \\
\text { pessimamente ao } \\
\text { público. Quebrou } \\
\text { diversas vezes, } \\
\text { foi reorganizada } \\
\text { outras tantas e } \\
\text { por fim se tornou } \\
\text { a armadilha } \\
\text { financeira mais } \\
\text { duvidosa da } \\
\text { Améririca. } \\
\text { Chegou a cair em } \\
\text { abandono. Estava } \\
\text { nesse miserável } \\
\text { estado quando } \\
\text { Henry Ford a } \\
\text { adquiriu" } \\
\text { (2008a: } 86 \text { ). }\end{array}$ & $\begin{array}{l}\text { "Dei uma } \\
\text { gargalhada, isto } \\
\text { é, comecei a dar } \\
\text { uma gargalhada á } \\
\text { moda indigena. } \\
\text { Vi, porém, que } \\
\text { estava numa terra } \\
\text { onde receber um } \\
\text { fato desses com } \\
\text { uma gargalhada } \\
\text { podia até ser } \\
\text { caso de } \\
\text { deportação por } \\
\text { 'atividades co- } \\
\text { munistas', e } \\
\text { recolhi-a a } \\
\text { tempo" (1951a: } \\
\text { 23); "o maior } \\
\text { perigo da } \\
\text { America está } \\
\text { justamente no } \\
\text { moralista de } \\
\text { profissão que } \\
\text { entende de } \\
\text { regular tudo, } \\
\text { desde o que o } \\
\text { povo veste até o } \\
\text { que o povo lê ou } \\
\text { pensa [censura]" } \\
\text { (1951a: 190). }\end{array}$ \\
\hline $\begin{array}{l}\text { Menções } \\
\text { culturais }\end{array}$ & $\begin{array}{l}\text { "O beijo que } \\
\text { num estudio de } \\
\text { Los Angeles } \\
\text { Gloria Swanson } \\
\text { começa a receber } \\
\text { de Valentino..." } \\
\text { (1967: 161); } \\
\text { "Nem as Mil e } \\
\text { Uma Noites, nem } \\
\text { Edgard Poe-- }\end{array}$ & $\begin{array}{l}\text { "- Que acha, } \\
\text { Mister Slang, de } \\
\text { Terra desuma- } \\
\text { na? } \\
\text { (...) } \\
\text { - Um retrato de } \\
\text { corpo inteiro, } \\
\text { feito por um } \\
\text { mestre retratista. } \\
\text { (...) Um tanto }\end{array}$ & $\begin{array}{l}\text { Inúmeras } \\
\text { menções a livros, } \\
\text { artistas, filmes. } \\
\text { Algumas: } \\
\text { "Andava a ler } \\
\text { Washington } \\
\text { Irving, o } \\
\text { incomparável" } \\
\text { (1951a: 91); } \\
\text { "Não quero }\end{array}$ \\
\hline
\end{tabular}




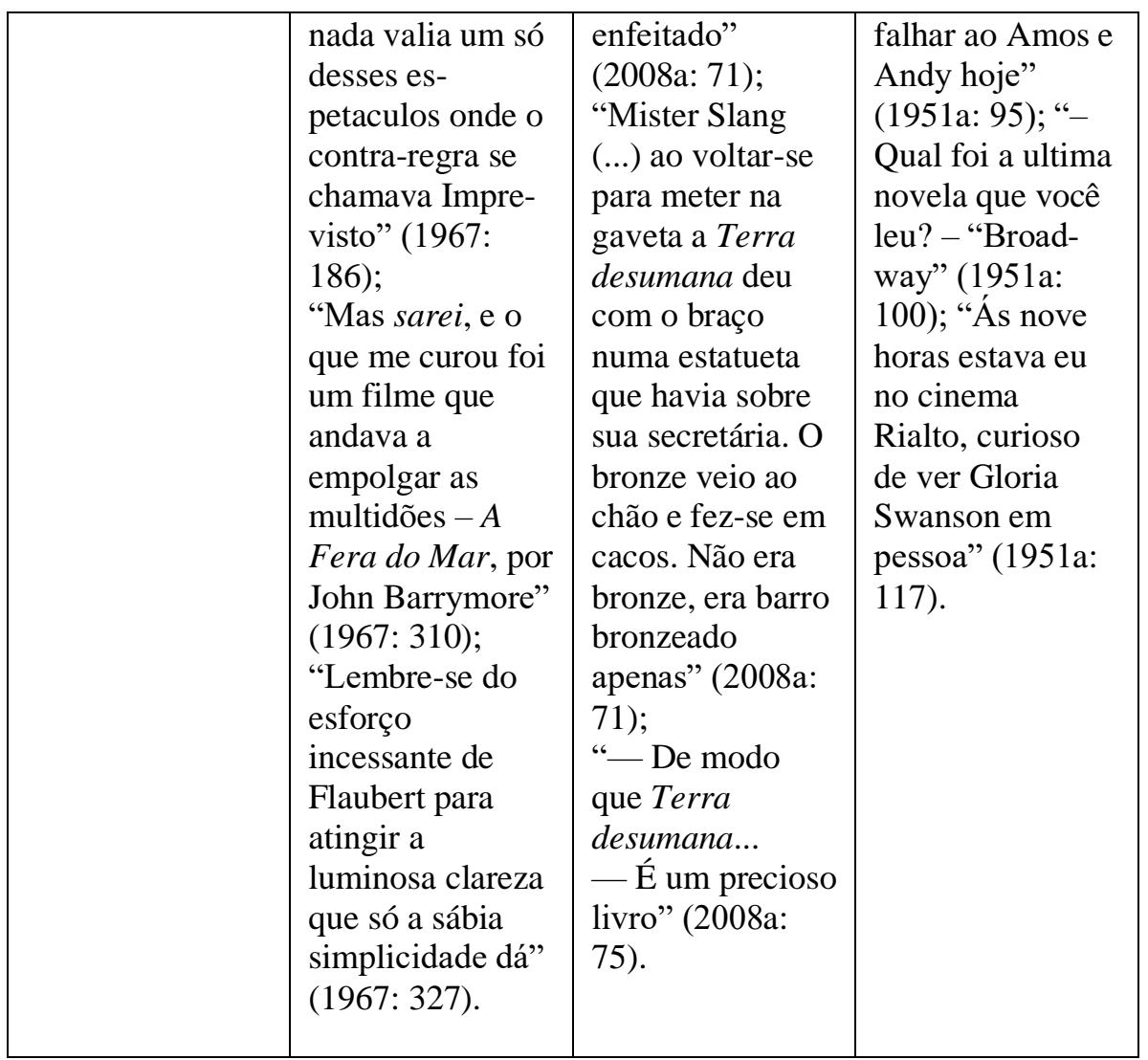

1.2. OBRA INFANTIL (1933-7)

\begin{tabular}{|c|c|c|c|c|c|}
\hline & $\begin{array}{l}\text { História do } \\
\text { mundo para } \\
\text { as crianças } \\
\text { (1933) }\end{array}$ & $\begin{array}{l}\text { Geografia de } \\
\text { Dona Benta } \\
\text { (1935) }\end{array}$ & $\begin{array}{l}\text { História das } \\
\text { invenções } \\
\text { (1935) }\end{array}$ & $\begin{array}{l}\text { O poço do } \\
\text { Visconde } \\
\text { (1937) }\end{array}$ & $\begin{array}{l}\text { Serões de } \\
\text { Dona Benta } \\
\text { (1937) }\end{array}$ \\
\hline $\begin{array}{l}\text { Fonte } \\
\text { explícita em } \\
\text { que a obra se } \\
\text { baseia }\end{array}$ & $\begin{array}{l}\text { "Uma tarde o } \\
\text { correio } \\
\text { trouxe-lhe a } \\
\text { Child's } \\
\text { history of the } \\
\text { world [1924], } \\
\text { de V. M. } \\
\text { Hillyer, } \\
\text { diretor da } \\
\text { Calvert } \\
\text { School, de } \\
\text { Baltimore" } \\
\text { (2015b: 14); } \\
\text { "vou contar a } \\
\text { coisa como } \\
\text { está explicada } \\
\text { no livro de } \\
\text { Mister } \\
\text { Hillyer" } \\
\text { (2015b: 149). }\end{array}$ & $\begin{array}{l}\text { Van Loon's } \\
\text { Geography: } \\
\text { The Story of } \\
\text { the World We } \\
\text { Live in } \\
\text { (Hendrik van } \\
\text { Loon, 1932). }\end{array}$ & $\begin{array}{l}\text { The story of } \\
\text { inventions: } \\
\text { Man, the } \\
\text { Miracle } \\
\text { Maker } \\
\text { (Hendrik van } \\
\text { Loon, 1934). }\end{array}$ & $\begin{array}{l}\text { Não se tem } \\
\text { noticia de } \\
\text { livro parecido } \\
\text { escrito para } \\
\text { crianças ou } \\
\text { jovens no } \\
\text { período; } \\
\text { algumas das } \\
\text { informações, } \\
\text { dados e } \\
\text { processos } \\
\text { descritos no } \\
\text { livro são fruto } \\
\text { da pesquisa } \\
\text { pessoal de } \\
\text { Lobato, como } \\
\text { demonstra } \\
\text { sua obra } \\
\text { anterior } O \\
\text { escândalo do }\end{array}$ & $\begin{array}{l}\text { Não adapta } \\
\text { nenhum livro } \\
\text { específico, } \\
\text { mas segue os } \\
\text { modelos e } \\
\text { estruturas de } \\
\text { suas versões } \\
\text { de obras de } \\
\text { Van Loon e } \\
\text { Hillyer. }\end{array}$ \\
\hline
\end{tabular}




\begin{tabular}{|c|c|c|c|c|c|}
\hline & & & & $\begin{array}{l}\text { petróleo } \\
\text { (1936, } \\
\text { adulta). }\end{array}$ & \\
\hline Café & $\begin{array}{l}\text { “Até eu sou } \\
\text { produtora de } \\
\text { café. O ano } \\
\text { passado vendi } \\
\text { duas mil } \\
\text { arrobas, que } \\
\text { neste } \\
\text { momento } \\
\text { estão... Onde } \\
\text { estarão? Em } \\
\text { que país } \\
\text { estará sendo } \\
\text { bebido o meu } \\
\text { cafezinho do } \\
\text { ano passado? } \\
\text { - Quem sabe } \\
\text { se na Arábia, } \\
\text { vovó! - } \\
\text { sugeriu } \\
\text { Pedrinho. } \\
\text { - Pode ser. } \\
\text { Como } \\
\text { também pode } \\
\text { ser que o } \\
\text { estejam } \\
\text { queimando lá } \\
\text { em Santos...” } \\
\text { (2015b: 170- } \\
\text { 1). }\end{array}$ & $\begin{array}{l}\text { "Depois de } \\
\text { toda essa } \\
\text { trabalheira } \\
\text { [cultivo, } \\
\text { distribuição], } \\
\text { o café é } \\
\text { amontoado e } \\
\text { queimado" } \\
\text { (2013: 51); } \\
\text { "Ainda não } \\
\text { chegamos ao } \\
\text { hotel e já } \\
\text { ganhei mais } \\
\text { dinheiro do } \\
\text { que com uma } \\
\text { safra inteira } \\
\text { de café lá no } \\
\text { sítio" (2013: } \\
\text { 106); "Era } \\
\text { cafezinho lá } \\
\text { do sítio. Tia } \\
\text { Nastácia } \\
\text { trouxera duas } \\
\text { sacas, do } \\
\text { pouco } \\
\text { escapado às } \\
\text { fogueiras da } \\
\text { grande } \\
\text { queima" } \\
\text { (2013: 202- } \\
\text { 3); "O } \\
\text { Destino me } \\
\text { plantou } \\
\text { naquele sítio } \\
\text { como } \\
\text { fazendeira de } \\
\text { café" (2013: } \\
\text { 208). }\end{array}$ & $\begin{array}{l}\text { "No dia em } \\
\text { que o café } \\
\text { subir eu } \\
\text { compro um } \\
\text { dínamo" } \\
(2017 \mathrm{a}: 42) .\end{array}$ & $\begin{array}{l}\text { Sem menção } \\
\text { direta. }\end{array}$ & $\begin{array}{l}\text { Sem menção } \\
\text { direta. }\end{array}$ \\
\hline Petróleo & $\begin{array}{l}\text { Sem menção } \\
\text { direta. }\end{array}$ & $\begin{array}{l}\text { "O petróleo é } \\
\text { o rei dos } \\
\text { combustíveis } \\
\text { modernos, de } \\
\text { modo que só } \\
\text { são fortes, } \\
\text { ricos e } \\
\text { respeitados os } \\
\text { países que o } \\
\text { possuem" } \\
\text { (2013: 49); } \\
\text { "No Brasil há } \\
\text { petróleo em } \\
\text { quantidades }\end{array}$ & $\begin{array}{l}\text { "Mas então o } \\
\text { petróleo é } \\
\text { realmente } \\
\text { uma } \\
\text { substância } \\
\text { maravilhosa" } \\
\text { (2017a: } 74) \text {. }\end{array}$ & $\begin{array}{l}\text { O livro inteiro } \\
\text { trata de } \\
\text { petróleo e } \\
\text { assuntos } \\
\text { correlacio- } \\
\text { nados. Entre } \\
\text { as inúmeras } \\
\text { menções, } \\
\text { destacamos: } \\
\text { “- Então por } \\
\text { que não se } \\
\text { perfura no } \\
\text { Brasil? }\end{array}$ & $\begin{array}{l}\text { "E agora, nos } \\
\text { países ricos } \\
\text { em petróleo- } \\
\text { nesse petróleo } \\
\text { que está se } \\
\text { tornando o rei } \\
\text { dos } \\
\text { combustíveis" } \\
\text { (2014b: } 102) \text {. }\end{array}$ \\
\hline
\end{tabular}




\begin{tabular}{|c|c|c|c|c|c|}
\hline & & $\begin{array}{l}\text { imensas, mas } \\
\text { para tirá-lo é } \\
\text { preciso } \\
\text { perfurar a } \\
\text { terra" (2013: } \\
84) \text {. }\end{array}$ & & $\begin{array}{l}\text { - Porque as } \\
\text { companhias } \\
\text { estrangeiras } \\
\text { que nos } \\
\text { vendem } \\
\text { petróleo não } \\
\text { têm interesse } \\
\text { nisso" } \\
(2010 c: 50) \text {. }\end{array}$ & \\
\hline Ferro & $\begin{array}{l}\text { "Não existe } \\
\text { nada, } \\
\text { absolutamen- } \\
\text { te nada, de } \\
\text { tudo quanto o } \\
\text { homem faz no } \\
\text { mundo de } \\
\text { hoje, que não } \\
\text { tenha por } \\
\text { base o fogo e } \\
\text { o ferro" } \\
\text { (2015b: 23); } \\
\text { "Também } \\
\text { inventaram, } \\
\text { no campo } \\
\text { metalúrgico, } \\
\text { meios de } \\
\text { temperar o } \\
\text { ferro, fazendo } \\
\text { o aço" } \\
\text { (2015b: 171). }\end{array}$ & $\begin{array}{l}\text { "Ferro e } \\
\text { petróleo, eis } \\
\text { os dois } \\
\text { elementos } \\
\text { básicos da } \\
\text { grandeza dos } \\
\text { povos } \\
\text { modernos" } \\
\text { (2013: 49); } \\
\text { "Os ingleses, } \\
\text { mais fortes } \\
\text { por causa do } \\
\text { ferro e do } \\
\text { carvão de que } \\
\text { dispunham..." } \\
\text { (2013: 178); } \\
\text { "Esse carvão } \\
\text { de pedra, } \\
\text { mais o ferro, } \\
\text { foi o que deu } \\
\text { a vitória aos } \\
\text { ingleses" } \\
\text { (2013: 222). }\end{array}$ & $\begin{array}{l}\text { "Como } \\
\text { possuísse } \\
\text { ferro e carvão } \\
\text { em } \\
\text { abundância, } \\
\text { construiu } \\
\text { máquinas } \\
\text { inúmeras para } \\
\text { tudo" (2017a: } \\
\text { 73). }\end{array}$ & $\begin{array}{l}\text { "O grande } \\
\text { valor do } \\
\text { petróleo é } \\
\text { aliar-se ao } \\
\text { ferro para } \\
\text { aumento da } \\
\text { eficiência do } \\
\text { homem" } \\
\text { (2010c: 62); } \\
\text { "Por isso vivo } \\
\text { dizendo que } \\
\text { sem produzir } \\
\text { ferro e tirar e } \\
\text { queimar } \\
\text { petróleo em } \\
\text { grandes } \\
\text { quantidades, } \\
\text { como os } \\
\text { Estados } \\
\text { Unidos, o } \\
\text { Brasil não } \\
\text { ganhará im- } \\
\text { pulso" } \\
\text { (2010c: 63). }\end{array}$ & $\begin{array}{l}\text { "O ferro é a } \\
\text { substância } \\
\text { com que o } \\
\text { homem } \\
\text { constrói suas } \\
\text { máquinas" } \\
\text { (2014b: 178). }\end{array}$ \\
\hline $\begin{array}{l}\text { Máquina e } \\
\text { energia }\end{array}$ & $\begin{array}{l}\text { “O papel faz- } \\
\text { se com o ma- } \\
\text { chado de } \\
\text { ferro que } \\
\text { corta a } \\
\text { árvore, com a } \\
\text { máquina de } \\
\text { ferro que des- } \\
\text { dobra a pasta } \\
\text { de madeira } \\
\text { em } \\
\text { camadinhas } \\
\text { finas, com as } \\
\text { calandras de } \\
\text { ferro que } \\
\text { imprensam } \\
\text { essa } \\
\text { camadinha, } \\
\text { tudo isso } \\
\text { sempre } \\
\text { ajudado pelo } \\
\text { calor - isto é, }\end{array}$ & $\begin{array}{l}\text { “máquinas } \\
(\text {...) - as } \\
\text { engenhocas } \\
\text { com que os } \\
\text { ingleses e } \\
\text { americanos } \\
\text { encheram o } \\
\text { mundo, feitas } \\
\text { de ferro e } \\
\text { movidas pelo } \\
\text { vapor, pe-la } \\
\text { eletricidade, } \\
\text { pela gasolina" } \\
\text { (2013: 154); } \\
\text { "Ferro e } \\
\text { combustível: } \\
\text { só os povos } \\
\text { que dispõem } \\
\text { desses } \\
\text { elementos } \\
\text { criadores da } \\
\text { Máquina }\end{array}$ & $\begin{array}{l}\text { “O imenso } \\
\text { Império } \\
\text { Britânico (...) } \\
\text { foi formado à } \\
\text { custa do ferro } \\
\text { e do carvão } \\
\text { transformados } \\
\text { em máquina e } \\
\text { energia" } \\
\text { (2017a: 73). }\end{array}$ & $\begin{array}{l}\text { "O mundo } \\
\text { ficou pequeno } \\
\text { depois que o } \\
\text { petróleo veio } \\
\text { mover as } \\
\text { máquinas que } \\
\text { o homem } \\
\text { constrói com } \\
\text { o ferro" } \\
\text { (2010c: 63); } \\
\text { "o problema } \\
\text { do Brasil é } \\
\text { um só: } \\
\text { produzir ferro } \\
\text { e petróleo } \\
\text { para com eles } \\
\text { ter a máquina } \\
\text { que } \\
\text { aumentará a } \\
\text { eficiência do } \\
\text { brasileiro" } \\
\text { (2010c: 64). }\end{array}$ & $\begin{array}{l}\text { "A base [da } \\
\text { civilização] é } \\
\text { o ferro e a } \\
\text { energia que } \\
\text { move as } \\
\text { máquinas } \\
\text { construídas } \\
\text { de ferro" } \\
\text { (2014b: 183). }\end{array}$ \\
\hline
\end{tabular}




\begin{tabular}{|c|c|c|c|c|c|}
\hline & $\begin{array}{l}\text { pelo fogo" } \\
\text { (2015b: 23). }\end{array}$ & $\begin{array}{l}\text { governam o } \\
\text { mundo" } \\
(2013: 170) .\end{array}$ & & & \\
\hline Eficiência & $\begin{array}{l}\text { Sem menção } \\
\text { direta. }\end{array}$ & $\begin{array}{l}\text { Sem menção } \\
\text { direta. }\end{array}$ & $\begin{array}{l}\text { "O homem } \\
\text { ganhou } \\
\text { eficiência, } \\
\text { (...) um poder } \\
\text { tão grande } \\
\text { que o fez rei } \\
\text { da Terra" } \\
\text { (2017a: } 24) \text {; } \\
\text { "Para libertar- } \\
\text { se do esforço, } \\
\text { o homem foi } \\
\text { aumentando a } \\
\text { sua } \\
\text { eficiência" } \\
\text { (2017a: 26). }\end{array}$ & $\begin{array}{l}\text { “_E se em } \\
\text { vez de ter a } \\
\text { sua eficiência } \\
\text { aumentada } \\
\text { pelas quatro } \\
\text { pernas do } \\
\text { cavalo, você a } \\
\text { tiver } \\
\text { aumentada } \\
\text { pelas quatro } \\
\text { rodas de um } \\
\text { automóvel?" } \\
\text { (2010c: 63); } \\
\text { "a máquina } \\
\text { aumenta a } \\
\text { eficiência do } \\
\text { homem” } \\
\text { (2010c: 64) }\end{array}$ & $\begin{array}{l}\text { "Isso } \\
\text { [conhecer as } \\
\text { forças da } \\
\text { natureza] deu } \\
\text { ao homem } \\
\text { eficiência, } \\
\text { isto é, } \\
\text { capacidade de } \\
\text { fazer coisas" } \\
\text { (2014b: } 14) \text {. }\end{array}$ \\
\hline Progresso & $\begin{array}{l}\text { “A marcha do } \\
\text { progresso é } \\
\text { hoje tão } \\
\text { rápida que } \\
\text { nem dá tempo } \\
\text { ao homem de } \\
\text { adaptar-se às } \\
\text { novas } \\
\text { condições que } \\
\text { os inventos } \\
\text { vão criando" } \\
(2015 b: 225) \text {. }\end{array}$ & $\begin{array}{l}\text { "Só a } \\
\text { necessidade é } \\
\text { que faz o } \\
\text { homem } \\
\text { progredir" } \\
\text { (2013: 166- } \\
\text { 7). }\end{array}$ & $\begin{array}{l}\text { "Progresso } \\
\text { quer dizer } \\
\text { isso: fazer as } \\
\text { coisas cada } \\
\text { vez com } \\
\text { menor } \\
\text { esforço" } \\
(2017 \mathrm{a}: 26) \text {. }\end{array}$ & $\begin{array}{l}\text { “o poço que } \\
\text { iria mudar os } \\
\text { destinos de } \\
\text { um país, } \\
\text { arrancando-o } \\
\text { da sua eterna } \\
\text { anemia } \\
\text { econômica } \\
\text { para lançá-lo } \\
\text { na larga } \\
\text { Avenida do } \\
\text { Progresso } \\
\text { Sem Fim" } \\
\text { (2010c: 129). }\end{array}$ & $\begin{array}{l}\text { “A ciência foi } \\
\text { nascendo, e o } \\
\text { que } \\
\text { chamamos } \\
\text { progresso não } \\
\text { passa de } \\
\text { aplicação da } \\
\text { ciência à vida } \\
\text { do homem } \\
\text { (2014b: 14). }\end{array}$ \\
\hline Civilização & $\begin{array}{l}\text { "A descoberta } \\
\text { do fogo } \\
\text { trouxe logo a } \\
\text { do ferro e foi } \\
\text { do ferro que } \\
\text { saiu toda a } \\
\text { nossa } \\
\text { civilização" } \\
\text { (2015b: } 23) ; \\
\text { "[o Brasil] } \\
\text { também } \\
\text { poderá vir a } \\
\text { ser um } \\
\text { gigante em } \\
\text { civilização" } \\
\text { (2015b: 271). }\end{array}$ & $\begin{array}{l}\text { "Mas } \\
\text { roubaram } \\
\text { mesmo, em } \\
\text { nome do que } \\
\text { eles chamam } \\
\text { Civilização" } \\
\text { (2013: 155); } \\
\text { "-Que } \\
\text { horror, vovó! } \\
\text { (...) E quem } \\
\text { fazia isso? } \\
\text { - Todos os } \\
\text { civilizados } \\
\text { (...). Os } \\
\text { civilizados, } \\
\text { então, com } \\
\text { seus navios } \\
\text { negreiros, } \\
\text { vinham pegar }\end{array}$ & $\begin{array}{l}\text { “A civiliza- } \\
\text { ção que temos } \\
\text { hoje, com } \\
\text { suas } \\
\text { locomotivas } \\
\text { poderosís- } \\
\text { simas, seus } \\
\text { automóveis, } \\
\text { seus navios } \\
\text { gigantescos, } \\
\text { suas fábricas } \\
\text { de tudo } \\
\text { quanto } \\
\text { existe” } \\
\text { (2017a: 40-1). }\end{array}$ & $\begin{array}{l}\text { "Logo que } \\
\text { aqui cheguei } \\
\text { meu queixo } \\
\text { caiu; (...) ao } \\
\text { reconhecer } \\
\text { nele um sábio } \\
\text { - mas sábio } \\
\text { de verdade, } \\
\text { desses que } \\
\text { descobrem } \\
\text { coisas e } \\
\text { mudam as } \\
\text { diretrizes da } \\
\text { civilização" } \\
\text { (2010c: 110). }\end{array}$ & $\begin{array}{l}\text { "O ferro (...) é } \\
\text { a matéria } \\
\text { fundamental } \\
\text { da civilização } \\
\text { (...) e é da } \\
\text { máquina [de } \\
\text { ferro] que } \\
\text { vem o } \\
\text { progresso, a } \\
\text { riqueza, a } \\
\text { civilização" } \\
\text { (2014b: 178). }\end{array}$ \\
\hline
\end{tabular}




\begin{tabular}{|c|c|c|c|c|c|}
\hline & & $\begin{array}{l}\text { o carrega- } \\
\text { mento" } \\
(2013: 187) .\end{array}$ & & & \\
\hline $\begin{array}{l}\text { Resistência } \\
\text { dos homens } \\
\text { médios ao } \\
\text { progresso e a } \\
\text { descobertas e } \\
\text { mudanças }\end{array}$ & $\begin{array}{l}\text { "A hu- } \\
\text { manidade, } \\
\text { entretanto, é } \\
\text { volúvel. Logo } \\
\text { apareceram } \\
\text { murmura- } \\
\text { dores } \\
\text { procurando } \\
\text { diminuir o } \\
\text { alcance da } \\
\text { sua desco- } \\
\text { berta" } \\
\text { (2015b: 233); } \\
\text { "As correntes } \\
\text { que teve no } \\
\text { pulso } \\
\text { Colombo as } \\
\text { guardou por } \\
\text { muito tempo } \\
\text { em sua casa, } \\
\text { como } \\
\text { memória da } \\
\text { maldade e } \\
\text { ingratidão dos } \\
\text { homens" } \\
\text { (2015b: } 234 \text { ). }\end{array}$ & $\begin{array}{l}\text { "O homem é } \\
\text { um bicho } \\
\text { estúpido. } \\
\text { Quando uma } \\
\text { ideia lhe é } \\
\text { embutida na } \\
\text { cabeça } \\
\text { durante muito } \\
\text { tempo, nem } \\
\text { com boticão } \\
\text { de dentista é } \\
\text { possível } \\
\text { arrancá-la" } \\
\text { (2013: 177). }\end{array}$ & $\begin{array}{l}\text { "O homem } \\
\text { acostuma-se } \\
\text { ao que tem e } \\
\text { refuga as } \\
\text { novidades } \\
\text { que } \\
\text { apresentam } \\
\text { progresso. } \\
\text { Tolice, } \\
\text { porque as } \\
\text { novidades } \\
\text { acabam } \\
\text { sempre } \\
\text { vitoriosas e ai } \\
\text { do mundo se } \\
\text { não fosse } \\
\text { assim!...” } \\
\text { (2017a: 42). }\end{array}$ & $\begin{array}{l}\text { "Sim, o } \\
\text { petróleo } \\
\text { começava a } \\
\text { mudar tudo, } \\
\text { não havia } \\
\text { dúvida. Os } \\
\text { velhos } \\
\text { conhecimen- } \\
\text { tos, os velhos } \\
\text { hábitos, as } \\
\text { velhas } \\
\text { tradições - } \\
\text { tudo isso } \\
\text { tinha de } \\
\text { desaparecer } \\
\text { diante da } \\
\text { americaniza- } \\
\text { ção que a } \\
\text { indústria traz. } \\
\text { E Dona Benta } \\
\text { sentiu uma } \\
\text { ponta de } \\
\text { saudade do } \\
\text { sossego } \\
\text { antigo" } \\
\text { (2010c: 147). }\end{array}$ & $\begin{array}{l}\text { "Quando leio } \\
\text { arengas } \\
\text { contra a } \\
\text { máquina, } \\
\text { lembro-me de } \\
\text { uma sova de } \\
\text { pau que } \\
\text { Narizinho deu } \\
\text { numa cadeira } \\
\text { certo dia. (...) } \\
\text { Atribuir } \\
\text { males à } \\
\text { máquina é } \\
\text { surrar } \\
\text { cadeira" } \\
\text { (2014b: } 80) .\end{array}$ \\
\hline $\begin{array}{l}\text { Uso da } \\
\text { tecnologia de } \\
\text { acordo com } \\
\text { as intenções } \\
\text { e práticas } \\
\text { humanas }\end{array}$ & $\begin{array}{l}\text { "Depois da } \\
\text { tomada de } \\
\text { Constantino- } \\
\text { pla todas as } \\
\text { grandes } \\
\text { matanças de } \\
\text { gente, ou } \\
\text { guerras, } \\
\text { foram feitas } \\
\text { com pólvora" } \\
\text { (2015b: 227); } \\
\text { "O emprego } \\
\text { das invenções } \\
\text { para a } \\
\text { destruição das } \\
\text { cidades e de } \\
\text { tudo vai num } \\
\text { tal crescendo } \\
\text { que um } \\
\text { escritor } \\
\text { inglês, Wells, } \\
\text { admite o fim } \\
\text { do Homo } \\
\text { sapiens, } \\
\text { vitimado } \\
\text { pelos }\end{array}$ & $\begin{array}{l}\text { "O segredo da } \\
\text { grandeza } \\
\text { americana } \\
\text { está na sua } \\
\text { tremenda } \\
\text { indústria do } \\
\text { ferro e do } \\
\text { combustível. } \\
\text { Com o ferro } \\
\text { fazem toda } \\
\text { sorte de } \\
\text { máquinas } \\
\text { possíveis e } \\
\text { imagináveis - } \\
\text { desde } \\
\text { relógios, } \\
\text { maqui- } \\
\text { nazinhas de } \\
\text { marcar o } \\
\text { tempo, até o } \\
\text { canhão, } \\
\text { máquina de } \\
\text { matar gente. } \\
\text { Máquinas de } \\
\text { tudo - de } \\
\text { fazer papel, }\end{array}$ & $\begin{array}{l}\text { "[As in- } \\
\text { venções } \\
\text { humanas] } \\
\text { Prestam } \\
\text { benefícios } \\
\text { sem nome, } \\
\text { quando bem } \\
\text { empregadas; } \\
\text { e também } \\
\text { causam } \\
\text { horrores sem } \\
\text { nome, se mal } \\
\text { empregadas" } \\
\text { (2017a: 49). }\end{array}$ & $\begin{array}{l}\text { "Colocado } \\
\text { num motor, } \\
\text { esse petróleo } \\
\text { se transforma } \\
\text { em energia } \\
\text { mecânica, a } \\
\text { serviço de } \\
\text { todos os } \\
\text { trabalhos do } \\
\text { homem - para } \\
\text { puxar carros, } \\
\text { para mover } \\
\text { navios ou } \\
\text { aviões, para } \\
\text { levantar pesos } \\
\text { nos guindas- } \\
\text { tes, para } \\
\text { movimentar } \\
\text { as mil } \\
\text { máquinas das } \\
\text { fábricas, para } \\
\text { tudo quanto o } \\
\text { homem faz } \\
\text { com o fogo } \\
\text { ou as } \\
\text { pequeninas }\end{array}$ & $\begin{array}{l}\text { “A máquina } \\
\text { obedece ao } \\
\text { homem, só } \\
\text { faz o que ele } \\
\text { manda. Se de } \\
\text { um avião de } \\
\text { guerra cai } \\
\text { uma bomba } \\
\text { aqui em cima } \\
\text { de nós e nos } \\
\text { mata, que } \\
\text { culpa disso } \\
\text { tem o avião? } \\
\text { Criminoso é o } \\
\text { piloto que } \\
\text { lançou a } \\
\text { bomba” } \\
\text { (2014b: } 80 \text { ). }\end{array}$ \\
\hline
\end{tabular}




\begin{tabular}{|c|c|c|c|c|c|}
\hline & $\begin{array}{l}\text { progressos da } \\
\text { química" } \\
\text { (2015b: 228); } \\
\text { "O que os } \\
\text { Estados } \\
\text { Unidos } \\
\text { fizeram em } \\
\text { matéria de } \\
\text { improvisação } \\
\text { de exércitos, } \\
\text { esquadras e } \\
\text { aviões foi o } \\
\text { assombro dos } \\
\text { povos. Nunca } \\
\text { o mundo viu } \\
\text { um esforço } \\
\text { maior e mais } \\
\text { bem or- } \\
\text { ganizado" } \\
\text { (2015b: } 317 \text { ). }\end{array}$ & $\begin{array}{l}\text { de tecer, de } \\
\text { escrever, de } \\
\text { costurar, de } \\
\text { tudo, tudo, } \\
\text { tudo" (2013: } \\
96) .\end{array}$ & & $\begin{array}{l}\text { explosões dos } \\
\text { gases" } \\
\text { (2010c: 62). }\end{array}$ & \\
\hline $\begin{array}{l}\text { Trabalhado- } \\
\text { res x mecani- } \\
\text { zação }\end{array}$ & $\begin{array}{l}\text { Sem menção } \\
\text { direta. }\end{array}$ & $\begin{array}{l}\text { Sem menção } \\
\text { direta. }\end{array}$ & $\begin{array}{l}\text { "Os inimigos } \\
\text { da máquina } \\
\text { não percebem } \\
\text { que a minha } \\
\text { máquina veio } \\
\text { libertar os } \\
\text { meus atuais } \\
\text { cinco } \\
\text { escravos" } \\
\text { (2017a: 77). }\end{array}$ & $\begin{array}{l}\text { Sem menção } \\
\text { direta. }\end{array}$ & $\begin{array}{l}\text { "Vou falar da } \\
\text { máquina, } \\
\text { essas } \\
\text { maravilhas de } \\
\text { engenho (...) } \\
\text { às quais as } \\
\text { criaturas } \\
\text { estúpidas } \\
\text { atribuem a } \\
\text { crise por que } \\
\text { está passando } \\
\text { o mundo" } \\
\text { (2014b: 80). }\end{array}$ \\
\hline $\begin{array}{l}\text { Homens de } \\
\text { visão }\end{array}$ & $\begin{array}{l}\text { "Estava } \\
\text { Colombo } \\
\text { vitorioso, } \\
\text { graças à sua } \\
\text { inabalável } \\
\text { convicção e } \\
\text { espantosa } \\
\text { tenacidade" } \\
\text { (2015b: 231); } \\
\text { "Hoje o } \\
\text { mundo inteiro } \\
\text { admira } \\
\text { Wagner, e o } \\
\text { considera um } \\
\text { renovador, } \\
\text { isto é, um } \\
\text { homem que } \\
\text { abre } \\
\text { caminhos } \\
\text { novos, ou que } \\
\text { cria coisas } \\
\text { que não }\end{array}$ & $\begin{array}{l}\text { “- Mas } \\
\text { como os } \\
\text { ingleses } \\
\text { conseguiram } \\
\text { isso? Eles são } \\
\text { tão poucos... } \\
\text { — Força do } \\
\text { cérebro, meu } \\
\text { filho. } \\
\text { Previsão, bom } \\
\text { governo, } \\
\text { firmeza de } \\
\text { caráter. Povo } \\
\text { dotado dessas } \\
\text { características } \\
\text { vai longe...” } \\
\text { (2013: 116). }\end{array}$ & $\begin{array}{l}\text { "Em cada } \\
\text { cem criaturas } \\
\text { haverá uma } \\
\text { desse gênero, } \\
\text { de modo que } \\
\text { eles têm } \\
\text { sempre contra } \\
\text { si os } 99 \\
\text { restantes" } \\
\text { (2017a: 96). }\end{array}$ & $\begin{array}{l}\text { "Há lá [em } \\
\text { Alagoas] um } \\
\text { petroleiro } \\
\text { chamado } \\
\text { Edson, e um } \\
\text { governador } \\
\text { de estado, de } \\
\text { nome Osman, } \\
\text { que até mere- } \\
\text { cem estátuas } \\
\text { de ouro!" } \\
\text { (2010c: 79); } \\
\text { "Depois de } \\
\text { ter ganhado } \\
\text { montões (...) } \\
\text { de ouro, ficou } \\
\text { sem saber o } \\
\text { que fazer da- } \\
\text { quilo. E } \\
\text { fundou o } \\
\text { Instituto } \\
\text { Rockefeller, }\end{array}$ & $\begin{array}{l}\text { "Os homens } \\
\text { verda- } \\
\text { deiramente } \\
\text { inteligentes } \\
\text { são pou- } \\
\text { quíssimos - e } \\
\text { os verdadeira- } \\
\text { mente bons, } \\
\text { ainda em } \\
\text { menor } \\
\text { número..." } \\
\text { (2014b: 77). }\end{array}$ \\
\hline
\end{tabular}




\begin{tabular}{|c|c|c|c|c|c|}
\hline & $\begin{array}{l}\text { existiam } \\
\text { antes" } \\
\text { (2015b: 299). }\end{array}$ & & & $\begin{array}{l}\text { cuja função é } \\
\text { gastar seus } \\
\text { milhões em } \\
\text { coisas de } \\
\text { benefício uni- } \\
\text { versal" } \\
\text { (2010c: 93). }\end{array}$ & \\
\hline $\begin{array}{l}\text { Elogio da au- } \\
\text { dácia }\end{array}$ & $\begin{array}{l}\text { "Magalhães, } \\
\text { porém, que } \\
\text { era de ferro, } \\
\text { não arrepiou } \\
\text { caminho. Para } \\
\text { a frente! } \\
\text { Sempre para a } \\
\text { frente!" } \\
\text { (2015b: 239); } \\
\text { "[Lutero] Era } \\
\text { um homem } \\
\text { decidido e } \\
\text { franco. Se } \\
\text { não gostava } \\
\text { de uma coisa, } \\
\text { dizia” } \\
\text { (2015b: 250). }\end{array}$ & $\begin{array}{l}\text { “A riqueza } \\
\text { dos } \\
\text { americanos, } \\
\text { junto à } \\
\text { audácia da } \\
\text { sua iniciativa, } \\
\text { fez que o país } \\
\text { se enchesse } \\
\text { de coisas } \\
\text { únicas, coisas } \\
\text { inéditas no } \\
\text { mundo" } \\
\text { (2013: 94-5). }\end{array}$ & $\begin{array}{l}\text { "Você é o que } \\
\text { é, muito } \\
\text { independente } \\
\text { de ideias, } \\
\text { muito } \\
\text { corajosa. Diz } \\
\text { sempre o que } \\
\text { pensa, sem } \\
\text { escolher } \\
\text { ocasião ou } \\
\text { palavras" } \\
\text { (2017a: 78). }\end{array}$ & $\begin{array}{l}\text { “Já há mais } \\
\text { de novecentos } \\
\text { mil poços (...) } \\
\text { abertos nos } \\
\text { Estados } \\
\text { Unidos. Os } \\
\text { americanos } \\
\text { são umas } \\
\text { feras. E como } \\
\text { fazem tudo } \\
\text { em ponto } \\
\text { grande, } \\
\text { tornaram-se o } \\
\text { povo mais } \\
\text { adiantado e } \\
\text { rico do } \\
\text { mundo" } \\
\text { (2010: 50); } \\
\text { "quem pode } \\
\text { com o bicho- } \\
\text { homem?” } \\
\text { (2010c: } 52 \text { ); } \\
\text { "ou falo como } \\
\text { quero ou me } \\
\text { calo" (2010c: } \\
60) \text {. }\end{array}$ & $\begin{array}{l}\text { "Por isso } \\
\text { gosto dos } \\
\text { americanos. } \\
\text { Só eles têm a } \\
\text { coragem } \\
\text { dessas coisas } \\
\text { loucas" } \\
\text { (2014b: 134). }\end{array}$ \\
\hline $\begin{array}{l}\text { Indústrias } \\
\text { Ford, Henry } \\
\text { Ford }\end{array}$ & $\begin{array}{l}\text { Sem menção } \\
\text { direta. }\end{array}$ & $\begin{array}{l}\text { “Quem hoje } \\
\text { começa a } \\
\text { fazer isso é o } \\
\text { Ford dos } \\
\text { automóveis. } \\
\text { Obteve } \\
\text { grandes } \\
\text { extensões de } \\
\text { terra no Pará } \\
\text { e está for- } \\
\text { mando } \\
\text { cafezais de } \\
\text { seringueiras. } \\
\text { Ford, sim, vai } \\
\text { obter na } \\
\text { Amazônia } \\
\text { boa borracha } \\
\text { pelo mesmo } \\
\text { preço de } \\
\text { custo que os } \\
\text { holandeses e } \\
\text { ingleses }\end{array}$ & $\begin{array}{l}\text { "Sem aquele } \\
\text { rolete que o } \\
\text { fogo queimou } \\
\text { não teríamos } \\
\text { os Fordes e os } \\
\text { aviões" } \\
(2017 \text { a: } 92) .\end{array}$ & $\begin{array}{l}\text { Sem menção } \\
\text { direta. }\end{array}$ & $\begin{array}{l}\text { "Um automó- } \\
\text { vel entalado } \\
\text { só sai à força } \\
\text { de bois, e no } \\
\text { entanto numa } \\
\text { estrada lisa } \\
\text { com uma } \\
\text { ombrada eu } \\
\text { faço um Ford } \\
\text { parado } \\
\text { mover-se" } \\
\text { (2014b: 79). }\end{array}$ \\
\hline
\end{tabular}




\begin{tabular}{|c|c|c|c|c|c|}
\hline & & $\begin{array}{l}\text { conseguem } \\
\text { em suas } \\
\text { colônias" } \\
(2013: 76) .\end{array}$ & & & \\
\hline $\begin{array}{l}\text { Arranha- } \\
\text { céus }\end{array}$ & $\begin{array}{l}\text { Sem menção } \\
\text { direta. }\end{array}$ & $\begin{array}{l}\text { "Muito mais } \\
\text { alta que o Pão } \\
\text { de Açúcar ou } \\
\text { o mais alto } \\
\text { arranha-céu } \\
\text { de Nova York } \\
\text { ou a Torre } \\
\text { Eiffel de } \\
\text { Paris" (2013: } \\
\text { 51); "É a terra } \\
\text { de uma } \\
\text { porção de } \\
\text { coisas que só } \\
\text { há lá, como } \\
\text { os sky-scra- } \\
\text { pers, ou } \\
\text { arranha-céus" } \\
\text { (2013: 94); } \\
\text { "Quando os } \\
\text { gigantescos } \\
\text { arranha-céus } \\
\text { próximos ao } \\
\text { cais começa- } \\
\text { ram a ser } \\
\text { vistos de } \\
\text { perto" (2013: } \\
103) \text {. }\end{array}$ & $\begin{array}{l}\text { "O Empire } \\
\text { State } \\
\text { Building! (...) } \\
\text { O orgulho de } \\
\text { ser homem, } \\
\text { de pertencer à } \\
\text { mesma } \\
\text { espécie dos } \\
\text { que haviam } \\
\text { construído o } \\
\text { colosso..." } \\
(2017 \mathrm{a}: 43) .\end{array}$ & $\begin{array}{l}\text { Sem menção } \\
\text { direta. }\end{array}$ & $\begin{array}{l}\text { "Para } \\
\text { imaginarmos } \\
\text { o que essas } \\
\text { alturas } \\
\text { representam } \\
\text { temos de } \\
\text { refletir que o } \\
\text { edifício mais } \\
\text { alto de São } \\
\text { Paulo, o } \\
\text { Martinelli, } \\
\text { tem apenas } 70 \\
\text { metros; a } \\
\text { torre Eiffel, } \\
\text { em Paris, tem } \\
\text { 300; o Empire } \\
\text { State } \\
\text { Building, em } \\
\text { Nova York, } \\
\text { tem 380" } \\
\text { (2014b: 20). }\end{array}$ \\
\hline $\begin{array}{l}\text { Professor au- } \\
\text { torizado }\end{array}$ & $\begin{array}{l}\text { "Dona Benta } \\
\text { era uma } \\
\text { senhora de } \\
\text { muita leitura; } \\
\text { além de ter } \\
\text { uma } \\
\text { biblioteca de } \\
\text { várias } \\
\text { centenas de } \\
\text { volumes, } \\
\text { ainda recebia, } \\
\text { de um livreiro } \\
\text { da capital, as } \\
\text { novidades } \\
\text { mais in- } \\
\text { teressante do } \\
\text { momento" } \\
\text { (2015b: 14); } \\
\text { "Só vovó } \\
\text { sabe, Pedri- } \\
\text { nho! Vovó é } \\
\text { um colosso! } \\
\text { Não há o que } \\
\text { não saiba" }\end{array}$ & $\begin{array}{l}\text { “- Deixe } \\
\text { vovó explicar, } \\
\text { Emília. A } \\
\text { professora é } \\
\text { ela, não você" } \\
\text { (2013: } 31) ; \\
\text { "Dona Benta } \\
\text { calou-se por } \\
\text { uns instantes, } \\
\text { pensativa. Era } \\
\text { uma danada } \\
\text { de estudiosa, } \\
\text { aquela velhi- } \\
\text { nha” (2013: } \\
\text { 151); } \\
\text { "Correram a } \\
\text { cidade inteira } \\
\text { de automóvel, } \\
\text { ouvindo as } \\
\text { explicações } \\
\text { da velha, que } \\
\text { parecia ter } \\
\text { vivido toda a }\end{array}$ & $\begin{array}{l}\text { "Este livro } \\
\text { não é para } \\
\text { crianças (...), } \\
\text { mas se eu o } \\
\text { ler do meu } \\
\text { modo vocês } \\
\text { entenderão } \\
\text { tudo" (2017a: } \\
\text { 12). }\end{array}$ & $\begin{array}{l}\text { "Continuo a } \\
\text { aprovar a } \\
\text { ciência do } \\
\text { Visconde. } \\
\text { Tudo quanto } \\
\text { ele disse está } \\
\text { de acordo } \\
\text { com o que os } \\
\text { geólogos } \\
\text { ensinam. Ele } \\
\text { é um sábio de } \\
\text { verdade” } \\
\text { (2010c: 42- } \\
\text { 3); “Acho que } \\
\text { o Senhor } \\
\text { Visconde de } \\
\text { Sabugosa do } \\
\text { Poço Fundo } \\
\text { (...) é na reali- } \\
\text { dade um } \\
\text { grande sábio. } \\
\text { (...) O Vis- } \\
\text { conde, minha } \\
\text { senhora, }\end{array}$ & $\begin{array}{l}\text { "Tudo quanto } \\
\text { sei me foi } \\
\text { ensinado por } \\
\text { vovó, durante } \\
\text { as férias que } \\
\text { passo aqui. } \\
\text { Só vovó sabe } \\
\text { ensinar. Não } \\
\text { caceteia, não } \\
\text { diz coisas que } \\
\text { não entendo" } \\
\text { (2014b: 184). }\end{array}$ \\
\hline
\end{tabular}




\begin{tabular}{|c|c|c|c|c|c|}
\hline & $\begin{array}{l}\text { (2015b: 142); } \\
\text { "No dia } \\
\text { seguinte } \\
\text { Dona Benta } \\
\text { recebeu um } \\
\text { pacote de } \\
\text { livros } \\
\text { ingleses" } \\
\text { (2015b: 177). }\end{array}$ & $\begin{array}{l}\text { vida lá" } \\
(2013: 215) .\end{array}$ & & $\begin{array}{l}\text { ainda há de } \\
\text { assombrar o } \\
\text { mundo" } \\
\text { (2010c: 110). }\end{array}$ & \\
\hline $\begin{array}{l}\text { Retórica, } \\
\text { métodos e } \\
\text { resultados do } \\
\text { professor }\end{array}$ & $\begin{array}{l}\text { "Uma criança } \\
\text { não tem culpa } \\
\text { de não saber, } \\
\text { e para que } \\
\text { saiba uma } \\
\text { porção de } \\
\text { coisas úteis é } \\
\text { que as vovós } \\
\text { contam estas } \\
\text { histórias do } \\
\text { mundo" } \\
\text { (2015b: 191). }\end{array}$ & $\begin{array}{l}\text { “_ Todas as } \\
\text { coisas da } \\
\text { ciência são } \\
\text { simples } \\
\text { quanto as } \\
\text { entendemos. } \\
\text { — Sempre } \\
\text { que a senhora } \\
\text { explica, nós } \\
\text { entendemos } \\
\text { muito bem; } \\
\text { mas quando } \\
\text { os outros } \\
\text { explicam, } \\
\text { ficamos na } \\
\text { mesma. } \\
\text { - É que só } \\
\text { explico o que } \\
\text { sei. Muitas } \\
\text { criaturas se } \\
\text { metem a } \\
\text { explicar o que } \\
\text { não sabem -e } \\
\text { por isso } \\
\text { ninguém as } \\
\text { entende" } \\
\text { (2013: } 14 \text { ). }\end{array}$ & $\begin{array}{l}\text { "Não há o } \\
\text { que a gente } \\
\text { não } \\
\text { compreenda } \\
\text { quando a } \\
\text { senhora } \\
\text { explica, } \\
\text { vovó" } \\
(2017 \mathrm{a}: 46) \text {. }\end{array}$ & $\begin{array}{l}\text { "Meu curso } \\
\text { não é para } \\
\text { formar } \\
\text { especialistas, } \\
\text { e sim para dar } \\
\text { uma ideia } \\
\text { geral da } \\
\text { coisa" } \\
\text { (2010c: 39); } \\
\text { "Vamos } \\
\text { começar o } \\
\text { trabalho e o } \\
\text { Visconde nos } \\
\text { vai } \\
\text { ensinando. } \\
\text { Lições ao ar } \\
\text { livre - } \\
\text { fazendo. É } \\
\text { fazendo que o } \\
\text { homem } \\
\text { aprende, não } \\
\text { é lendo, nem } \\
\text { ouvindo } \\
\text { discursos. Eu } \\
\text { quero ciência } \\
\text { aplicada..." } \\
\text { (2010c: } 67) \text {. }\end{array}$ & $\begin{array}{l}\text { "A ciência de } \\
\text { que gosto é a } \\
\text { falada, a } \\
\text { contada pela } \\
\text { senhora, } \\
\text { clarinha como } \\
\text { água do pote, } \\
\text { com explica- } \\
\text { ções de tudo } \\
\text { quanto a } \\
\text { gente não } \\
\text { sabe, pensa } \\
\text { que sabe, ou } \\
\text { sabe mal e } \\
\text { mal" (2014b: } \\
\text { 12). }\end{array}$ \\
\hline $\begin{array}{l}\text { Crítica ao } \\
\text { militarismo }\end{array}$ & $\begin{array}{l}\text { "A guerra é } \\
\text { cem vezes } \\
\text { pior [que a } \\
\text { peste]" } \\
\text { (2015b: 100); } \\
\text { "Defesa } \\
\text { própria e } \\
\text { conquista: } \\
\text { essas duas } \\
\text { expressões } \\
\text { justificam a } \\
\text { guerra. } \\
\text { - E acha a } \\
\text { senhora que a } \\
\text { guerra se } \\
\text { justifica, } \\
\text { vovó? } \\
\text { — Para mim } \\
\text { não justifica. }\end{array}$ & $\begin{array}{l}\text { "Dona Benta, } \\
\text { que não } \\
\text { perdia vasa, } \\
\text { meteu o pau } \\
\text { na guerra, e a } \\
\text { propósito da } \\
\text { horrenda } \\
\text { Guerra } \\
\text { Mundial, } \\
\text { nascida em } \\
\text { consequência } \\
\text { do crime de } \\
\text { Sarajevo, } \\
\text { disse: '-Foi } \\
\text { a maior } \\
\text { hecatombe da } \\
\text { História, } \\
\text { meus filhos. } \\
\text { Calcula-se em }\end{array}$ & $\begin{array}{l}\text { "As Grandes } \\
\text { Potências (...) } \\
\text { acabarão } \\
\text { vitimadas } \\
\text { pelo excesso } \\
\text { de arma- } \\
\text { mentos" } \\
(2017 \mathrm{a}: 18) .\end{array}$ & $\begin{array}{l}\text { Sem menção } \\
\text { direta. } \\
\text { Aviões, } \\
\text { tanques, } \\
\text { navios e } \\
\text { outros } \\
\text { "objetos de } \\
\text { guerra" são } \\
\text { referenciados } \\
\text { apenas } \\
\text { positivamen- } \\
\text { te, como } \\
\text { produtos que } \\
\text { o petróleo } \\
\text { proporciona } \\
\text { de um modo } \\
\text { ou de outro. }\end{array}$ & $\begin{array}{l}\text { "Se fosse na } \\
\text { Europa, todo } \\
\text { esse dinheiro } \\
\text { iria para } \\
\text { novos } \\
\text { canhões ou } \\
\text { aviões de } \\
\text { bombar- } \\
\text { deio..." } \\
(2014 \text { b: 134). }\end{array}$ \\
\hline
\end{tabular}




\begin{tabular}{|c|c|c|c|c|c|}
\hline & $\begin{array}{l}\text { Para Jesus } \\
\text { Cristo } \\
\text { também não } \\
\text { se justificava” } \\
\text { (2015b: 217); } \\
\text { “- Que } \\
\text { tristeza o } \\
\text { nosso mundo, } \\
\text { vovó! } \\
\text { — disse a } \\
\text { menina. Só a } \\
\text { guerra tem } \\
\text { importância e } \\
\text { só são } \\
\text { grandes os } \\
\text { países e os } \\
\text { homens que } \\
\text { fazem } \\
\text { guerra... os } \\
\text { que } \\
\text { destroem... os } \\
\text { que matam...” } \\
\text { (2015b: } 303 \text { ). }\end{array}$ & $\begin{array}{l}40 \text { milhões o } \\
\text { número das } \\
\text { vítimas, entre } \\
\text { mortos, } \\
\text { feridos e } \\
\text { inutilizados } \\
\text { para sempre } \\
\text { (...) E a } \\
\text { humanidade é } \\
\text { tão estúpida } \\
\text { que continua } \\
\text { a adorar os } \\
\text { guerreiros e a } \\
\text { entusiasmar- } \\
\text { se pelos } \\
\text { estadistas que } \\
\text { arrastam seus } \\
\text { países à } \\
\text { guerra...” } \\
\text { (2013: 179). }\end{array}$ & & & \\
\hline $\begin{array}{l}\text { Experiências } \\
\text { de Lobato } \\
\text { nos EUA }\end{array}$ & $\begin{array}{l}\text { Alusões e } \\
\text { referências } \\
\text { pontuais aos } \\
\text { Estados } \\
\text { Unidos: "Nos } \\
\text { Estados } \\
\text { Unidos há } \\
\text { uma impor- } \\
\text { tante cidade } \\
\text { do Estado de } \\
\text { Ohio que se } \\
\text { chama } \\
\text { Cincinnati" } \\
\text { (2015b: 86); } \\
\text { "Tal como } \\
\text { hoje ser } \\
\text { cidadão } \\
\text { americano ou } \\
\text { inglês [é uma } \\
\text { honra e } \\
\text { garantia]" } \\
\text { (2015b: 118); } \\
\text { "Lincoln e } \\
\text { Washington } \\
\text { são os dois } \\
\text { semideuses } \\
\text { do povo } \\
\text { norte- } \\
\text { americano" } \\
\text { (2015b: 305). }\end{array}$ & $\begin{array}{l}\text { "Por que (...) } \\
\text { não cons- } \\
\text { troem canali- } \\
\text { zações como } \\
\text { aquela que a } \\
\text { senhora nos } \\
\text { mostrou nos } \\
\text { Estados } \\
\text { Unidos para } \\
\text { irrigar as } \\
\text { terras secas } \\
\text { da Califór- } \\
\text { nia?" (2013: } \\
\text { 67). } \\
\\
\text { O livro tem } \\
\text { uma curiosa e } \\
\text { irreverente } \\
\text { seção (em } \\
\text { dois ca- } \\
\text { pítulos) } \\
\text { dedicada aos } \\
\text { EUA e sua } \\
\text { cultura, com } \\
\text { brincadeiras } \\
\text { sobre cinema } \\
\text { e o sistema de } \\
\text { celebridades. }\end{array}$ & $\begin{array}{l}\text { "Lembrou } \\
\text { Pedrinho, que } \\
\text { havia visto } \\
\text { em Nova } \\
\text { York e } \\
\text { Londres os } \\
\text { chamados } \\
\text { tenements, ou } \\
\text { casas de } \\
\text { apartamentos } \\
\text { dos pobres" } \\
\text { (2017a: } 38) \text {. }\end{array}$ & $\begin{array}{l}\text { O livro é } \\
\text { permeado de } \\
\text { explicações, } \\
\text { métodos e } \\
\text { sistemas } \\
\text { referentes a } \\
\text { petróleo que } \\
\text { Lobato } \\
\text { conheceu em } \\
\text { sua passagem } \\
\text { pelos EUA. } \\
\text { Complementa } \\
\text { e atualiza } \\
\text { informações } \\
\text { de } O \\
\text { escândalo do } \\
\text { petróleo. } \\
\text { Notam-se, } \\
\text { ainda, } \\
\text { espalhadas } \\
\text { pelo livro, } \\
\text { menções } \\
\text { como a certos } \\
\text { "hospitais } \\
\text { americanos" } \\
\text { (2010c: 165). }\end{array}$ & $\begin{array}{l}\text { "Cada ano os } \\
\text { Estados } \\
\text { Unidos } \\
\text { extraem do } \\
\text { seu subsolo } \\
\text { riquezas no } \\
\text { valor de } 100 \\
\text { milhões de } \\
\text { contos. } \\
\text { Infelizmente } \\
\text { cá no Brasil } \\
\text { ainda não nos } \\
\text { voltamos para } \\
\text { o subsolo" } \\
\text { (2014b: 180). }\end{array}$ \\
\hline
\end{tabular}




\begin{tabular}{|c|c|c|c|c|c|}
\hline $\begin{array}{l}\text { Críticas de } \\
\text { Lobato aos } \\
\text { EUA }\end{array}$ & $\begin{array}{l}\text { O último } \\
\text { capítulo do } \\
\text { livro é um } \\
\text { lamento pela } \\
\text { imaturidade } \\
\text { das nações e a } \\
\text { onipresença } \\
\text { das guerras na } \\
\text { história da } \\
\text { Humanidade. } \\
\text { Intitula-se } \\
\text { Hiroshima e, } \\
\text { apesar de não } \\
\text { falar que a } \\
\text { bomba contra } \\
\text { Hiroshima (e } \\
\text { Nagasaki) foi } \\
\text { mandada } \\
\text { pelos Estados } \\
\text { Unidos, o } \\
\text { texto é seco } \\
\text { na conde- } \\
\text { nação: "E eu } \\
\text { não me } \\
\text { espantarei de } \\
\text { que a data da } \\
\text { destruição da } \\
\text { cidade de Hi- } \\
\text { roshima, no } \\
\text { Japão, vítima } \\
\text { da primeira } \\
\text { bomba } \\
\text { atômica, } \\
\text { venha a } \\
\text { marcar o co- } \\
\text { meço da } \\
\text { IDADE } \\
\text { ATÔMICA. } \\
\text { (...) } \\
\text { - E com } \\
\text { certeza } \\
\text { teremos } \\
\text { também } \\
\text { guerras } \\
\text { atômicas, } \\
\text { vovó. A } \\
\text { História é só } \\
\text { guerras, } \\
\text { guerras e } \\
\text { mais guerras" } \\
\text { (2015b: } 318 \text { ). }\end{array}$ & $\begin{array}{l}\text { “quero desde } \\
\text { já prevenir } \\
\text { vocês sobre } \\
\text { esse costume } \\
\text { do povo - a } \\
\text { mascação do } \\
\text { chewing gum. } \\
\text { É um mau } \\
\text { costume } \\
\text { mexicano } \\
\text { adotado pelos } \\
\text { americanos" } \\
\text { (2013: 100- } \\
\text { 1); "roubam } \\
\text { seus tesouros, } \\
\text { como os } \\
\text { franceses, } \\
\text { ingleses, } \\
\text { alemães, } \\
\text { americanos e } \\
\text { italianos } \\
\text { fizeram em } \\
\text { 1901” (2013: } \\
\text { 149); "Um } \\
\text { bando de } \\
\text { Elias Turcos, } \\
\text { armados até } \\
\text { os dentes, os } \\
\text { tais franceses, } \\
\text { ingleses, ale- } \\
\text { mães, ameri- } \\
\text { canos e italia- } \\
\text { nos, reunidos } \\
\text { com o } \\
\text { pretexto de } \\
\text { vingar } \\
\text { ofensas, aqui } \\
\text { entraram à } \\
\text { força em } \\
\text { 1901 e } \\
\text { roubaram os } \\
\text { mais ricos } \\
\text { tesouros da } \\
\text { China” (2013: } \\
\text { 155). }\end{array}$ & $\begin{array}{l}\text { “Até hoje, e } \\
\text { em países dos } \\
\text { mais } \\
\text { adiantados, } \\
\text { esse cruel } \\
\text { meio de dar } \\
\text { morte às } \\
\text { criaturas } \\
\text { [forca] ainda } \\
\text { subsiste" } \\
\text { (2017a: 64). }\end{array}$ & $\begin{array}{l}\text { “- Vovó, eu } \\
\text { acho uma } \\
\text { grande falta } \\
\text { de educação } \\
\text { essa mania } \\
\text { que Pedrinho } \\
\text { pegou dos } \\
\text { americanos } \\
\text { de sentar-se } \\
\text { com os pés na } \\
\text { cara da gente" } \\
\text { (2010c: 12); } \\
\text { críticas } \\
\text { generalizadas } \\
\text { e imprecisas } \\
\text { sobre trustes, } \\
\text { monopólios e } \\
\text { espionagem } \\
\text { industrial: } \\
\text { "No negócio } \\
\text { do petróleo } \\
\text { dão-se } \\
\text { traições } \\
\text { tremendas, } \\
\text { sabotagens, } \\
\text { incêndios, } \\
\text { mortes } \\
\text { trágicas...” } \\
\text { (2010c: 96) - } \\
\text { as duas } \\
\text { principais } \\
\text { personagens } \\
\text { americanas, } \\
\text { Mister } \\
\text { Kalamazoo e } \\
\text { Mister } \\
\text { Champigon, } \\
\text { são ex- } \\
\text { sabotadores, } \\
\text { redimidos - } \\
\text { ainda que } \\
\text { referenciados } \\
\text { sempre por } \\
\text { sua extrema } \\
\text { competência. }\end{array}$ & $\begin{array}{l}\text { As críticas se } \\
\text { concentram } \\
\text { no Brasil, na } \\
\text { Europa mi- } \\
\text { litarista e na } \\
\text { Guerra da Es- } \\
\text { panha. Lobato } \\
\text { alude a } \\
\text { problemas } \\
\text { naturais dos } \\
\text { EUA } \\
\text { (incêndios, } \\
\text { tornados, } \\
\text { furacões) e } \\
\text { aos altos } \\
\text { custos da } \\
\text { produção } \\
\text { energética } \\
\text { (carvão, } \\
\text { petróleo) e } \\
\text { mineração } \\
\text { (sobretudo } \\
\text { rádio). }\end{array}$ \\
\hline $\begin{array}{l}\text { Menções } \\
\text { culturais }\end{array}$ & $\begin{array}{l}\text { Além de } \\
\text { citações } \\
\text { relacionadas } \\
\text { aos temas } \\
\text { expostos, }\end{array}$ & $\begin{array}{l}\text { Inúmeras } \\
\text { referências e } \\
\text { sugestões ao } \\
\text { longo das } \\
\text { viagens, entre }\end{array}$ & $\begin{array}{l}\text { "Nem os } \\
\text { vestidos } \\
\text { magníficos da } \\
\text { Gloria } \\
\text { Swanson em }\end{array}$ & $\begin{array}{l}\text { "Aquele livro } \\
\text { que estou } \\
\text { lendo, Man } \\
\text { the unkown, } \\
\text { foi escrito por }\end{array}$ & $\begin{array}{l}\text { "Um dia, } \\
\text { quando você } \\
\text { chegar à } \\
\text { minha idade, } \\
\text { saberá o que é }\end{array}$ \\
\hline
\end{tabular}




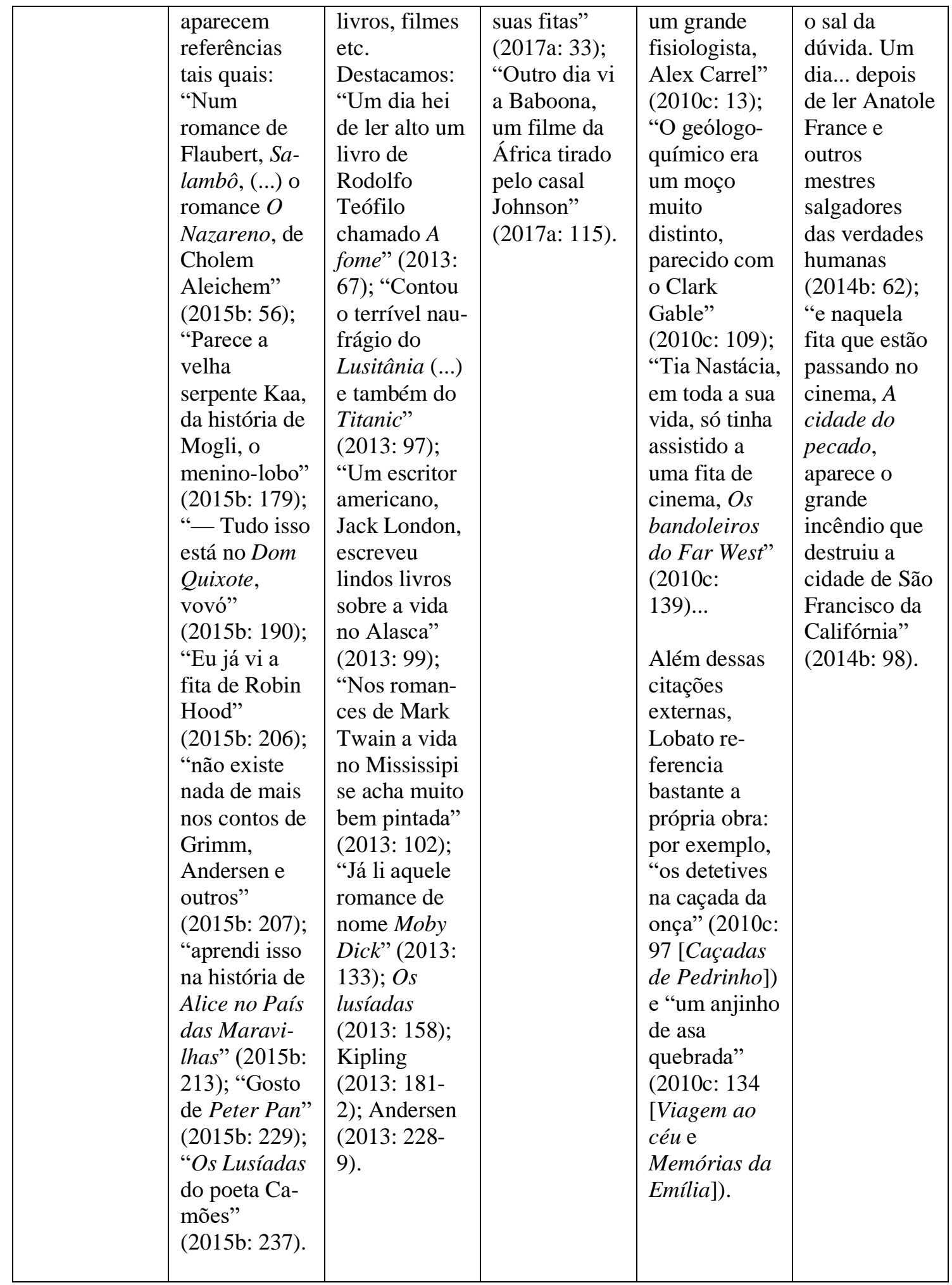




\section{ANEXO 2. LOBATO, MÁRIO DE ANDRADE E O MODERNISMO: TENSÕES EM DIÁLOGO VIA CARTAS}

A relação entre Monteiro Lobato e as forças intelectuais e artísticas da primeira metade do século XX é um importante capítulo de sua biografia e auxilia no adequado dimensionamento das características que o destacaram em seus vários campos de atuação: editorial, expressivo-literário, político. O pequeno artigo que segue foi escrito para uma disciplina de pós-graduação intitulada "A correspondência de Mário de Andrade como 'arquivo da criação' literária”, ministrada por Marcos Antonio de Moraes na USP, ao longo do segundo semestre de 2017. Por ser relevante para a contextualização apresentada em nosso capítulo 2, o texto segue transcrito; por não ser crucial ao tema do trabalho, é apresentado sob a forma de anexo.

Para entender, em certa medida, a produção literário-artística de Monteiro Lobato, é preciso dimensionar o jogo de tensões que se dava entre ele e seus coetâneos colegas do modernismo. Lobato, de modo geral, não era bem visto pelos modernistas, e as razões eram várias: a recusa de Lobato a se filiar a correntes, o sucesso editorial de seus livros e decorrentes acusações de "comercialidade" excessiva, seu pensamento estético apontado como conservador e reacionário, rusgas com alguns dos principais expoentes modernistas.

Nos anos finais da década de 1910, já famoso como crítico de arte do jornal paulistano O Estado de S. Paulo, Lobato causava irritação nos principais difusores do que seria futuramente tido como o movimento modernista. A intelectualidade que já despontava com novas vozes proeminentes no cenário sociocultural brasileiro não esperou chance melhor para desacreditá-lo que quando Lobato publica, em 1917, um artigo sobre uma exposição de Anita Malfatti, conhecido como Paranoia ou mistificação?. Como observa agudamente Tadeu Chiarelli, "toda a responsabilidade pelos novos rumos dados por Anita Malfatti à sua obra foi imputada a alguém que estava completamente fora do movimento", o que "chama a atenção para a importância que Monteiro Lobato (...) possuía no campo da arte paulistana do período" (2008: 72).

A relação de Lobato com os principais núcleos modernistas era, não obstante, complexa. Pouco se comenta que Anita chegaria a trabalhar como capista para a editora de Lobato em anos futuros, por exemplo. Do mesmo modo, Lobato publicou Menotti del Picchia e Oswald de Andrade, conhecidíssimos modernistas. Marcos Antonio de Moraes 
aponta que a Monteiro Lobato \& Cia Editores, então o selo editorial lobatiano, lidou com alguns contatos de modernistas num primeiro momento e esclarece que Oswald "se encarregara de levar os manuscritos de Paulicéia desvairada (...) a Lobato. Caberia ao editor, estupefato diante dos poemas, a exigência de uma explicação inicial no livro, à qual MA responde prontamente com o 'Prefácio interessantíssimo'” (2001: 95). Como resta dito, mesmo assim (ou talvez por isso) Lobato não publica Mário.

O lado de Lobato frente aos "postulados" modernistas deve ser analisado. Pensando no aspecto comercial e publicitário da coisa, não é de admirar a recusa do empreendedor em publicar obras sem apelo de vendagem, como muitas vezes o eram, com inconfessado orgulho, os livros modernistas. Verifiquemos que a Anita-capista é já uma Anita mais "comportada", figurativizada ou mexendo com símbolos e alegorias e não abstrações e deformações que poderiam espantar o leitor visado por Lobato. Sua reorientação pictórica talvez viesse ao encontro dos ideais lobatianos.

Mas provavelmente a relação que mais desvela facetas desse tempo e suas especificidades é a que se estabeleceu entre Lobato e Mário de Andrade. Na década de 1920, Lobato e Mário possuíam um rol impressionante de similitudes. Para começar, ambos, paulistas e nascidos em fins do século XIX, já não eram moços, ainda que não velhos. A década anterior vira o despontar de suas produções literárias editadas: Lobato publica O Saci-Pererê: Resultado de um inquérito e Mário, Há uma gota de sangue em cada poema. São começos que em certa medida denotam temas, assuntos e motivos caros aos autores: folclore rural para Lobato, poesia combativa para Mário - ainda que não em sua forma literária mais acabada, pois obras imaturas. Também a origem peculiar: Lobato viera do jornalismo, Mário, da música.

Os dois autores davam assim seus primeiros passos no mercado editorial, ainda timidamente, com subterfúgios tais como pseudônimos - Lobato assinou produções como Hélio Bruma, um seu alegado amigo de infância, Mário lançou seu primeiro livro como Mário Sobral. Do mesmo modo, suas vidas e carreiras seriam marcadas pelas obras seguintes: Urupês, de Lobato, veio à luz em 1918 e se tornou um marco editorial - João Luís Ceccantini o chama de "o primeiro best-seller brasileiro" (2014: 43) -; Pauliceia desvairada, de 1922, é um divisor de águas na história do modernismo brasileiro.

No entanto, diferentes posicionamentos ideológico-literários, por assim dizer, afastavam um do outro de maneira patente. Lobato é ainda hoje considerado por muitos um ilustre representante do limiar da geração pré-modernista. Alfredo Bosi enxerga nele uma tendência "moralista e didática [que] afastava-o do Modernismo de 22, ou ao menos 
das correntes irracionalistas que lhe permeavam a estética" (1975: 241). Os modernistas, então, considerariam Lobato muito "primitivo" para ser bem-vindo nas vanguardas que surgiam.

A relação de Lobato com Mário é, mesmo nesse contexto, tortuosa. Como dito, sabe-se que Mário ofereceu Pauliceia desvairada para publicação a Lobato. Assumidamente um não cultor da poesia, Lobato apressa-se em rejeitar a demanda, com uma educada mas inflexível recusa. Não era um problema pessoal com Mário, mas uma postulação de princípios: ao longo de sua vida editorial, Lobato se envolveu pouquíssimas vezes com poesia. Manuel Bandeira reporta, em carta a Mário, que Lobato "diz que verso não é negócio, é negocinho. Que isso de versos é bucha, sejam péssimos ou excelentes" (2001: 94).

Lobato, adido comercial nos Estados Unidos entre 1927 e 1931, mora durante esse período em Nova Iorque. De lá, em 1930, manda uma curiosa comunicação a Mário de Andrade, encontrada, datilografada, na documentação de seu fundo no CEDAE - Centro de Documentação Cultural Alexandre Eulalio, do Instituto de Estudos da Linguagem da Unicamp. Abaixo a missiva se encontra transcrita na íntegra, com a ortografia original:

New York, 6 agosto, 930

Meu caro Mario de Andrade,

Muito ha de voce de espantar-se com esta, vinda dalem tumulo, dum morto que voce matou ha tres anos atraz. Mas ha de tudo na vida, até os mortos que escrevem cartas aos matadores.

O que me traz é um livro seu - Macunaíma. Tenho cá um editor que deseja conhececel-o, com palpite que é coisa editavel em inglez. Se voce está por isso, mande-me um exemplar e se achar que um morto pode representar um vivíssimo, mande tambem autorização para eu tratar com o homem.

É incrível como dá voltas o mundo! Vou eu ajudar o Mario a publicar-se neste paiz e ajudar na traducção. Vou sahir da cova só para isso. Depois recolherei de novo, porque não existir é a delícia das delícias, caro Mario.

Hurry up. Manda logo dois exemplares e depressa.

$$
\text { Do seu matado }
$$

\section{Lobato}

Monteiro Lobato

3505 Broadway, New York City ${ }^{78}$

\footnotetext{
${ }^{78}$ MLb 3.1.00169 CX 3 (CEDAE/IEL)
} 
Nota-se que o pensamento editorial, e talvez a honestidade "corporativa" entre escritores, para Lobato, parece ser mais importante que desavenças passageiras. Se um colega da pena é solicitado e ele pode ajudar em sua carreira, ainda que não compartilhe de suas ideias ou aprove sua abordagem estética (não se sabe ao certo o que Lobato pensava de Macunaíma, ou se chegou a lê-lo), Lobato retomará as relações e oferecerá auxílio.

Mário, receoso mas compreensivelmente interessado, pede aconselhamento a seu mais frequente amigo, Manuel Bandeira. Bandeira já havia se indisposto com Lobato quando a promessa de publicação de um seu livro pelo editor paulista não vingou. $O$ poeta pernambucano não o perdoou pelo resto de suas vidas. Ainda assim, Bandeira diz que teve "boa impressão" do convite que Lobato fez a Mário e detalha: "o que ele fez comigo e que creio foi o mesmo que fez com você, não é coisa que impeça reatamento de relações não-íntimas como esta. (...) Não haverá nenhuma quebra de orgulho em aceitar entendimento com ele" (2001: 460).

A resposta de Mário demora apenas algumas semanas. Verifiquemo-la, também transcrita do mesmo fundo e com sua ortografia original:

\section{S. Paulo, 31 - VIII- 930}

Monteiro Lobato,

recebi sua carta e aqui lhe mando os dois exemplares pedidos de "Macunaíma".Está claro que uma proposta de tradução pro inglês só pode ser agradavel pra um literato do Brasil. E não sou diferente dos outros, apesar de ser uma especie de edição especial, irredutivelmente fóra de mercado. Mas devo lhe confessar que vejo muito dificilmente um "Macunaíma" em inglês, ou outra língua qualquer. Careceria tirar muita coisa, e mais transportar que traduzir. Isso mesmo já falei ao pai duma senhorita Margaret Richardson que se propôs a traduzir o livro. Talvez você a conheça pois ela aí vive (The Barbizon, 63rd Lexington Ave.New York City) pensando em traduzir obras brasileiras. Nunca mais recebi notícia nem dela nem do pai e creio que ela desistiu. Não competia a mim insistir, tanto mais que as propostas de contrato eram por tal forma angustiosas que me deixavam muito frio. Dêsse geito prefiro ficar no Brasil que é mais quentinho. Não tenho ambições de ganhar dinheiro com literatura ou literatice, mas é sempre desagradavel a gente se sentir bobizado pelos outros. Caso o editor a que você se refere se confirme em traduzir o livro, você me fará o favor de comunicar a proposta dele. Si êle quiser, que me faça tambem de bobo, não me importo, porém que trate de salvar as aparencias, tão suavisantes e satisfatorias pra quem, como eu, vive sonhando com uma civilisação que acabasse de novo com o conceito de dinheiro.

No mais, seu vingado morto-vivo, viva feliz aí no comercinho de Nova York, como e quanto quiser. Porém nada neste mundo me impede de desejar você morrendo de fome nestes brasis, vivendo de 
expedientes, xingando de canalha e pra baixo o Washington e o Prestes, e dando pro Brasil uns novos "Urupês". Cordialmente o

$$
\begin{gathered}
\text { Mário de Andrade } \\
\text { Rua Lopes Chaves, } 108 \\
\text { S. Paulo }
\end{gathered}
$$

Mário, aconselhado por Bandeira, reconhece em Lobato uma mão importante, aceita seu convite e envia os livros. Anos mais tarde, deliberadamente ou não, esquecerá o fato e dirá que não pôde aceitar a requisição pois já se havia comprometido com outra pessoa (o caso será abaixo relatado). Em carta a Manuel Bandeira em dezembro de 1930, sem embargo, Mário demonstrava não acreditar na boa-fé do colega: "quanto ao Monteiro Lobato, quase já tirei a limpo que o caso dele foi só me prender e mais uma vez provar que é um f.-d-p. muito grande"; Mário teria sido informado que "um sujeito brasileiro que mora em Nova York já andou querendo atrapalhar a tradução" (2001: 474) e não tinha dúvidas sobre ser Lobato o tal agente insidioso.

A comunicação oficial entre ambos é, entretanto, cordata, educada, sem altercações. Mesmo assim, pode-se observar aqui e ali um "ruído" remanescente de seus desentendimentos pretéritos. A carta de Lobato é toda em tom irônico, vinda do alémtúmulo para onde Mário o condenou em um satírico artigo a que breve aludiremos. Mário, por sua vez, propositalmente retoma a "brincadeira", em tom desanimadamente elogioso, apenas ao fim da resposta, sendo antes de um algo exasperante profissionalismo, falando estritamente do que lhe foi inquerido e ressaltando sua profissão de fé como artista.

Há algo mais que cordialidade entre ambos os correspondentes? Talvez Monteiro Lobato quisesse, "morto", exibir uma sua superioridade ante o mais que vivo Mário de Andrade, propondo ajudá-lo quase caritativamente? Mário, ao ressaltar sua ética de ação, estaria criticando o espirito comercial de Lobato, que ganhara muito dinheiro com vários livros que lançara? Qualquer resposta mais apressada neste momento parece conjectural.

Algo pode ser indicado com relativa precisão, todavia: a oposição diametral entre os projetos de identidade nacional, pátria e conceitos equiparados dos dois autores. Se Mário, em uma carta a Tarsila do Amaral, condena uma internacionalização a seu ver despropositada dos modernistas, deslumbrados com europeísmos e esquecidos da "entidade" nacional - "Mas é verdade que considero vocês todos uns caipiras em Paris.

\footnotetext{
${ }^{79}$ MLb 3.2.00364 CX 7 (CEDAE/IEL)
} 
Vocês se parisianizaram na epiderme. Isso é horrível!" (2001: 78-9) -, o Lobato do final dos anos 1920 é um homem confessadamente cooptado pelo sistema estadunidense ${ }^{80}$. Edgard Cavalheiro afirma: "Lobato chega a New York a 7 de junho de 1927. Quinze dias depois escreve estar americanizado, possuindo automóvel, rádio, e um belo apartamento. (...) Está realmente feliz, eufórico" (1955: 362). Lobato, em seus livros e discursos, se interessa em mostrar como o Brasil está na contramão do avanço estadunidense, para ele terra da organização e progresso. Mister Slang, o porta-voz político ficcional de Lobato no período, faz a apologia da mecanização, da tecnologia e do fordismo. Mário não poderia estar mais longe em espírito.

No mesmo 1926 em que primeiro vêm à luz os colóquios entre Mister Slang e um seu interlocutor brasileiro, que no ano seguinte seriam reunidos por Lobato em um volume único, Mister Slang e o Brasil, Mário de Andrade "mata" Lobato em um já mencionado artigo zombeteiro. Talvez ressentido ainda pela recusa de Pauliceia desvairada - as publicações dos livros do poeta, restritas, quase sempre foram bancadas por seu próprio bolso -, Mário o tacha de acadêmico, argumentando sarcasticamente que após Urupês o senhor "Bernardo Guimarães de Monteiro Lobato" nada mais tinha a apresentar, falecendo artisticamente em 1926.

Vejamos um trecho:

\begin{abstract}
“(...) O telégrafo implacável nos traz a notícia do falecimento de Monteiro Lobato, o conhecido autor de Urupês. Uma das fatalidades de que sofre a literatura nacional é essa das Parcas impacientes abandonarem no começo o tecido de certas vidas brasileiras que se anunciavam belas e úteis. Muitos literatos têm desta maneira partido pro esquecimento em plena juventude mal deram com a obra primeiro vislumbre gentil de seu talento e possibilidades futuras" (2003: 31).
\end{abstract}

Anos depois, os caminhos de ambos os paulistas voltam a se cruzar via cartas, mas com uma diferença na interlocução: agora é Lobato falando sobre Mário. A ocasião foi mais uma vez o ressentimento literário, desta vez nutrido pelo jovem escritor de São Paulo Flávio de Campos. Não é objeto deste trabalho deter-se em considerações sobre sua obra, portanto sintetizaremos brevemente o episódio: Mário, crítico do jornal Diário de

\footnotetext{
${ }^{80}$ Lobato, porém, compartilha com o Mário desse momento o sentimento de enfado pela cultura francesa, que ainda era um poderoso ímã para a intelectualidade brasileira. Carlos Drummond de Andrade, em carta a Mário em 1924, confessava-se "acidentalmente brasileiro (...). Detesto o Brasil como a um ambiente hostil à expansão do meu espírito. Sou hereditariamente europeu, ou antes: francês. Amo a França como um ambiente propício, etc" (2003: 59). Lobato, em um artigo sobre Kipling, depõe que, considerando a classe dita alta, "o fascínio da França foi tão forte nessas almas simples que não conseguiram ir além. Pararam em Paris e, a fim de justificar a parada, encamparam a sério, botocudamente, a altíssima ideia que o francês faz de si próprio" (2010b: 277).
} 
Notícias, comentando estreias literárias, ocupa-se brevemente do romance de Campos, Planalto. Os comentários de Mário aparentemente não agradaram ao escritor estreante, que sentiu seu trabalho ser pouco valorizado. Marisa Lajolo teoriza que a "crítica tão labiríntica parece ter desagradado ao jovem escritor que, provavelmente, queixou-se de Mário a Lobato, certamente à espera de simpatia e solidariedade" (2008: 156).

Lobato, contudo, não toma seu partido. Sua resposta ao jovem colega defende o direito de a crítica se expressar livremente e faz a apologia dos talentos analíticos e da honestidade intelectual de Mário:

Tu és um monstro de orgulho, Flávio. Pois queres atacar ao Mario só porque ele exerceu o seu natural direito de crítica? (...) Mario é notabilíssimo. Mario, pelo seu talento sem par no analismo criticista, tem direito a tudo, até de meter o pau em você e em mim. Eu tenho levado pancadinhas dele. Certa feita (...) matou-me e enterrou-me. Em vez de revidar, conformei-me, e sem mudar minha opinião sobre ele. (...) Mario é grande. Tem direito até de nos matar à moda dele" (1997: 181/4).

No mesmo Diário de Notícias em que criticou o romance de Flávio de Campos poucos meses antes, no dia 26 de maio de 1940 Mário comenta o caso Lobato. Vale ler o trecho na íntegra:

"Do sr. Monteiro Lobato ficamos sabendo que se considera o criador da indústria editorial no Brasil, e sempre é certo que o artista dos Urupês foi o editor cauteloso e hábil, a que deve bastante a literatura brasileira. Eu mesmo lhe devo um favor que precisa ser proclamado. $\mathrm{O}$ sr. Monteiro Lobato, a pedido de um amigo comum daqueles tempos, prontificou-se a editar Paulicéia desvairada depois do merecido escândalo que causou a publicação de apenas um dos hórridos poemas desse livro. Mas o sr. Lobato hesitava muito. Não queria, naturalmente, prestar um desserviço às nossas letras, nem a mim, vago professorzinho de piano, que fazia versos malucos nas minhas horas de iluminação. E com isso os originais modorraram meses e meses a fio nas gavetas do grande editor. De vez em quando, ele retirava o manuscrito do esconderijo, percorria-lhe as páginas e sacudia a cabeça pensativo. Enfim, mandou me chamar, me acolheu muito bem, e disse franco o seu pensamento sobre o livro, ou melhor, o seu não-pensamento, pois confessou não compreender neres daquilo tudo. E me disse: 'Você não poderia escrever um prefácio, uma explicação dos seus versos e da sua poética?' A ideia era esplêndida, e foi a pedido do sr. Lobato que escrevi o 'Prefácio interessantíssimo', a melhor parte do livro, na opinião dos que perdem tempo e verdade, gostando um bocado de mim. É certo que os originais acrescentados, continuaram dormindo sobre a justa inquietação do editor, até que depois de mais de ano de amadurecimento, ele os devolveu intactos. Ainda não rompi com o sr. Monteiro Lobato. Rompi depois, quando ele fez a mesma coisa, e já agora injustificadamente, com um livro de poesias do sr. Manuel Bandeira. Na primeira ocasião, matei por escrito o sr. Monteiro Lobato. Mas o sr. Lobato, que é a bondade em pessoa, não brigou comigo não. Quando estava morando em Nova York, um dia me mandou uma carta de pazes, na qual, imaginando a possibilidade de serem vertidos para o inglês certos livros meus, me propunha enviasse uma procuração que lhe permitisse cuidar dos meus interesses lá na terra grande. Infelizmente, não pude aceitar a generosidade, porque, por estranha coincidência, por esse mesmo tempo, a sra. Margaret Hollingsworth, 
que conhecera os meus livros, e vivia também em Nova York, já estava se dando ao trabalho de me traduzir. E seria uma indelicadeza da minha parte não tratar dos meus negócios diretamente com ela. Nada me impede que eu guarde do sr. Monteiro Lobato uma ternura imensa. Soube ser superior aos meus despeitos e me deu o "Prefácio interessantíssimo"” (1993: 197-8).

Da análise do excerto vemos muito do explanado. Destacamos: a ironia consciente de Mário para com Lobato ("o grande editor"), o sarcasmo que o faz pintar Lobato atônito retirando o original de Pauliceia de sua gaveta repetidas vezes para análise - e a correlacionada ignorância poética do editor -, a tentativa de "paz" de Lobato durante sua estada em Nova Iorque, a não efetivação da parceria entre os dois autores.

Mas uma informação resta incorreta, como também já indicado. Mário manda sim o que seu colega pede. Engano inocente ou tentativa forçada de estabelecer uma maior "integridade" em um caso que sempre o ressabiou? Escrevendo sozinho ao jornal, sem interlocução articulada explicitamente, Mário pode narrar sua versão e sair ileso de suas contradições. Não se conhece reação de seu alvo. Lobato, "a bondade em pessoa", não havia de reclamar: "Mário tem direito a tudo, até de meter o pau em mim". 


\section{ANEXO 3. CARTAS E CORRESPONDÊNCIAS COLETADAS NOS ACERVOS DO IEB, UNICAMP E BIBLIOTECA MONTEIRO LOBATO}

Pesquisando os arquivos de correspondências de Monteiro Lobato constantes no Instituto de Estudos Brasileiros (IEB) da USP, na Biblioteca Monteiro Lobato e no Centro de Documentação Alexandre Eulalio (Unicamp), encontramos uma série de documentos convenientes ao seu tema de trabalho. As cartas transcritas apresentam eixos comuns: o alcance da obra lobatiana em relação a seus leitores e os temas políticos, ou relacionados aos Estados Unidos, à economia brasileira e às campanhas de Lobato por ferro e por petróleo, bem como traduções para outros idiomas. Citadas alusivamente em alguns pontos da dissertação, a coleção completa, com pertinentes e cuidadosas notas de transcrição, mostra-se significante e valioso complemento às informações contidas no texto geral e são de interesse notável ao pesquisador e leitor lobatiano, daí sua anexação.

Notas:

1. Ao lado do nome do correspondente, colocou-se a localização do documento no acervo pesquisado;

2. Mantidas as grafias originais, com a ortografia da época e eventuais erros ou equívocos dos correspondentes, os mais evidentes marcados com (sic);

3. Efetuados ocasionalmente pequenos reparos na pontuação original;

4. Imprecisões ou dúvidas foram completadas ou anotadas entre colchetes;

5. Optou-se por retirar as anotações "filológicas", tais como rasuras, acréscimos e correções, marcações a lápis ou caneta e afins, preservando-se apenas certas observações identificatórias (etiquetas, cartões);

6. As cartas são identificadas pelas seguintes cores e temas:

Azul: Recepção da obra de Monteiro Lobato junto a crianças e jovens;

Vermelho: Recepção da obra de Monteiro Lobato junto a adultos;

Roxo: Lobato e correspondentes estrangeiros;

Verde: Cartas, mensagens e textos escritos por Lobato;

Laranja: Contemporâneos de Lobato escrevem sobre e para ele. 
Carangola, 21 de abril de 1936

$\mathrm{Ex}^{\mathrm{mo}} \cdot \mathrm{Sn}^{\mathrm{r}}$. D ${ }^{\mathrm{r}}$. Monteiro Lobato

Saudações

Participo-lhe que, aos 23 do mes de março foi fundada na classe do $2^{\circ}$. anno $\mathrm{MF}^{1}$, do Grupo Escolar "Interventor Valladares" desta cidade, uma "hora de historia" a qual recebeu o nome de "Monteiro Lobato", nome este escolhido por nós em classe, porque gostamos muito das suas histórias.

Aproveito ainda a opportunidade para participar-lhe a organização da nossa biblioteca, cujos livros leremos á hora de historia e se o Snr. quizer nos dar o prazer de enviar-nos alguns dos seus livros, ficaremos muito contentes.

Elles poderão vir para o nosso Grupo, com o seguinte endereço: $2^{\circ}$. MF1- Grupo Escolar "Interventor Valladares" - Carangola - Representando o $2^{\circ}$, anno $\mathrm{MF}^{1}$, ao qual pertenço, subscrevo-me.

\section{Adelino Meurrier}

ISIDE M. BONINI - 11/12/1935 (RAS - DML - CP/CA, CX 04, P1 - 002)

Rio - 11/12/35

Querido Snr. Monteiro Lobato.

Permita-me chama-lo assim, pois que tudo o que tem feito de bom e de bonito, obriga a gente chama-lo assim.

O fim desta é pedir-lhe a grande gentileza de uma "ou mais" collaborações para uma revista infantil "Mundo Pequeno" que estou organizando e pretendo lançar entre Natal e Anno novo.

Sei que, amigo declarado das creanças, não deixará de attender a esse pedido, embora feito por uma "creança já muito grande" e que gentilmente acederá, porque Mundo Pequeno não pode deixar de possuir, para seu grande orgulho, qualquer coisa feita especialmente pelo querido Monteiro Lobato.

Aguardo anciosa o resultado do meu grande atrevimento, e apresento-lhe os mais sinceros protestos de sympatia.

Cordialmente

Iside M. Bonini

Redacção - R. Rodrigo Silva - 2o.- s. 4 e 5 
Rio

LUCIA VIZEU LAPORT - 03/02/1936 (RAS - DML - CP/CA, CX 4, P1 - 003)

Alto da Boa Vista 1512.

Rio de Janeiro.

Monteiro Lobato.

Cordeais saudações. Quero, antes de mais nada, agradecer em nome de meus filhos a distracão incomparavel que seus livros lhes proporcionam.

Realmente, o senhor é o querido de toda a petisada, e hoje em dia Monteiro Lobato é para eles como costumava ser, no meu tempo de crianca, os contos de "Mil e uma noites".

Desejava, pois, pedir-lhe um grande favor. Poderia o senhor, assínar o livro que vai junto para eu guardar, como reliquia, para os meus filhos: "Lucia Maria e Francisco?

Creio que o senhor não me negará tao grande obsequio, e ser-lhe-ei imensamente grata.

Si lhe causar algum prejuiso, enviar-me de volta, o volume, seria grandemente reconhecida si me permitisse indemnisar seu prejuiso.

Antecipadamente lhe agradeço de todo o coração em nome de Lucia Maria e Francisco.

Lucia Vizeu Laport.

3 de Fevereiro, 936.

GUSTAVO SILVA - 04/05/1936 (R15 - DML - CP/CA, CX 4, P1 - 004)

S. Paulo, 4 de maio de 1936.

Snr. Monteiro Lobato.

A carta que o senhor ha tempos me escreveu, encheu-me de alegria. Porem houve uma pequena "virada" em minha vida; ella melhorou um pouquinho. Graças á bondade dum amigo querido, tenho tido dinheiro para cigarros e cinema.

Essa melhoria em minha situação prejudicou-me um pouco. Acostumado há muito tempo a viver com a mão em bolsos vazios, senti-me rico quando pude contemplar algumas notas de $5 \$$ ou $10 \$ 000$. 
Ha na minha familia pessoas que dizem têl-o conhecido quando mais moço. Meu tio Carlos Fonseca, funcionario quasi aposentado dos Correios e Telegraphos, contou-me que foi seu companheiro "de republica". Minha tia Sinházinha, uma senhora bôa, delicada, que eu, francamento, estimo demais, conheceu-o em Taubaté quando era mocinha. Ella falou em passeios e na Viscondessa de Tremembé, que, segundo ella diz, era sua avó.

Minha mãe conheceu sua irmã ou irmãs - não me lembro bem.

Eu, porem, não o conheço, a não ser pelas suas obras, photographias, etc...

É esse desejo de conhecêl-o que me impelle a escrever-lhe. O senhor foi tão delicado e bondoso em escrever-me aquella carta...

Mostrar-lhe-ia de boa vontade, com muito prazer, alguns dos meus desenhos desageitados. Prefiro, porem, fazêl-o pessoalmente. Por que o senhor não me telephona pedindo para ir visitál-o, ou antes, incomodál-o, já que não sei fazer coisa melhor?

Aguardo uma resposta para a rua Anhangabahú no $11 \mathrm{ou}$, em telephone, para a Cruz Azul, avenida Tiradentes (como mamãe não está em casa, não sei o número do aparelho). Porem basta consultar a lista. Das 8 ás 12 horas mamãe, D. Lindinha, está lá. É só chamál-a e pedir para transmittir o recado.

Para não ioncomodál-o mais, despeço-me, rogando-lhe não se esquecer de mim.

Do seu admirador

Gustavo Silva.

\section{CLYMENE CRUZ - 22/10/1937 (RAS - DML - CP/CA, CX 4, P1 - 005)}

Sr. Monteiro Lobato.

O Grupo Escolar "José do Patrocinio", a rua 04 de Outubro, 9, em Campos, recebeu como os outros desta cidade, 40 volumes para com eles ser fundada a sua biblioteca.

Sendo eu, professora deste estabelecimento, dei, em nome do meu filhinho, uma pequena estante a qual batisei com o seu nome - Monteiro Lobato - e nela quero somente que haja livros de sua autoria.

Já consegui os seguintes volumes: Contos de Grimm; Arimetica da Emilia; O Sacy; Viagem ao céu; Novas Reinações de Narizinho; Contos de Andersen; Novos contos de Andersen; Mowgli, o menino lobo; Aventuras de Hans Staden; Emilia no paiz da Gramatica; Historia do mundo para as crianças. Mas vejo com tristeza que muitos me 
faltam. Não pouparei esforços para proporcionar aos meus queridos alunos a leitura sã e agradabilissima dos seus livros.

Campos, como talvés, já tem ouvido falar é uma verdadeira colmeia de trabalho onde muito se estuda. Ficariamos imensamente orgulhosos e gratos se algum dia, como muitos outros intelectuais, viesse conhecer a Perola do Paraiba.

Subscrevo-me atenciosamente,

Clymene Cruz.

Campos, 22-10-937.

A. COELHO - 10/02/1938 (RAS - DML - CP/CA, CX 4, P1 - 006)

603 West 138,

New York City

Feb. 10, 1938.

Dear Pwizinho [Paizinho?]:

For a long time I have been wanting to write you a letter, but wanted it to be a chronicle of things happening in the house of Coelho - but I did not realize that I would have to write under such sad circumstances!

Our hearts are all with you in the loss of your boy! It seems a sad bitter pie to have to swallow - and I know how crushed you must be.

Sometimes I feel that it is the joy we derive from our children up to the twice they are 20 - that really amounts to something. It seems to me the time when we mean bust [?] in their lives when we are the closest.

Do write me something when time has amuaged [?] some of the bitterness of your grief. I would [?] love to hear from you again.

I never pass the apartment of Broadway that I don't think of you dear people. It would [?] be so nice if you would [?] come back again - when I shall ever get to Brazil is a guesteers [?] - but who knows - some day I may knock at your front door yet.

Mother and father are better now - mother was very ill this fall - [incompreensível] she is back playing the organ in church - Father is quite remarkable in his come-backs. He has had such [incompreensível] and now doesn't look a day over 70. I am [incompreensível] a couple of [incompreensível] shots of [incompreensível].

It is fortunate, my dear, that you have other children - I often wonder what I would do if I lost [incompreensível]. My deepest love to you all. 
A. Coelho.

FRAGMENTO DE CARTA, Rio, 9/7/40 (RAS - DML - CP/CA, CX 4, P1 - 007)

Rio 9 - 7 - 40

Lobato:

Essa reforma da natureza está saindo do arco da velha. Ainda agora tive uma "idéia tataravó" de tão formidanda, se bem que um pouco desproporcional; veja lá: dizem todos por aí, que "a vida começa aos quarenta". Ora, a Emília, achando ruim isso da gente vegetar 4 decênios, lustres [?] sem viver, pode resolver o inconcebivel: as pessoas nascem com 40 anos! Assim se mata a tal charada. A gente nasce e zás tráz! vive! Que tal? Eu acho a coisa mais econômica do mundo...

Outra coisa mal feita: eu estou aqui sentada e se quero apanhar o dicionário tenho que me levantar, gastar meio quilo de energia até a estante para pegá-lo. Não seria melhor que a nossa carne fôsse elástica? Bastava estender o braço e nhoc! O livro estava seguro! Como seria cômodo...

Tenho estudado bastante. Ainda outro dia, na aula de português, a aula mais gozada do planeta, eu escrevi na pedra uma composição sobre as colheitas de Portugal com o estilo mais português do mundo. Até o "milho rei" apareceu...!

Os cágados o aborrecem? Nada mais fácil; esborrache com a porta o nariz de cada um, e arranje um alto-falante emiliano que contínuamente os mande bugiar no mato. E se êles ainda teimarem, pulverize "Flit" em cima dêles... não tenha dó!...

Estou me aborrecendo muito com êsse Rio de Janeiro duma figa. Só há arranhacéu! Enjôa! A Emília bem que podia virar essa droga dessa cidade de pernas para o ar. Isso por cá anda cada vez pior...!

Camon, a Lambeta bem que podia arranjar no sítio uma cultura de sereias... nunca me conformei com a perda daquela uma, que era o encanto em pessoa. Ah, se na minha visita ela estivesse lá... eu seria até capaz de trazê-la para criar num copo dágua.

Agora me lembrei duma boa reforma. A luz elétrica é muito bela mas... não é bem, bem, bem ótima. E se eu e a danada da Emília subíssemos até o céu (de que maneira? Ora, que pergunta ingênua... subíamos pelas minhas tranças...) e com[o] duas Prometeus malucas arrancássemos uma pulguinha luminosa do senhor sol e a trouxéssemos para o sítio? Nunca mais haveria sombra! Seria a maravilha das maravilhas. Podemos também inventar uma árvore que dê sorvetes em vez de frutas.

Ah, Camon, há tantas, tantas coisas que não podem sair. Embatucaram. É preciso puxá-las com canivete. 
Agora fui refrescar an cabeça na porta e tive outras idéias. Primeiro: é muito aborrecido isso dos cigarros se acabarem logo, não é? Pois inventemos cigarros elétricos que durem a eternidade. E em vez da cinza luminosa, haveria uma lâmpada de 1 [?] vela. Outra boa: as pessoas piolhentas muito se amolam com o negócio dos piolhos estarem agarrados ao crânio. Pois façamos com que êles se alojem na pontinha do cabelo, de maneira que para se livrar da piolhada, basta cortar o cabelo... Coisa mais humanitáriamente útil, não há! E depois haveria menos gente com praga na cabeça, e mais pessoas de côco luzidío, completa(...)

TEREZINHA DANTAS - 15/01/1942 (RAS - DML - CP/CA, CX 4, P1 - 008)

Rio, 15 de Janeiro de 1942.

Monteiro Lobato

Antes de mais nada, apresentando-me: Terezinha Dantas, uma das suas admiradoras.

Talvez o sr. não se lembre mais de mim, mas o certo é que eu já lhe visitei aí em S. Paulo.

Sou sobrinha do Silveira Peixoto. Quando estive aí, em princípios de 1940, ví satisfeito o meu maior desejo: conhecê-lo pessoalmente.

Sendo o sr. o melhor escritor que conheço, reparará por certo, os erros que já cometí nessa carta, mas peço-lhe para perdoá-los.

O objetivo desta carta é duplo:

Em primeiro lugar quero que o sr. faça uma dedicatória no retrato que lhe envio. Encontrei-o num jornal e espero que o sr. satisfaça o meu pedido.

O segundo objetivo é o seguinte: gostaria que o sr. publicasse um livro com a turma do "Pica-páu Amarelo".

Queria uma aventura bem emocionante onde a Emília estivesse bem "asneirenta" e o "Rabicó" bem “comilão"...

O sr. me prometeu que botaria o nome do "Manchinha, um gato meu, no seu livro e espero que não se esqueça disso.

Vou despedir-me, esperando anciosamente que me escreva respondendo às minhas perguntas.

Saudades de

Terezinha

Meu endereço: 
Terezinha Dantas

Laranjeiras n. ${ }^{\circ} 354$ q. 12.

Rio

TEREZINHA DANTAS - s/d (RAS - DML - CP/CA, CX 4, P1 - 009)

Sr. Monteiro Lobato.

Lí seu livro e gostei muito dele.

Vi também que o senhor não se esqueceu do meu querido gatinho. Achei-o "meio" malvadinho, mas, gostei bastante.

Achei muito interessante a alusão que o senhor fez ao americano do norte que logo se adapta às circunstâncias progredindo o mais possivel. A Emílinha sempre a mesma: açambarcando o papel principal com uma graça da qual só ela mesma é capaz. Todo o assunto do livro me prendeu e tanto foi assim que o lí em uma manhã.

Andei relendo alguns dos seus livros e ainda gostei mais deles. É sempre assim - quanto mais se lê qualquer obra mais coisas interessantes lá se acha. "Reinações de Narizinho" eu lí em cinco ou seis vezes! Um que gostei muito tambem foi "As caçadas de Pedrinho". E, de todos, o melhor a meu ver, foi "Memórias da Emília". O senhor bem que podia fazer com que o anjinho não fugisse! Foi uma pena! Tão bonitinho que ele era! Uma "galantezinha"...

Voltando ao seu último livro - imagine o meu medo si fosse eu quem se escondesse no buraco das baratas em vez do Coronel Teodorico! Eu tenho pavor de baratas. E a bicha me cutucando com uns "bambús"... Credo! Como diz a Nastacia...

Fiquei com pena foi do Manchinha. Ele era tão bonzinho e o senhor o fez comer os pais do Juquinha e da Candoca! Fiquei até zangada com o senhor! E o Rabicó! Que malvado! Mas isso sempre foi assim e não era de admirar.

Gostei muito do "sítio da Emília". Um amorzinho! Com janelinha, porta, escadinha e até arvores-cogumelos! O visconde coitado é que teve de carregar todos aqueles badulaques na cabeça!

E "Pail City"! Formidavel! Imaginei-me até comendo minhocas...

Bom, a carta já está bem grande e aquí vou parar.

Espero que o senhor goste do desenho que mandei. Representa a turminha com o senhor fazendo uma visita a eles. A Emília está dizendo uma "asneirinha", como sempre e tia Nastácia vem lhe oferecer seus célebres bolinhos. Fiquei até com agua na boca ao escrever 
isso.... O Manchinha também entra no quadro. Faz de conta que depois que todo mundo ficou normal ele foi morar no "Picapau Amarelo'.

O senhor me promete que, no seu próximo livro, ele fará parte da "turma do Picapau"?

Vou me despedir aquí aguardando sua resposta a essa minha pergunta. Antecipadamente já sei qual é e por isso já estou ficando toda contente. Escreva-me logo, sim? Vou contar os dias.

Bom, até logo e muito obrigada por tudo.

Therezinha Dantas

Meu endereço é:

Rua das Larangeiras 354 -

quarto 12

Rio de Janeiro

$\mathrm{x}$

\section{H. E. SCHROEDER - 09/06/1942 (RAS - DML - CP/CA, CX 4, P1 - 010)}

Diamantina - Minas Gerais, Macau de Baixo. 9 de Junho de 1942.

Ilmo Senhor,

Com muito prazer aprendi conhecer seu excelente livro emtitulado O Minotauro.

Agradou me muito e excitou meu interesse de modo que o li todo com atenção e satisfação.

Este meu interesse me fez notar algo, um engana não do seu lado mas sim do que embelezou sua obra de figuras.

Pois na pagina 188 fala-se, como deve ser, do tripede da Pitia, mas a representação na pag, 189 mostra uma cadeira de quatro pés.

Com muita estima e particular consideracao

tenho a honra de ser

de V.S.

admirador e venerador

Dr. H. E. Schroeder 
IIlmo Senhor Monteiro Lobato

aos cuidados da Firma "Companhia Editora Nacional" rua dos Gusmoes 118 - S. Paulo.

DJALMA FONSECA - 12/07/1942 (RAS - DML - CP/CA, CX 4, P1 - 011)

Juiz de Fora, 12-7-942

Sr. Monteiro Lobato:

Foi inaugurada, na classe de $3^{\circ}$ ano primário, a Biblioteca "Monteiro Lobato" escolha esta feita pelas crianças que são "fans" de seus lindos livros e encantadoras traduções. Já temos alguns volumes e 30 alunos sócios da Biblioteca.

Desejavamos para a nossa galeria, um retrato seu. Já temos o quadro. Aguardamos com grande anciedade e agradecemos este favor.

Dagmar Fonseca (professora da classe)

Rua Tavares Bastos, 126

Juiz de Fora

Grupo escolar "Umberto I", Avenida Rio Branco, n 2.585

DOROTHY BYRINS - 16/08/1942 (RAS - DML - CP/CA, CX 4, P1 - 012)

175-06 Devonshire Road

Jamaica, New York

Aug. 16, 1942

Dear Mr. Lobato,

Two months ago I started to study Portuguese. A week ago I had the good fortune of obtaining a copy of your Portuguese edition of "Alice in Wonderland". I was delighted with it - so much so, that I felt impelled to write and tell you so.

You have completely caught the spirit of "Alice" - something not easy to do. It takes a very special gift to be able to translate a work so essentially English in character. Please accept my heartiest congratulations. 
I should like to be able to read your other translations - but alas! I cannot seem to find them in New York. I wonder if you would be good enough to tell me where I might secure your other books? I should be greatly indebted to you for any information you might give me.

Perhaps you are wondering why I am interested in "Literatura Infantil"! I find such reading admirable in keeping me attain a rapid reading mastery of Portuguese.

Again my deepest appreciation of your delightful "Alice".

Sincerely yours,

Dorothy Byrns

(over) (Mrs. Arthur S. Byrns)

P.S.: I am enclosing six international reply coupons which you can exchange at your post office for a five mil reis stamp, which represents the cost of an air-mail reply to the United States.

DB.

Language Service Center

18 W. 41 St.

N.Y

JOSÉ HEITOR ROCHA - 23/07/1943 (RAS - DML - CP/CA, CX 4, P1 - 016)

Aracajú, 23 de julho de 1943

Ilmo. Sr. Monteiro Lobato

Saúde

Tendo lido já toda a coleção de livros, escritos por V. S. para a juventude Nacional, julgo que é um dever agradecer a V. S. o muito que tem feito pela mocidade estudiosa do Brasil, da qual faço parte. Li, com prazer, todos os varios livros da coleção para crianças como tambem algumas traduções e adaptações achando-as simplesmente formidáveis, não só pelo formato como pelo metodo que emprega, que instrui e diverte ao mesmo tempo. Ficaria muito honrado se o grande escritor patrício, se dignasse responder-me esta, sendo para mim um documento valiosissimo dadas, ja a vossa capacidade literária verdadeiramente astronomica, ja o vosso nome amplamente conhecido em todo o Universo. Uma resposta a esta carta faria os meus colegas "babarem de inveja" como diria nesse caso a gosadíssima Emilia. Esperando brevemente a vossa honrada resposta, sou o vosso amigo e admirador: 
José Hilton Rocha

Educandário "Jackson de Figueiredo"

Praça Olimpio Campos, 326

Aracaju - Sergipe

ARI REGINALDO SOARES - 13/01/1944 (RAS - DML - CP/CA, CX 4 - P2, 02)

Galia $\quad 13-1-44$

Saudações

(...) Talvez esteja enganado ou mal informado, quero apenas frisar o quanto o senhor deve ficar satisfeito com a goria. É verdade que o senhor gastou muita energia para convencer os brasileiros das necessidades dos Jécas, da precisão do petróleo. Dirá o senhor que seria injustiça esquecer-se do homem que fez a imprensa brasileira, mas quem diz-lhe que o homem é justiceiro?

(...)

Do seu admirador,

Ari Reginaldo Soares.

ARI REGINALDO SOARES - 12/02/1944 (RAS - DML - CP/CA, CX 4 - P2, 03)

“Galia 12-2-1944

Saudações

Querido mestre, aqui estou novamente. Só agora depois de ter lido grande parte do "Urupês" é que compreendi que não homenagearam o Monteiro Lobato do petroleo, o Monteiro Lobato dos caipiras, mas sim o Monteiro Lobato dos livros, o escritor. Não me arrependo porem de ter-vos dito que o homem não é justiceiro, embora saiba que é uma temeridade dizer isso a um advogado.

$(\ldots)$

Acho dever acabar,

Do admirador,

Ari Reginaldo Soares. 
ARI REGINALDO SOARES - 02/12/1944 (RAS - DML - CP/CA, CX 4, P2 - 05)

São Paulo no dia 2 de Dezembro de 944

Saudações

$(\ldots)$

$\mathrm{D}^{\mathrm{r}}$ hoje sei bem o que vale o seu título, quer dizer 10 anos de estudos e promotor sei que não diz pelo motor. Parece que compreendi o motivo pelo qual o senhor não quiz advogar mais. Em que ficou o negocio de Petroleo? Que faz o doutor a não ser traduzir e porque tem o nome de Lobato o lugar num dos estados do norte onde ha petroleo? E si lhe homenageiam nas bodas de prata literaria porque não lhe dão um lugar na Academia?

$(\ldots)$

Responda-me, sim? Gosto do senhor,

Ari Reginaldo Soares.

ARI REGINALDO SOARES - 17/03/1945 (RAS - DML - CP/CA, CX 4, P2 - 07)

São Paulo 17 Março 945

$(\ldots)$

Falando em política que acha do novo golpe do Getulinho? eu o acho esperto, muito esperto, e a situação do Assis Chateaubriand agora? Digo porque o Diario da Noite apoiava o Eduardo Gomes, não falarei mais para não errar, o senhor sabe o que passa melhor que eu que pouco leio os jornais.

Recomendações a sua senhora, do sempre disposto a servi-lo,

Ari Reginaldo Soares

ARY MOREIRA - 15 DE NOVEMBRO DE 1944 (RAS - DML - CP/CA, CX 4, P2 029)

Niterói, 15 de Novembro de 1944

Prezado Snr:

(...) Estava eu no curso Ginasial, quando assistindo a uma aula de Geografia, o professor chamou-nos a atenção para um problema que já se tornou crônico, para nós brasileiros: o Petróleo. Com o espírito assim despertado, procurei obras que melhor me esclarecessem o assuntom e foi assim, que lí e relí: "O Drama do Petróleo no Brasil" por Emílio de Maya e a "Luta pelo Petróleo" de Essad Bey, em tradução feita por V. Sa. 
Neste último livro, as suas notas, tornaram-me inoculado pelo assunto, induzindome a ler "O Escândalo do Petróleo", obra que me trouxe ao conhecimento, de um modo irrefutável, a lazeira existente nesse setor da vida nacional.

$(\ldots)$

Atenciosamente,

Ary Moreira

Nome: Ary Moreira

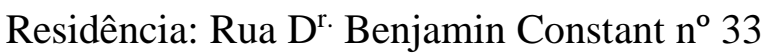

Niterói - Estado do Rio

\section{ALICE D. VON TREXLER - 02/1945 (RAS - DML - CP/CA, CX 4, P2 - 036)}

Jaboticabal, fevereiro de 1945.

Estimado "Seu” Lobato!

(...)

O último livro que li, de sua autoria, foi "O escândalo do petróleo".

Meu colega de escola, o primeiro da classe e talvêz do colégio todo, é um filho de japonês: Matinas. É, como eu, um fervoroso admirador seu; sempre mexemos na biblioteca desfalcada, lendo tudo. Um dia, encontramos seu livro, atráz de uns volumes de geografia, meio abandonado. Quíz lê-lo, mas meu colega tomou o livro de mim. Queria ler primeiro, depois eu leria.

Ele leu e não falou nada durante algum tempo, mas quando começou, não parou mais. Estava revoltado com tanta hipocrisia, falsidade e imundície no governo. Esconder o petróleo! Fiquei mêses implorando para ler o livro e ele não m'o deu com a desculpa: "Eu conheço você, Alice, e sei que vai ficar fora de si, qdo. ler. Eu conto alguma coisa". Mas... água mole em pedra dura... Li o livro. Não sei nem explicar a sensação que eu tive. Fiquei bufando longo tempo e admiro a tenacidade sua, em tratar da busca do petróleo. Seu livro é admirável e pode crer, o objetivo que tinha ao escrevê-lo, foi plenamente alcançado em mim e em Matinas. Falamos longamente, com grande tristeza sobre o assunto. Nós o compreendemos perfeitamente, e com que gosto o ajudaríamos, se pudéssemos. Meu amigo, este ano, ingressa na faculdade de medicina, e eu que acabei o científico com ele, ganho a vida dando aulas particulares a alunos atrazados, porque o estudo superior no Brasil está fora do alcance da maioria dos estudantes. Nós não somos nada, pelo menos ainda não somos nada para poder ajudar homens de boa vontade como o senhor. Olhe, "seu" Lobato, gente honesta, de bons propósitos, no meio de tanto cafageste rico e poderoso repimpado no governo é "fosque apagado!". Aquele seu livro, 
que encontramos na biblioteca semi-abandonada, não está mais lá... Figura na biblioteca de Matinas. Foi preciso furtá-lo, porque nas livrarias não está à venda. Pelo menos aqui não. Ninguem notou o roubo!

$(\ldots)$

\author{
Alice \\ End. Alice D. von Trexler \\ Rua Floriano Peixoto, 17 \\ ou simplesmente Jaboticabal
}

\title{
CARTA DE LOBATO A PUREZINHA - MLb 3.1.00168 CX 3 (CEDAE/IEL)
}

[Papel do Hotel Statler em Detroit, com a imagem da fachada do hotel, o slogan "1000 rooms, 1000 baths" e os dizeres "Under same management HOTELS STATLER Boston, Buffalo, Cleveland, St. Louis / HOTEL BUFFALO, Buffalo / HOTEL PENNSYLVANIA, New York]

Dear Purity

I am here and begin to visit the Ford plant. Too big! To day [sic] I have seen $1 / 1000$, and I must spend one thousand days to see all. But don't worry. I will see only $5 / 1000 \ldots$

Go to the movies and don't worry about me.

$$
\text { Juca }
$$

Fiel [? Tiel?] to Monday or 3ça.

\section{CARTA DE LOBATO A MÁRIO DE ANDRADE - MLb 3.1.00169 CX 3 (CEDAE/IEL)}

New York, 6 agosto, 930

Meu caro Mario de Andrade,

Muito ha de voce de espantar-se com esta, vinda dalem tumulo, dum morto que voce matou ha tres anos atraz. Mas ha de tudo na vida, até os mortos que escrevem cartas aos matadores.

O que me traz é um livro seu - Macunaíma. Tenho cá um editor que deseja conhececel-o, com palpite que é coisa editavel em inglez. Se voce está por isso, mandeme um exemplar e se achar que um morto pode representar um vivíssimo, mande tambem autorização para eu tratar com o homem. 
É incrível como dá voltas o mundo! Vou eu ajudar o Mario a publicar-se neste paiz e ajudar na traducção. Vou sahir da cova só para isso. Depois recolherei de novo, porque não existir é a delícia das delícias, caro Mario.

Hurry up. Manda logo dois exemplares e depressa.

Do seu matado

M. Lobato

Monteiro Lobato

3505 Broadway, New York City

\section{LOBATO AO DIARIO DE S. PAULO - MLb 3.1.00202 CX 4 (CEDAE/IEL)}

\section{S. Paulo,6,2,948}

\section{Meu caro DIARIO DE S. PAULO:}

Uma reportagem sua de ontem me acusou, ou insinuou coisas. Receba lá a minha justificação. As boas contas fazem os bons amigos.

A grande acusação foi de que ofereci um livro a um amigo. Minha resposta é que a Constituição deste país não proíbe a oferta de livros, nem condena as dedicatorias. Tenho completa liberdade de o fazer e tenho usado desse direito. Creio que em minha vida de escritor e editor já ofereci livros aos milhares, e sempre com breves dedicatorias, sem que jamais me passasse pela cabeça que isso pudesse ser censuravel e anticonstitucional.

- A questão não é oferecer um livro sobre a historia do comunismo russo.

- Meu caro jornal: a mesma Constituição que nao me veda oferecer livros, também me dá plena e absoluta liberdade de escolha. E como tenho liberdade de escolha, tanto posso oferecer um livro sobre numismatica, como sobre a historia contemporanea. E continuando a minha liberdade de escolha, entre os assuntos historicos do momento posso escolher o comunismo russo, que tanto para mim, como para Truman e Marshall é dos mais empolgantes. Note oc [sic] como eles se preocupam com o assunto. Realmente, não ha assunto de maior atualidade, e se eu pudesse oferecia uma historia do comunismo a todas as pessoas deste país, para que todas pudessem pensar sobre o assunto com perfeito conhecimento de causa, e não como manda o bispo

De modo que, meu caro jornal, o "terrivel documento" que a Policia apreendeu não passa de um livro oferecido a um amigo, com dedicatoria minha, sobre assunto da maior atualidade, para que ele o lesse enquanto não aparecia uma obra similar sobre o comunismo no Brasil, o que é ainda prematuro, pois que o comunismo brasileiro até [está?] apenas começando, e não dá nem um capitulo de historia. 
Tudo isso, meu caro jornal, coisas absolutamente legais e constitucionalissimas.

Devo ainda notar uma coisa. Do todo da reportagem de ontem se depreende que sou "comunista". Muito bem - mas que tem isso? Se tenho tal ou tal ideia, isso é coisa que só me diz respsito [sic] a mim, e a mais ninguem. Tenho as ideias que quero, e não me consta que a Constituição o proiba. O belo nas constituições democraticas é justamente isso:- assegurar aos cidadãos a mais completa liberdade de ideias. Tenho o direito de ser comunista, como você tem o direito de não ser comunista. Não cometemos com isso nenhum crime, nem você nem eu. Não infringimos nenhum principio basico da Constituição: ao contrario, apenas nos utilizamos de uma faculdade que ele nos confere. Mas serei comunista?

Infelizmente não, meu caaro jornal. Apesar das minhas imensas simpatias pelo comunismo russo, pelo qual torço, um obstaculo de conciencia me vem impedindo que transforme essa imensa simpatia em adesão.

- Que obstaculo é esse?

- O georgismo. Sou georgista, meu caro. Convenci-me de tal forma da verdade das teorias economicas de Henry George, que por mais que me esforce não consigo substitui-las pelas de Caarl Marx. Admiro a logica tremenda de Marx, e talvez Marx esteja certo, mas na minha intuição a verdadeira verdade está com Henry George. E justamente, e apenas, por causa do meu georgismo não tive a honra de alistar-me no Partido Comunista Brasileiro, nem pude aceitar o convite de Prestes para entrar na chapa dos candidatos á deputação federal, em 1946. Não entrei para o Partido nem para a Camara Federal porque seria trair minhas ideias georgistas. De que modo ser um perfeito deputado comunista, se lá no fundo do meu coração eu ponho George acima de Marx? Sou muito leal, meu caro. Minha divisa é a que prego para as crianças: aquele verso de Shakespeare - "E isto acima de tudo: sê fiel a ti mesmo!"

GREYS, L. ENTREVISTA COM MONTEIRO LOBATO. s.1, Fan Magazine. pag. 22; 38, [1945 ou1948] (CEDAE/IEL)

(...)

Quando inquirí a Lobato qual a foi a maior burrada que cometeu na vida, nunca podia imaginar que me desse uma resposta tão triste. Uma resposta que me fez lembrar as lágrimas que chorei, ao ler a carta que êle escreveu a Rangel, comunicando a morte dos filhos.

- Minha maior burrada, - disse êle, - foi apaixonar-me pelo problema do ferro no Brasil. Por causa disso, por causa do interêsse com que estava mergulhado no assunto, em New York, em 1928, deixei de ir para a Suiça com minha gente, a bem da saúde do meu filho Guilherme, que tivera pleuriz num colégio de Allentown. Com tudo pronto, nas vésperas de partir, mudei de idéia, por causa do ferro-esponja de Mr. Smith. Fiquei. E por 
que fiquei, vim a perder mais tarde meus dois filhos Guilherme e Edgard, vítimas da minha "não-ida" para a Suiça naquele tempo. E dois anos depois perdí ainda tudo quanto eu tinha no jôgo da Bolsa, em New York. Entre o que perdí estava um terço das ações da Cia. Editora Nacional. Não ter ido para a Europa naquele ano, depois de haver obtido licença do govêrno, por um ano, com todos os vencimentos em ouro), foi na minha burrada n. ${ }^{\circ}$ 1. Eu era Adido Comercial naquela ocasião.

(...)

Se Lobato fôsse eleito presidente da República, que medidas tomaría para endireitar o Brasil? Vejam a resposta (cuidado, que é fórte!):

- Nenhuma. O Brasil no [sic] quer ser endireitado. A pátria não quer ser salva. Isso de endireitar o Brasil e salvar a pátria é uma bandalheira dos militares e comunistas.

\section{CARTA DE MONTEIRO LOBATO A GENERAL MEIRA DE VASCONCELOS - MLb 3.1.00170 CX 3 (CEDAE/IEL)}

(...) To save a little margin menaced of being devoured I sold (silly ass!) my share in our wonderful house of S. Paulo.

- Dont be afraid, buy stocks now. They are at the real bottom. All tendencies are up - sirens were constantly singing to "the little lamb in the woods".

Real bottom! I had to hang up, feet in air, fighting desperately to reach firm soil or real bottom as they say. Bottom followed bottom. A string of bottoms - bottomless bottoms. And the little lamb in the woods had the fortune of all little lambs in the woods.

One must have gone through such an ordeal to know what unrest means. "Account on margin, thy name is inquietude", should say another Shakespeare. Sleepless nights, inability for any kind of work, impossibility of keeping mind away from quotations, points, rallies, bear raids, bullish tips - all this crazy stuff woven and unwoven by the people who parasitate human work.

True nightmare from which just now I am recovering. Money was evaporated like snow under the sun, but what a relief! Can think again, can read, can work - can live. And can, too, realize that my failure came just because, lured by the "new economical era"s sirens I had put aside my old bible, and passed all these months without remembering that sacred horror Mr. Ford always showed for all kind of speculating activity.

Now I must start again. Had to return to my country to start again. My mission in the United States did fail lamentably. I will come back without accomplishing my designs - without seeing and talking with Mr. Ford. I gave up that old idea because I have no more right to put it forth. I dont merit to have dreamd that of meeting. I should lie as an ambassador if I met him now and went away saying: "You have changed my life and taught me what business means." I have nothing to tell him now. 
That is my true story, dear Mr. Macdonald.and in order to enable you from never forgetting its author, I am sending you a set of wooden covers. They Were destined to $\mathrm{Mr}$ Ford as a token of my farm s jungle. Bind some books with them and everytime you open some of these books dont forget to say to yourself:

- Gift of a man who came to this country just to se Mr Ford, who studied English just to talk with him - and couldn't do either.

Nobody will ever know why he couldn't, but you.

Anybody will ever know why he couldn't, but you.

\section{CARTA DE MÁRIO DE ANDRADE - MLb 3.2.00364 CX 7 (CEDAE/IEL)}

\section{S. Paulo, 31 - VIII- 930}

Monteiro Lobato,

recebi sua carta e aqui lhe mando os dois exemplares pedidos de "Macunaíma". Está claro que uma proposta de tradução pro inglês só pode ser agradavel pra um literato do Brasil. E não sou diferente dos outros, apesar de ser uma especie de edição especial, irredutivelmente fóra de mercado. Mas devo lhe confessar que vejo muito dificilmente um "Macunaíma” em inglês, ou outra língua qualquer. Careceria tirar muita coisa, e mais transportar que traduzir. Isso mesmo já falei ao pai duma senhorita Margaret Richardson que se propôs a traduzir o livro. Talvez você a conheça pois ela aí vive (The Barbizon, 63rd Lexington Ave.New York City) pensando em traduzir obras brasileiras. Nunca mais recebi notícia nem dela nem do pai e creio que ela desistiu. Não competia a mim insistir, tanto mais que as propostas de contrato eram por tal forma angustiosas que me deixavam muito frio. Dêsse geito prefiro ficar no Brasil que é mais quentinho. Não tenho ambições de ganhar dinheiro com literatura ou literatice, mas é sempre desagradavel a gente se sentir bobizado pelos outros. Caso o editor a que você se refere se confirme em traduzir o livro, você me fará o favor de comunicar a proposta dele. Si êle quiser, que me faça tambem de bobo, não me importo, porém que trate de salvar as aparencias, tão suavisantes e satisfatorias pra quem, como eu, vive sonhando com uma civilisação que acabasse de novo com o conceito de dinheiro.

No mais, seu vingado morto-vivo, viva feliz aí no comercinho de Nova York, como e quanto quiser. Porém nada neste mundo me impede de desejar você morrendo de fome nestes brasis, vivendo de expedientes, xingando de canalha e pra baixo o Washington e o Prestes, e dando pro Brasil uns novos "Urupês". Cordialmente o

Mário de Andrade

Rua Lopes Chaves, 108

S. Paulo 
CARTA DE PEDRO DE TOLEDO A LOBATO - MLb 3.2.00357 CX 7 (CEDAE/IEL)

Prezado am.o Dr.

Monteiro Lobato

Obrigado pela offerta do "Mister Slang e o Brasil".

Vou lêl-o em blóco, depois de o haver lido parceladamente, em artigos d“o Jornal”.

Renovo-lhe as minhas felicitações pelo modo original e pratico, comque tratou do complicado problema financeiro nacional, pondo-o ao alcance do povo, o mais interessado no assumpto.

Agradeço-lhe igualmente a amavel dedicatoria e a pelotada [?], que ativa sobre o sinistro heroe de Viçosa, a quem Deus guarde em sua nova prisão de Bello Horisonte, torturado pelo peor dos carrascos - o medo!...

Do patricio adm. $\mathrm{d}^{\mathrm{o}}$ edro [? incompreensível]

Pedro de Toledo

CARTA DE IRWIN M. SHALTER - MLb 3.2.00360 CX 7 (CEDAE/IEL)

[papel de ALLENTOWN PREPARATORY SCHOOL - Irvin M. Shalter, A. M., Headmaster / Allentown, PA.]

Sept. 25th, 1928.

Dr. Monteiro Lobato,

New York City, N.Y.

Dear Dr. Lobato: - I received your letter this morning and I shall follow your instructions with regard to the boys' allowance.

Your sons Edgar and William are now completely established here. They seem to like it. I just had a talk with them last evening and they assured me that everything was alright.

The one boy is taking the commercial course and the other boy is taking a regular course and is in our second year class.

The boys are fine young fellows and I am positive that they shall get along here nicely. 
Irwin M. Shalter.

\section{CARTA DE LUIZ DE TOLEDO PIZA AO EMBAIXADOR BERLE JÚNIOR - MLb 3.2.00435 CX 9 (CEDAE/IEL)}

Excelentissimo Senhor Embaixador:

(...)

Tenho a honra de submeter a Vossa Excelência, por cópia anexa, a carta que tomarei a liberdade de endereçar ao ilustre artista Walt Disney, sobre o nosso grande escritor Monteiro Lobato, cuja inteligência tem sido posta, invariavelmente, a serviço da maior compreensão e amizade dos nossos dois povos.

É que Walt Disney e Monteiro Lobato são bem Artistas da América. O primeiro, com os seus personagens maravilhosos, compondo um cinema próprio; o segundo, com as figuras infantís, que enchem toda uma coleção magnífica da nossa literatura, têm contribuido, eficazmente, para a alegria e ventura das crianças do continente novo, principalmente para as do Brasil, no seio das quais gozam ambos de igual afeto e popularidade.

A identificação perfeita dessas duas lídimas e expressões da arte americana, seria certamente intercambio do mais alto valor cultural e bem fundamentada razão de manutenção e fortalecimento da estima e aprêço existente entre brasileiros e norteamericanos.

E, esta minha iniciativa, estaria, não há dúvida, fadada a todo êxito, se, acaso, tivesse a ilustrá-la algumas palavras de Vossa Excelência, Senhor Embaixador, dirigidas a Walt Disney sôbre a significação em nossas letras de Monteiro Lobato e sôbre o que êlo [sic] tem feito para difundir, entre nós, o pensamento cultural da Pátria de Vossa Excelência, como o maior dos nossos tradutores de livros da Norte-América, para o idioma português.

Uma apresentação, assim, feita por Vossa Excelência, dissiparia quaisquer dúvidas porventura existentes em Walt Disney e constituiria uma distinção à qual ficariam todos os brasileiros agradecidos para todo o sempre.

Para mim, pessoalmente, seria um momento inesquecivel na minha vida, se recebesse em minha residência, à rua Grão Pará n.128, c/8, - Engenho Novo - nesta capital, qualquer atenção que se dignasse Vossa Excelência de dar a êste meu pedido.

Aproveito-me desta oportunidade para apresentar a Vossa Excelência as expressões da minha mais alta consideração e respeito,

Rio de Janeiro, 28 de Maio de 1945

Luiz de Toledo Piza. 
Ao Excelentissimo Senhor Embaixador Berle Junior

American Embassy

\section{BILHETE DE PEDRO DE TOLEDO A MONTEIRO LOBATO - MLb 3.2.00354 CX 7 (CEDAE/IEL)}

Pedro de Toledo cumprimenta ao seu ilustre amigo e patricio, Monteiro Lobato e muito lhe agradece a remessa do seu interessante folheto - "How Henry Ford is regarded in Brazil" augurando-lhe um legítimo e merecido sucesso. Aproveita a oportunidade para felicital-o pela ultima série de artigos, publicados n“o Jornal”.

Rio 7 de Janeiro

1927

CARTÃO DE PEDRO DE TOLEDO A MONTEIRO LOBATO - MLb 3.2.00368 CX 8 (CEDAE/IEL)

S. Paulo 7 de Junho 1932

[papel com dizeres impressos:

GABINETE DO INTERVENTOR

$\mathrm{NO}$

ESTADO DE S. PAULO]

Prezado Dr. Monteiro Lobato

Não sei bem se já lhe agradeci a offerta de seu livro - "America" e especialmente á dedicatoria, com que me destinguiu.

Na duvida, é melhor repetir, como agora faço, os meus protestos de reconhecimento por ambas as coisas. Excusado é dizer-lhe que não mereço o titulo de glorioso paulista, que não passei de um jactum [? factus? incompreensível] minimo dos acontecimentos, que se realisaram, porque tinham de se realisar, quer eu quisesse, quer não.

Em todo caso, como o destino me deu um lugar na frente, mais uma vez obrigado.

Com a mais alta estima e admiração sou seu

Am. ${ }^{o}$ e alt. ${ }^{o}$ cr. $^{o}$ [incompreensível]

Pedro de Toledo 
RINALDO DE BIASI - 26/08/1945 (RAS - DML - CP/CA, CX 4, P2 - 046)

Rio de Janeiro, 26 de agôsto de 1945

Dr. Monteiro Lobato,

Tomo a liberdade de dirigir-me a V.S. porque muito o admiro; se outros motivos não existissem para ser seu admirador, bastava o fato de orgulhar-me de seu seu [sic] conterrâneo, pois também nasci em Taubaté.

Sempre o admirei principalmente pelo seu idealismo; pela sua vontade em querer um Brasil mais progressista e de mais projeção; pelas suas campanhas em prol da siderurgia e do petróleo.

O que V.S. escreveu em "América” e nos prefácios das obras de Ford muito me entusiasmou.

Agora queria que V.S. me esclarecesse sôbre um ponto para o qual não tenho elementos para explicar e justificar.

V.S. viveu alguns anos nos Estados Unidos; tornou-se admirador daquela grande Nação; publicou "América" que é um admirável documentário sôbre aquele País.

Pois bem, V.S. vem de filiar-se ao Partido Comunista, isto é, pensa com aqueles que desejam mudar as nossas instituições, inspiradas na democracia anglonorte-americana, pelas que atualmente vigoram na U.R.S.S.

Então V.S. acha que o regime soviético é superior ao norteamericano?

Então V.S. acha que os problemas políticos, administrativos e sociais brasileiros não podem ser resolvidos com instituições similares às norteamericanas, havendo necessidade da adoção do comunismo?

Finalmente, não posso compreender como é partidário do comunismo sendo grande admirador da Nação Norte-Americana.

Termino, informando a V.S. que sou católico praticante, nunca fui integralista e sou anti-comunista.

Sou modesto escriturário do Banco do Brasil S.A., há 11 anos, e tenho 30 anos.

Ficarei sumamente grato a V.S. se se dignar de responder a esta missiva.

\section{Rinaldo de Biasi}

Rua Machado de Assis 45 
$\operatorname{apart}^{\mathrm{O}} 302$ -

LUCIEN BOURRET - s/d (RAS - DML - CP/CA, CX 4, P2 - 050)

[etiqueta colada na parte de cima da página com os dizeres

"Francês prático - Literatura - Historia

LUCIEN BOURRET

professor

Fone 5-8073 554, RUA TUCUNA”]

Monsieur Monteiro Lobato

A la suite de diverses expériences, j'avais décidé de ne jamais plus ouvrir un livre d'auteur Brésilien.

Puis après avoir lu quelques-unes de vos traduction [sic], le désir m'est venu de faire excepction pour vous.

Bien que mon humble opinion n'ajoutera certainement rien à votre gloire, permettez-moi de vous dire que la lecture de: $\mathrm{O}$ choque das raças, m'a causé un vif plaisir.

Je crois que ce livre excellent serait apprécié même à Paris, la ville où j'ai vu le jour (je suis né à 8 1/2 du matin parait-il)

Veuillez agréer Monsieur, l'assurance de ma parfaite consideration.

Bourret

GILSON MAURITY SANTOS - s/d (RAS - DML - CP/CA, CX 4, P2 - 053)

Meu caro M.L.

Como me é grato chamar-lhe assim! E quanto sinto que V. me é querido!

De certo $\mathrm{V}$. nunca me viu. O que não posso dizer é que V. não me conheça. Ha pouco menos de 10 anos eu queria andar de braços com o seu Pedrinho, a Emilia, o bando todo. 
Quis e pedi.

Respondeu-me o Visconde - e com que camaradagem! Entusiasmei. Escrevi outra vez e dessa V.me respondeu. Não me lembro de ter insistido. Sempre fui muito timido e receei importuna-lo.

Mas o sitio do Picapau Amarelo continuou morando em meu coração. E como!

Reli inúmeras vezes todos os livros. E cada vez(não sei como conseguia fazer isso) abstinha-me de toda a ideia preconcebida e entrava no volume com a mesma delicia da prelibação duma historia do Monteiro Lobato.Tal qual da primeira vez.

Só um ano saiu um livro que me enganou - O ESCANDALO DO PETROLEO.

-“Oh delicia! murmurava eu no bonde, apertando o livro contra o peito com os dois braços como se tivesse de protege-lo do mundo. A imaginação dava saltos, cambalhotas, a fantasiar quem de novo lá aparecia, que fariam os meus velhos amigos do sitio. Tive de fazer uma força enorme para não abrir o pacote ali mesmo no bonde. Consegui.Não abri.

Só em casa comecei a ler. Poucas paginas bastaram para me mudar as ideias.

- "Mas", disse comigo mesmo, "não faz mal. Estou ficando moço e preciso ler coisas serias. E, demais, o livro é do Lobato."

Devo dizer que as dez paginas seguintes me fizeram tropeçar e fechar o livro entristecido. Não compreendia nada.

Só mais tarde vim a le-lo todo, e com que entusiasmo e revolta! Mas isto não devia ser escrito.

Com seus livros na cabeça, quasi decorados, eu fiz os meus primeiros alicerces literarios. Deles me vieram a imaginação enorme que me põe hoje a olhar para o chão, sem ver, a cismar em coisas e gatos e historias que eu invento. E dali veio a vontade de ler e o entusiasmo que tenho pelos livros. E o carinho com que os trato. E por fim, abrasante, violentissima, veio a loucura que tenho de escrever.

Mais diretamente de V., da clareza do seu estilo, do que das suas criaturas, partiu esse raio que me excita a imaginação e o desejo de fixa-la no papel.

É logico que muita gente tem influido em minha formação e particularmente em meus pendores para a literatura, para esse amor enorme que tenho para os livros. Mas V. foi a base. Foi e é a parte fundamental desse edificio que tem pouco mais de um andar(se é que já tem um andar...)

Creio mesmo que essas primeiras anunciações de principios filosoficos, muito raros de aparecerem numa idade como a minha (tenho 20 anos agora) partem de V. 
Aquela mania analitica da Emilia possuiu-me até hoje. Aquela bondade de dona Benta não digo que eu a possua, mas dá-me vontade de ser tambem assim tolertante e bom. O Pedrinho, o visconde, Narizinho, em todos eles (até no Rabicó) eu vejo personificação de pedaços do meu eu...

É isso tudo, meu amigo, que me faz escrever para V. É esse sentimento de gratidão e amizade e principalmente de admiração

É também para lembrar que daquela meninada cheia de entusiasmo pelos seus escritos, pelo menos um (mas tenho a certeza de que existem muitos outros assim) nunca o esqueceu e guarda com carinho a lembrança do Monteiro Lobato. Começam agora a pensar e agir os seus primeiros filhos literários (vamos dizer assim). Voce começa a ver os primeiros resultadosa do seu trabalho magnífico,edificante.

Bem, vou acabar aqui. Não sei se V. está não está cansado. Não sei se se aborrece com cartas. Não acredito e por isso escrevi. E escreverei mais. Contarei muiito de mim,Mas...eu ainda não disse quem sou...Lá vai:

Gilson Maurity Santos

R. Laranjeiras, 433

[Nota: Lobato prometeu, em visitas a escolas infantis em 1934, os livros Quindim no Paiz da Matematica e Emilia no Paiz da Historia do Brasil]

DORA SANTORO - 04/05/35 (RAS - DML - CP/CA, CX1 - P02 - 07)

Sr. Monteiro Lobato.

Saudações.

(...) Eu penso mesmo que a nossa professora tambem gosta de ler os seus livros, porque ficou encantada quando soube que eu já os conheço todos.

Ao contar este fato em casa, uma das minhas irmãs informou-me de que o Sr. não escreve só para crianças.

É pena!

$(\ldots)$

Dizendo-lhe muito obrigada pela atenção, abraça-o

Dora Santoro.

Aluna do $1^{\circ}$ ano da 
E.I.S. Orsina da Fonseca.

MARINA PINA DE SOUZA - 25/11/36 (RAS - DML - CP/CA, CX 1, P01 - 53)

S. Paulo-25-11-1936.

Snr. Monteiro Lobato

$(\ldots)$

Meu primo, José Bonifacio de Souza Amaral, por intermedio do qual recebi o livro ["D. Quixote das crianças"], disse-me que o senhor, iria escrever agora "Emilia tira petróleo". Estou ansiosa para que saia logo, pois quero aprender como se tira. Deve ser muito interessante, como todos os outros livros que tem escripto.

(...)

Da sua admiradora

Marina Piza de Souza.

IÊDA AUGUSTA RIBEIRO MACIEL - 04/07/36 (RAS - DML - CP/CA, CX 1, P01 45)

Recife, 4 de julho de 1936.

Prezado amigo Monteiro Lobato

$(\ldots)$

Tenho muita vontade de conhecê-lo pessôalmente. Já o conheço pelo retrato através dos jornais, quando o sr. esteve em Maceió e falou sobre o petrolio [sic] de Riacho Dôce. Fiquei muito alegre. Somos todos alagôanos, exceto o caçula que é pernambucano da gema.

(...)

Adeus, aceite um abraço apertado da leitora que o admira muito e muito.

Iêda Augusta Ribeiro Maciel. 12 anos.

Meu endereço: Rua Barão de São Borja nº 192. Recife.Permambuco.

Responda-me. 


\section{Rio-14-7-1934}

Caro amigo Monteiro Lobato:

(...)

E as minas de petroleo? Sera que o visconde já esta fazendo gasolina para a suzia de automoveis da Emilia?

Faço votos para sua felicidade e espero que me responda

Adeus lembranças a todos

Gilson Luiz Marnity Santos

JOSÉ DE TOLEDO PIZA - 28/09/36 (RAS - DML - CP/CA, CX 1, P01-56)

Santa Ernestina - 28/9-936.

Snr. Monteiro Lobato.

Saudações

Os meus votos de milhares de felicidades é o que desejo.

Venho hoje por meio desta enviar ao Snr. ao Dr. Osman Loureiro e Edson de Camargo, os meus sinceros parabens, pela grande victoria, que acabam de conquistar.

É como diz o dictado, que em cada nação ha a pessôa má e ruim, e na nóssa infeliz Patria, alem de existir o brasileiro, bom e ruim, ha o inpatriota [sic]

Mas graças a Deus o Brasil encontrou, nessas grandes personagens, brasileiras, o seu grande amôr a Patria.

Desde o primeiro, gríto, pelo petroleo, é que venho acompanhando, o quanto custou ao Snrs. o sacrificio, para vêr jorrar, das nossas imensidões terras, o liquido negro, a salvação economica, e o caminho de uma grande potencia.

Mas custou, o que custasse, a victoria está ganha

E com certeza, nessa hóra, essas grandes companhias, e os nossos maquiavelicos, vendidos brazileiros, estaria com uma cara de quem comeu e não gostou, por ver que a nossa cauza, a cauza do Brasil, a cauza dos Brasileiros, está ganha.

E dentro de mais alguns tempos, não precisaremos olhar com uma tristeza sem par, os milhares de caminhães que aqui passam, cheio de tambores, que é proveniente de uma nação, que pensa que a luz, do sól venho [sic] só para si, e éssas grandes companhias, 
com o auxilio dos brazileiros vendidos dentro de mais tempo, não receberão os seus 6 ou 7 milhões de libras ouro, os 500 ou 600 mil contos que são anualmente por cauza, do nosso grandioso governo, que nem siquer mexe uma, palha, para ajudar o nosso povo, que nos vende dia a dia para essas nações) [incompreensível: lisdoberenças?] do Mundo/

Eu digo em vóz, para essas nações, que não o somos, um povo, atrazados, não somos idiótas, somos vergonhósamente devido a o nosso governo, entregue as nações extrangeiras.

Mas chegou no final, estamos levantando, somos livres, não precisaremos, que eles nas veia [sic] ensinar.

Tem que chegar o dia do Trigo, o dia do Frigorifico, o dia da eletricidade, mas essas grandes economias, pertencem a outros brazileiros, os que tem amôr a nossa Patria.

Os que os Snrs., fizeram e mais outros, não tem mais direito de intervir, fizeram, uma grande ajuda a nossa Nação.

O que eu poderei fazer, será dado o meu apoio.

menino José de Toledo Piza

N.B. entre o petroleo e o Trigo - um milhão de canto [sic] que poderia ficar aqui dentro. 